Supporting Information

\title{
Asymmetric Allylation/RCM-Mediated Synthesis of Fluorinated Benzo-fused Bicyclic Homoallylic Amines as Dihydronaphthalene Derivatives
}

Daniel M. Sedgwick, ${ }^{\dagger}$ Pablo Barrio,${ }^{\dagger}$ Antonio Simón, ${ }^{\dagger}$ Raquel Román, ${ }^{*}$ Santos Fustero* ${ }^{\dagger+}$

Departamento de Química Orgánica, Universidad de Valencia, E-46100 Burjassot, Spain.

Laboratorio de Moléculas Orgánicas, Centro de Investigación Príncipe Felipe, E-46012 Valencia, Spain santos.fustero@uv.es, raquel.roman@uv.es

Content:

page

I. ${ }^{1} \mathrm{H},{ }^{13} \mathrm{C}$ and ${ }^{19} \mathrm{~F}$ NMR spectra of all new compounds.

II. ${ }^{1} \mathrm{H}$ of known products 156

III. HPLC spectra 160 


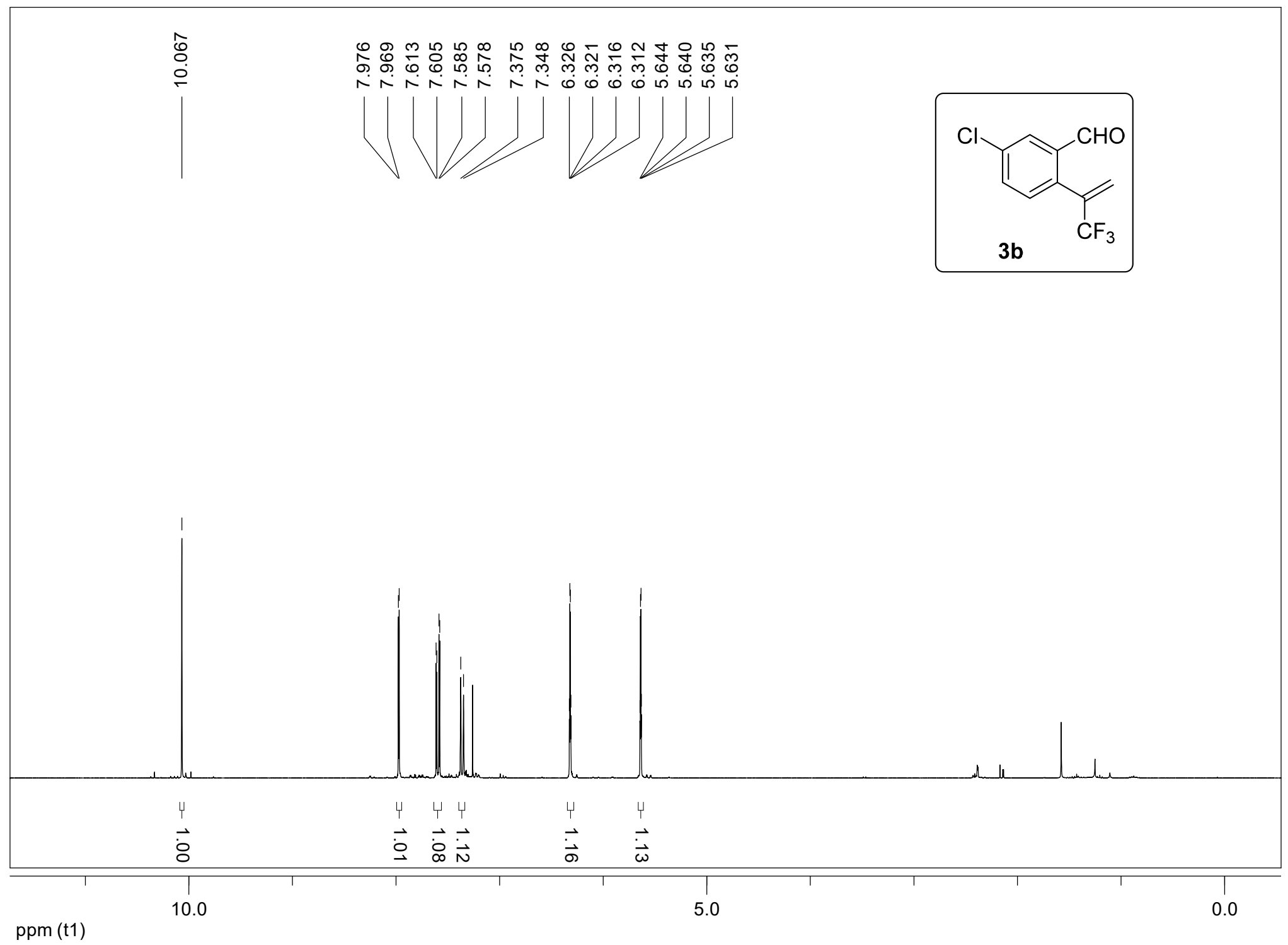




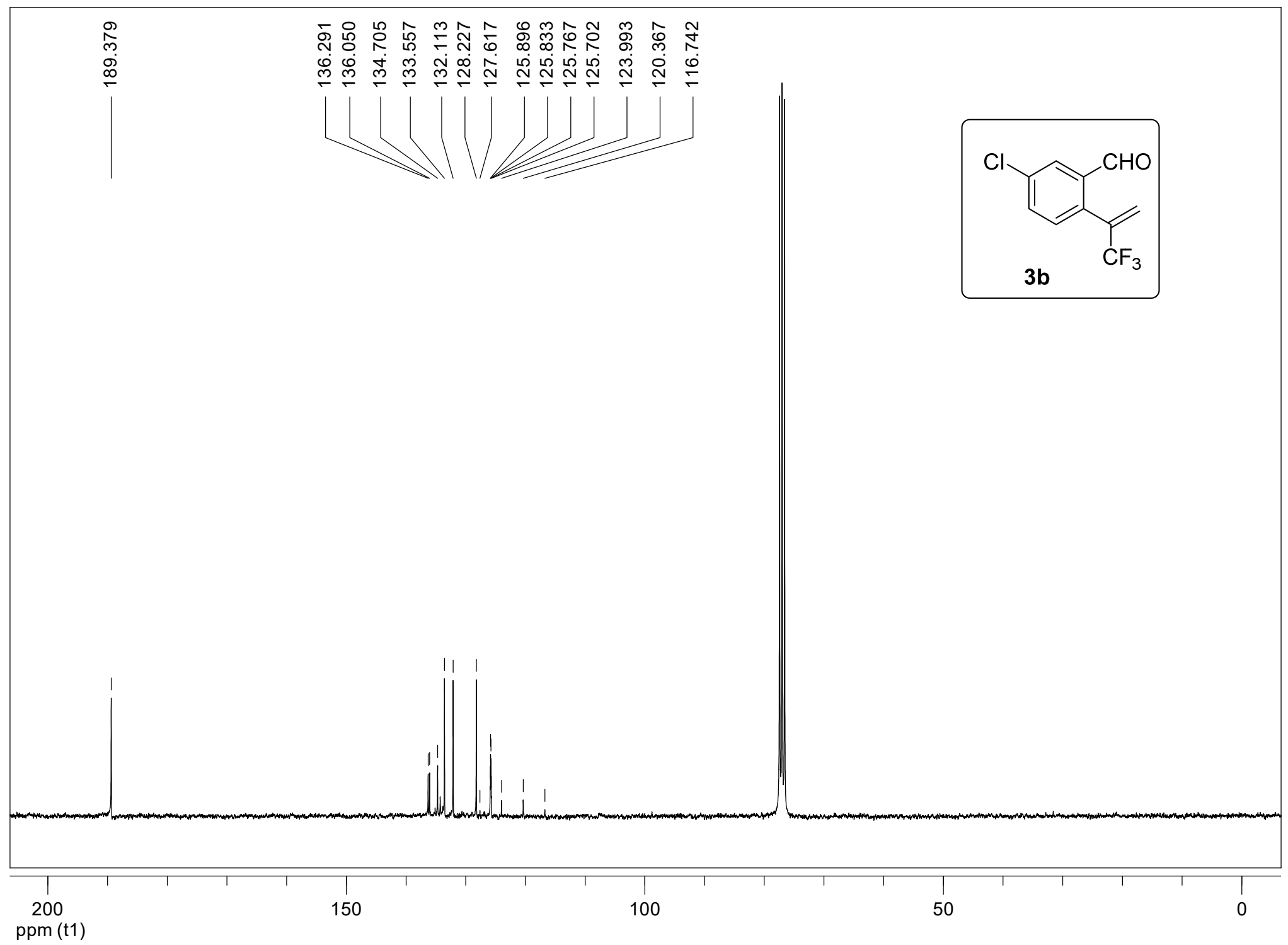




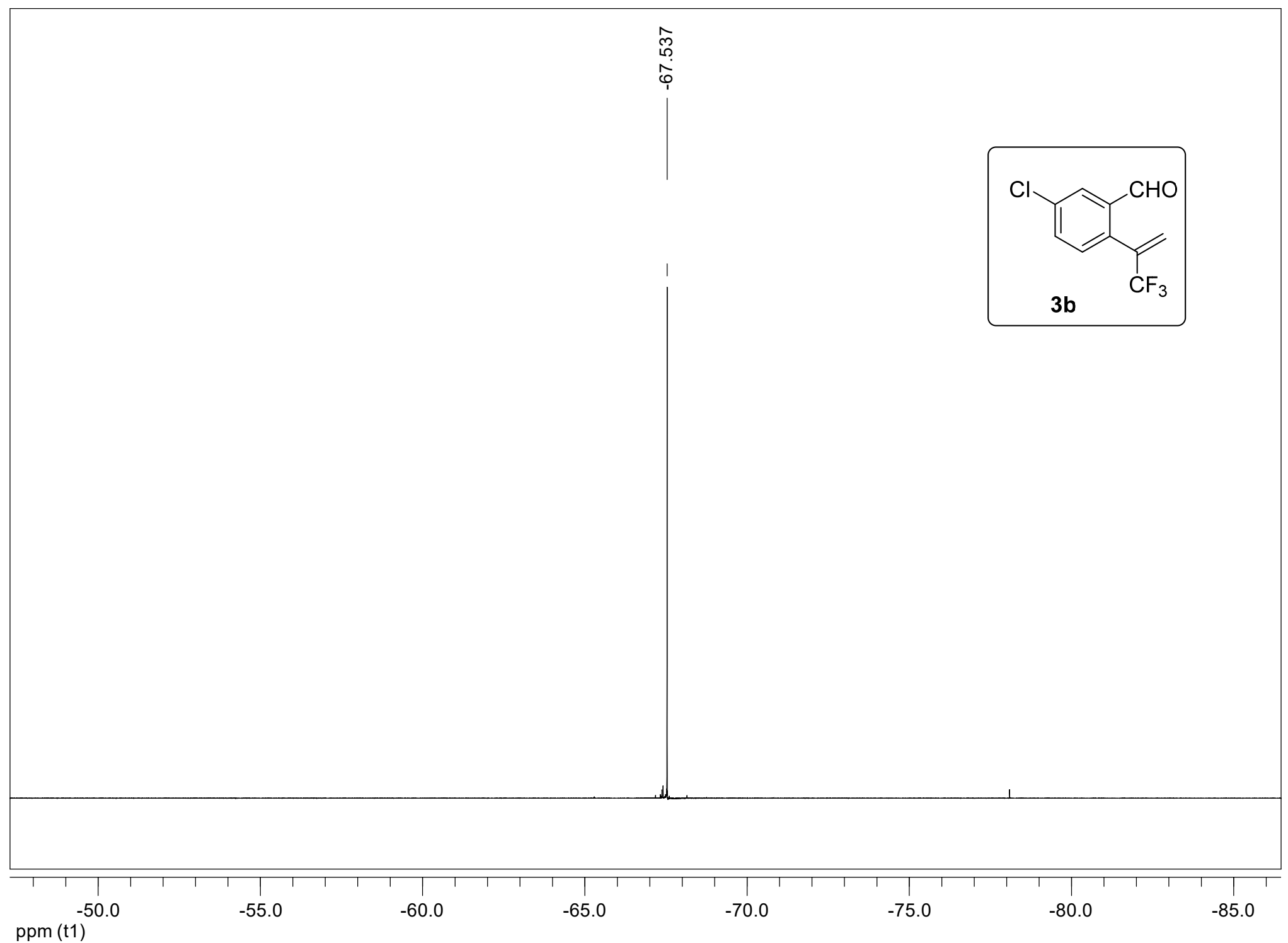




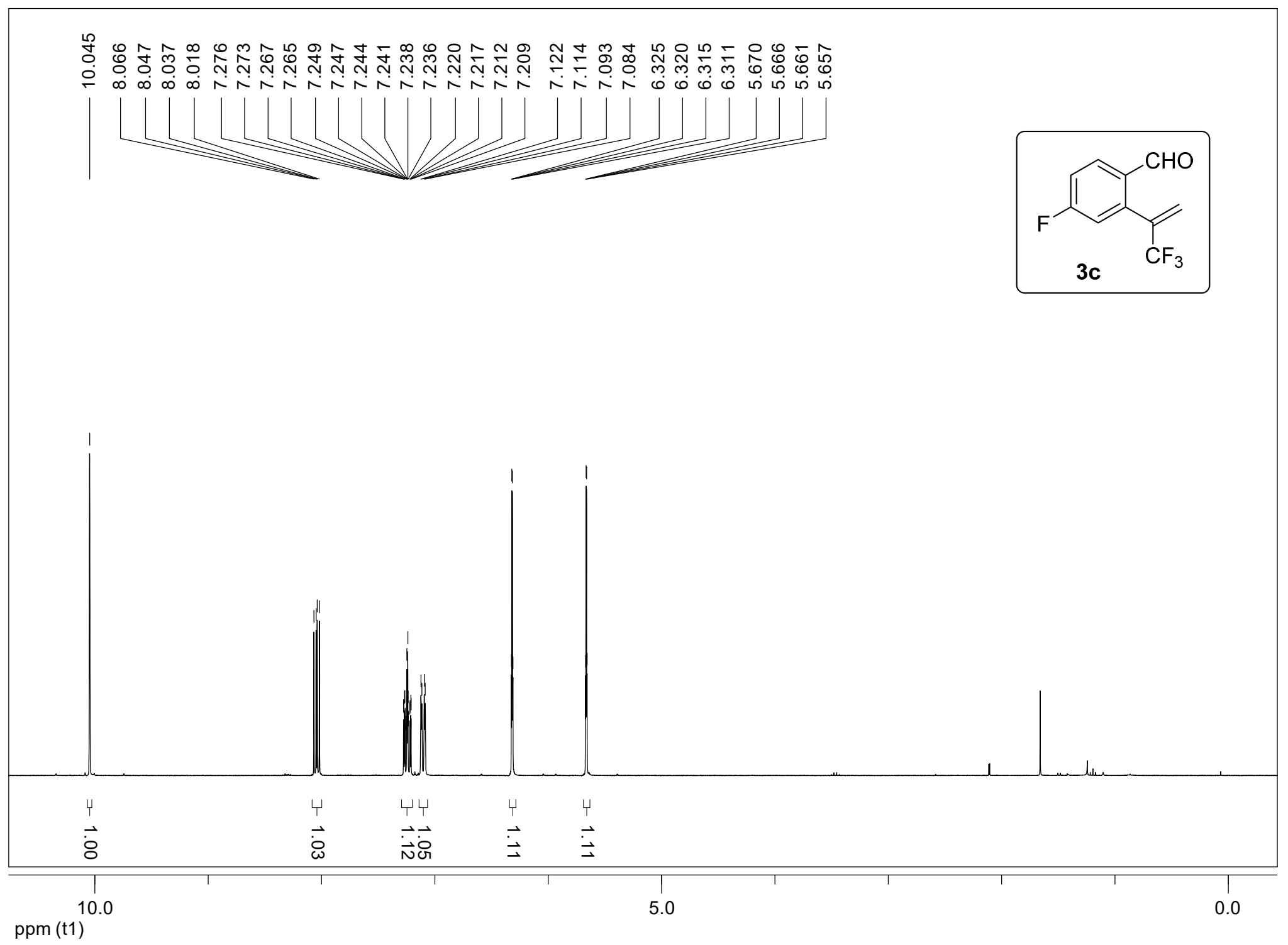




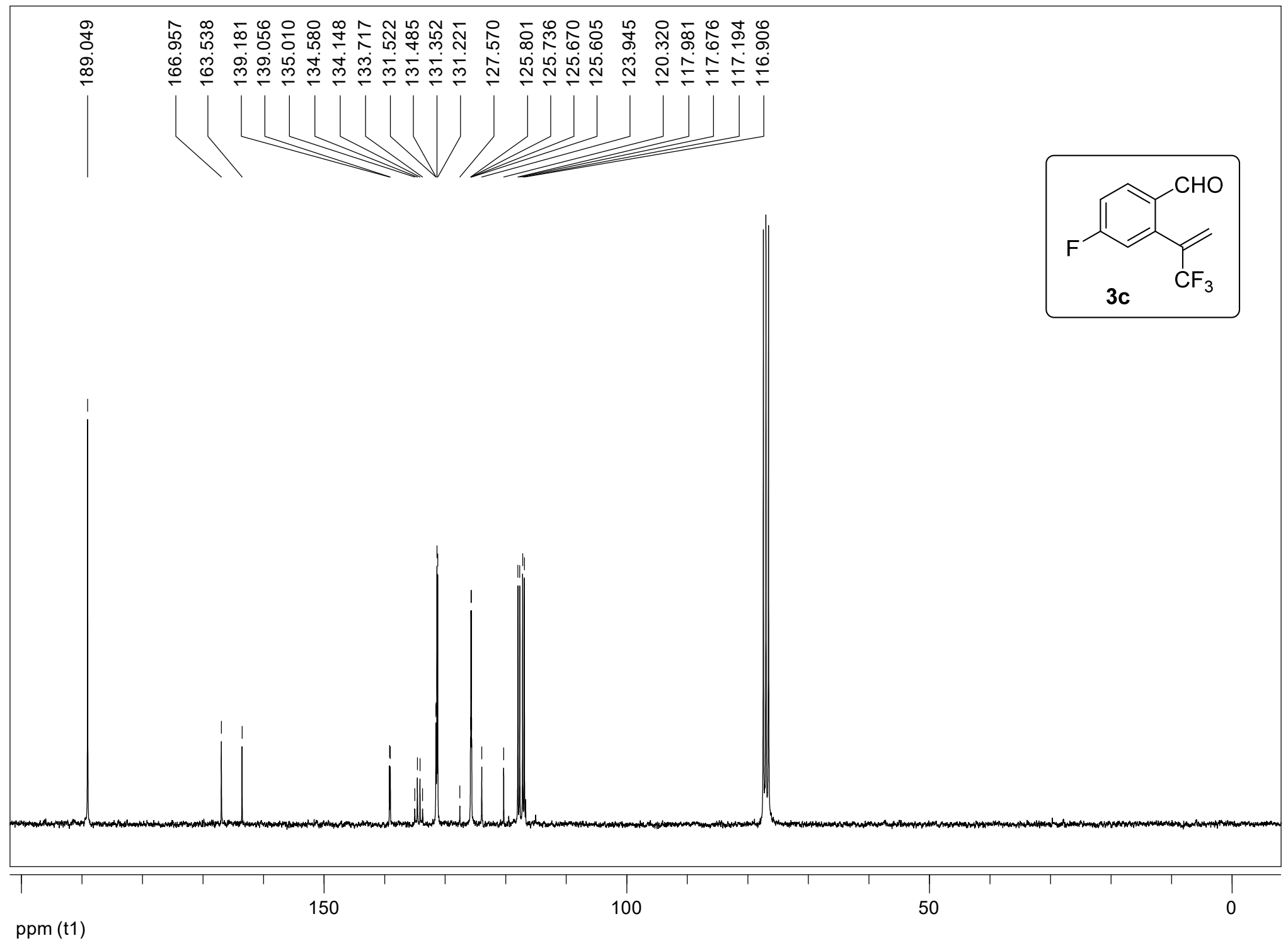




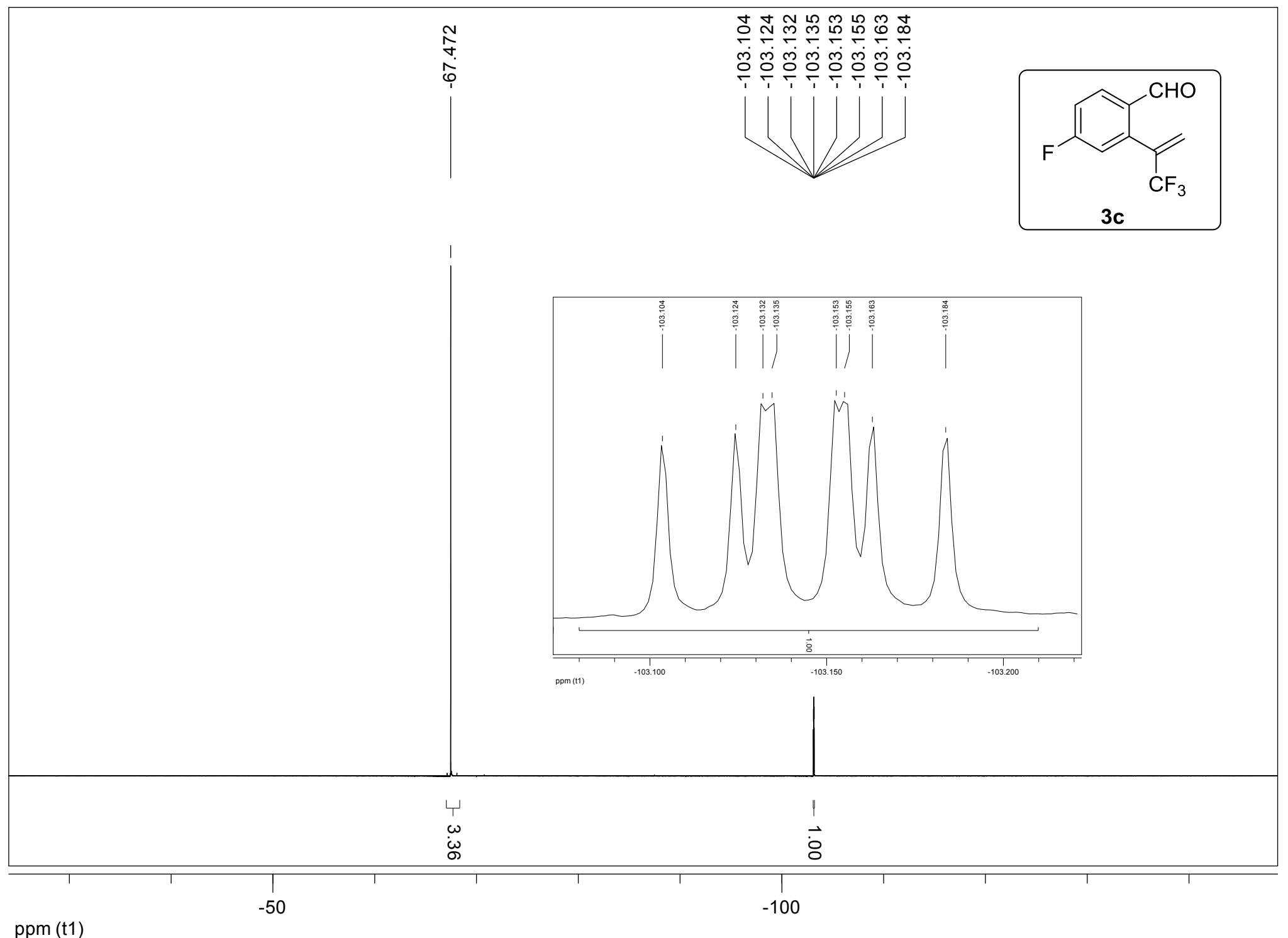




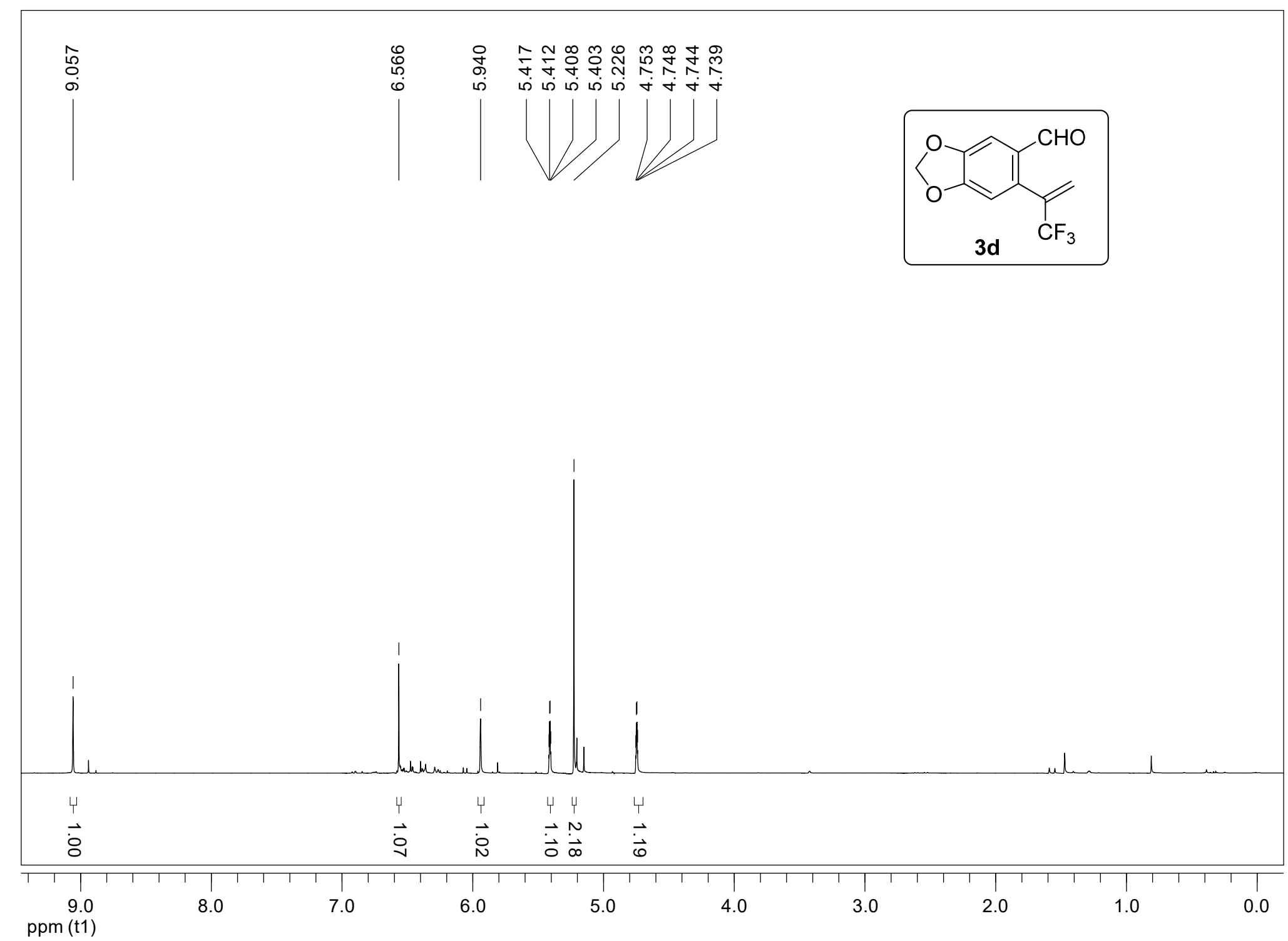




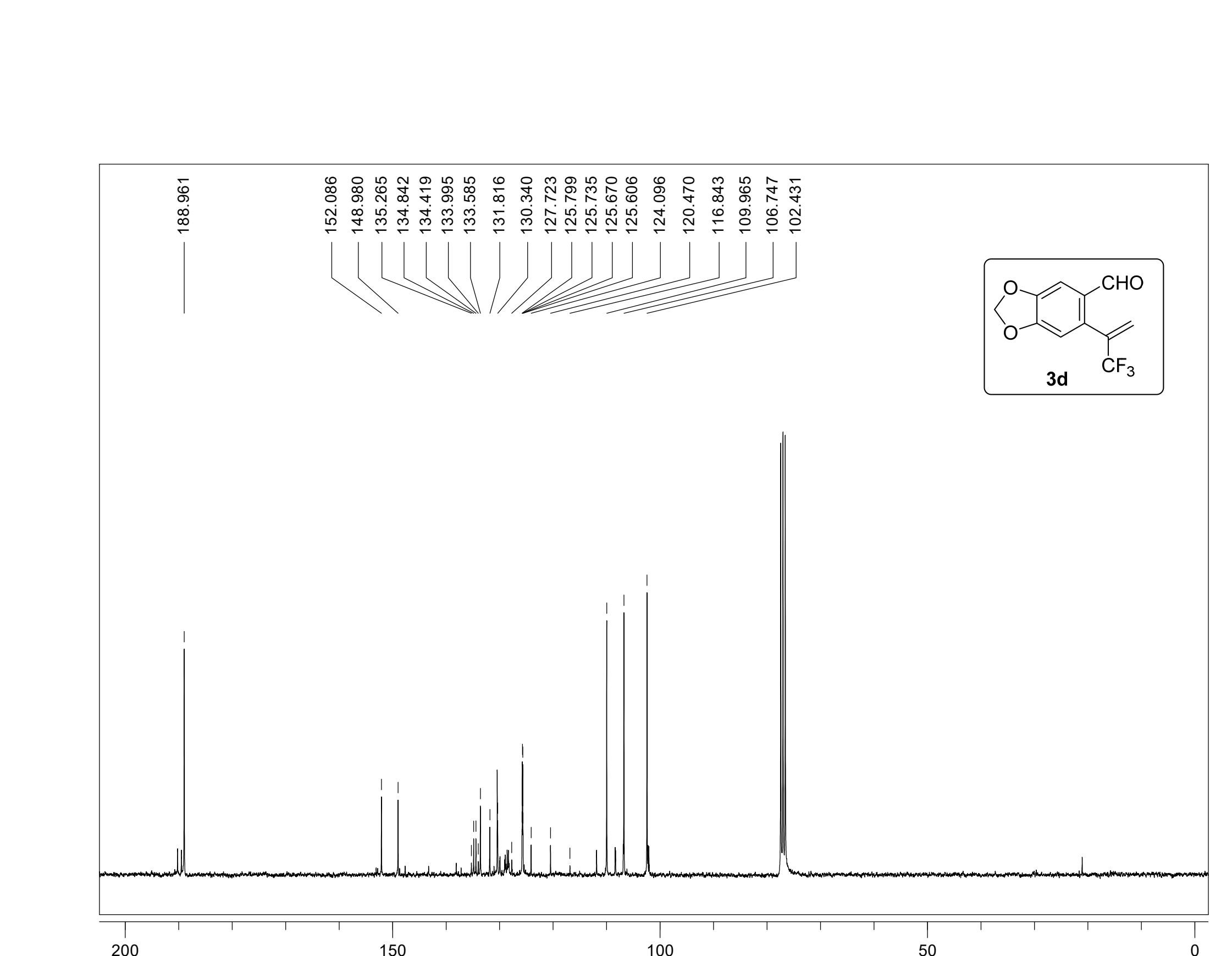




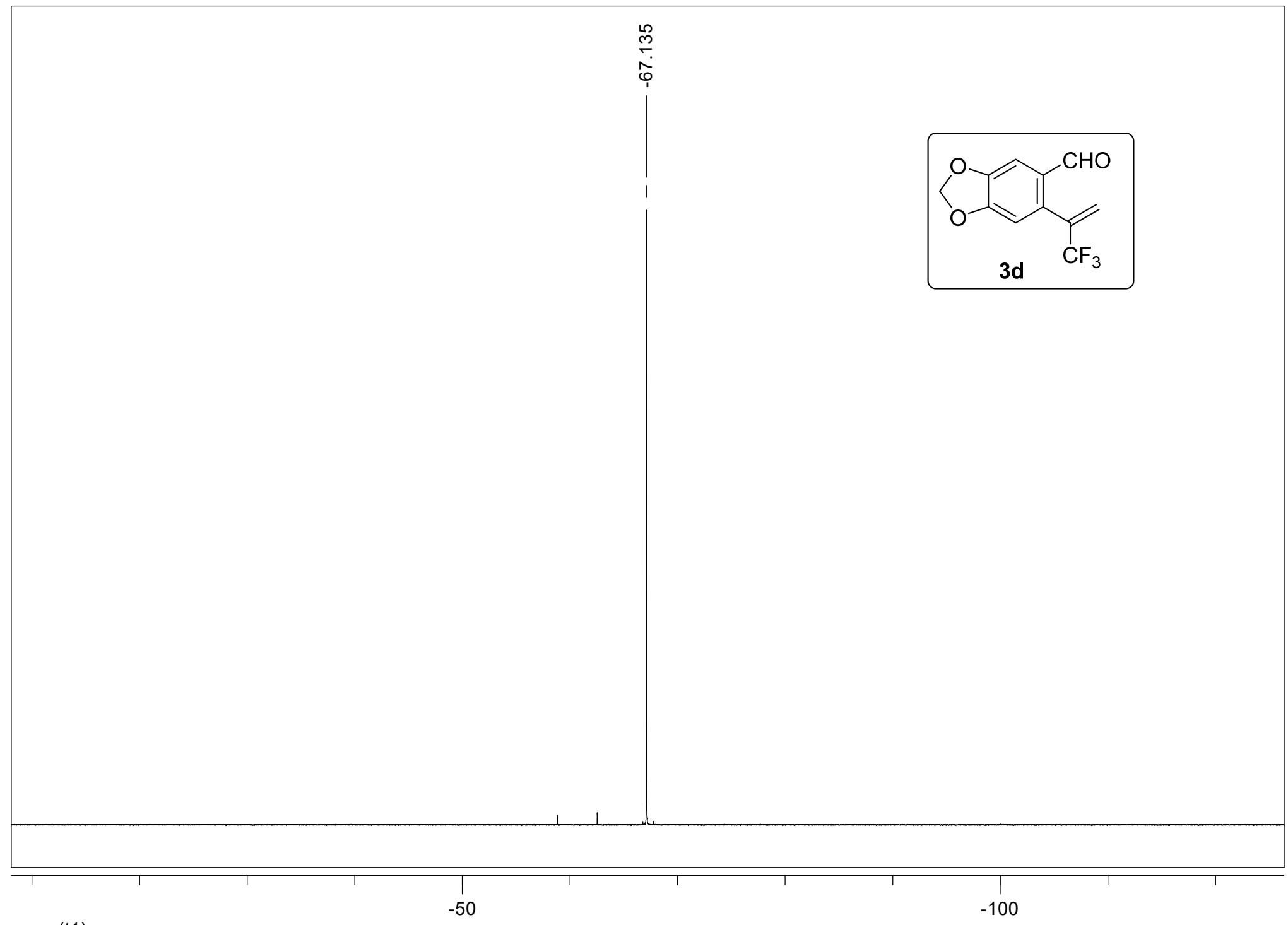

ppm (t1) 


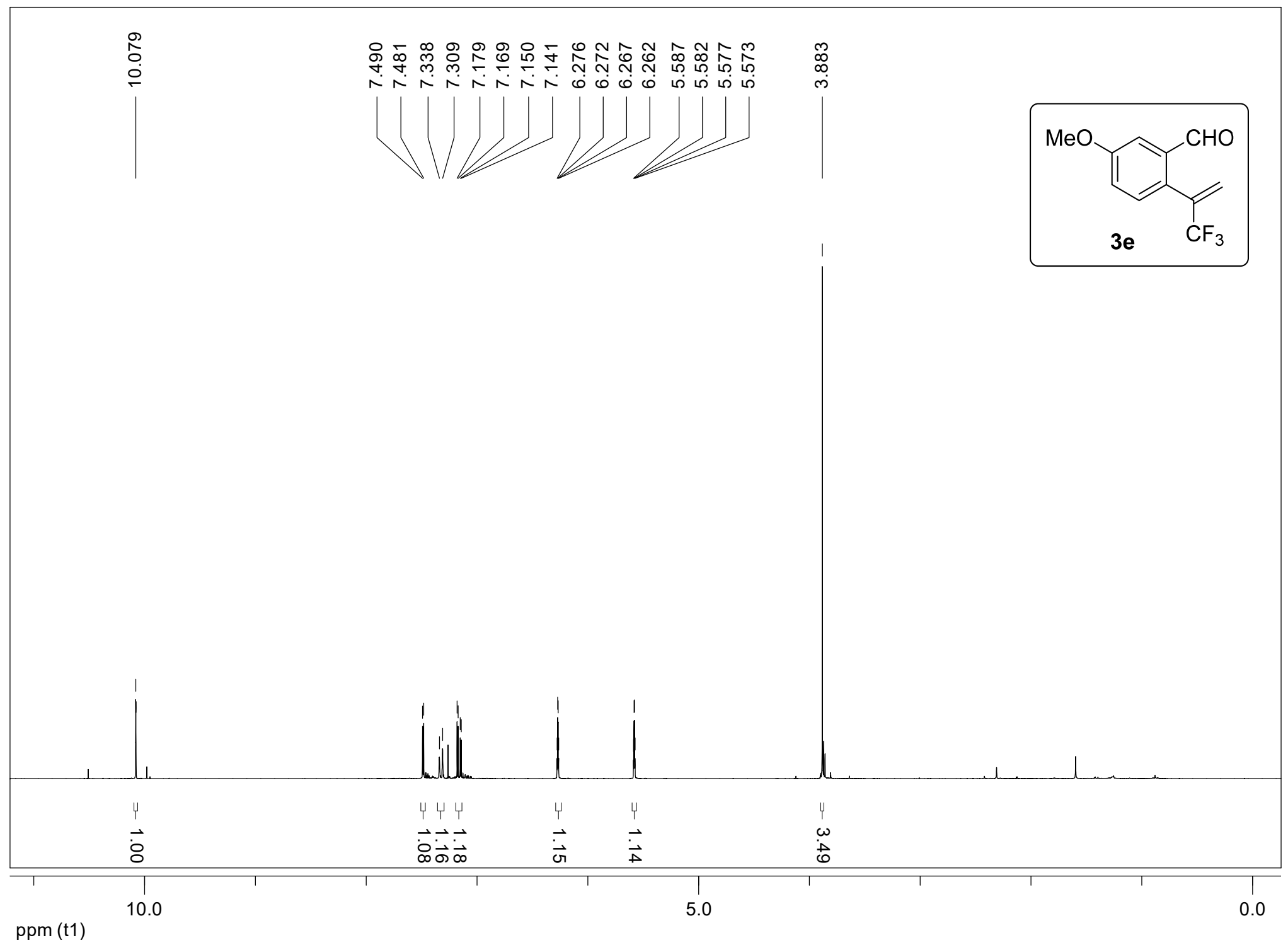




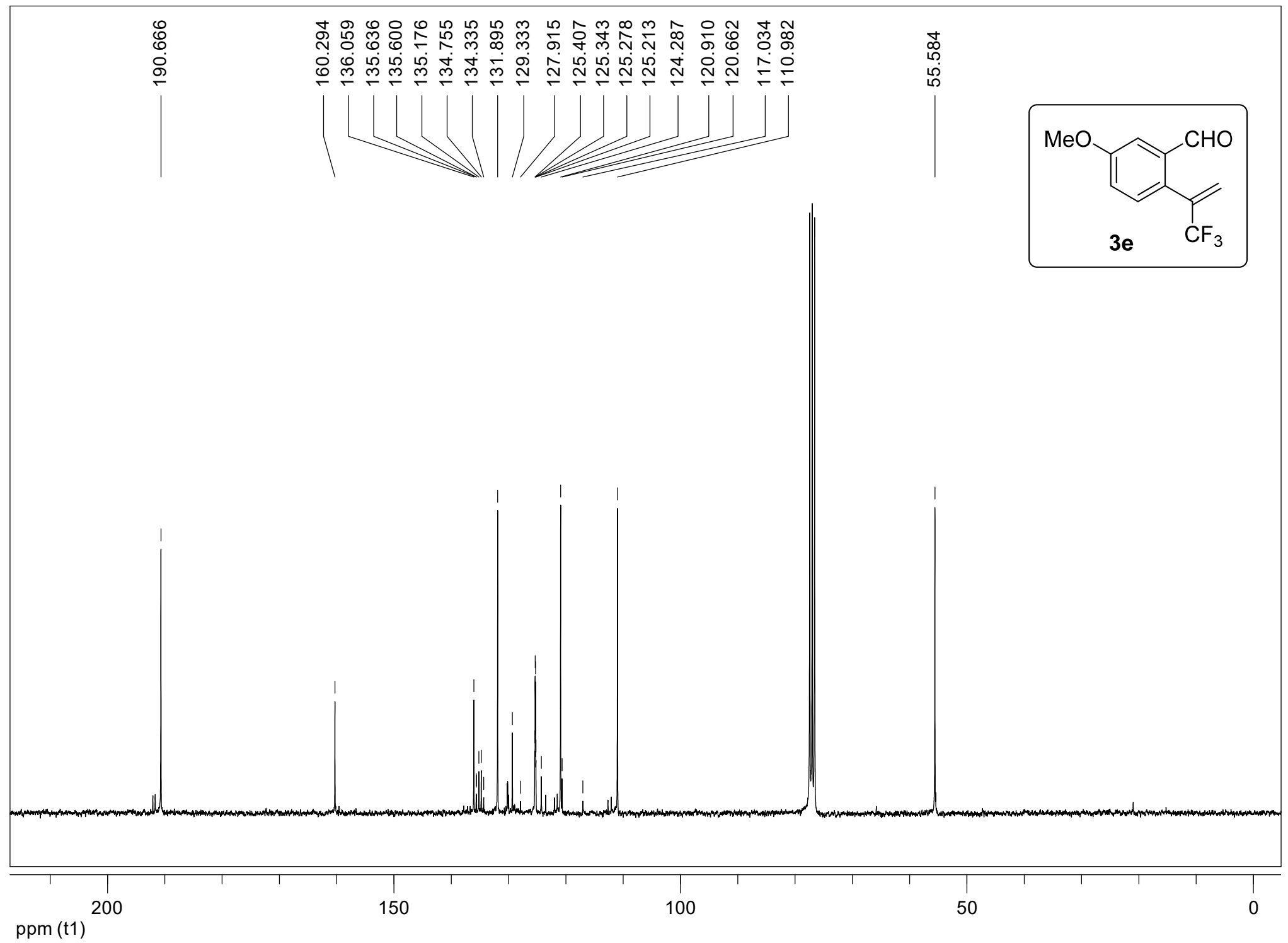




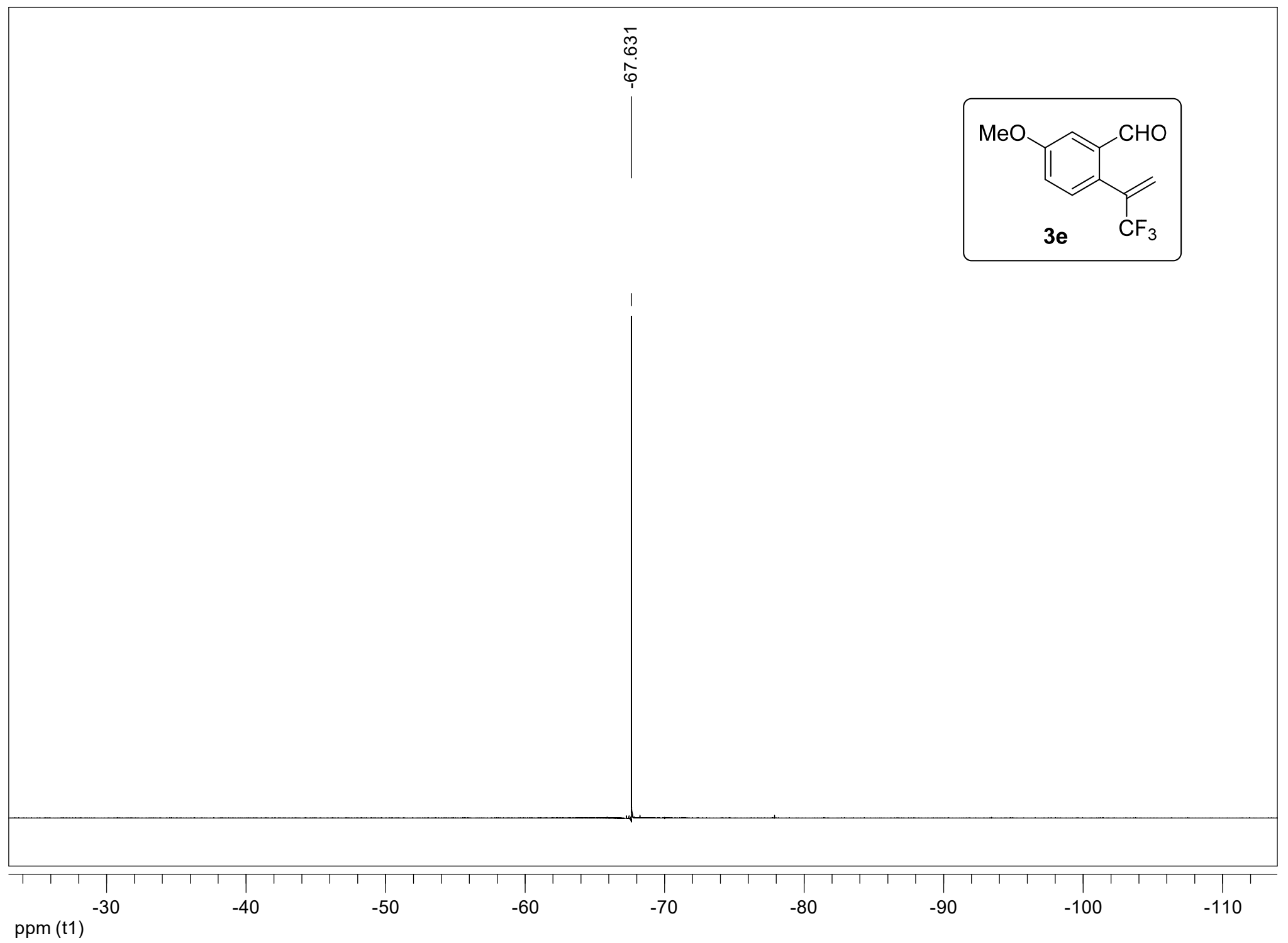




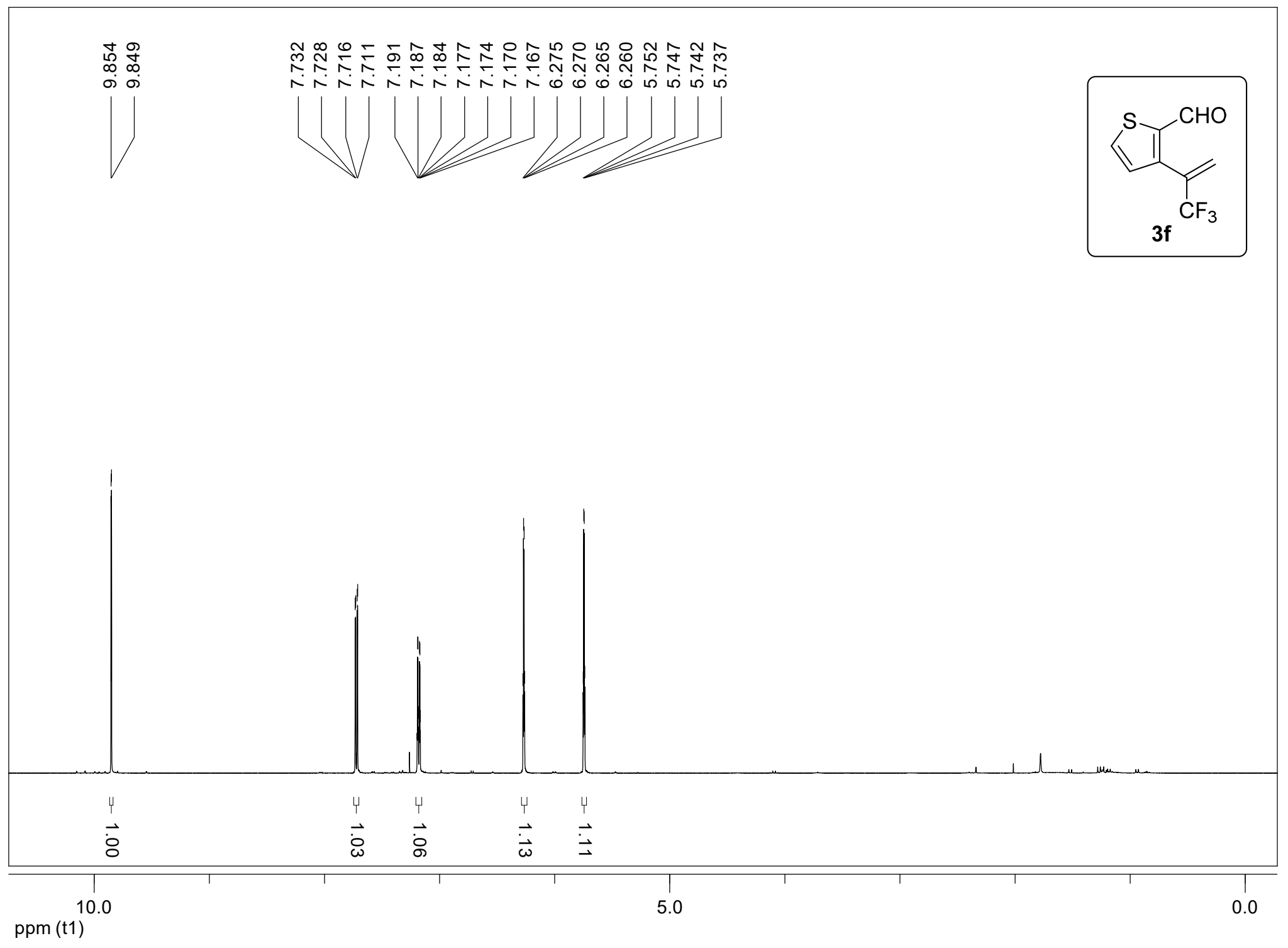




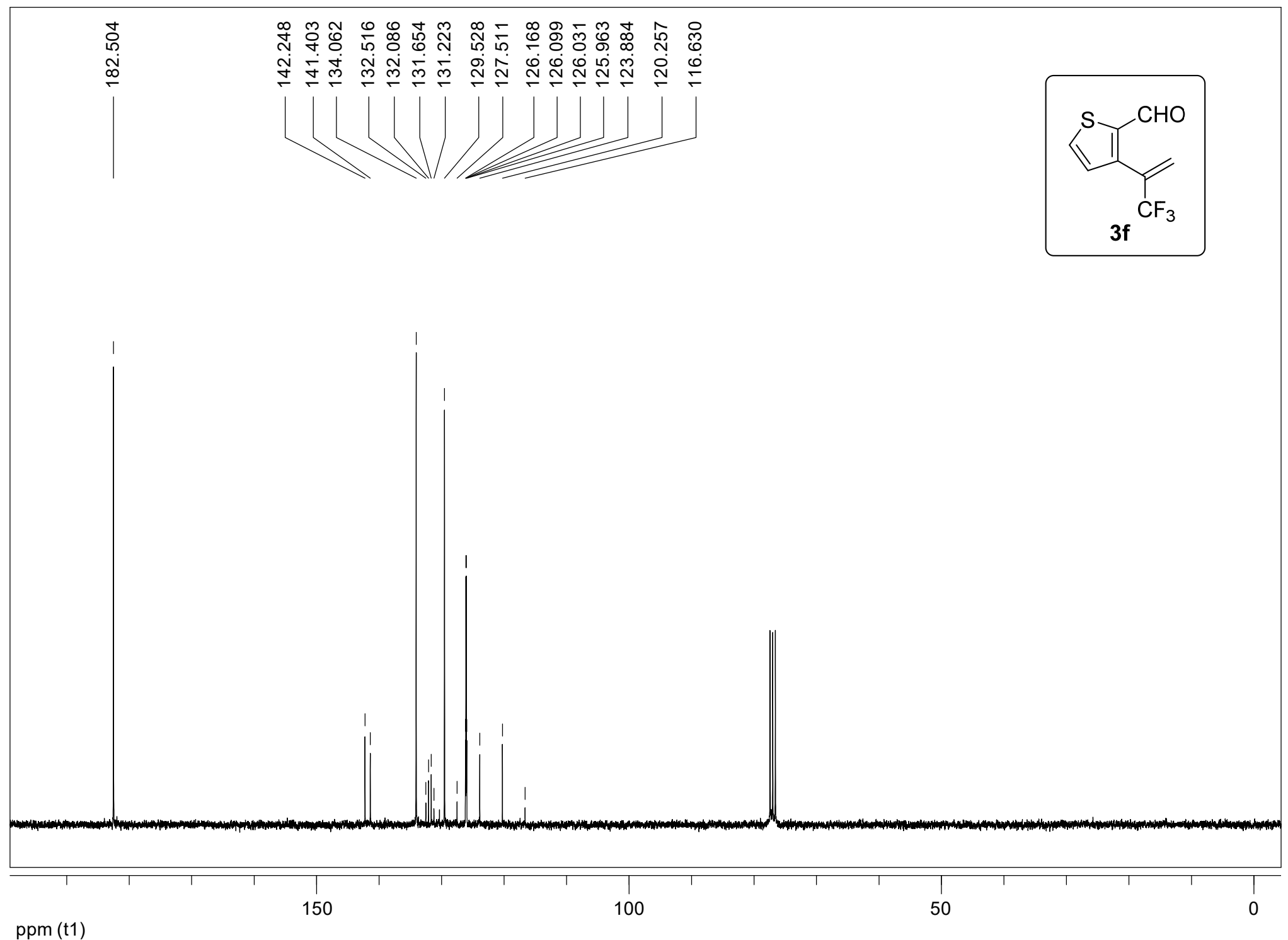




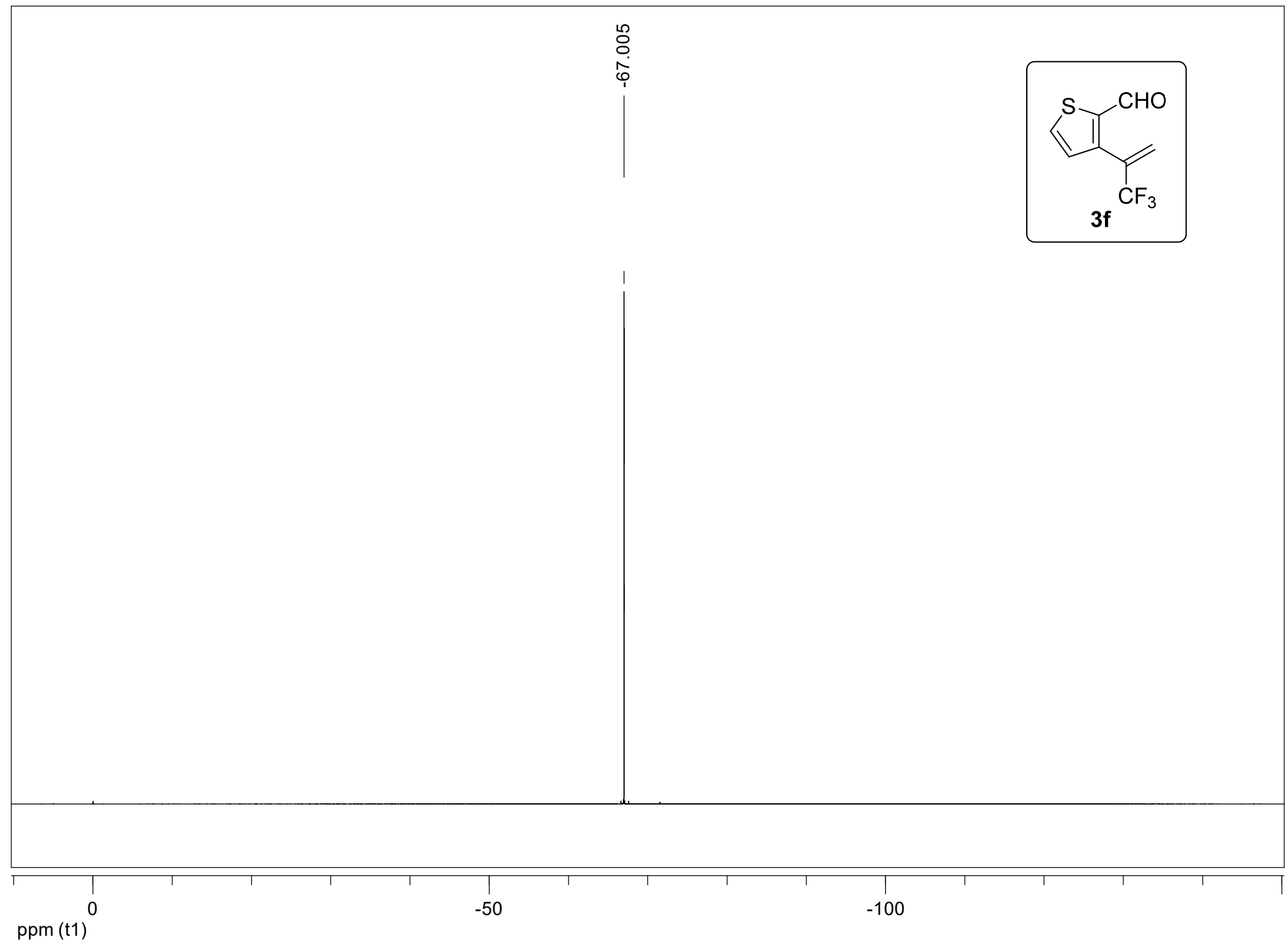




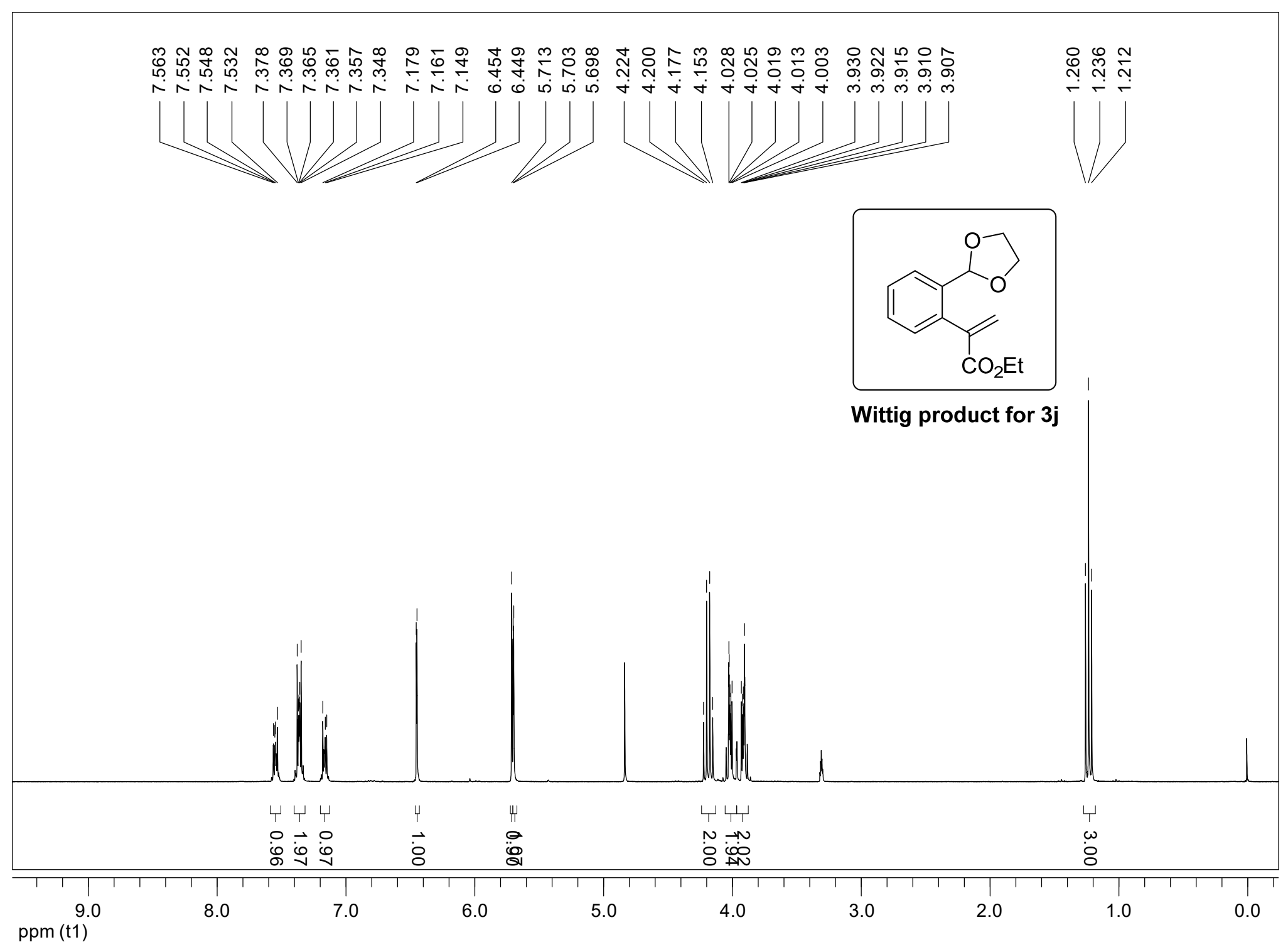




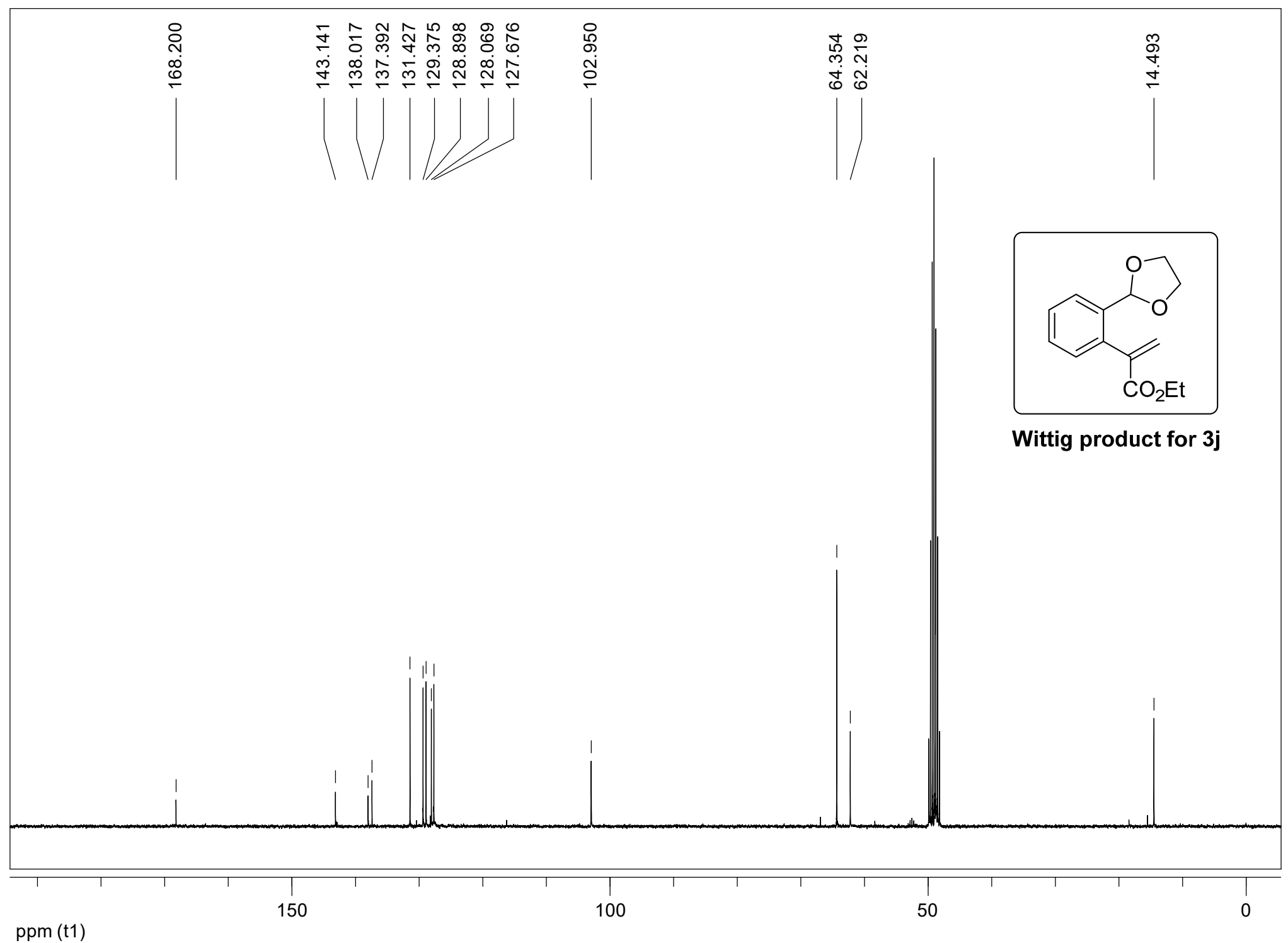




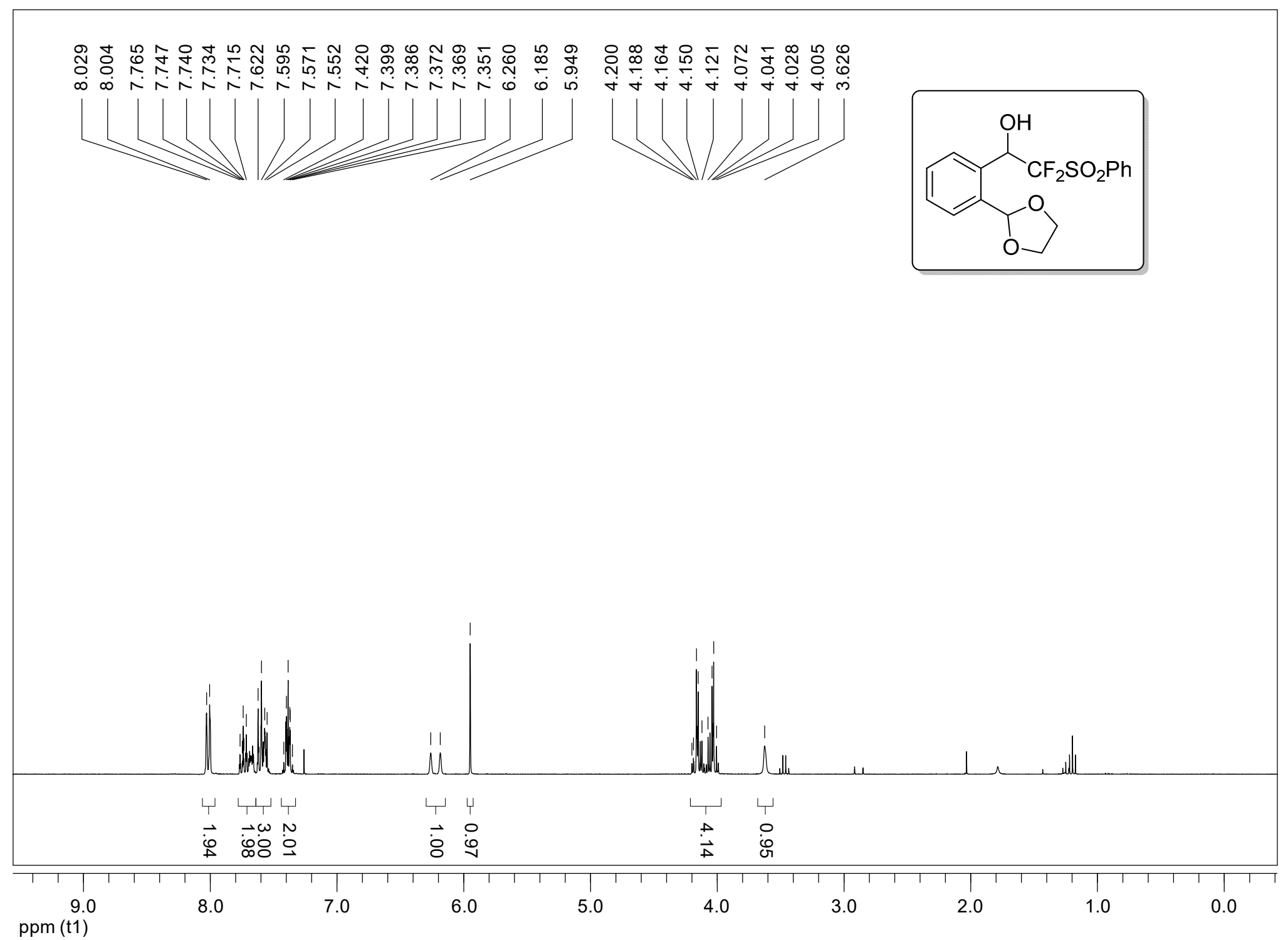




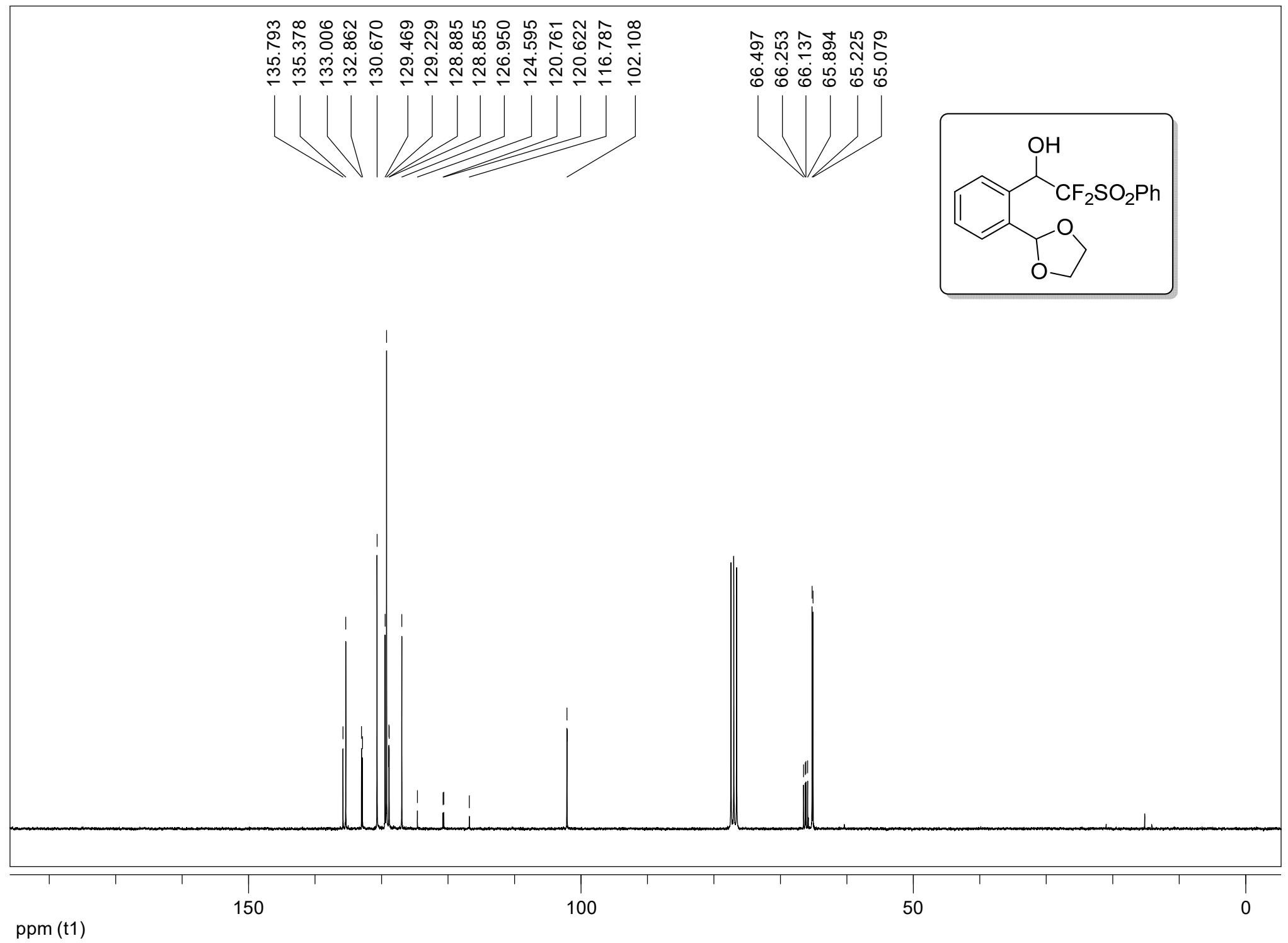




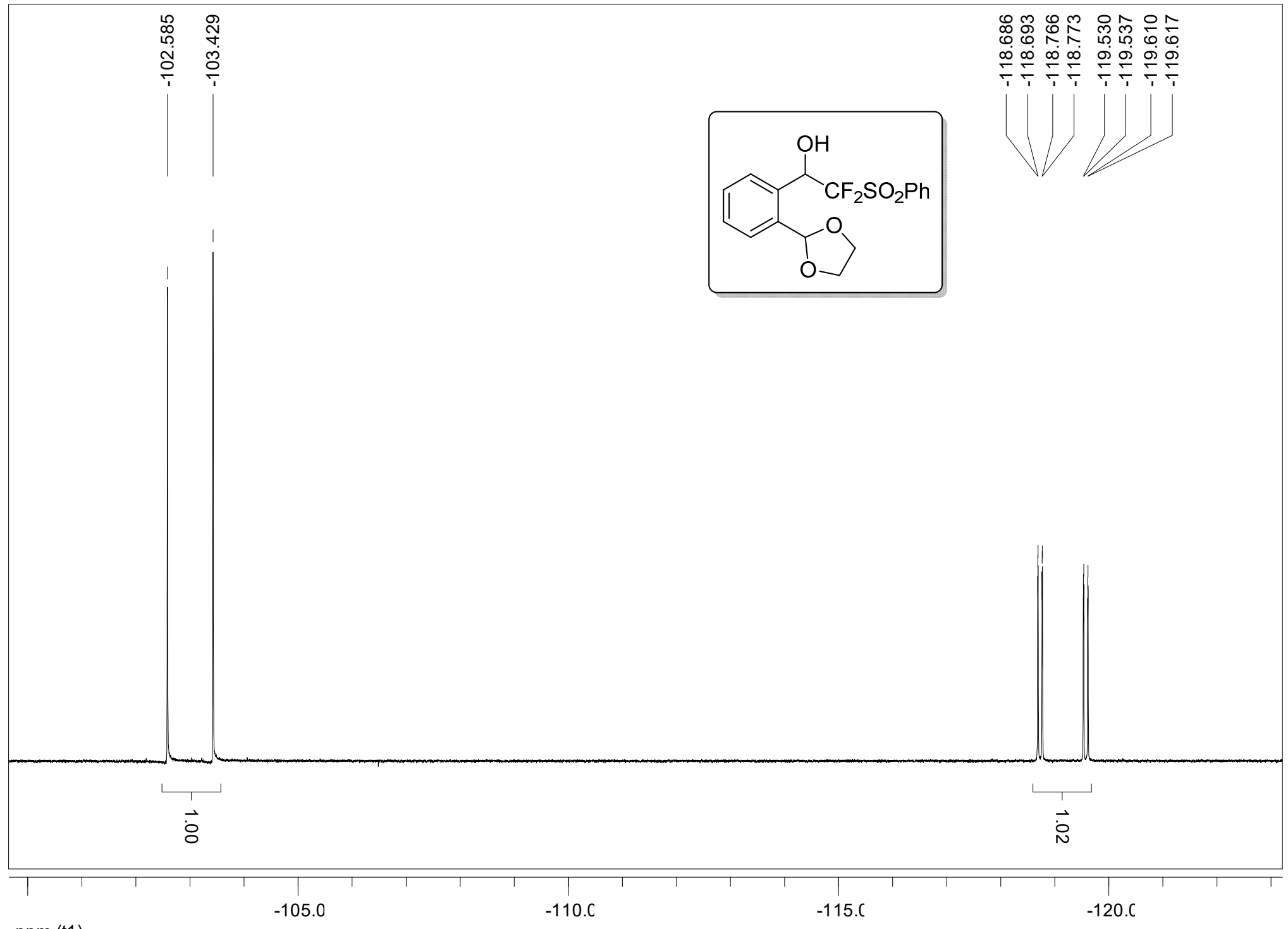

ppm (t1) 


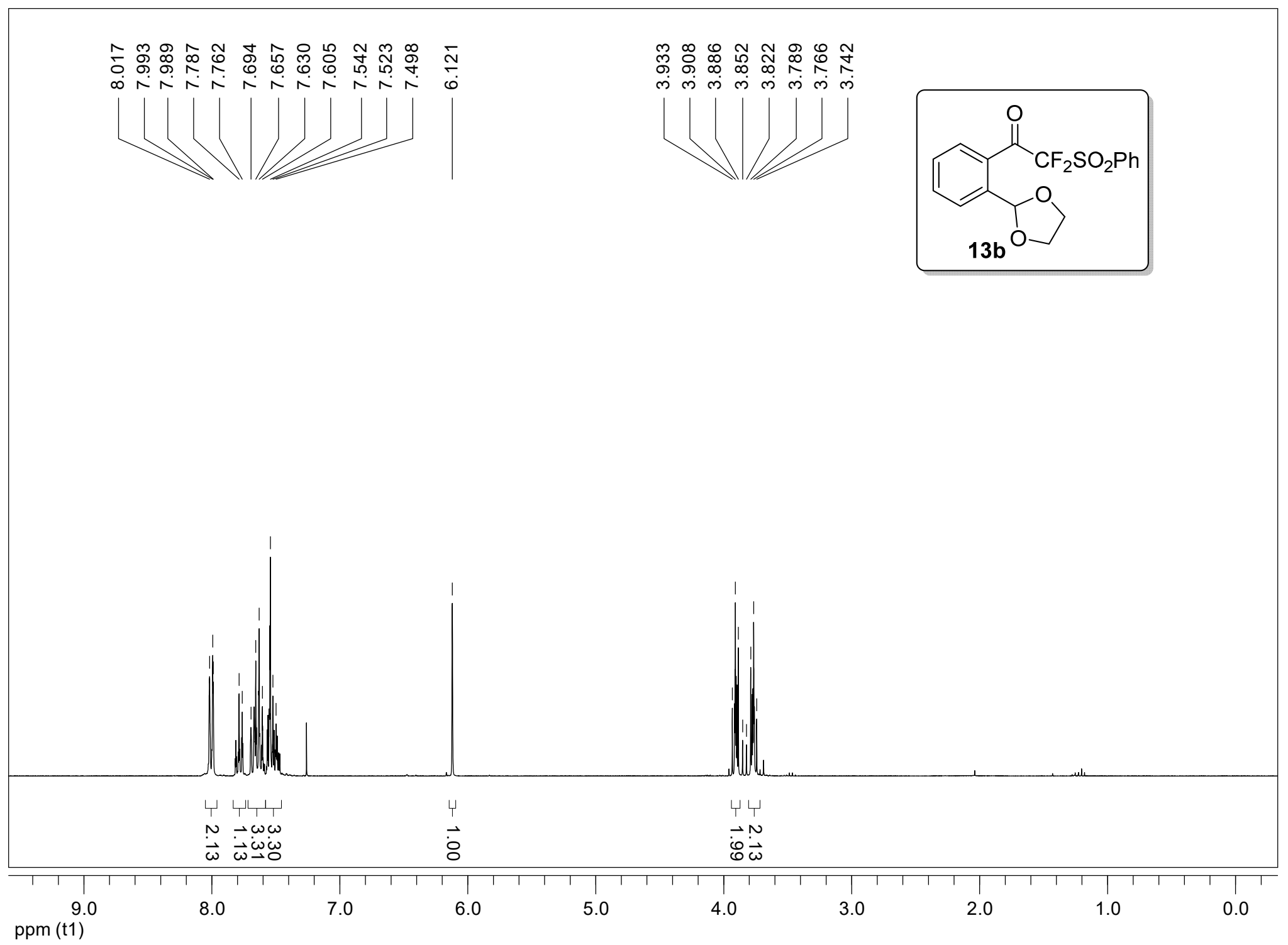




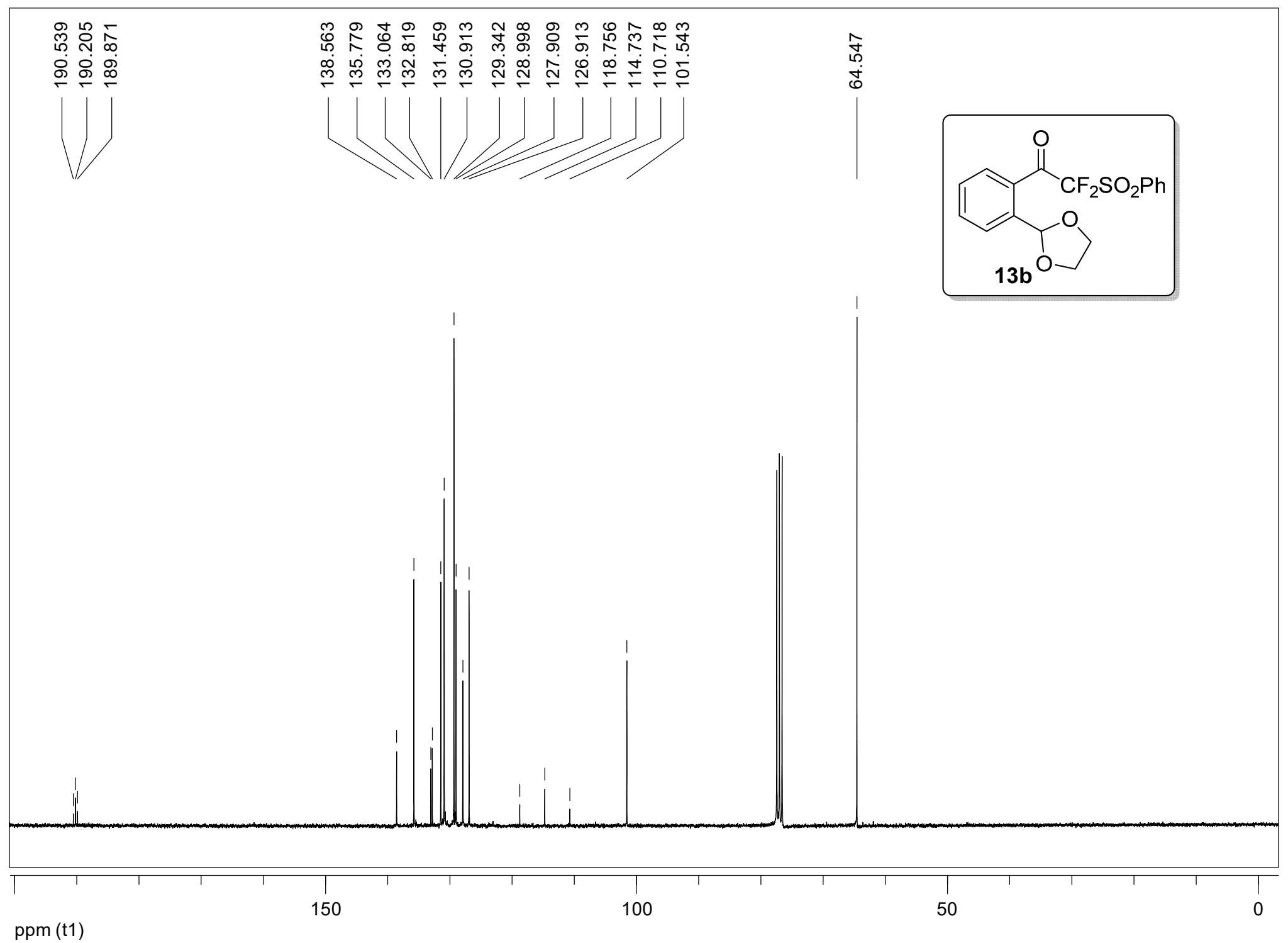




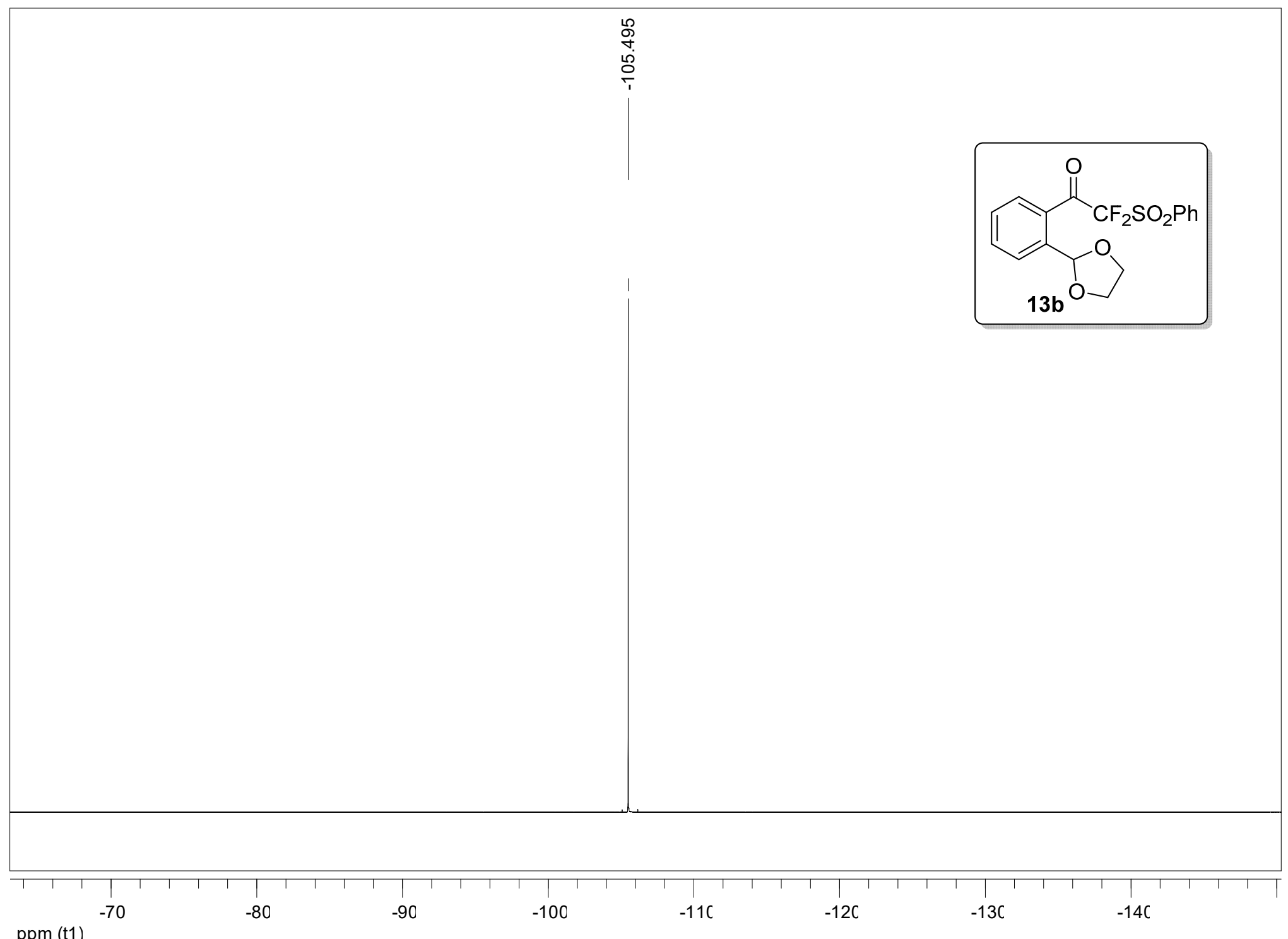




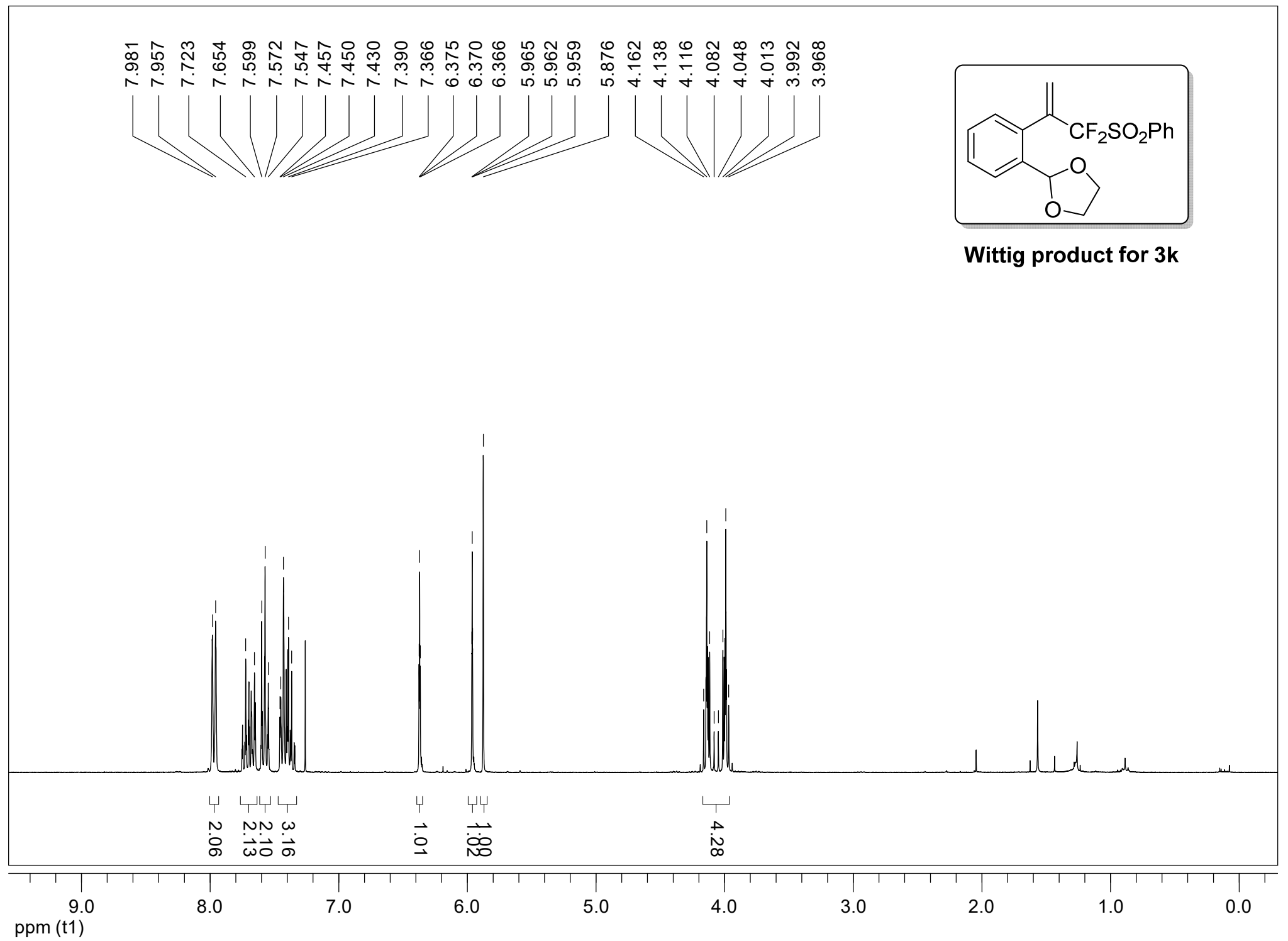




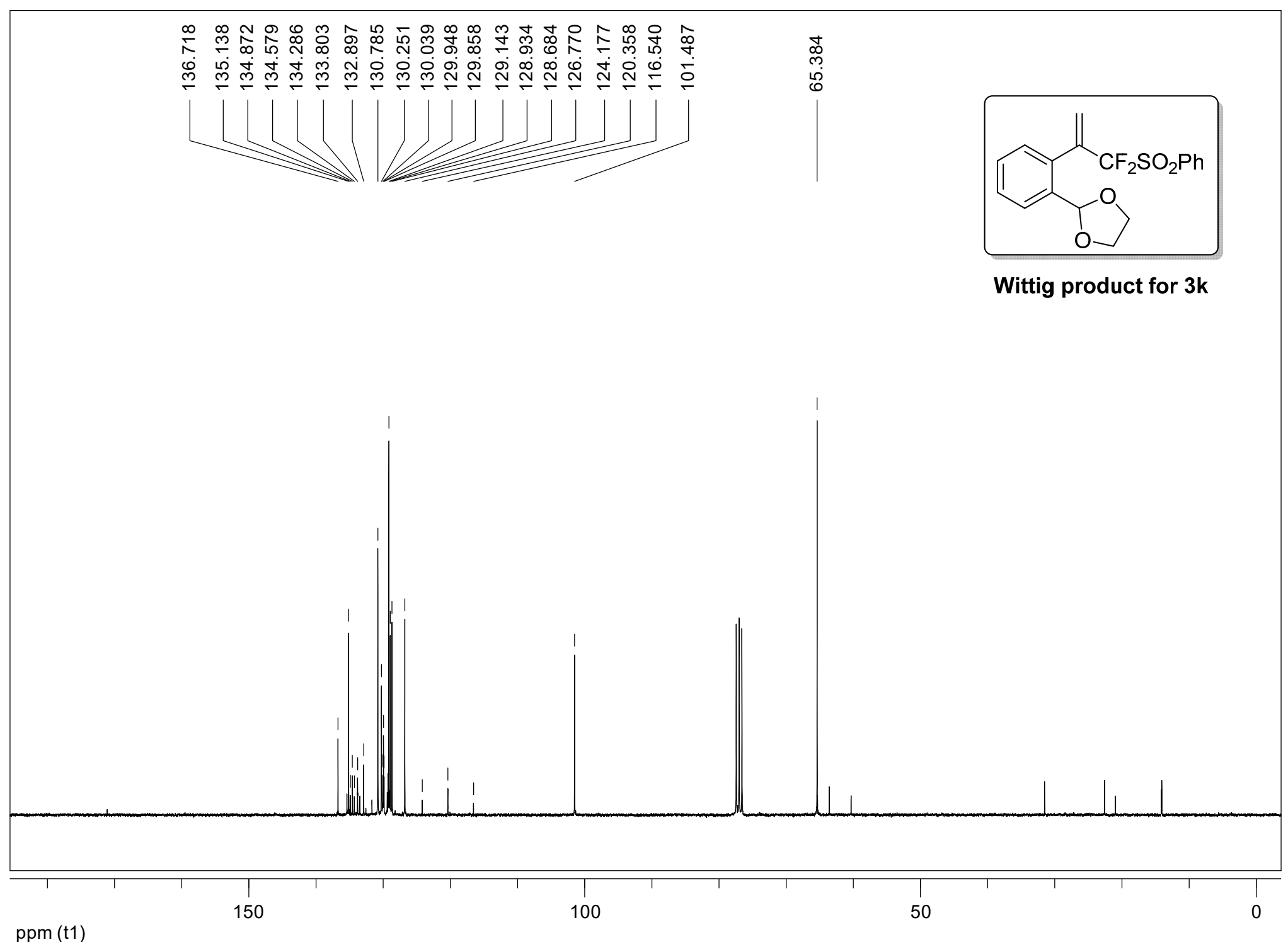




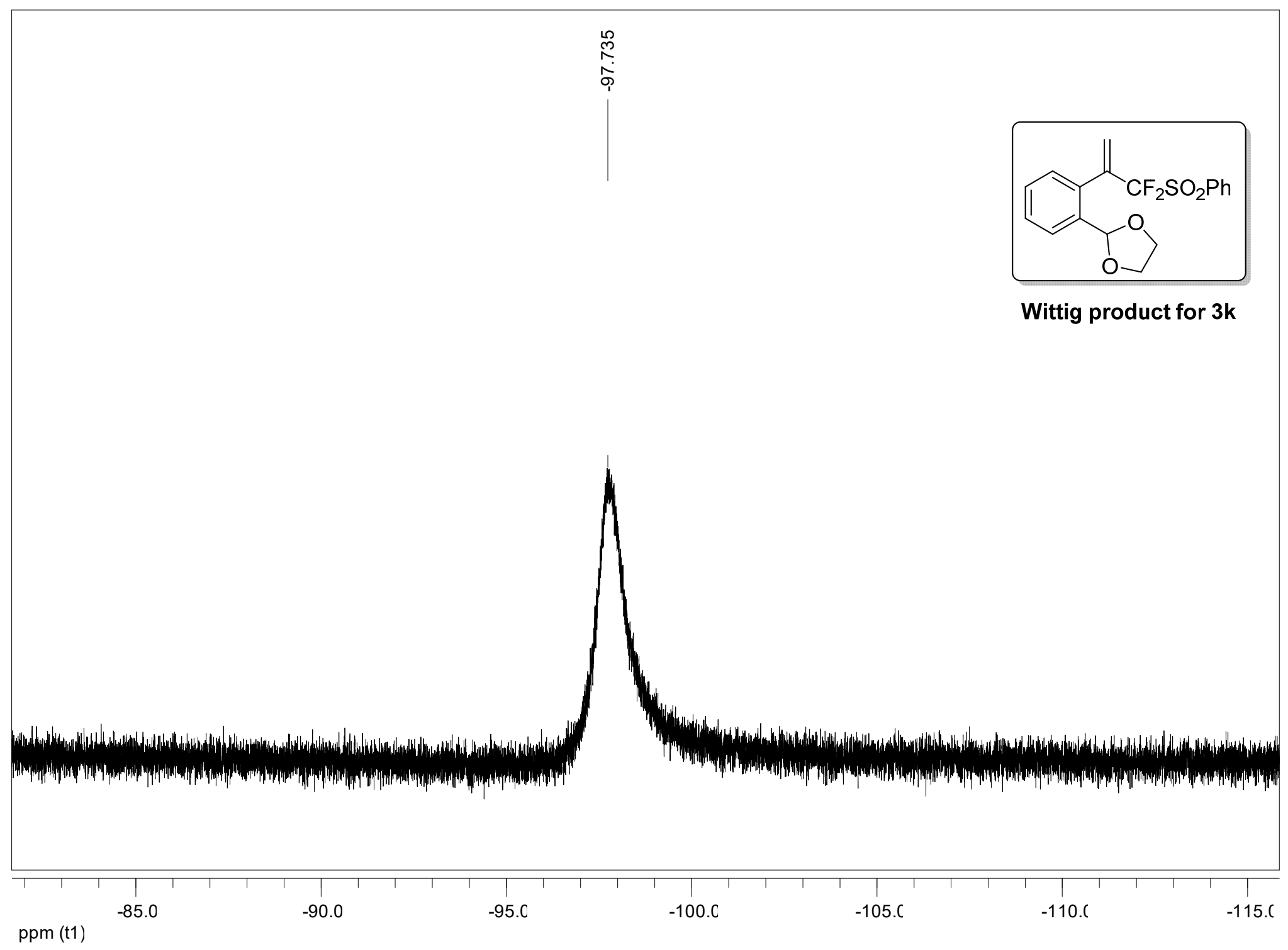




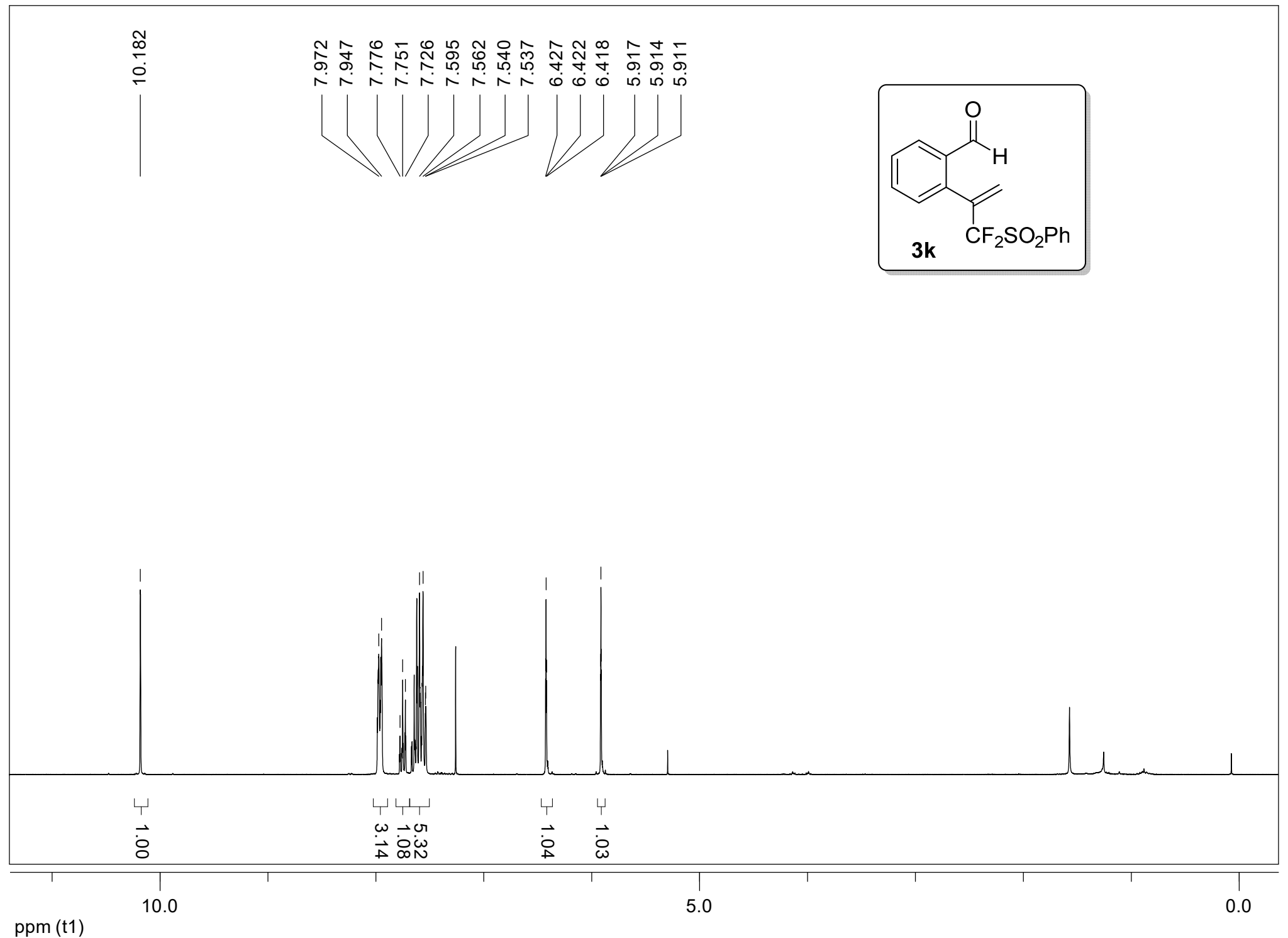




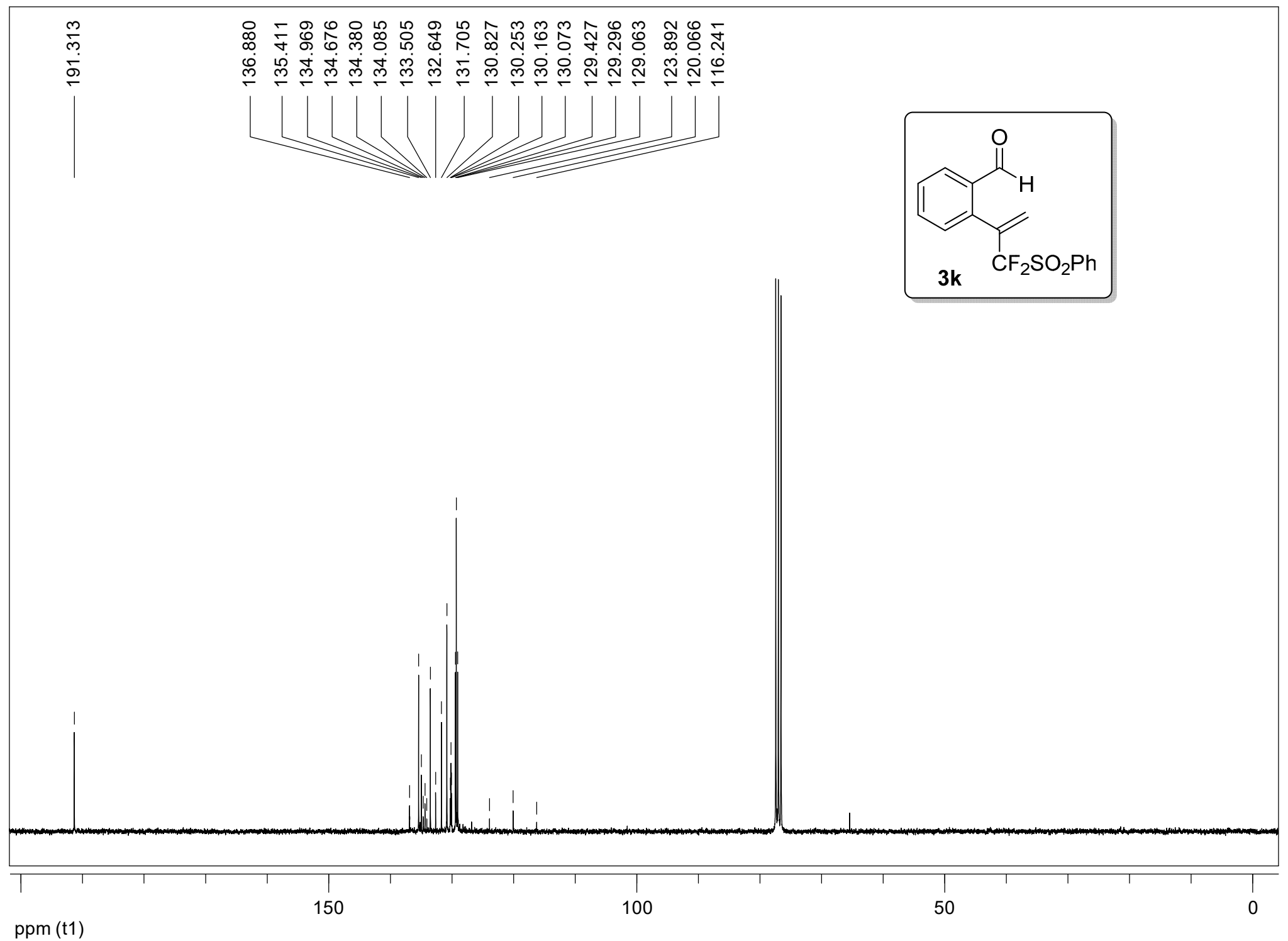




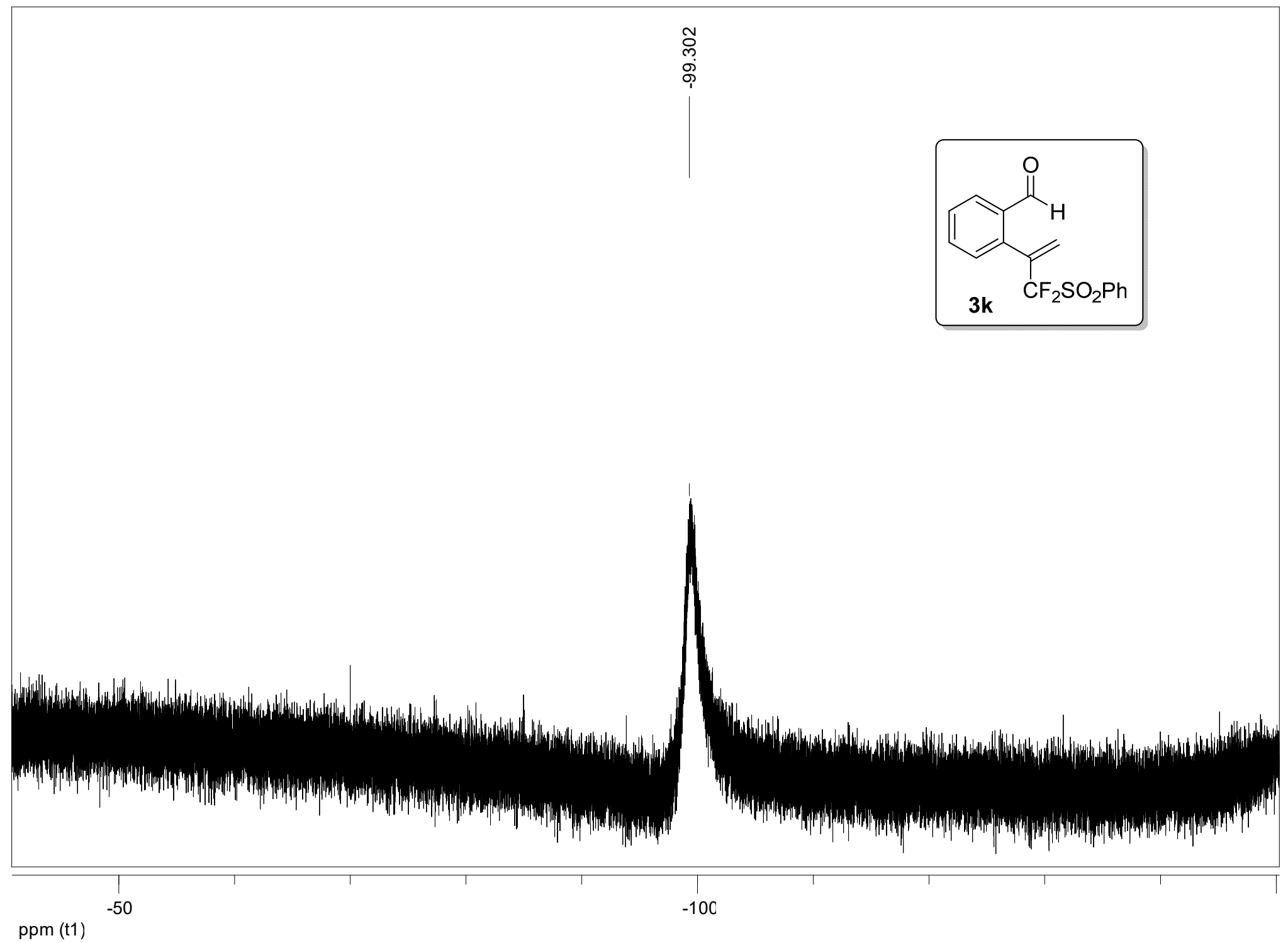




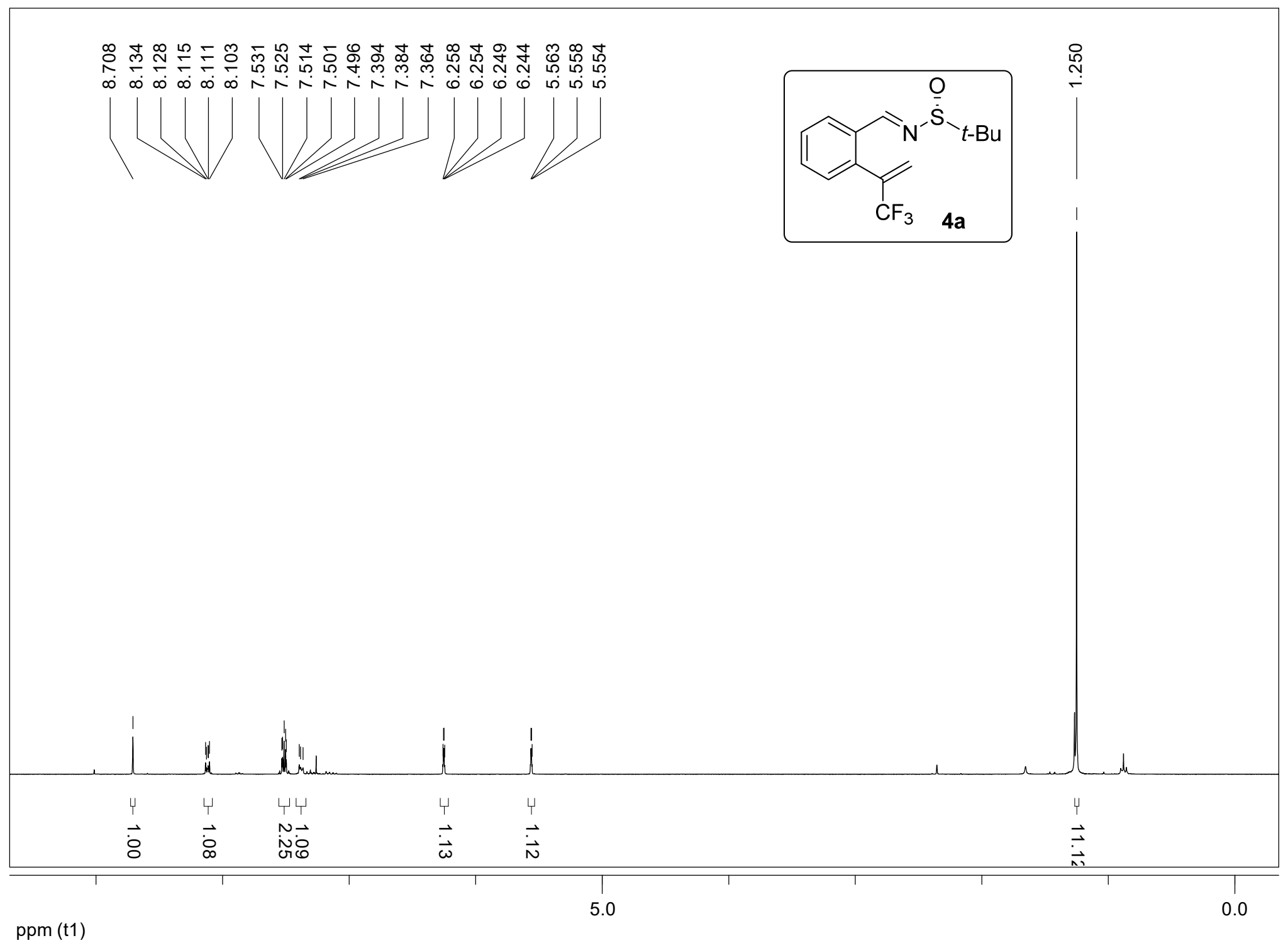




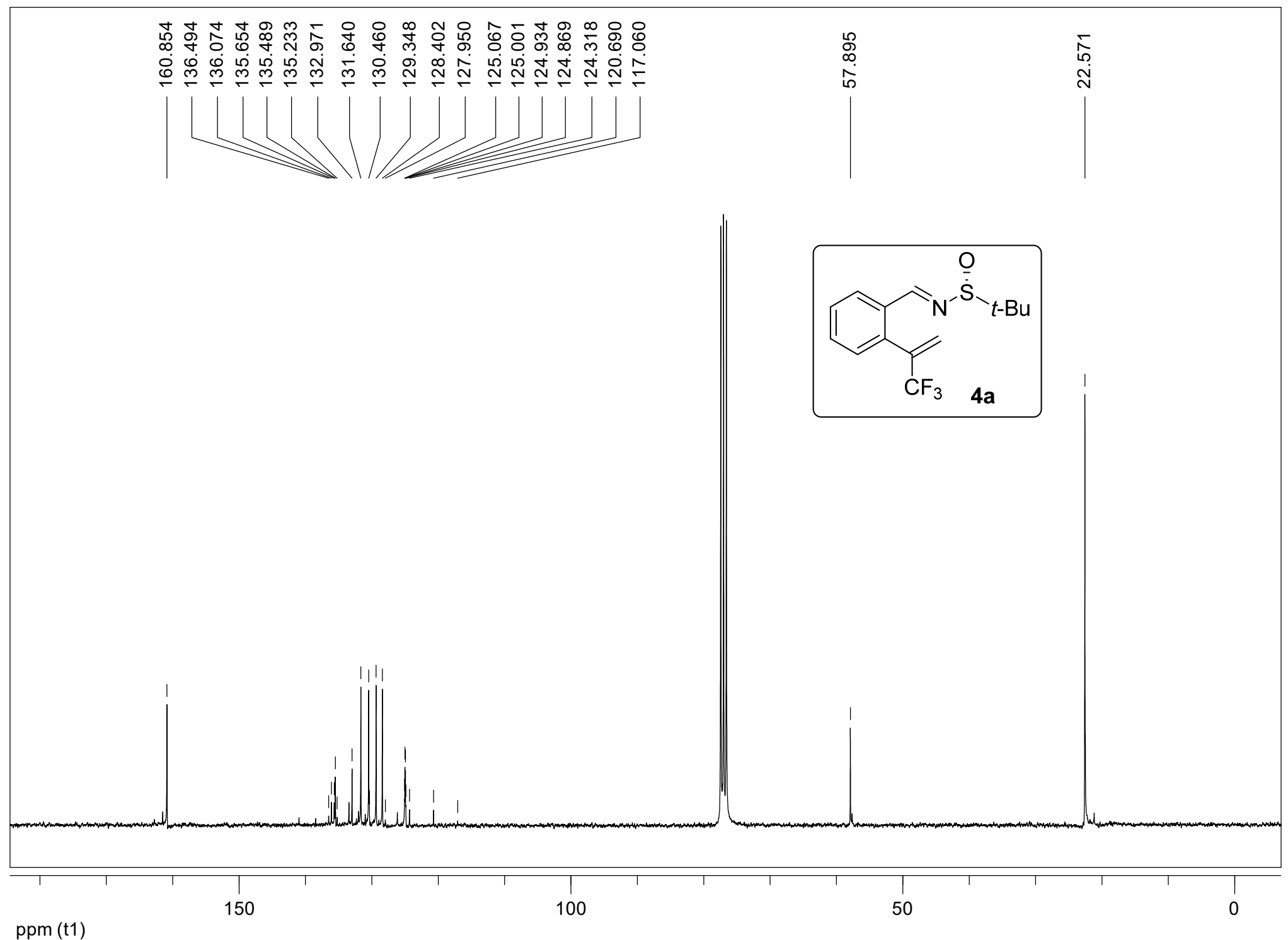




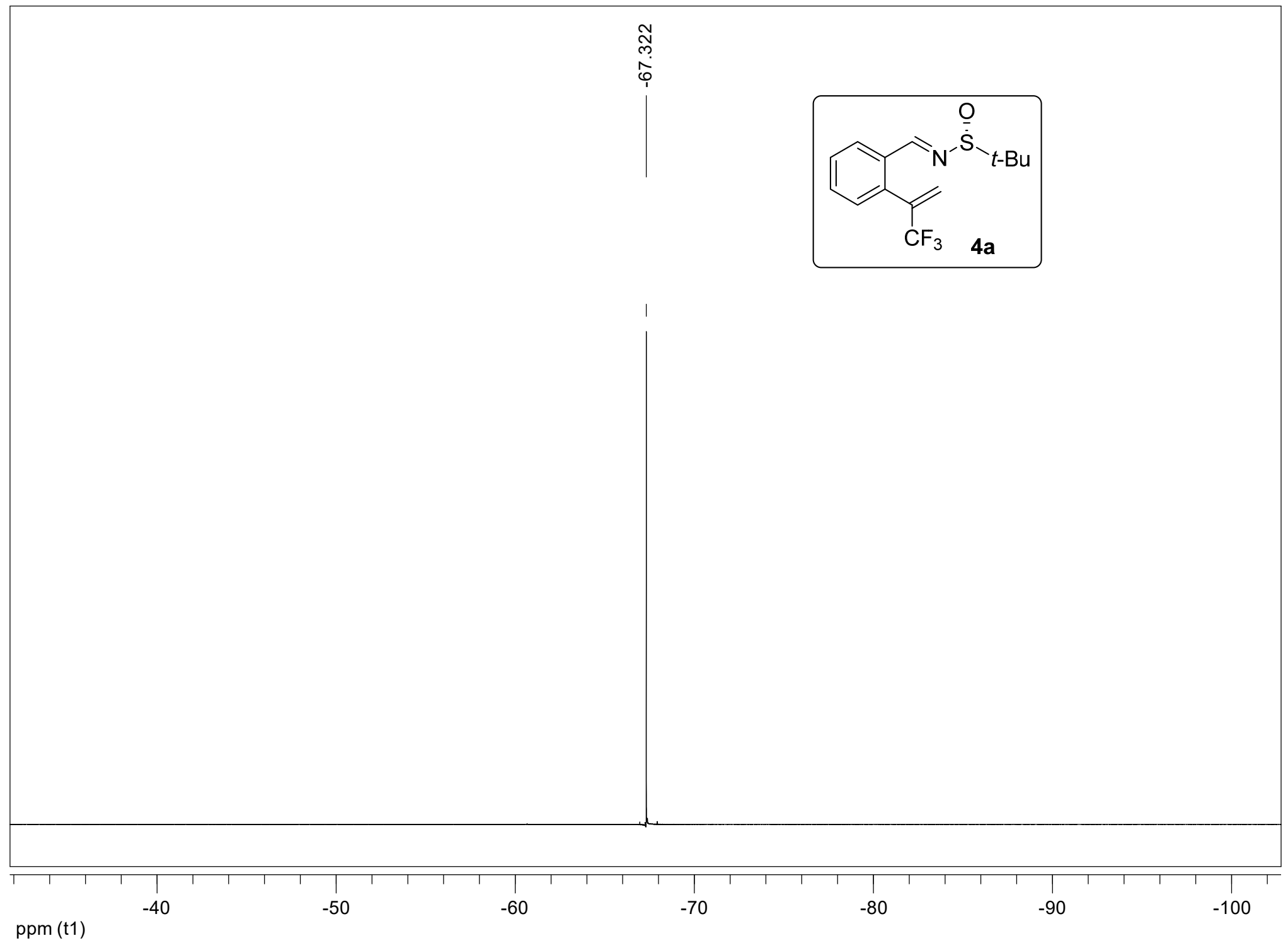




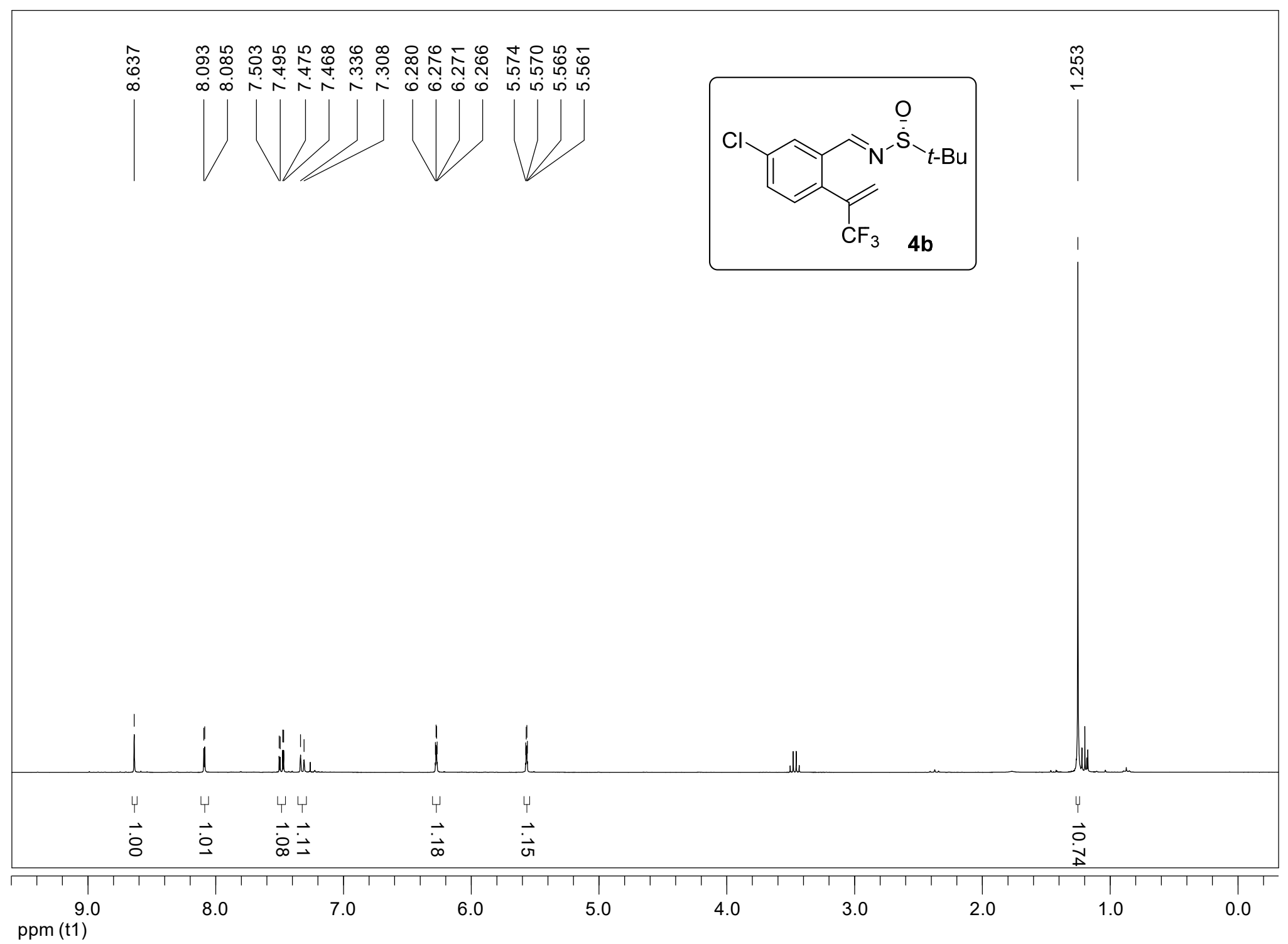




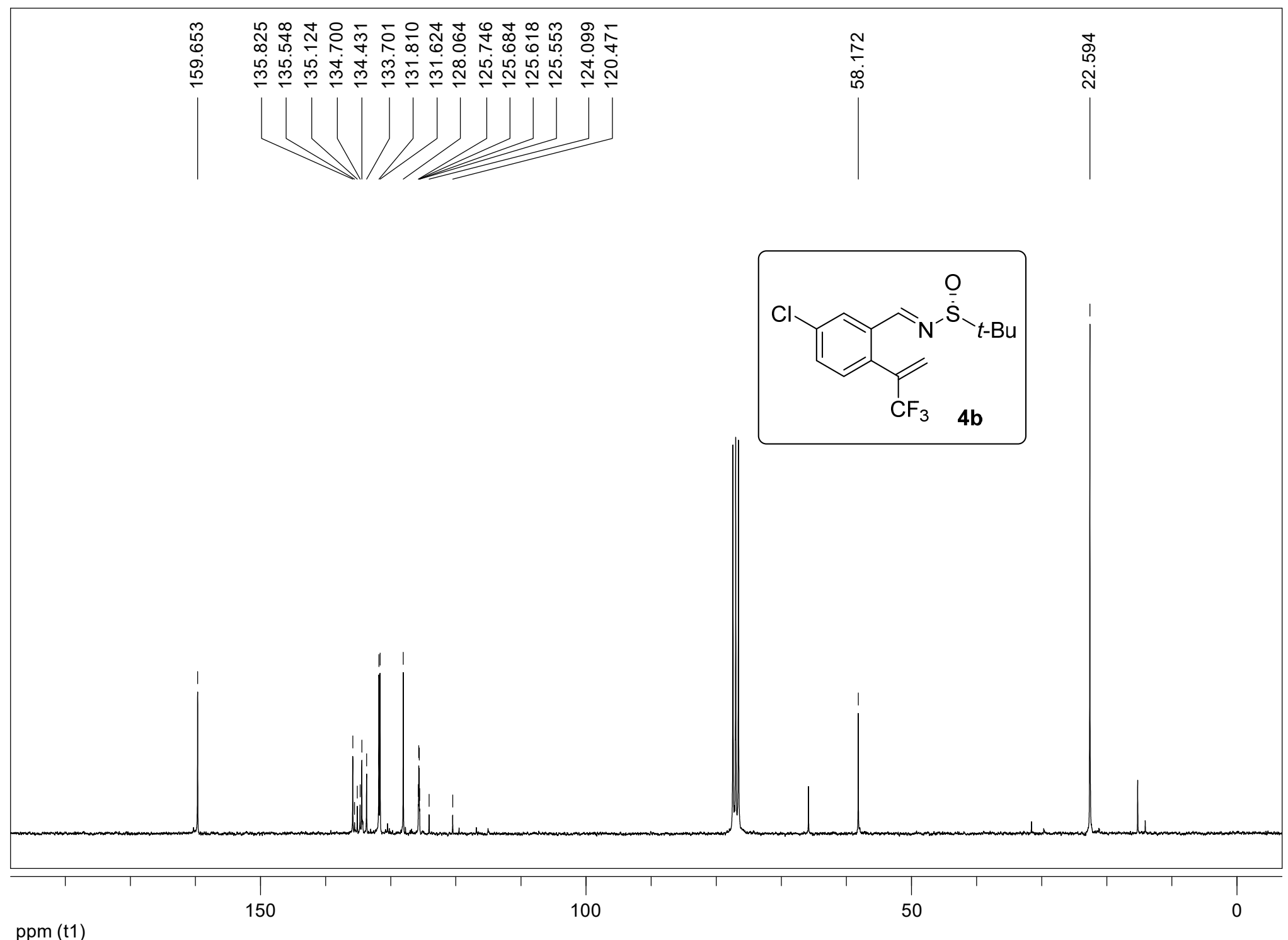




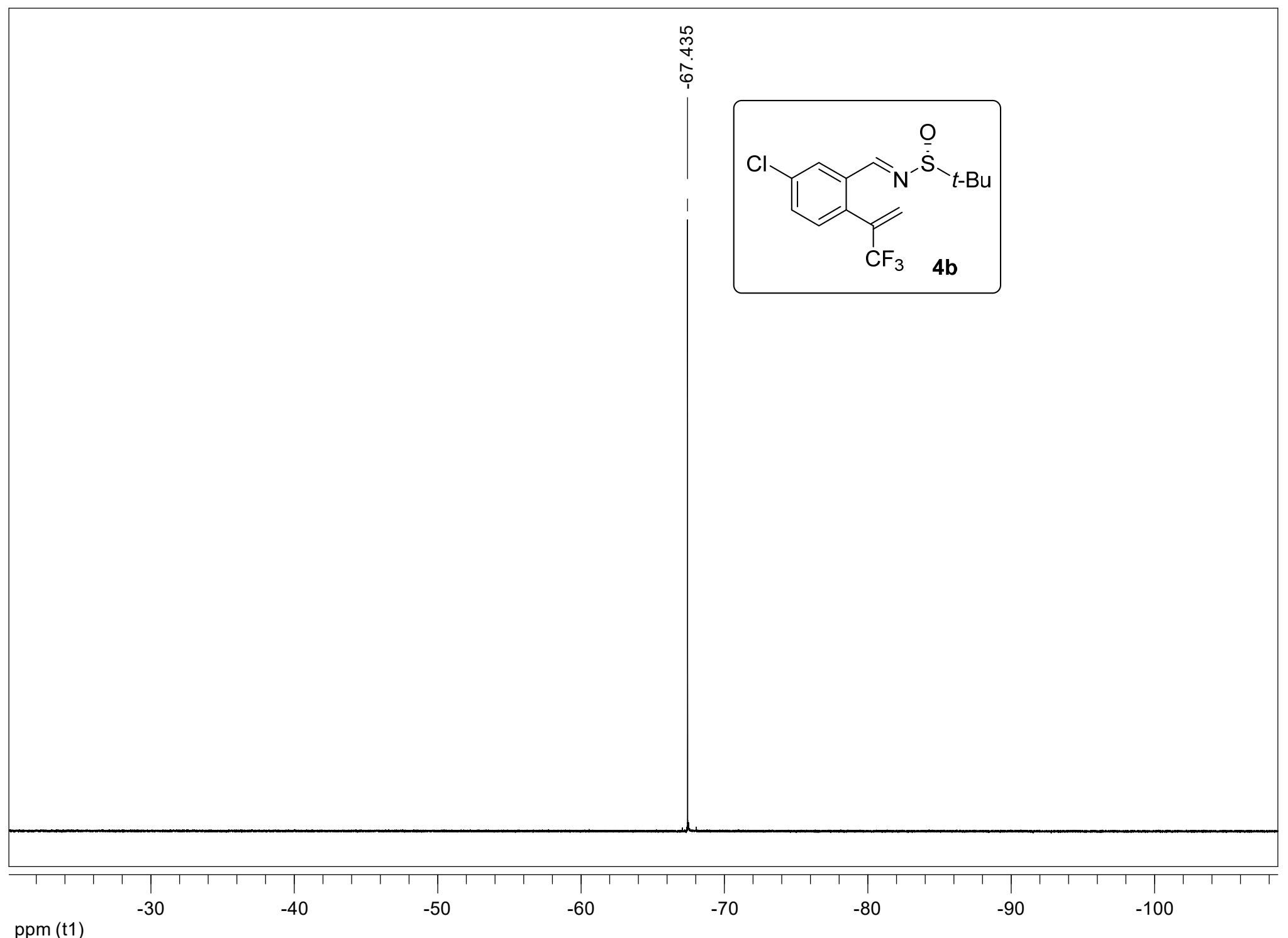




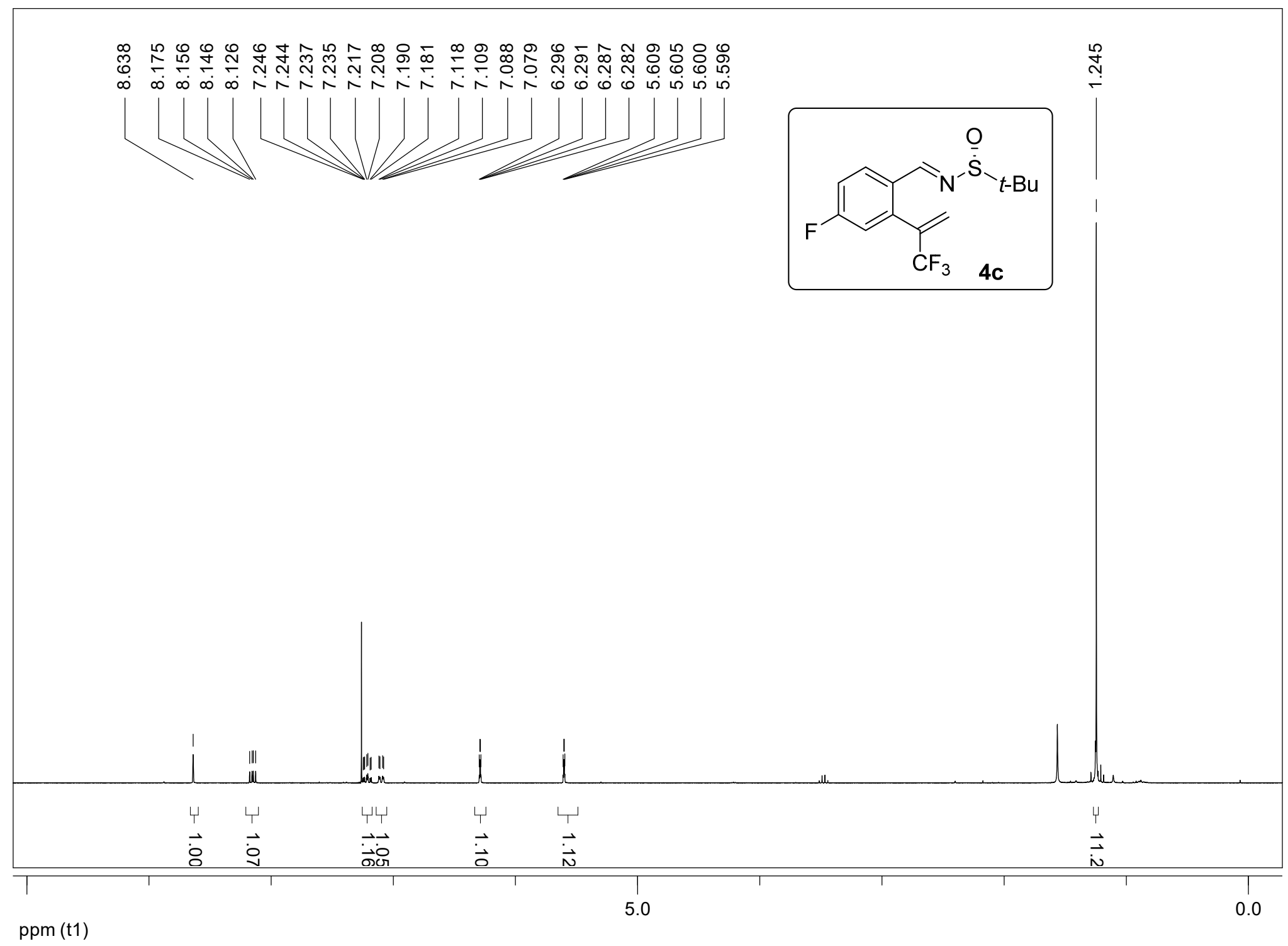




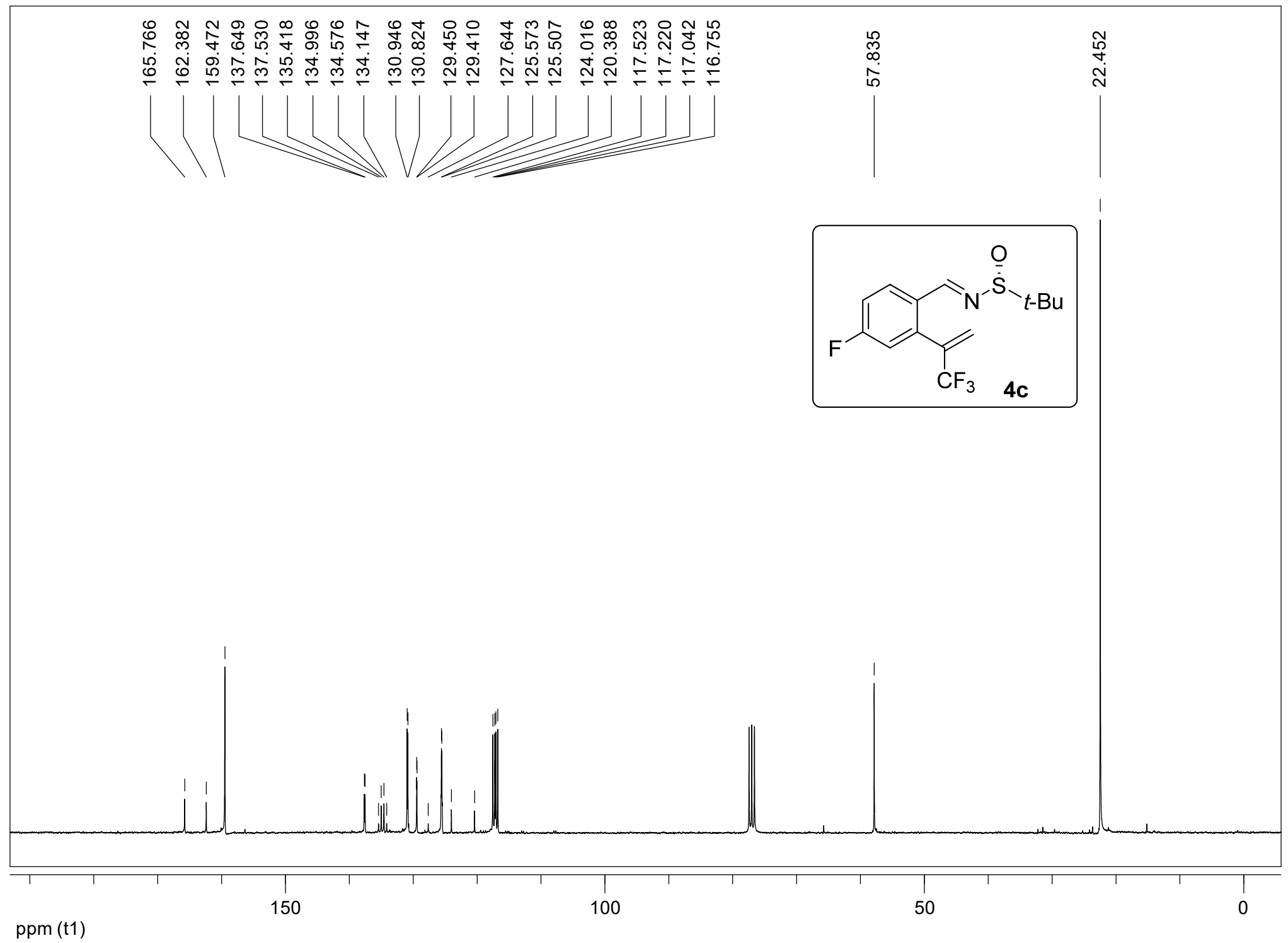




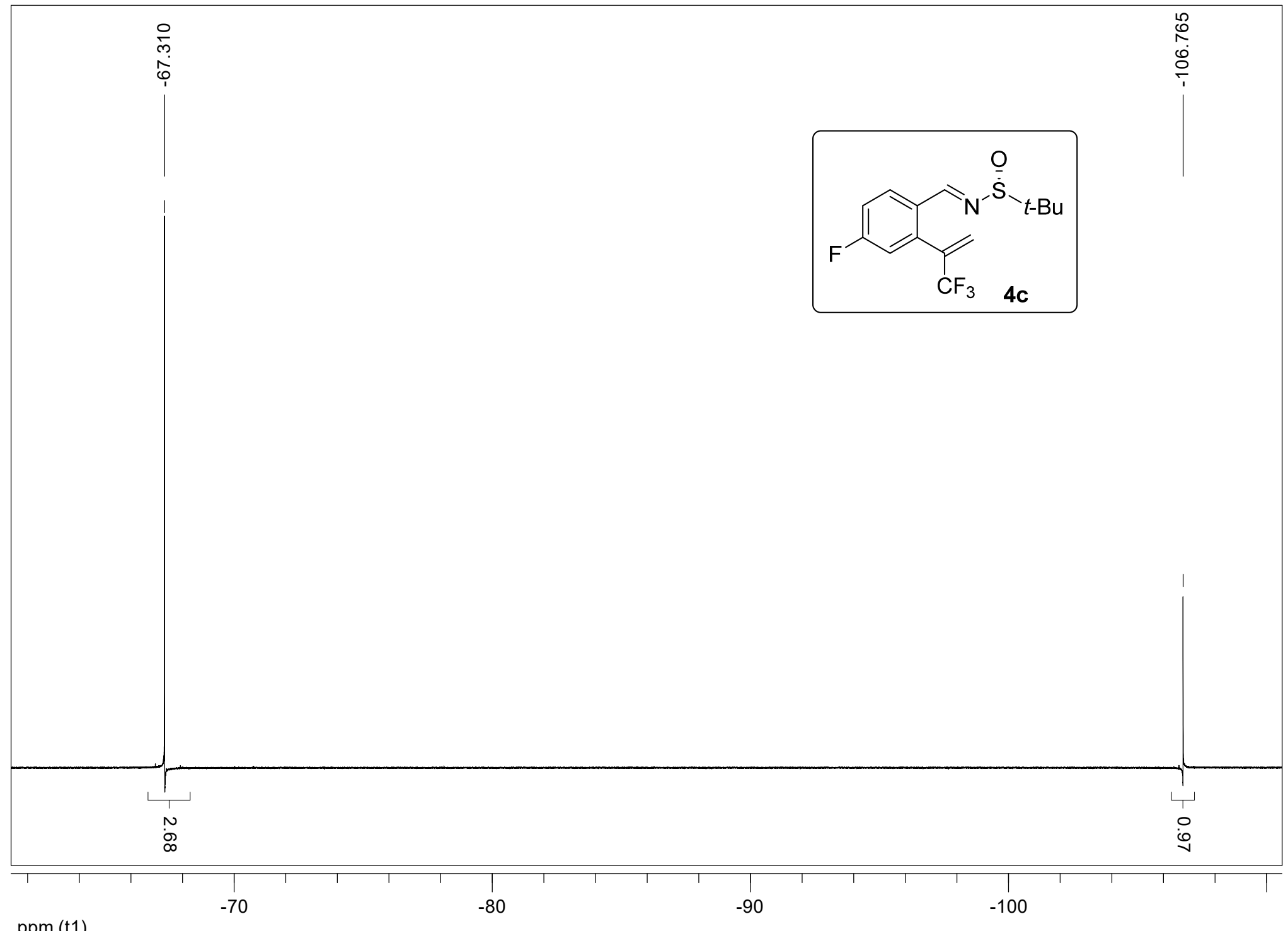

ppm (t1) 


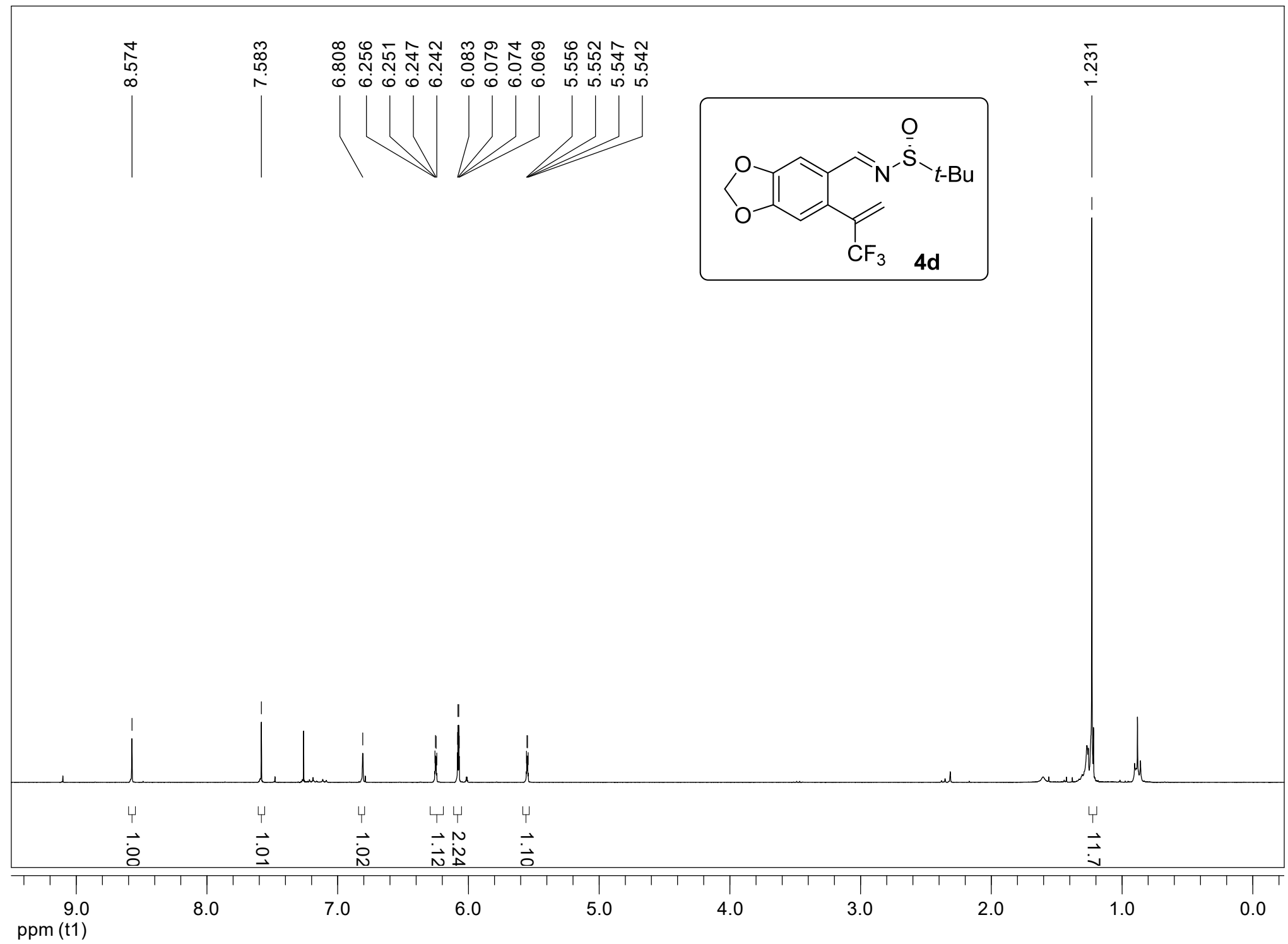




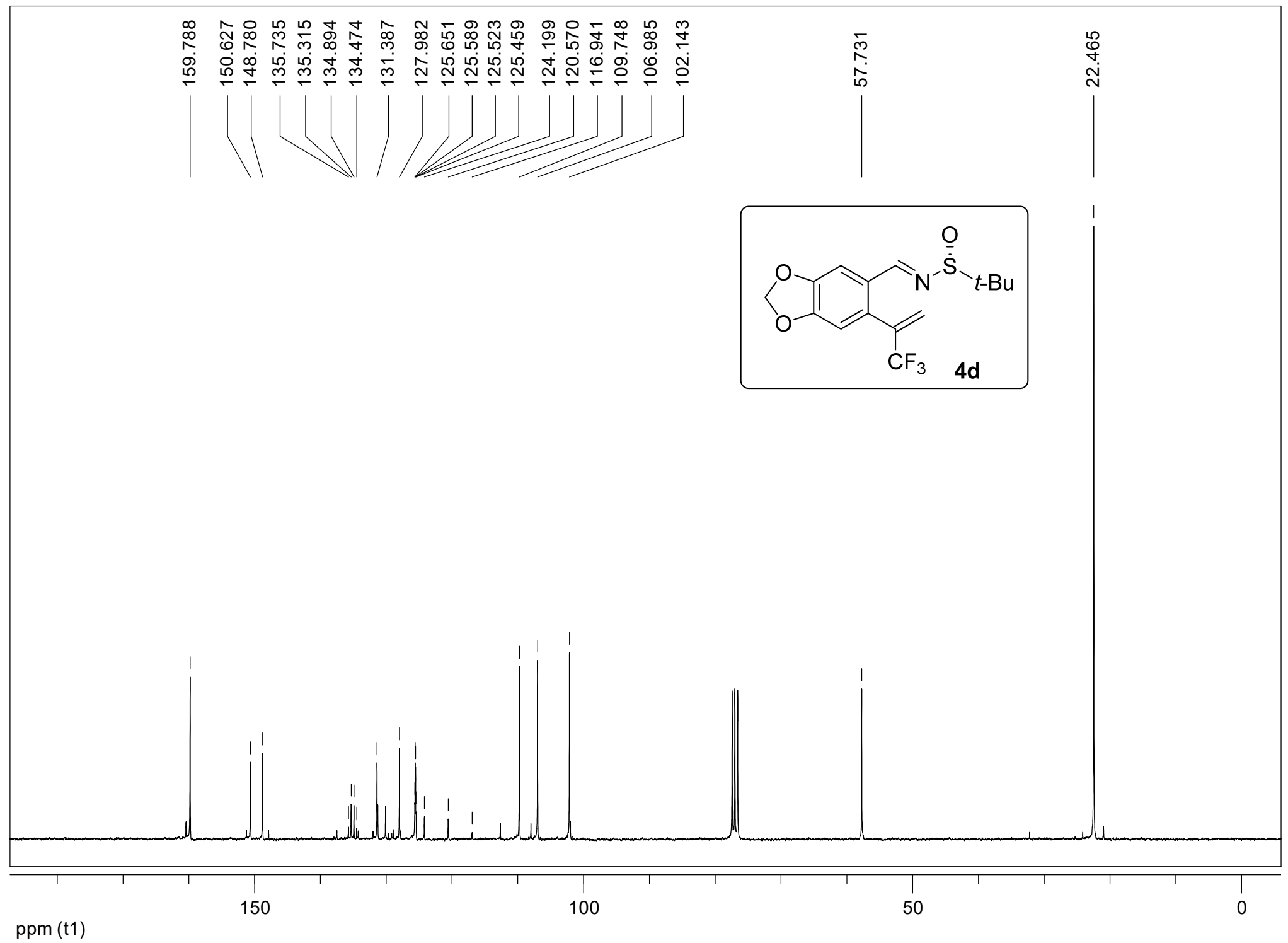




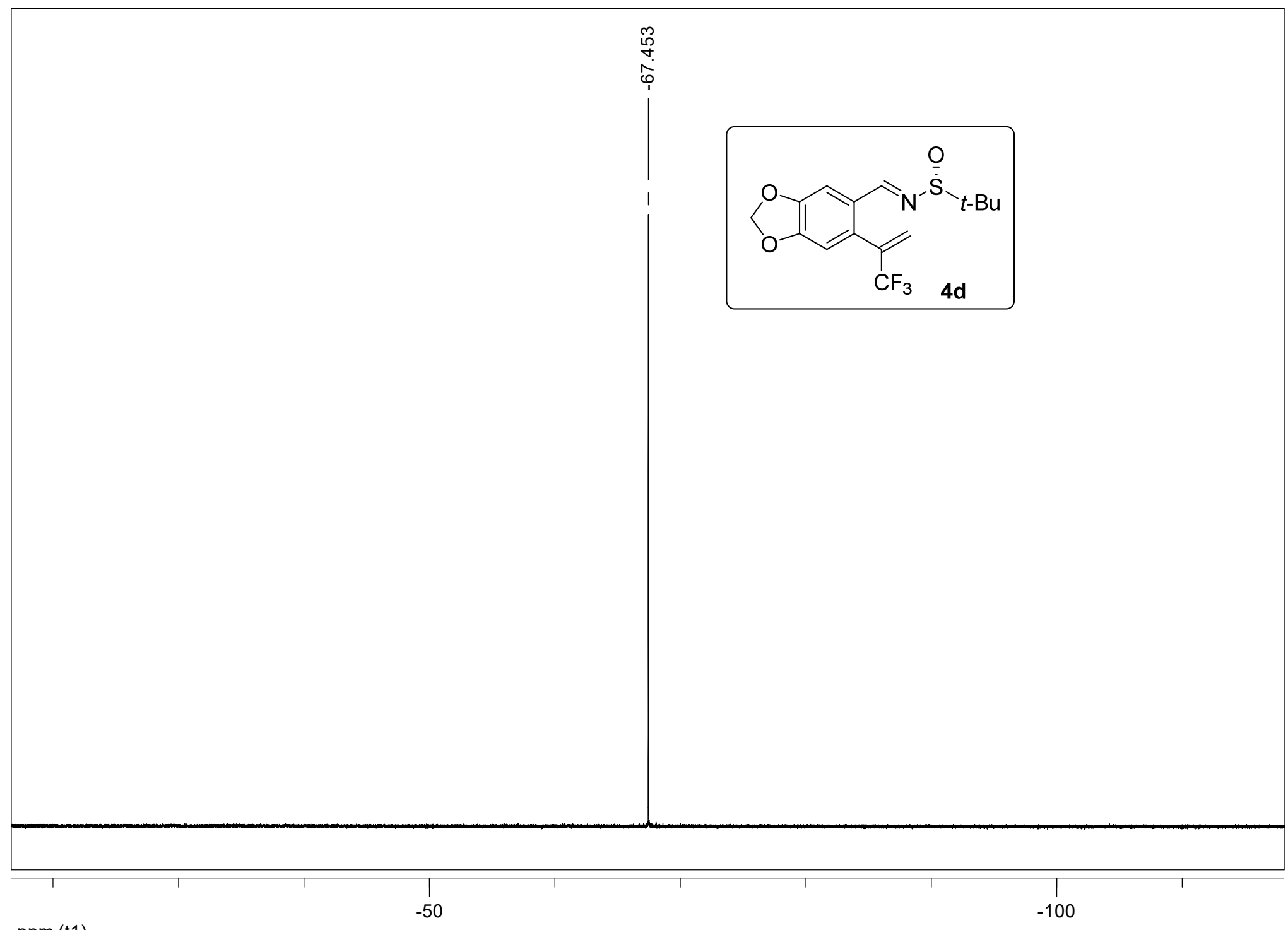

ppm (t1) 


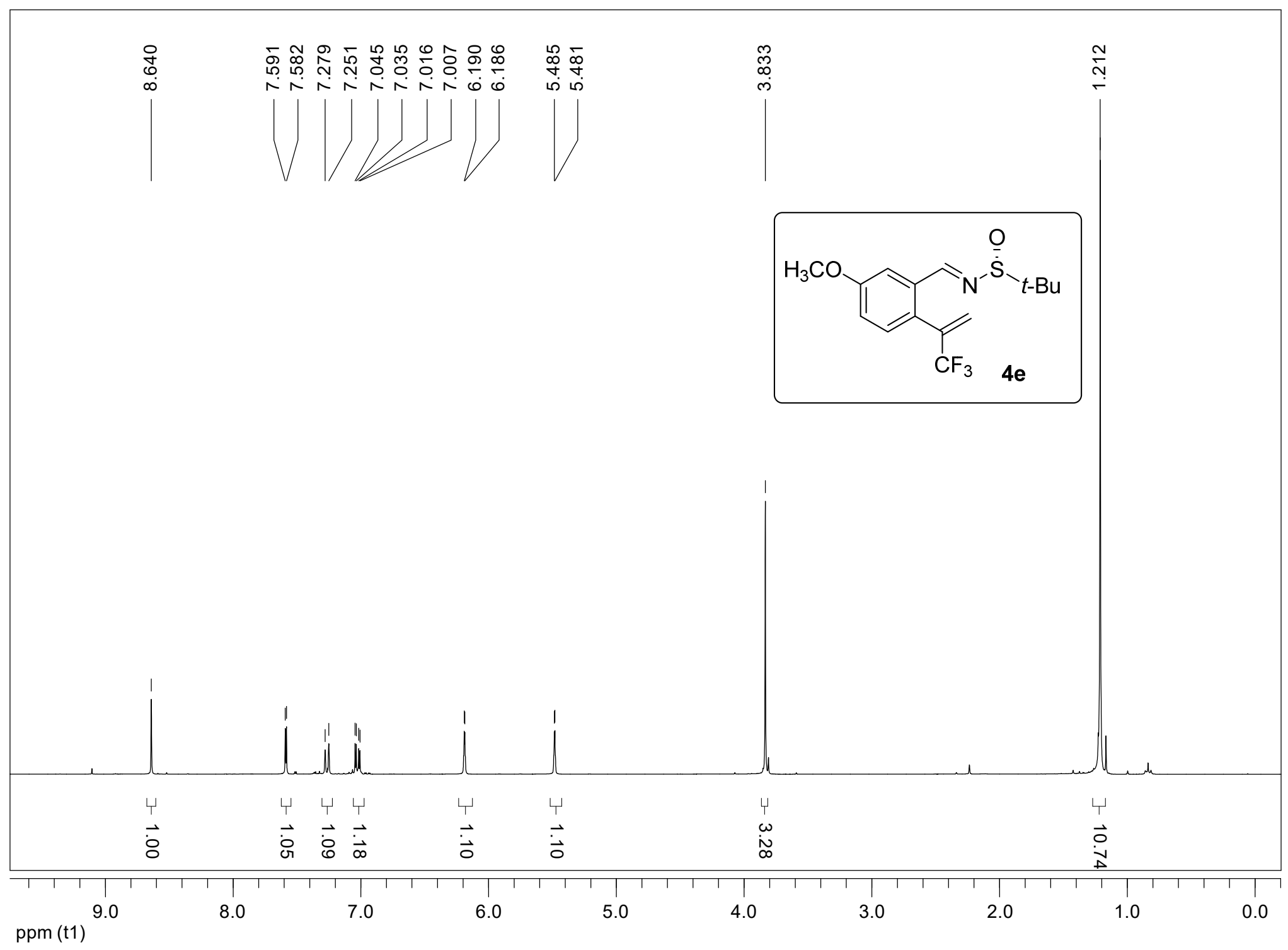




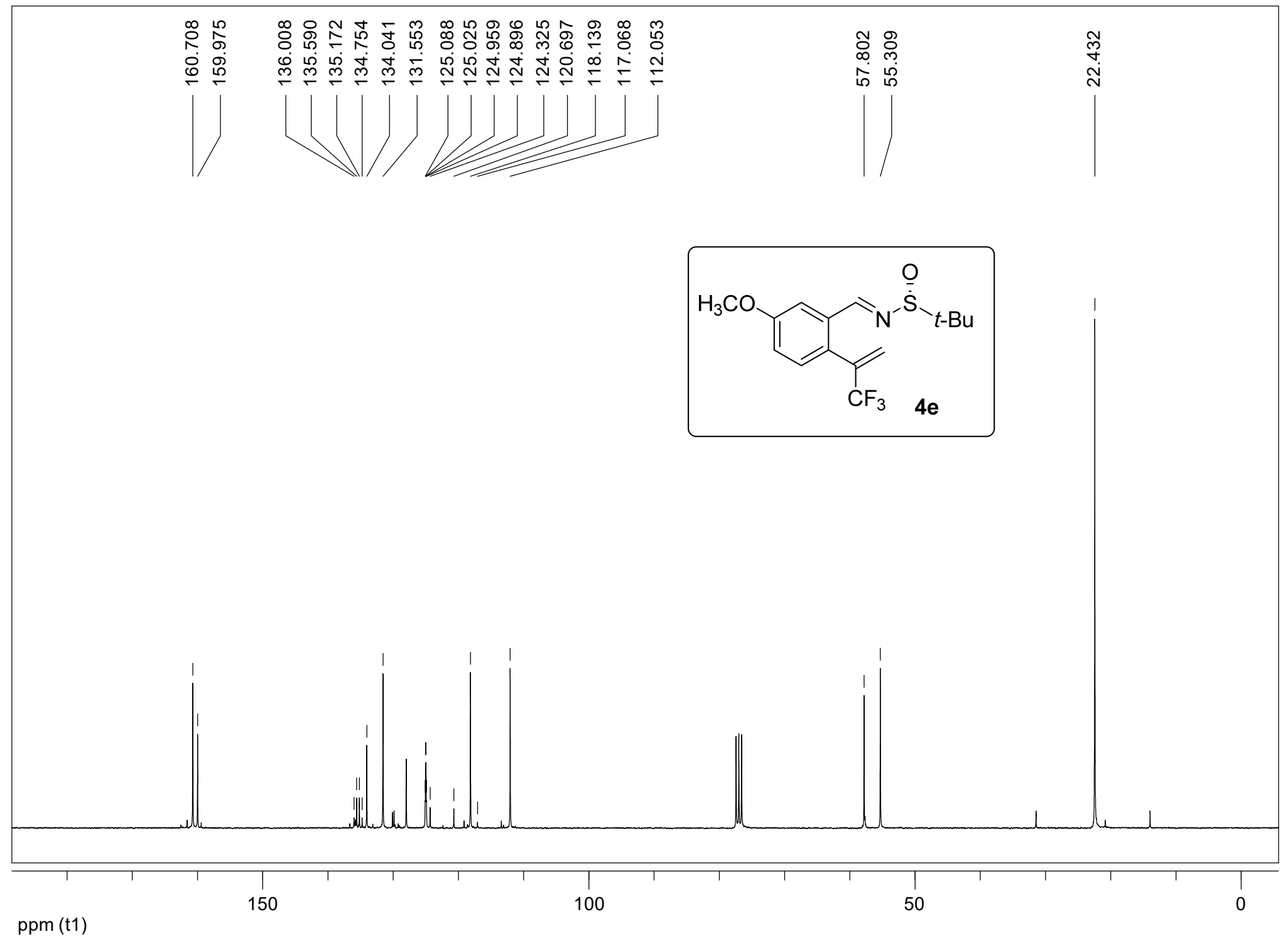




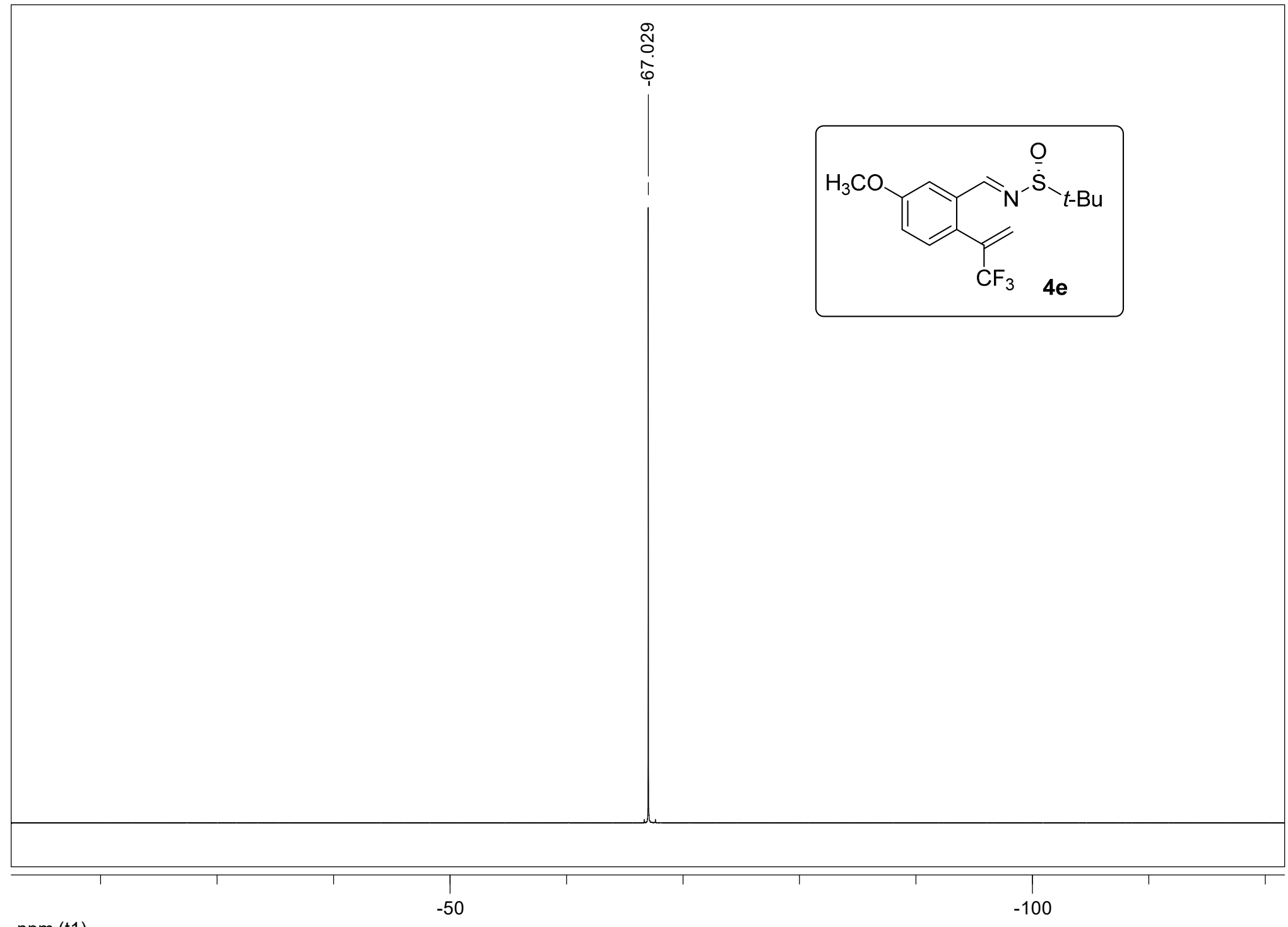

ppm (t1) 


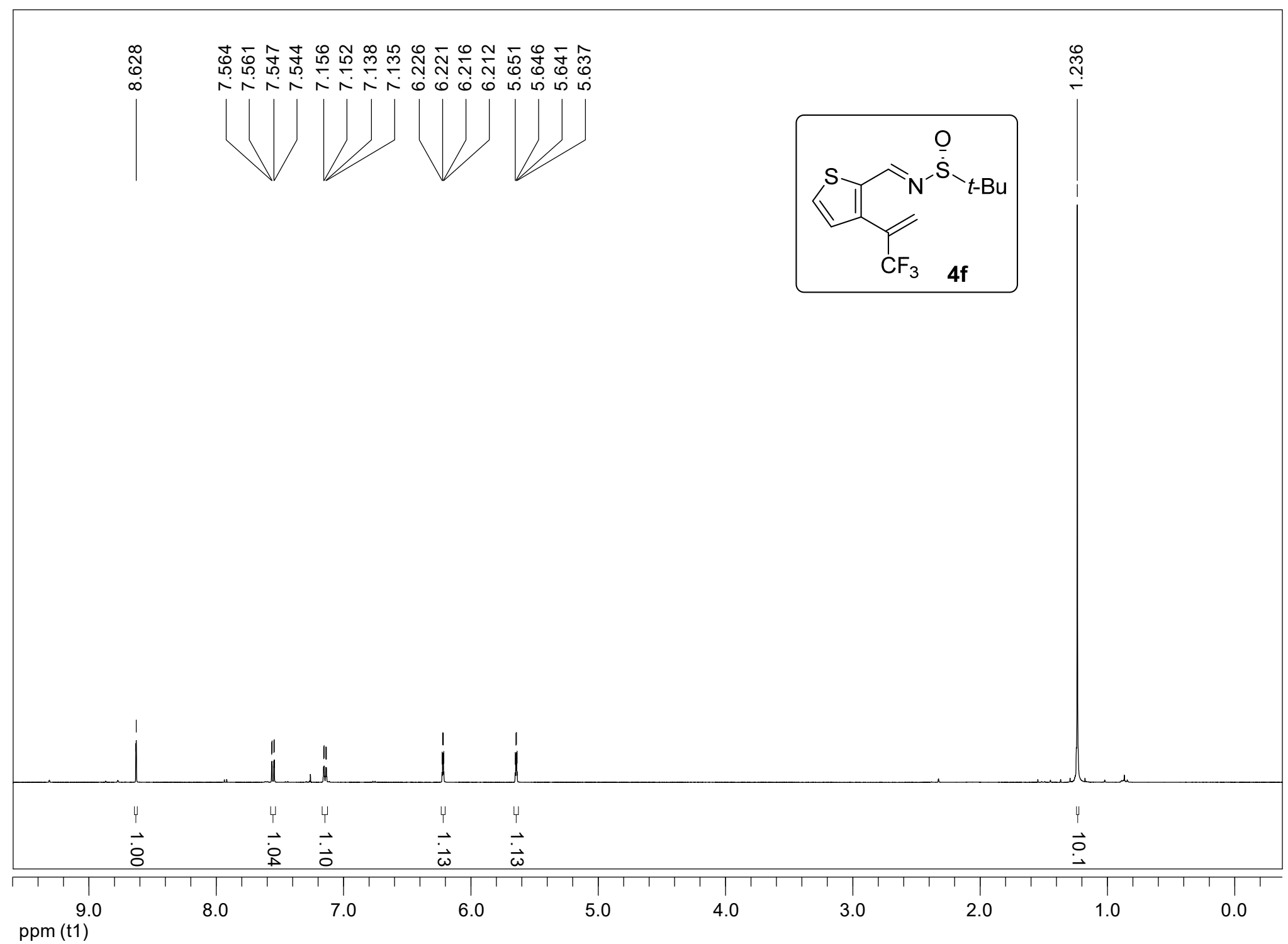




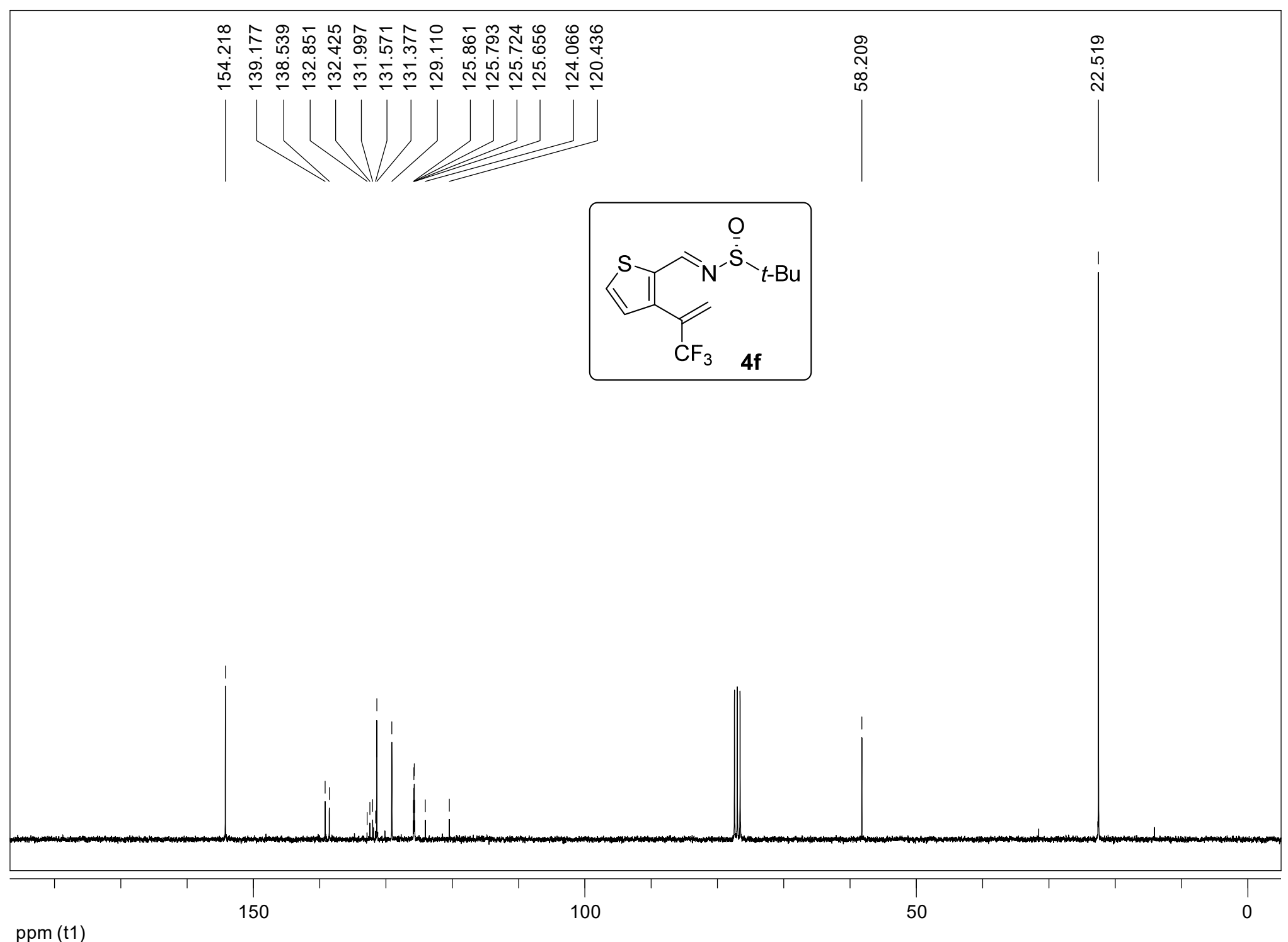




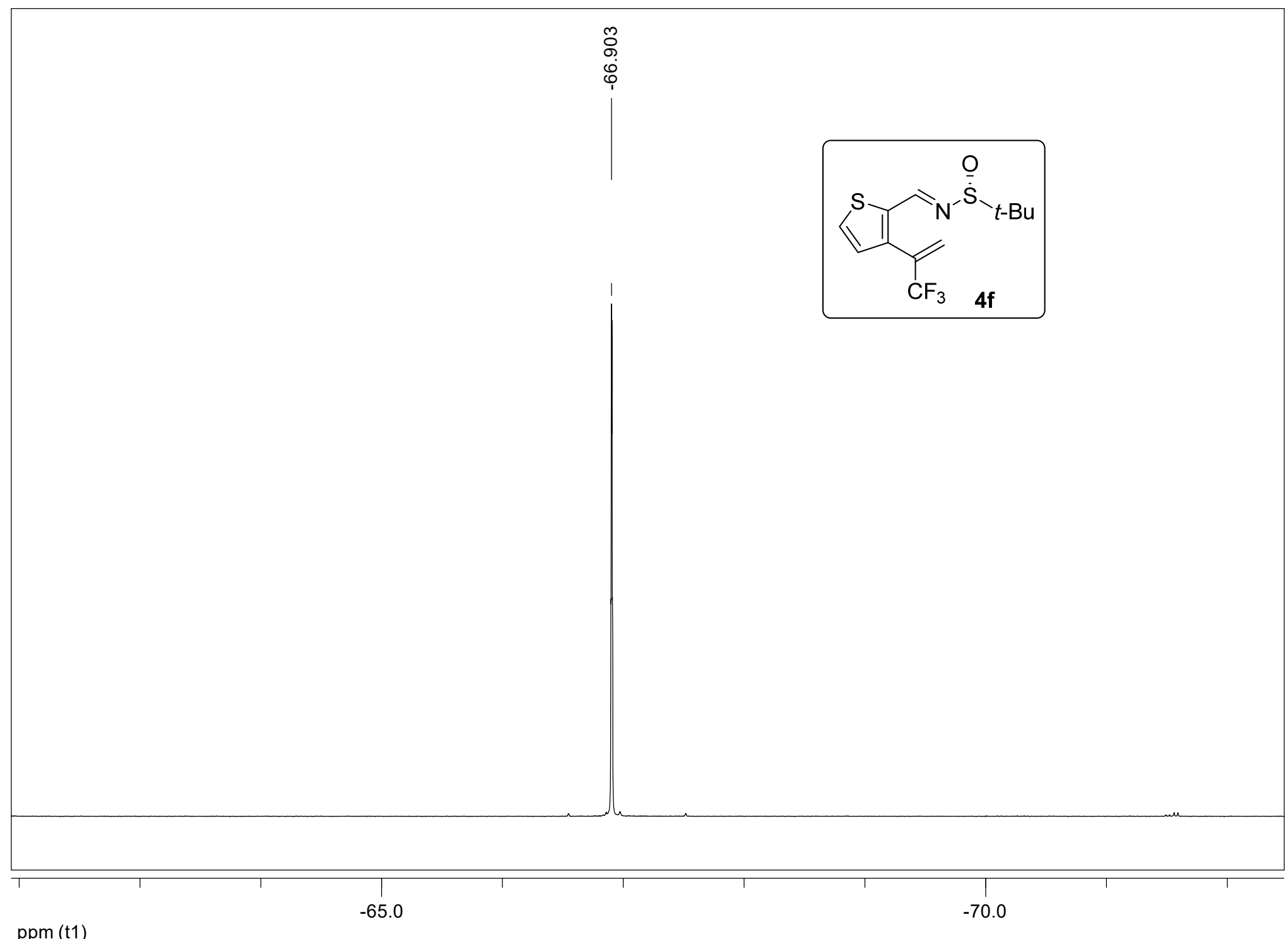




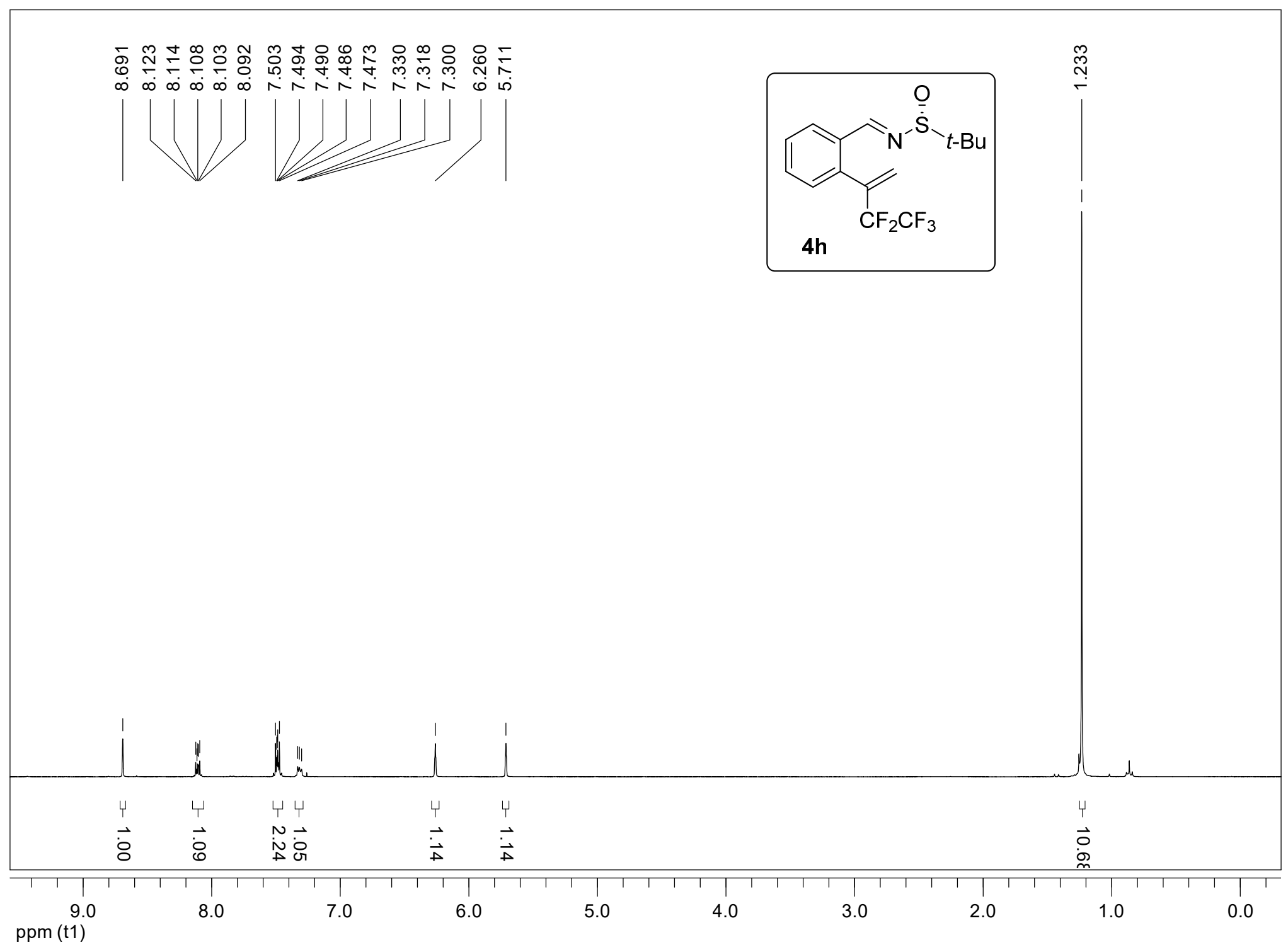




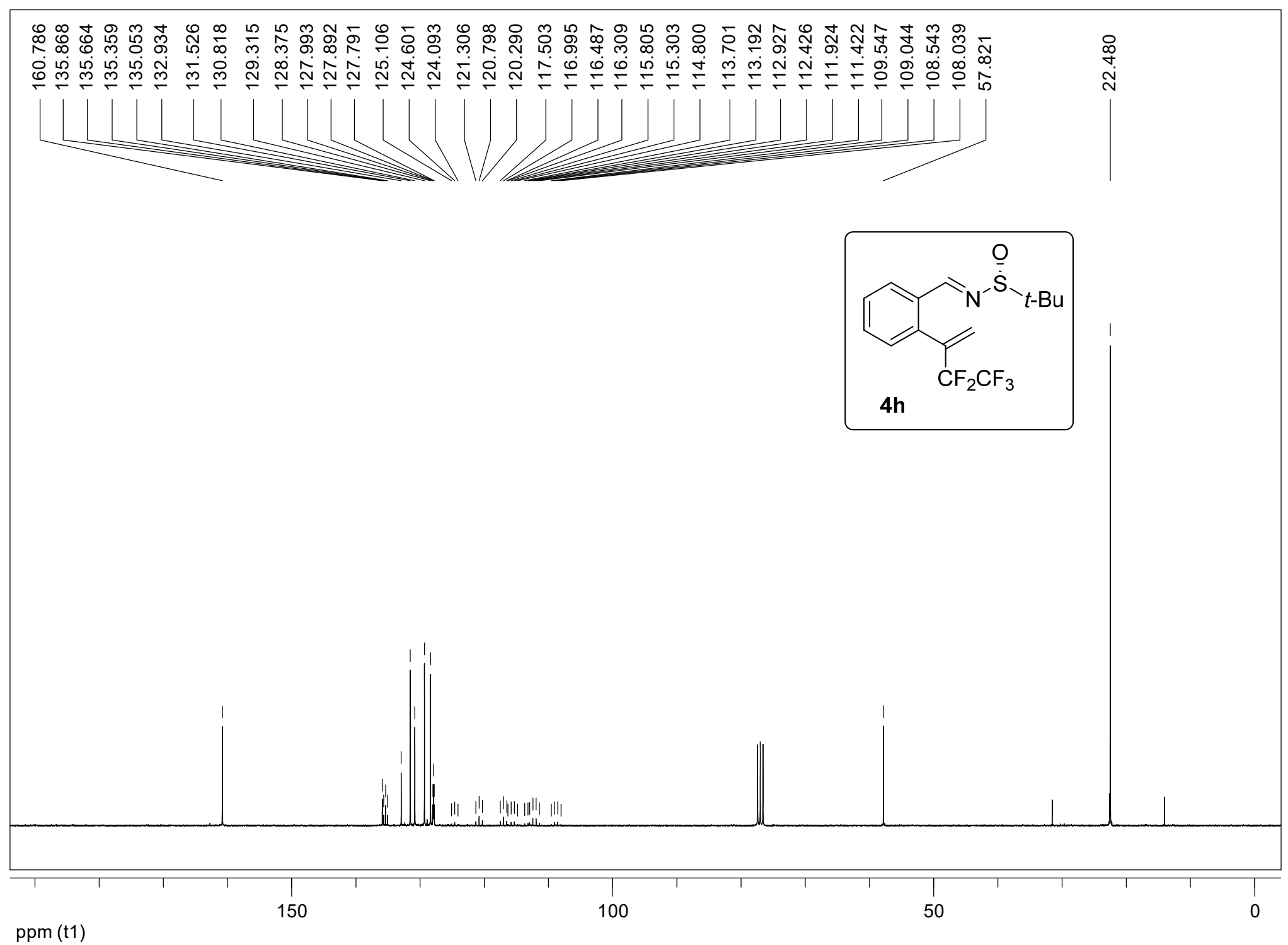




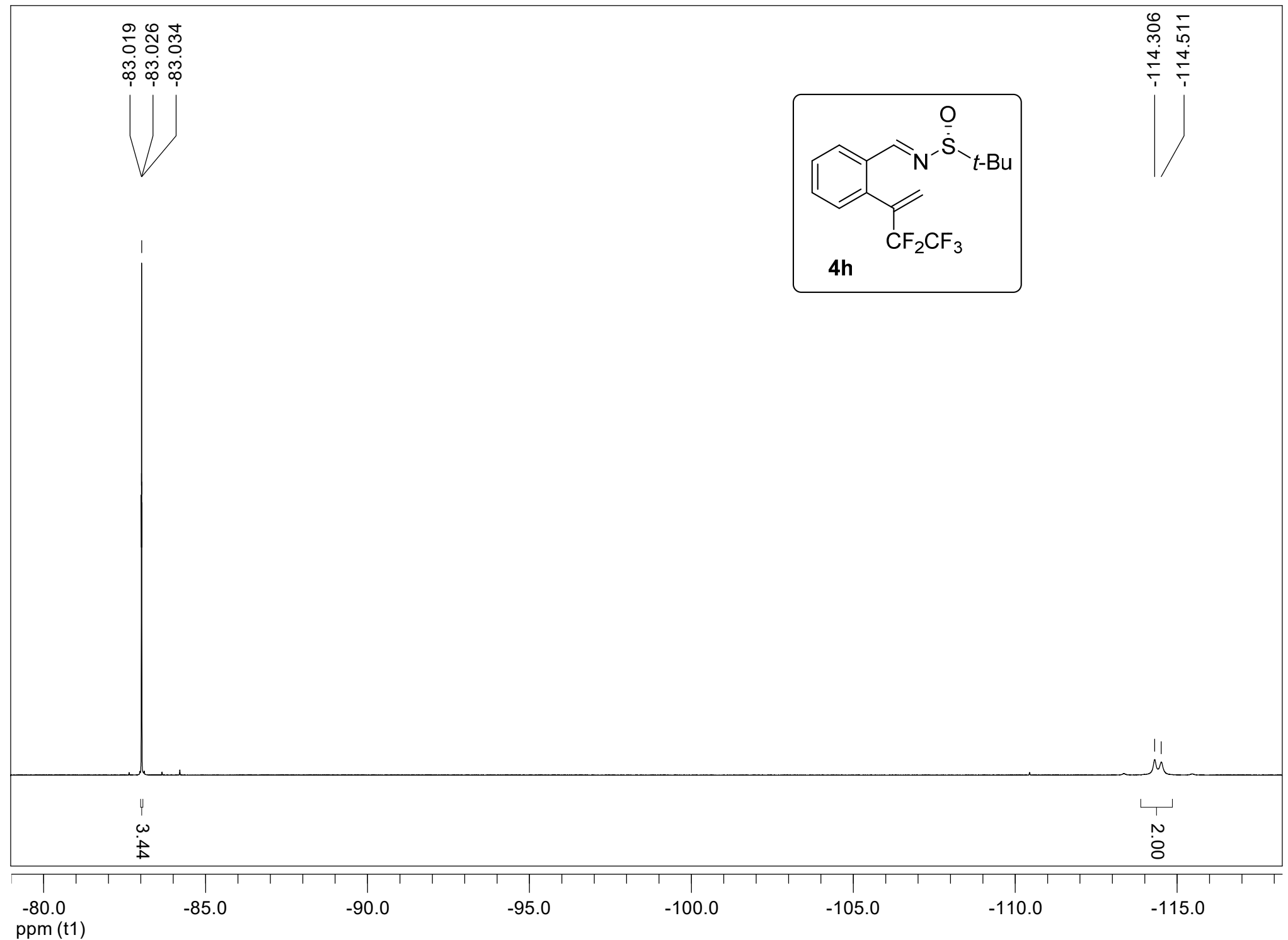




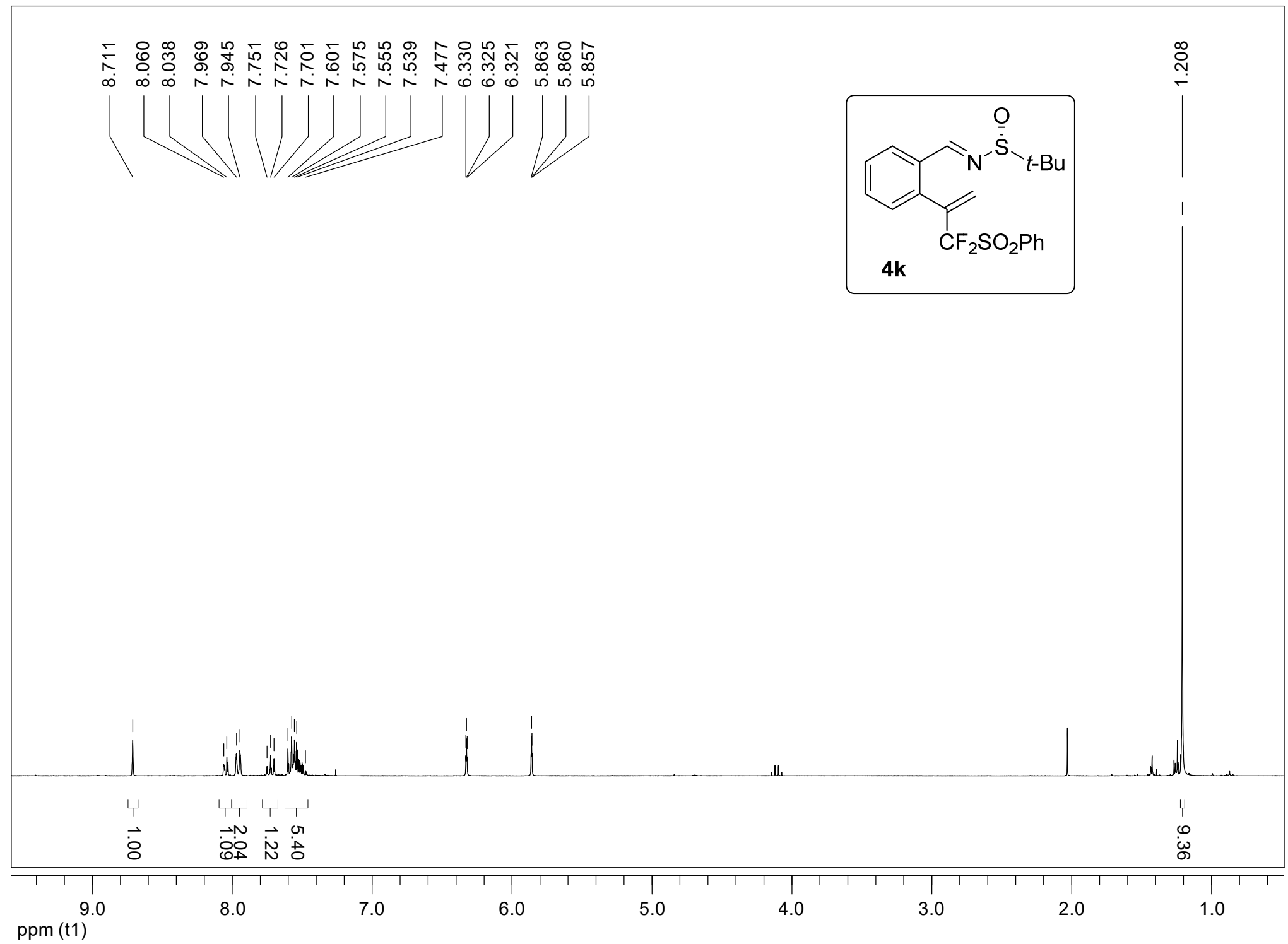




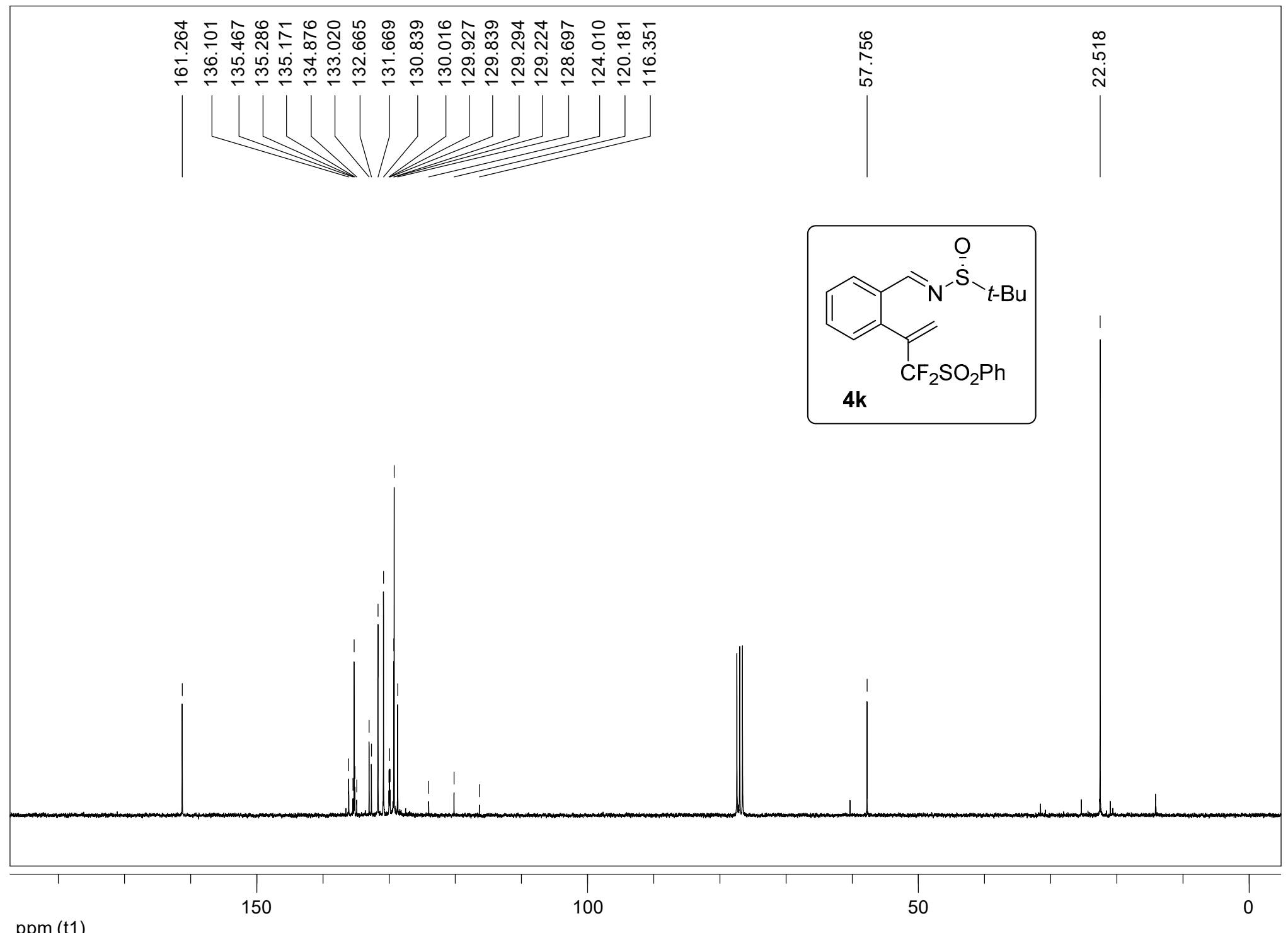

ppm (t1) 


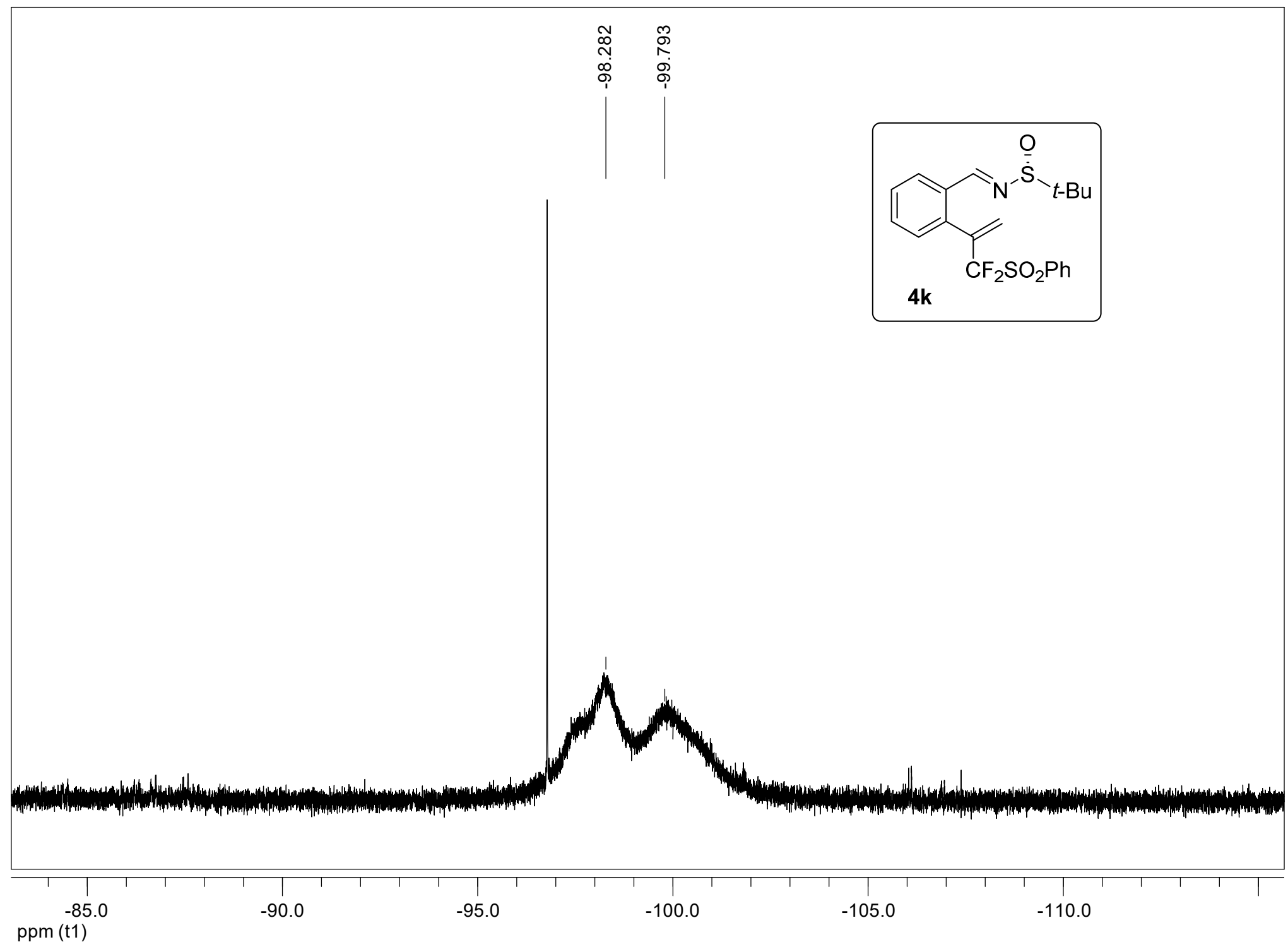




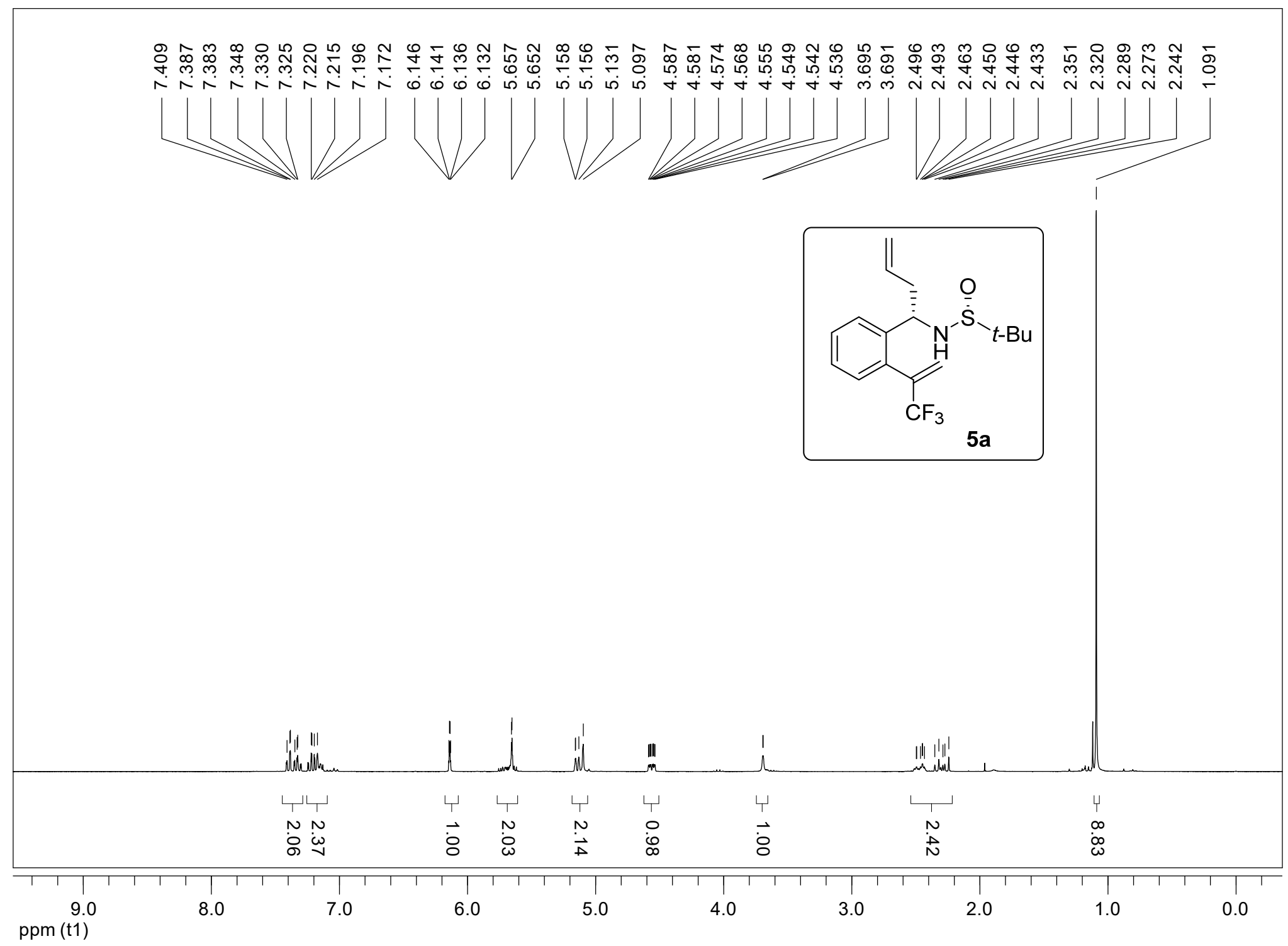




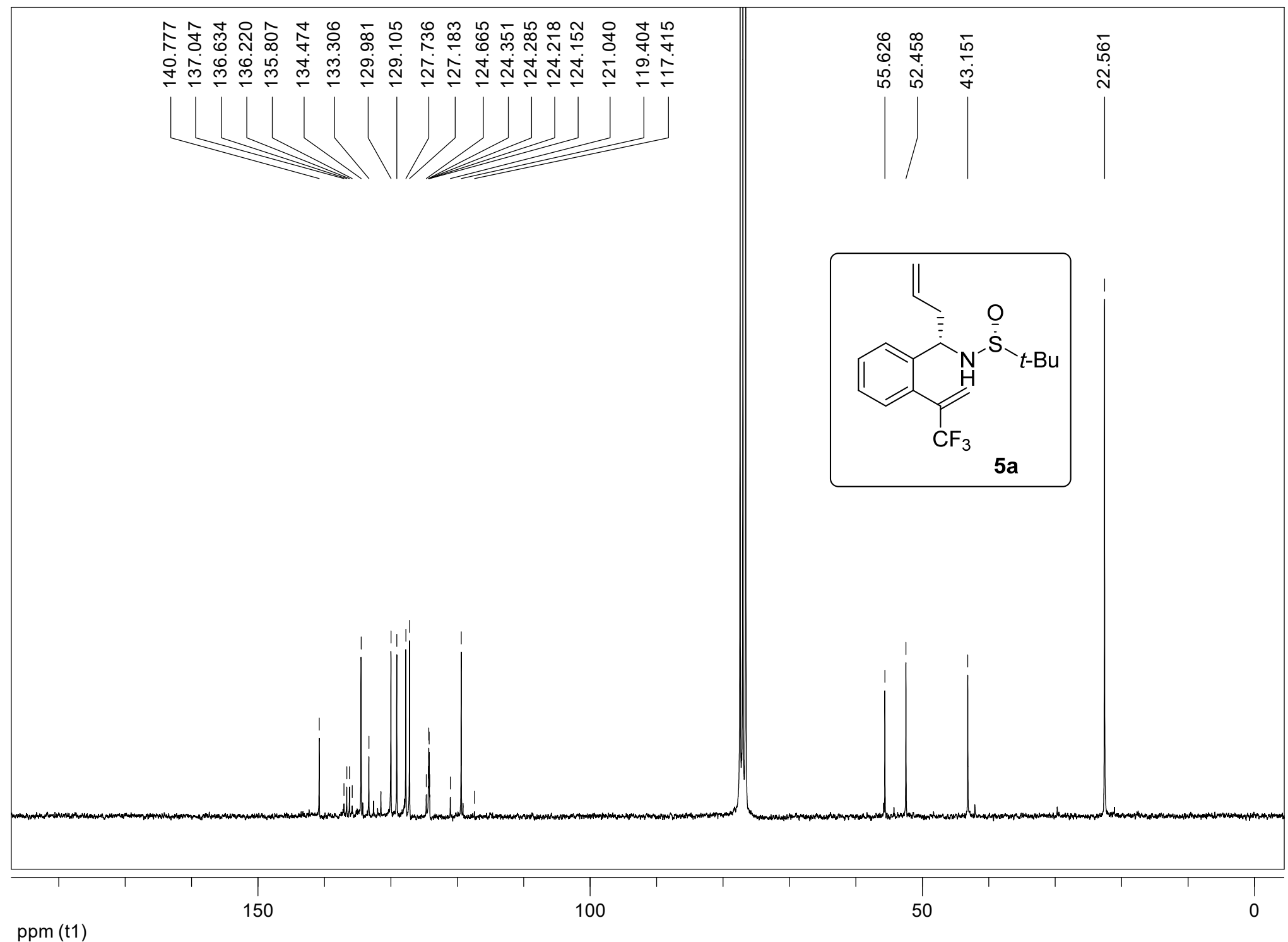




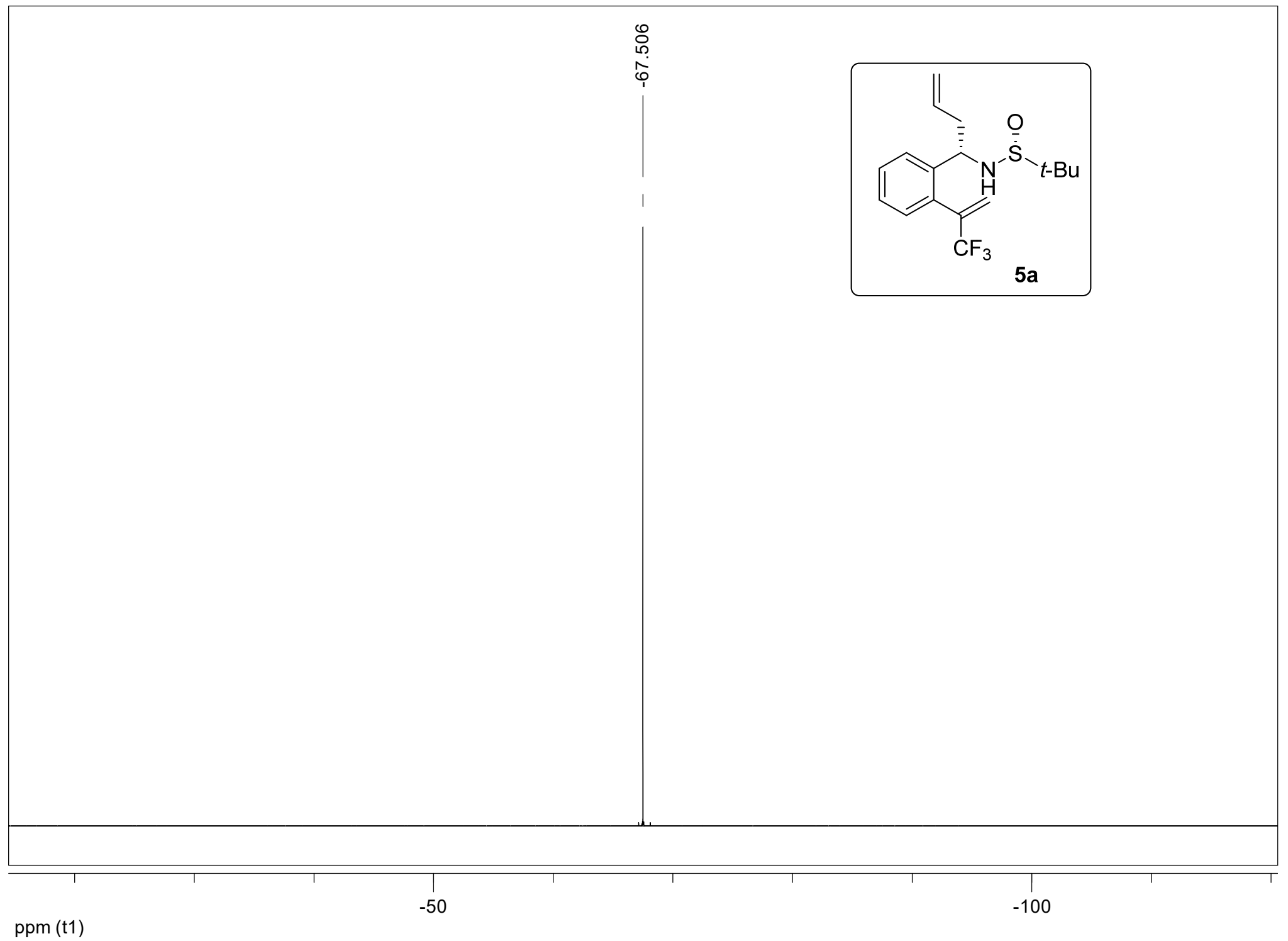




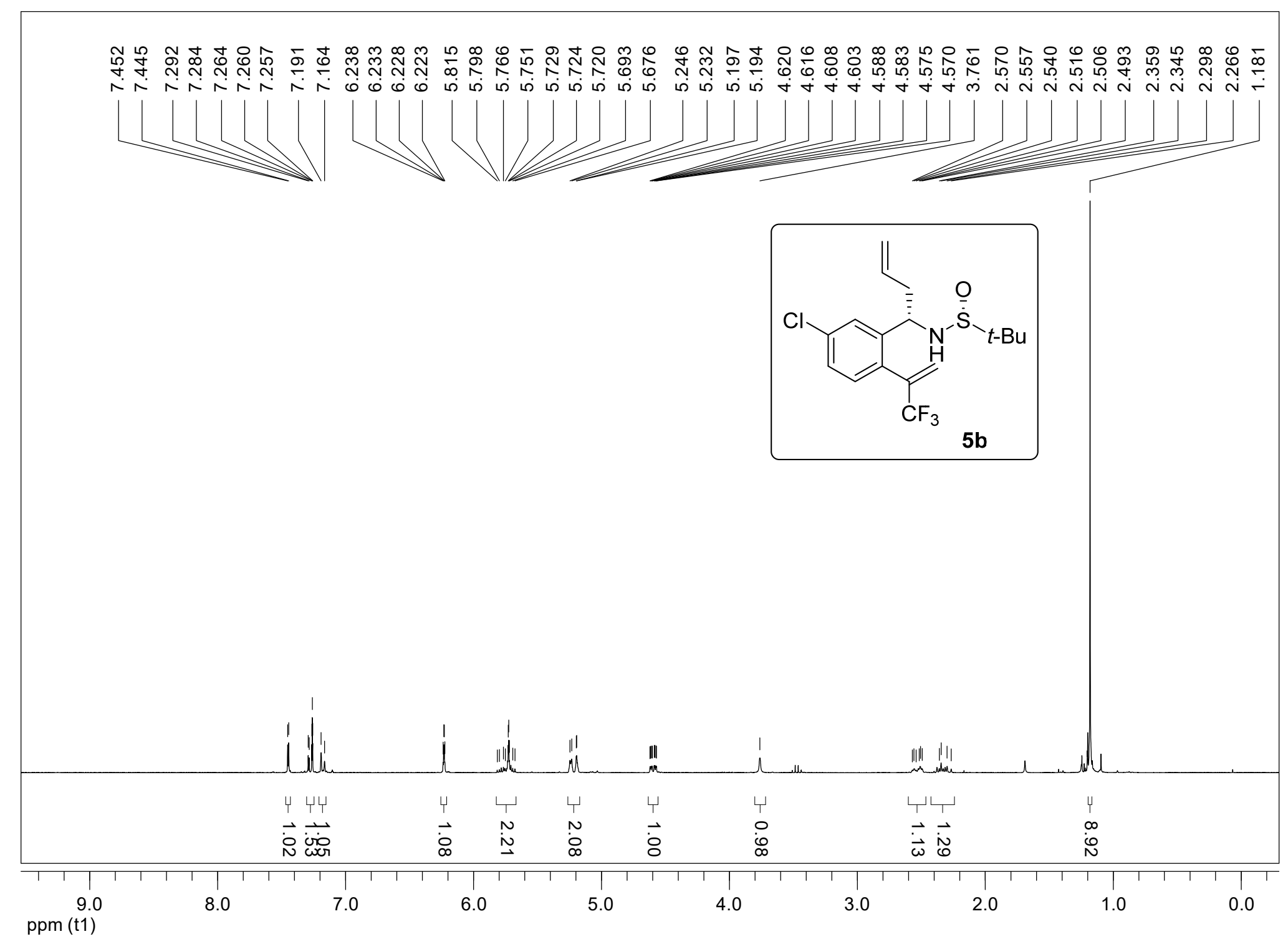




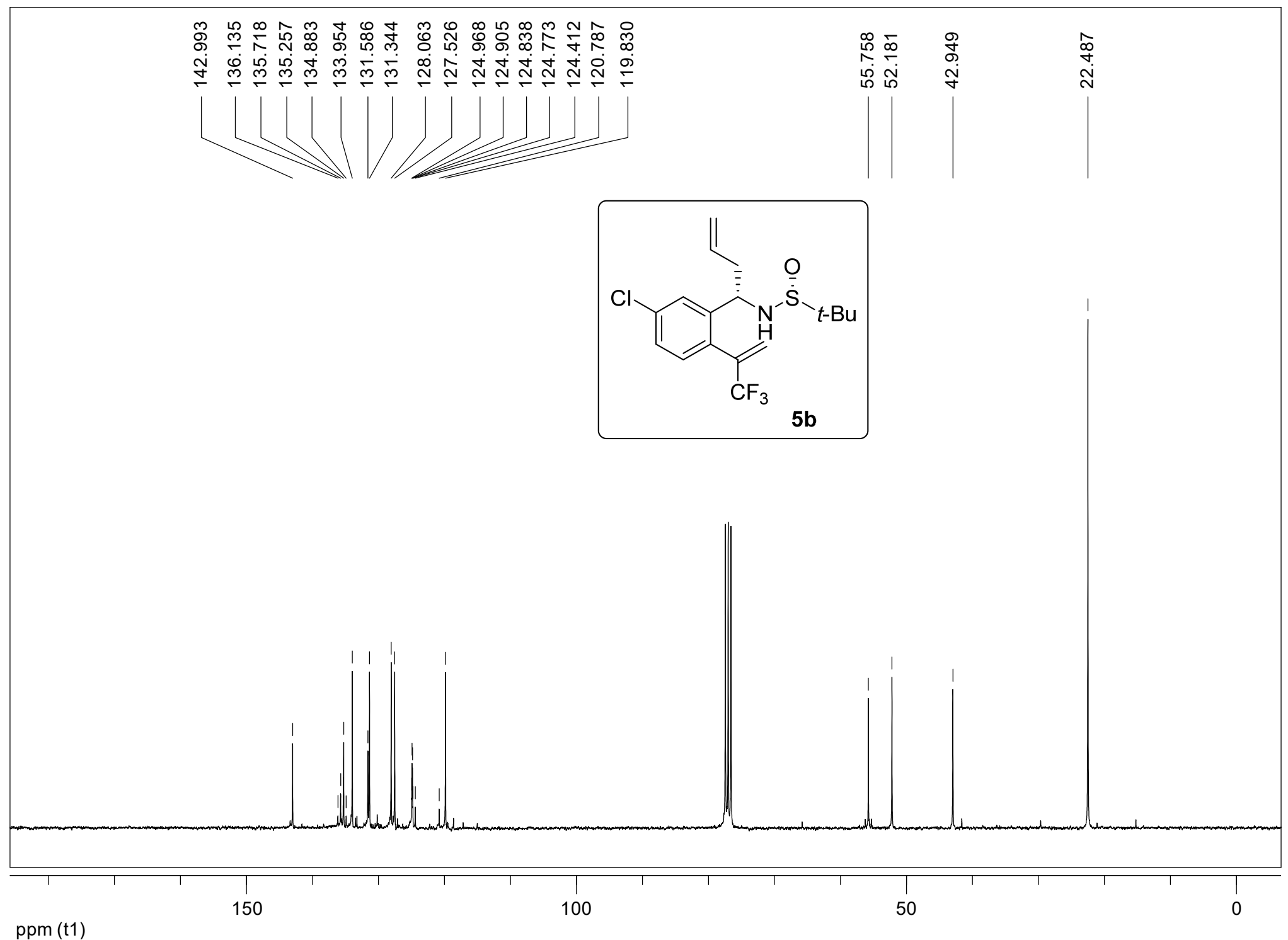




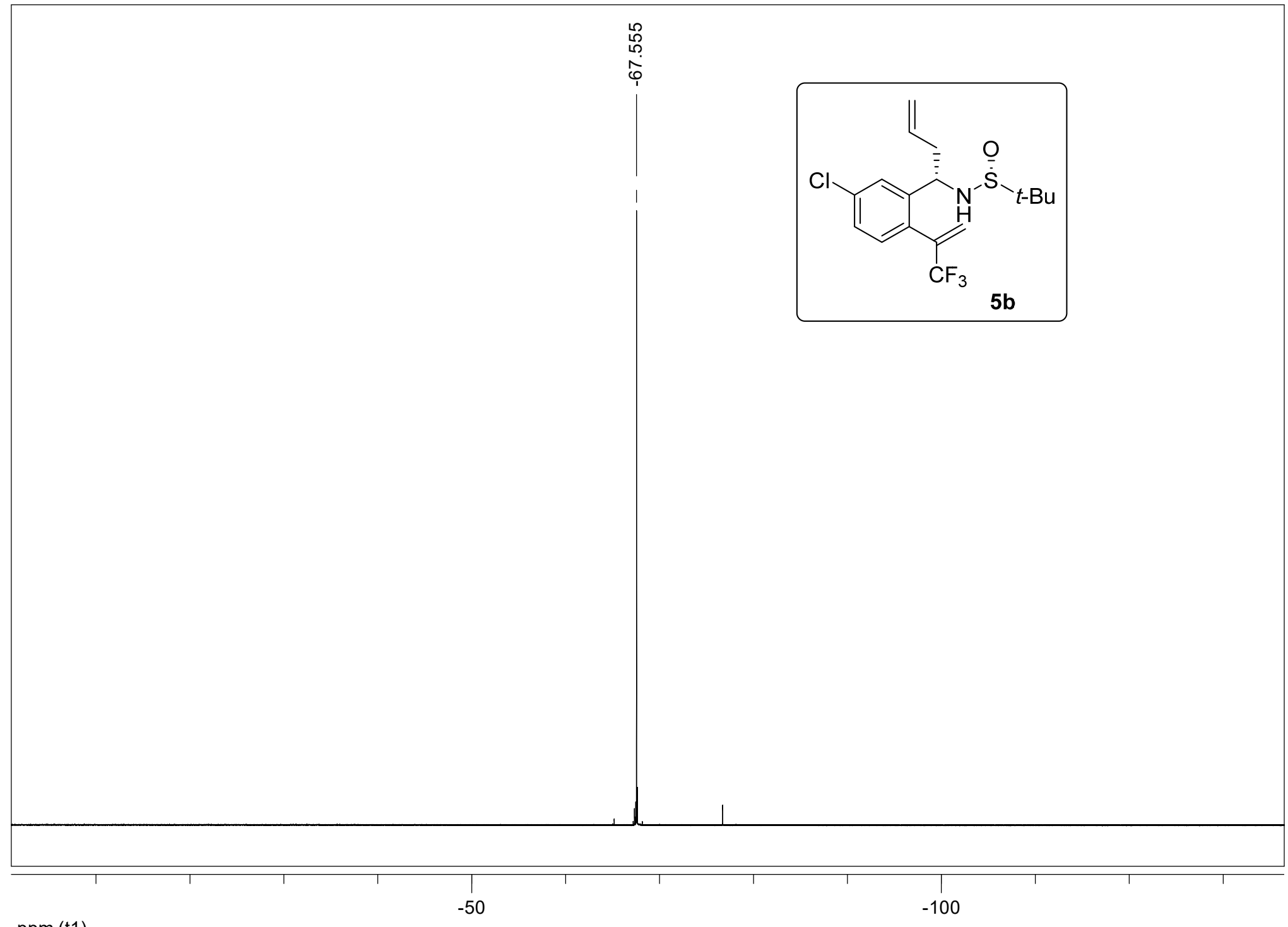

ppm (t1) 


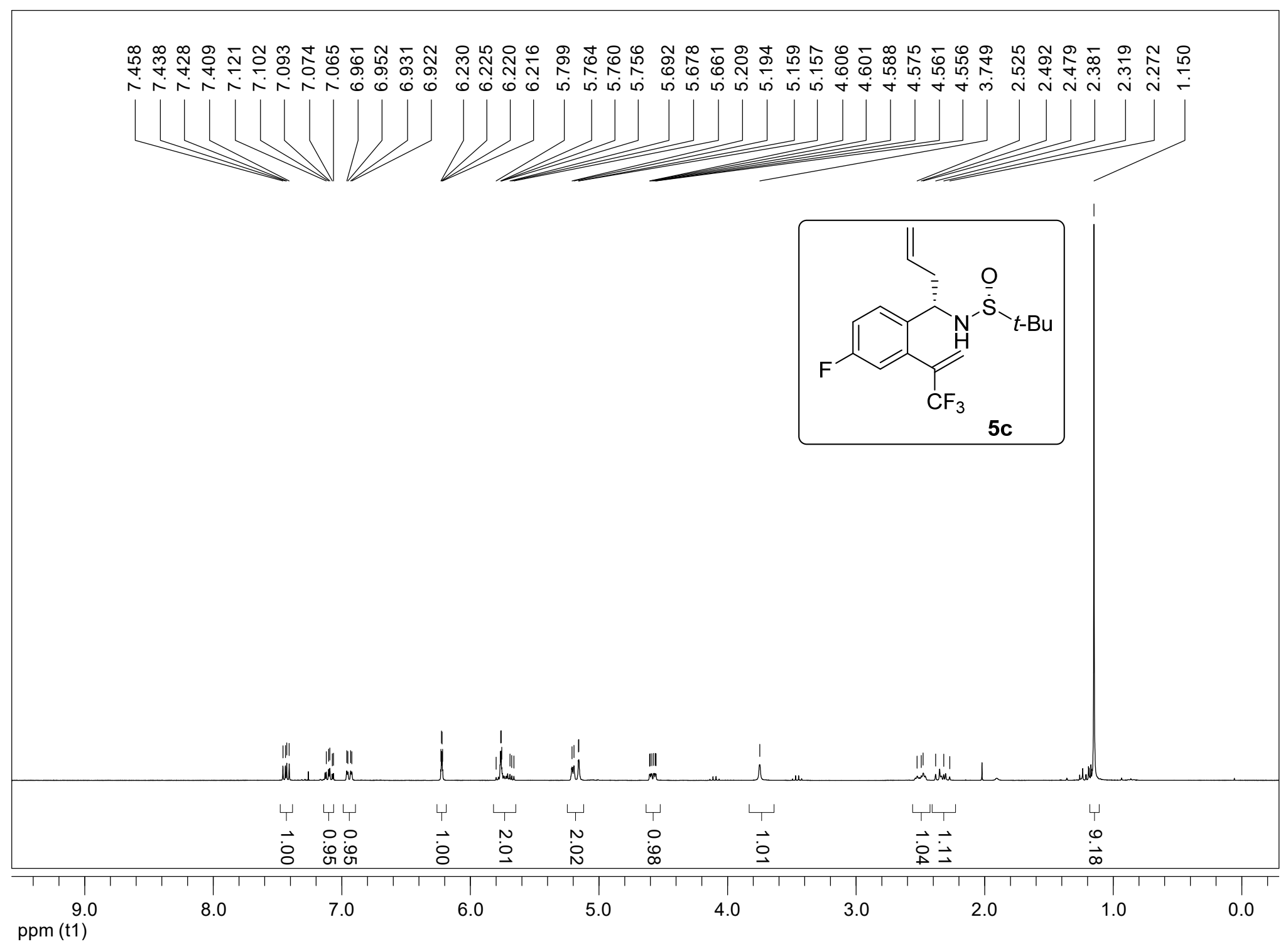




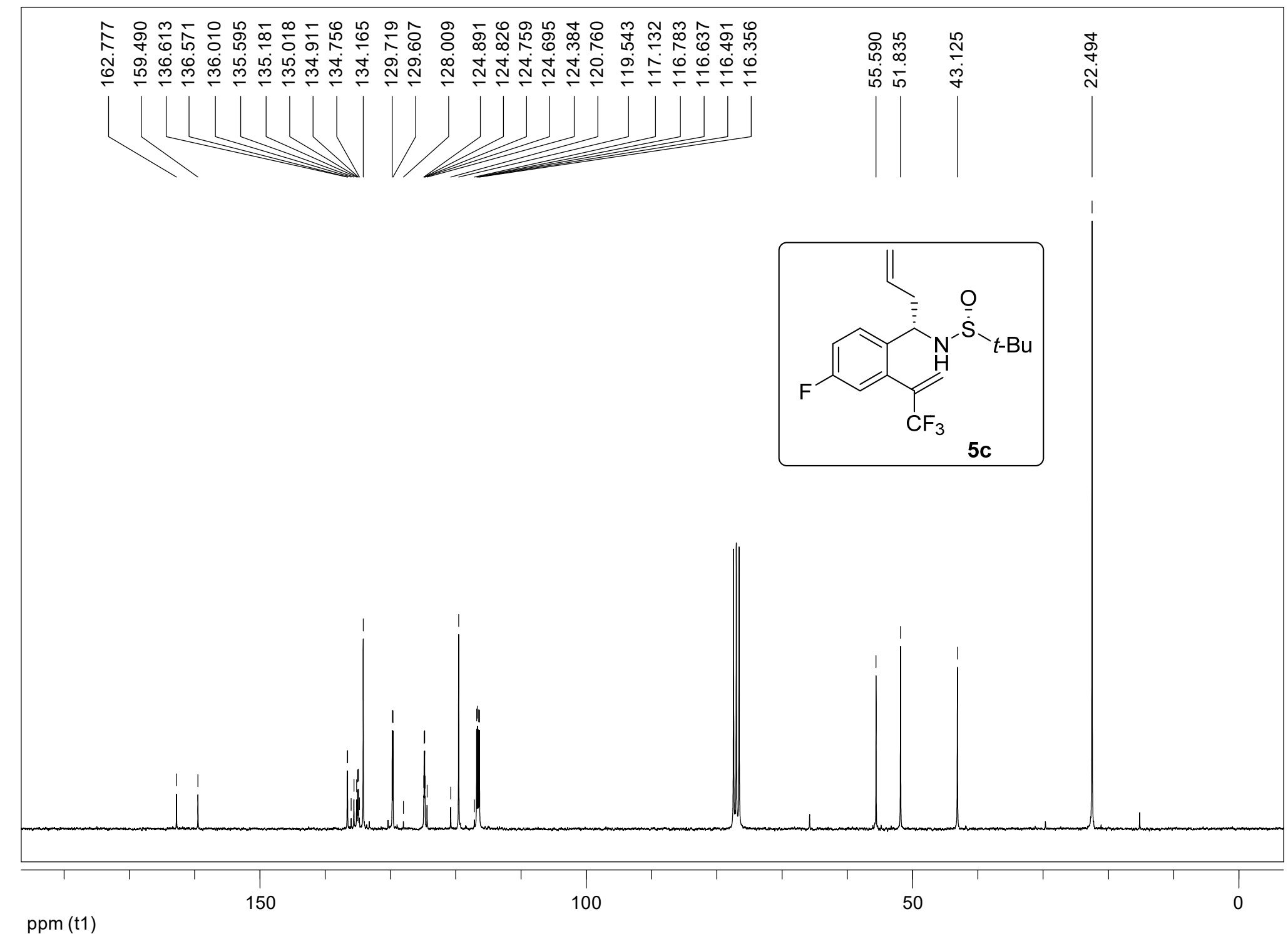




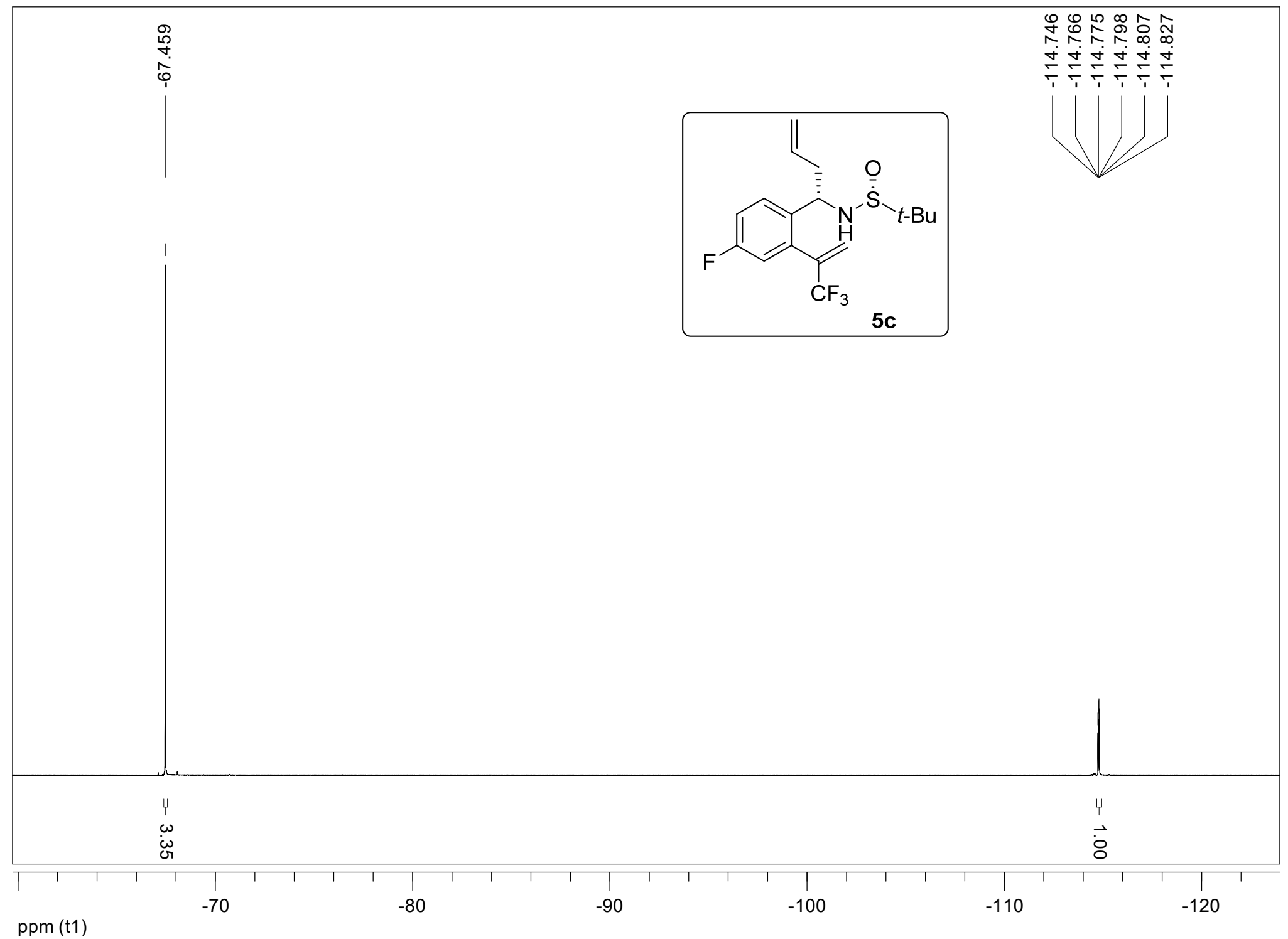




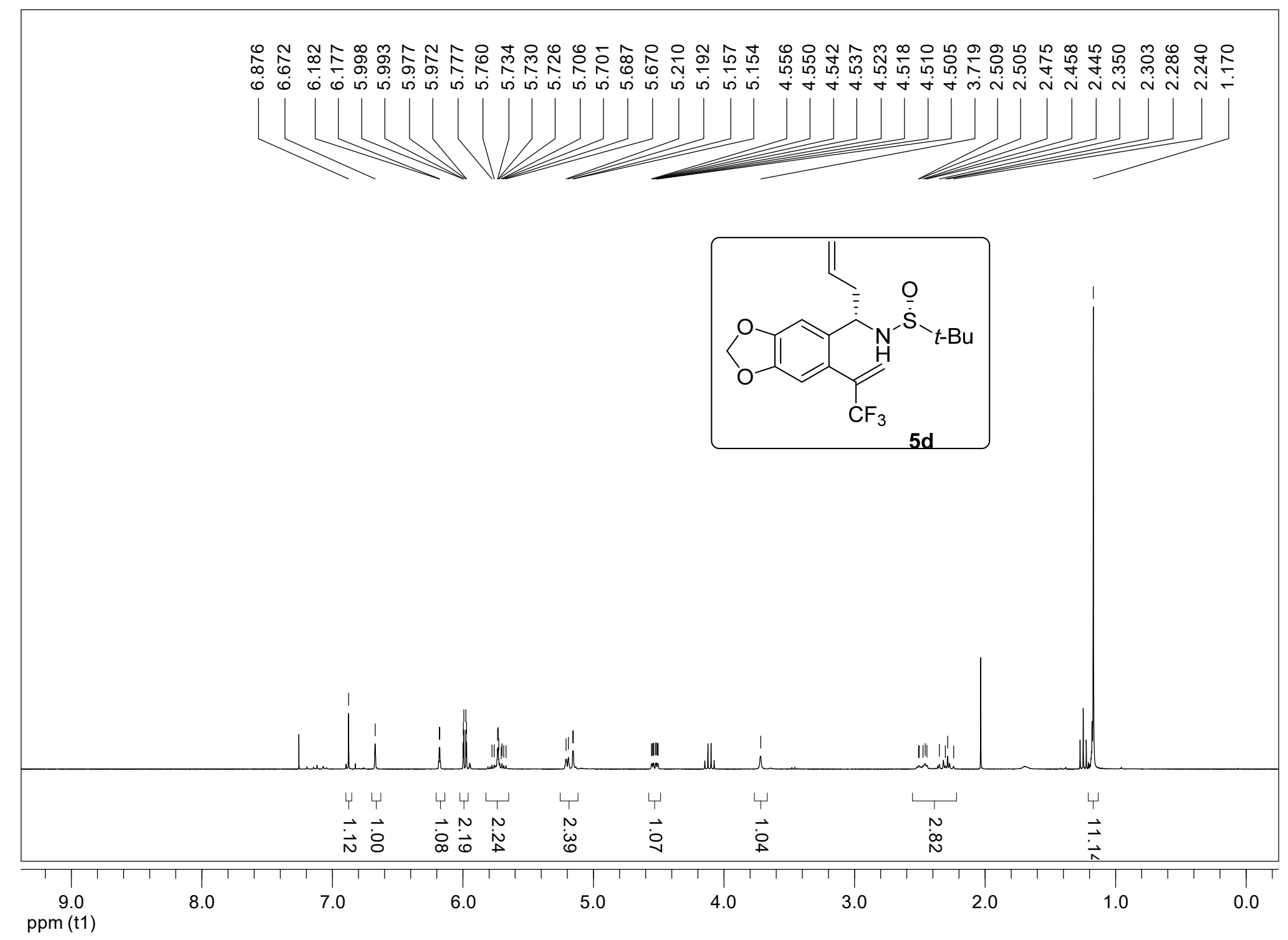




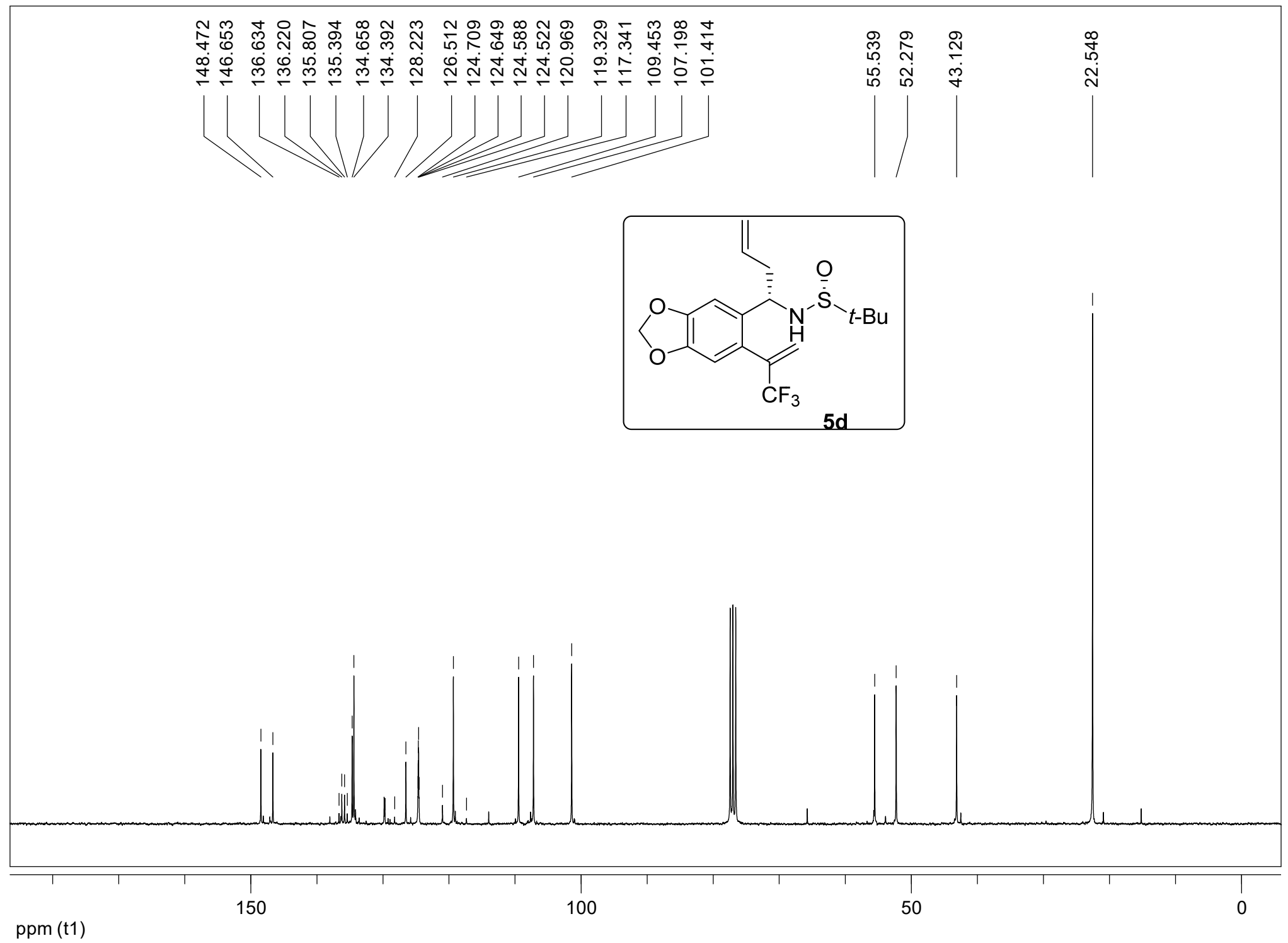




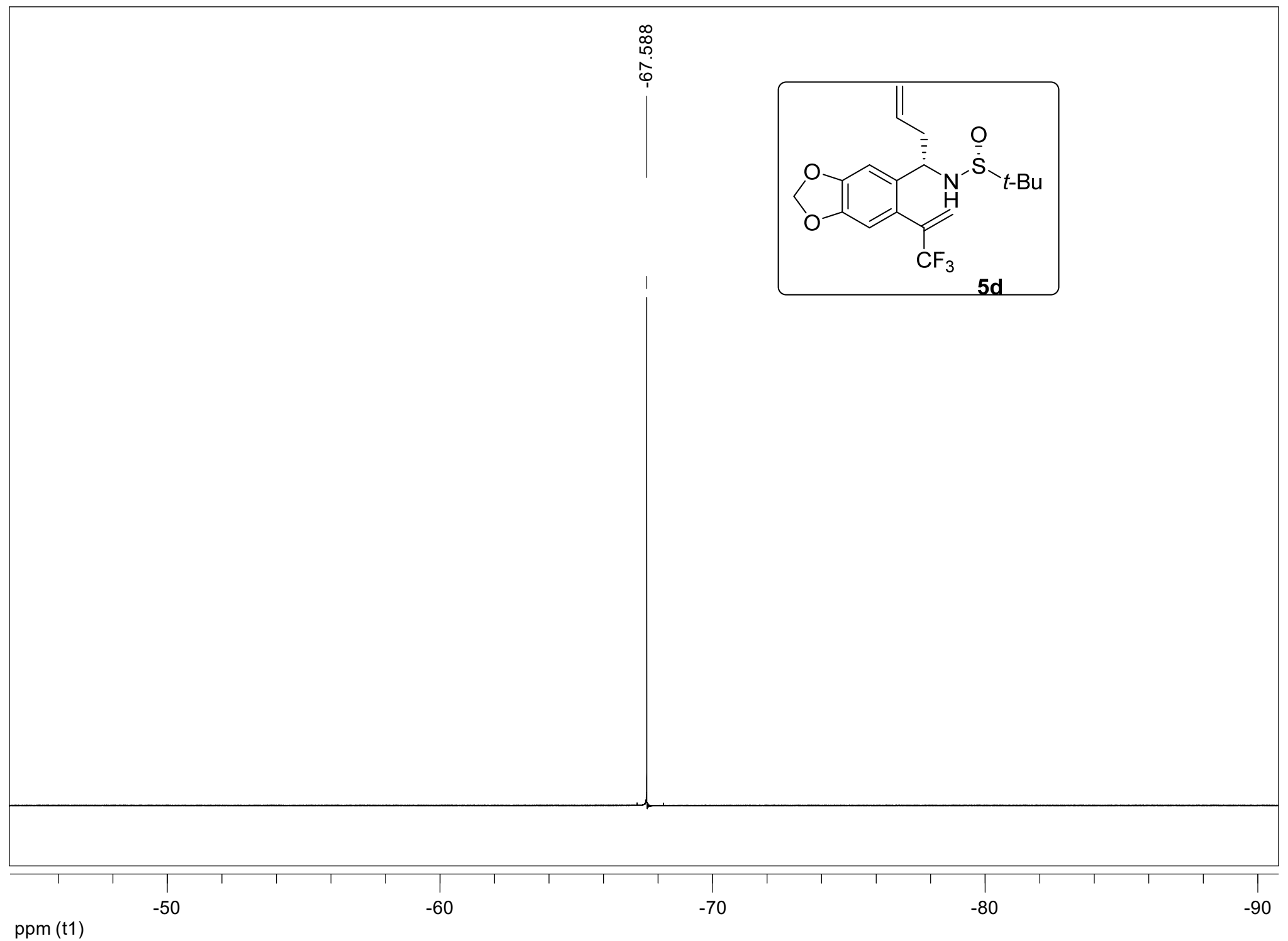




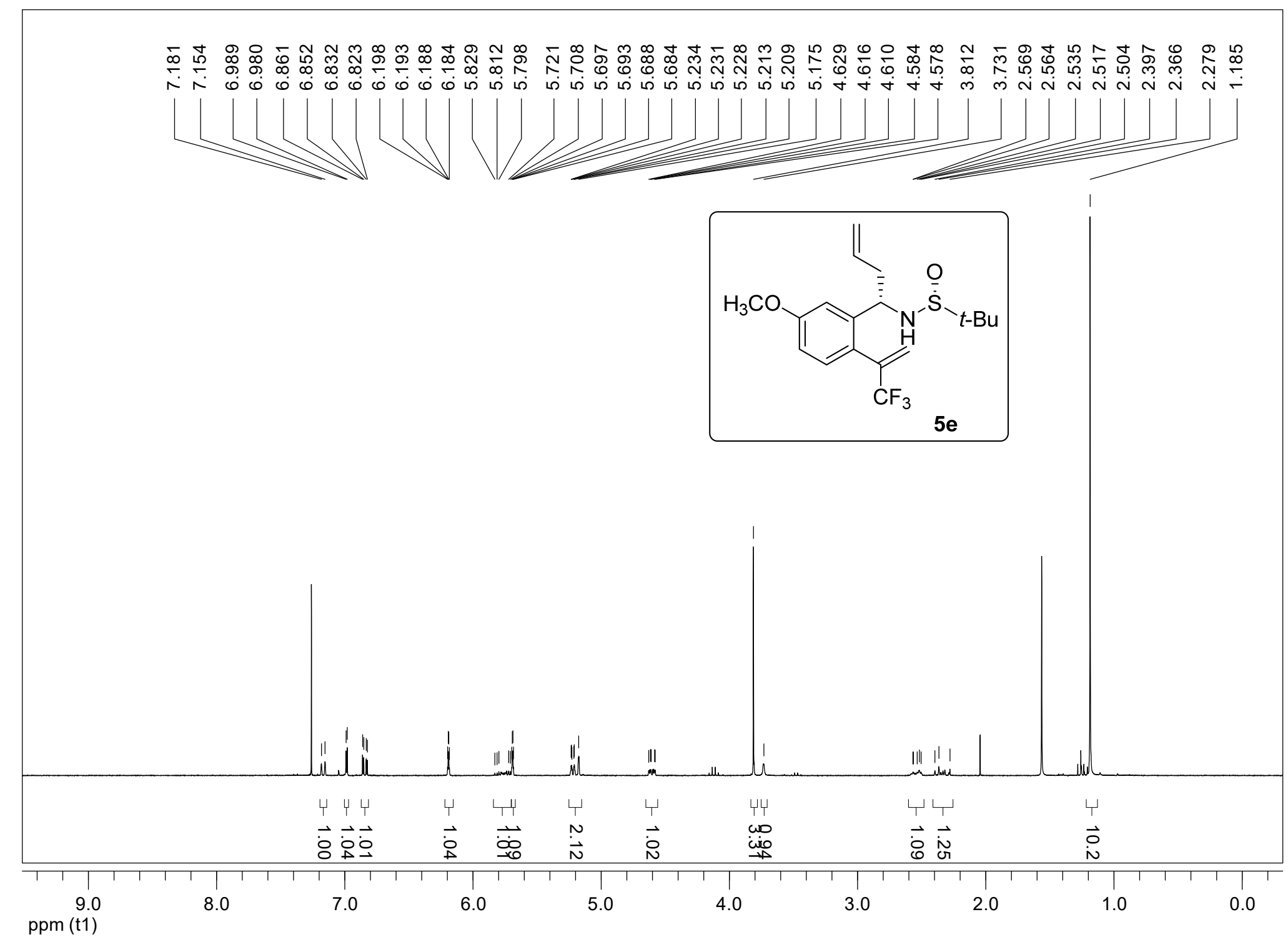




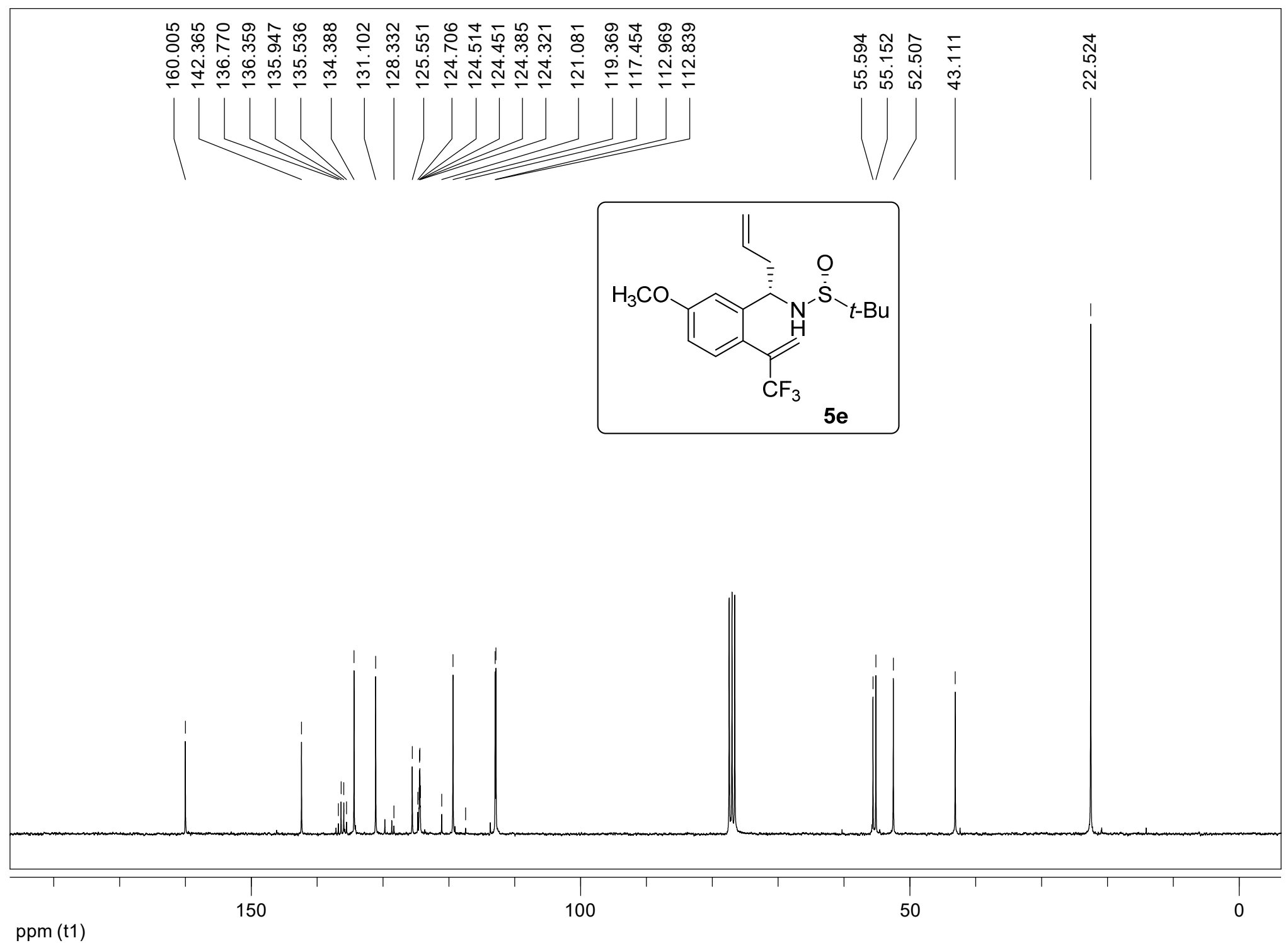




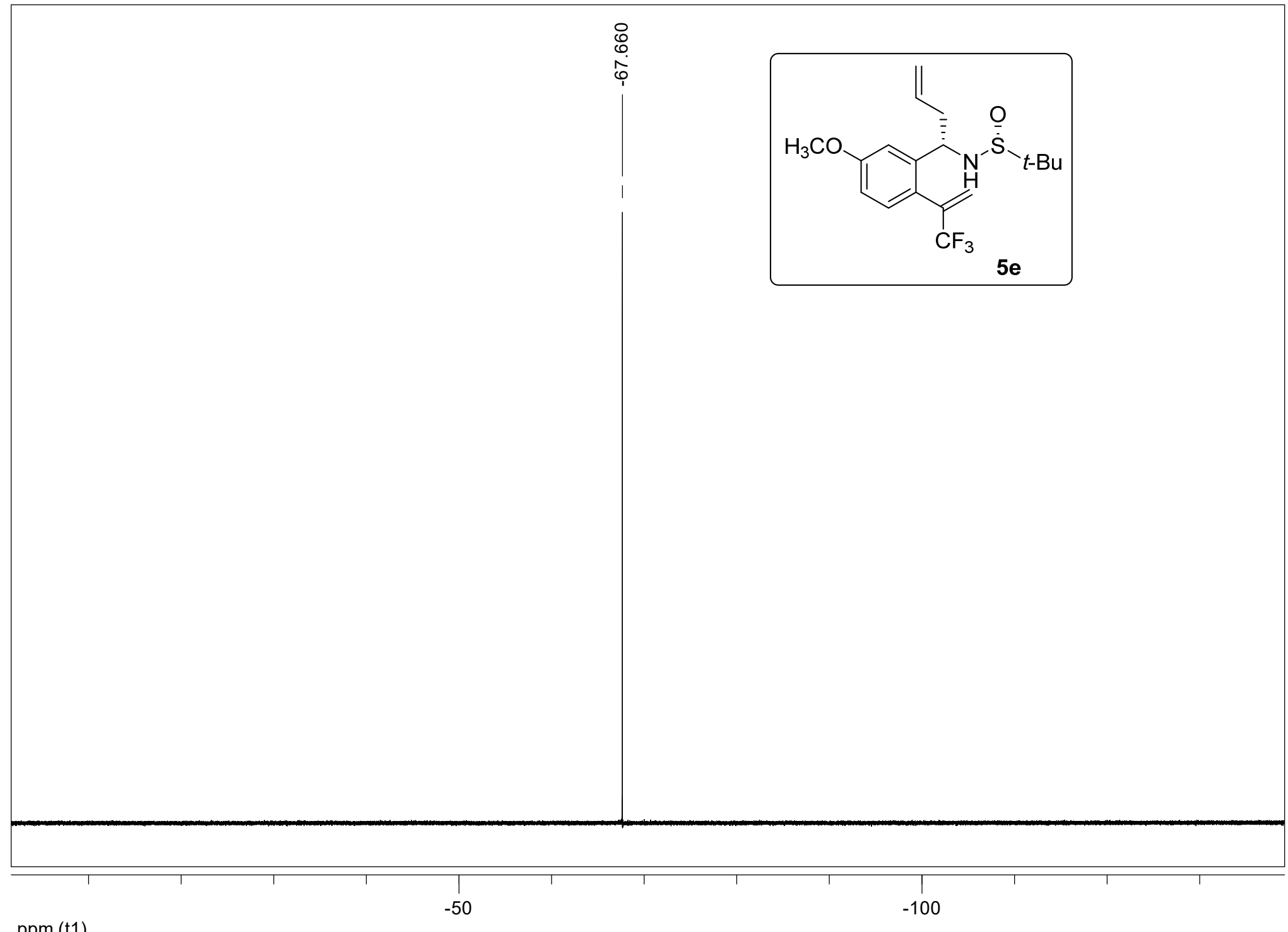

ppm (t1) 


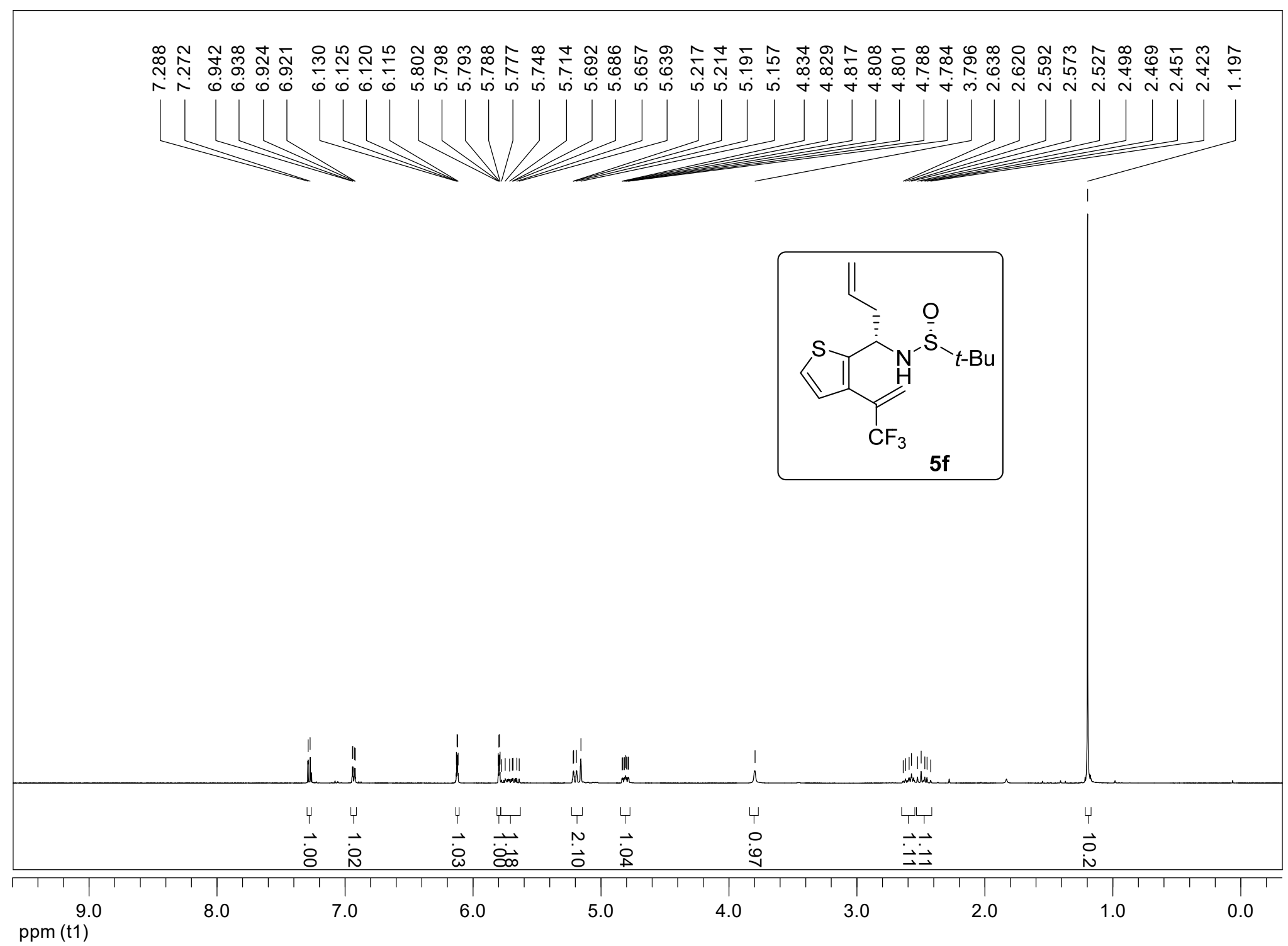




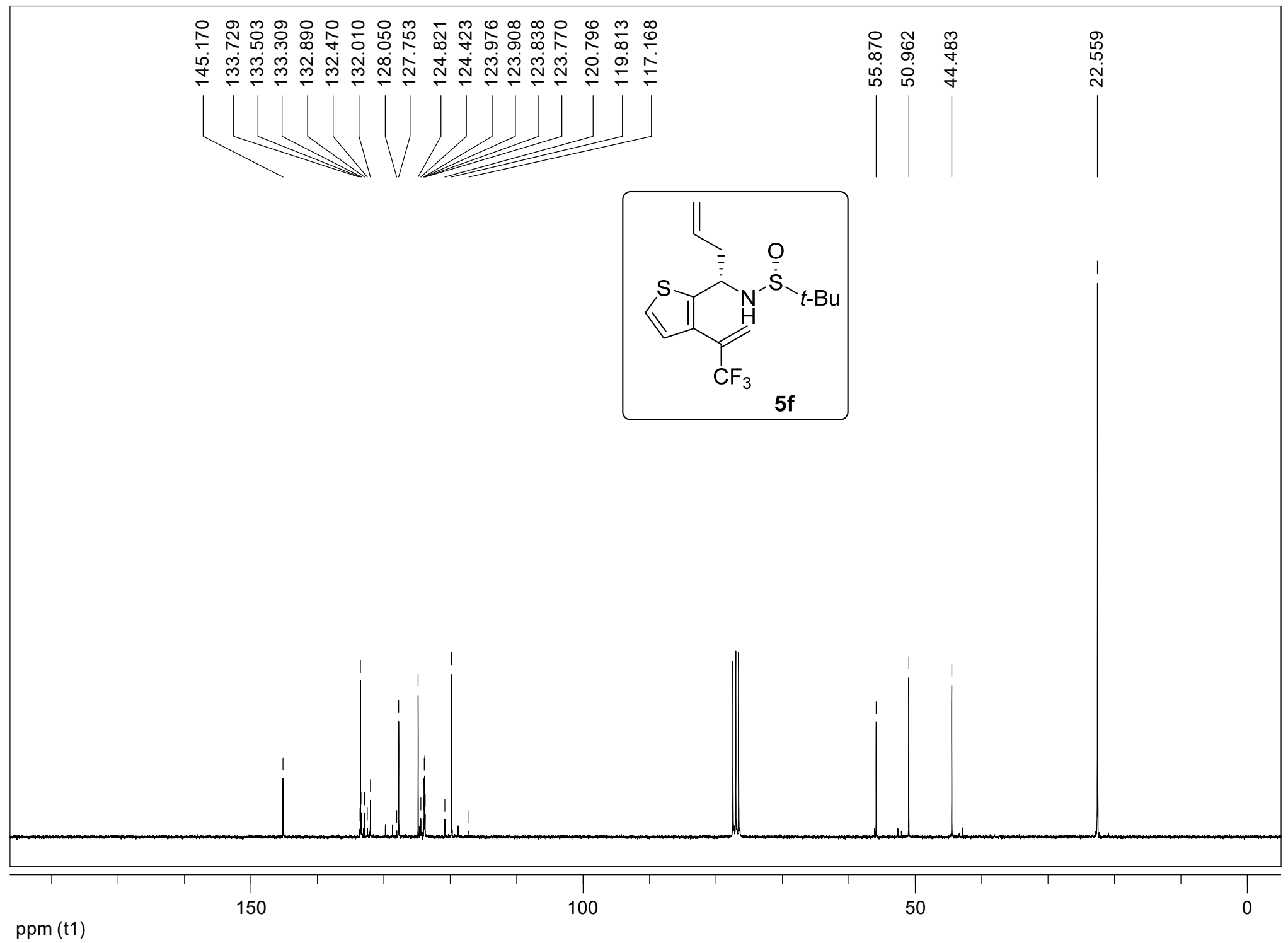




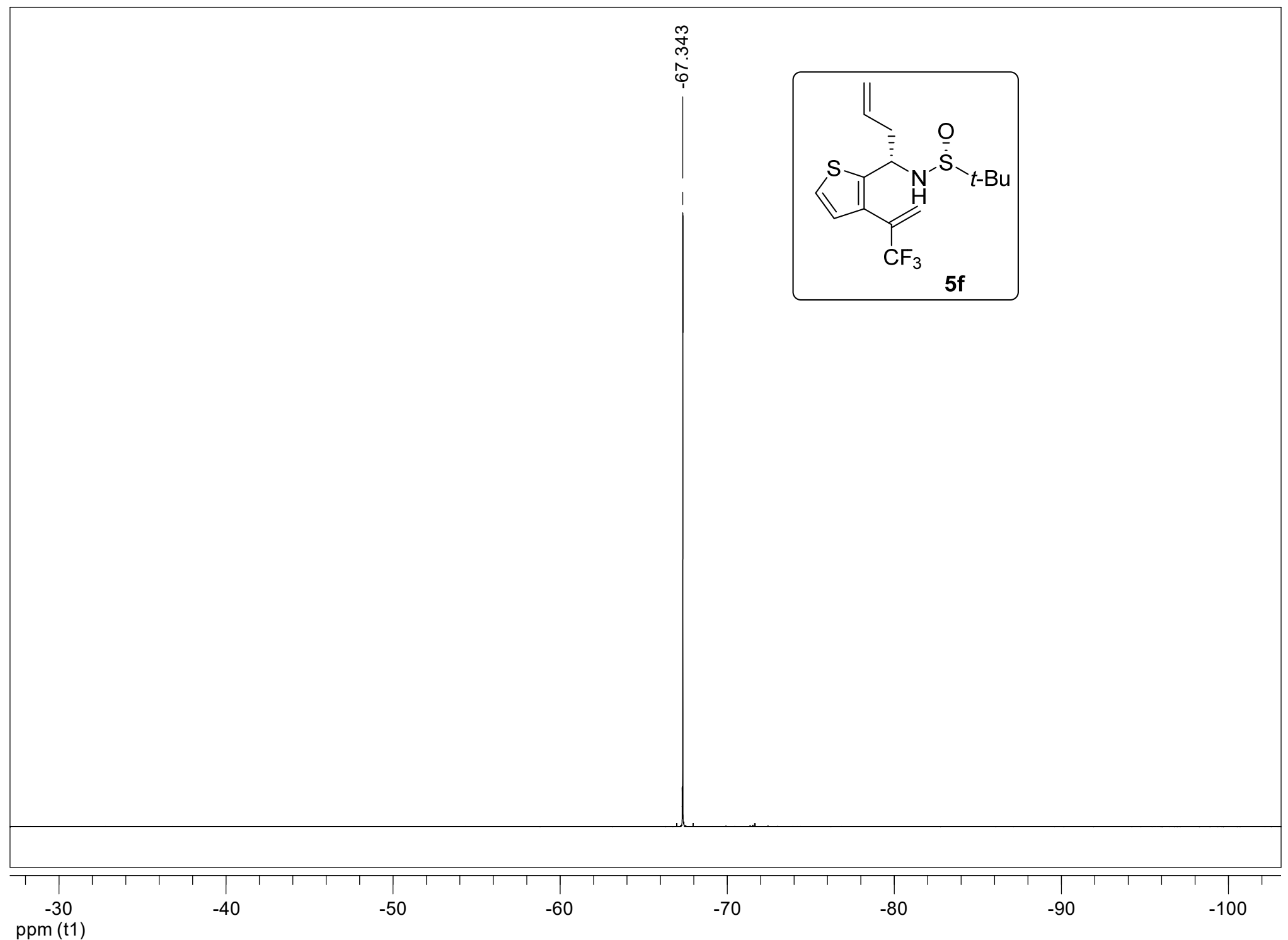




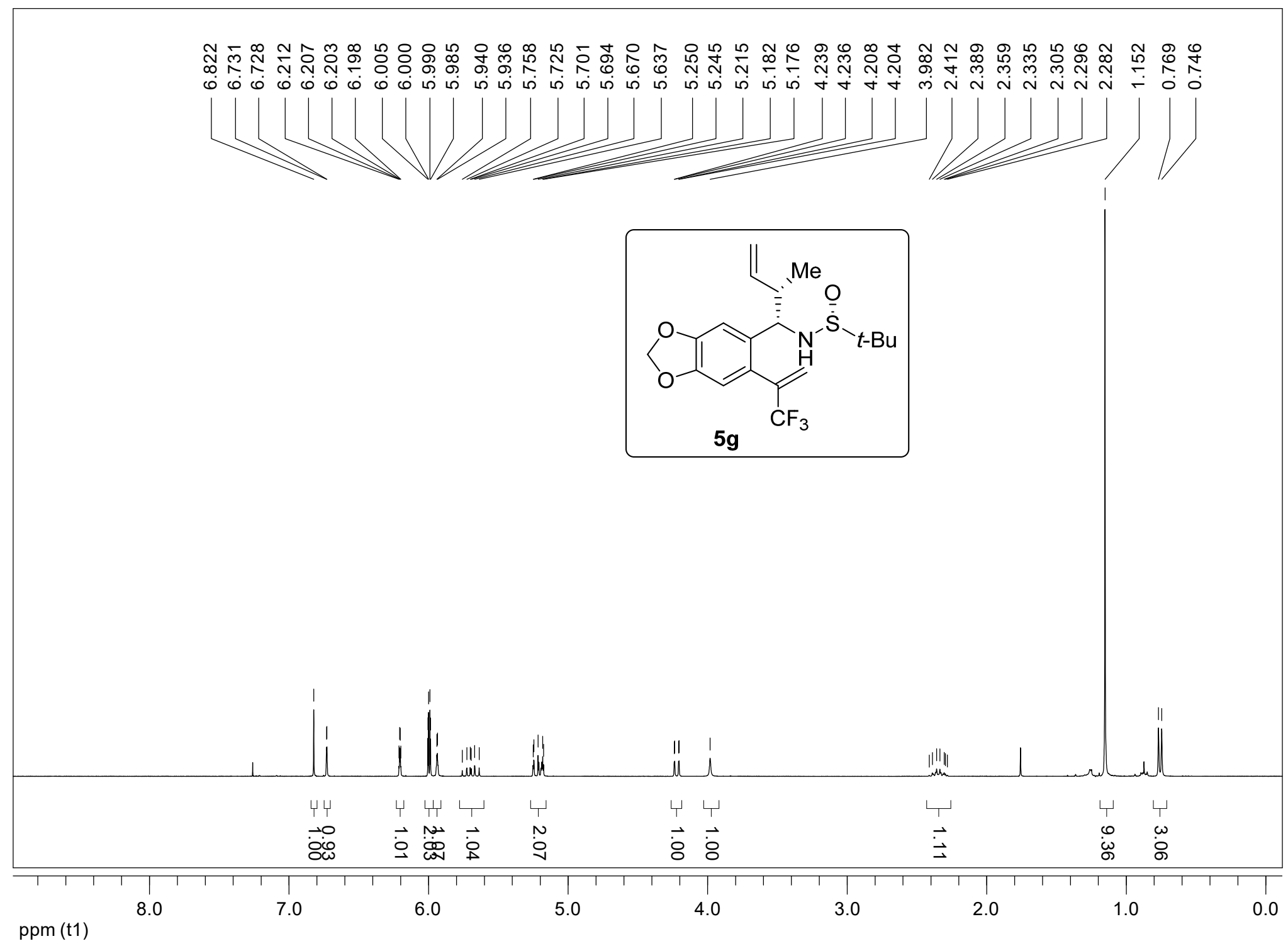




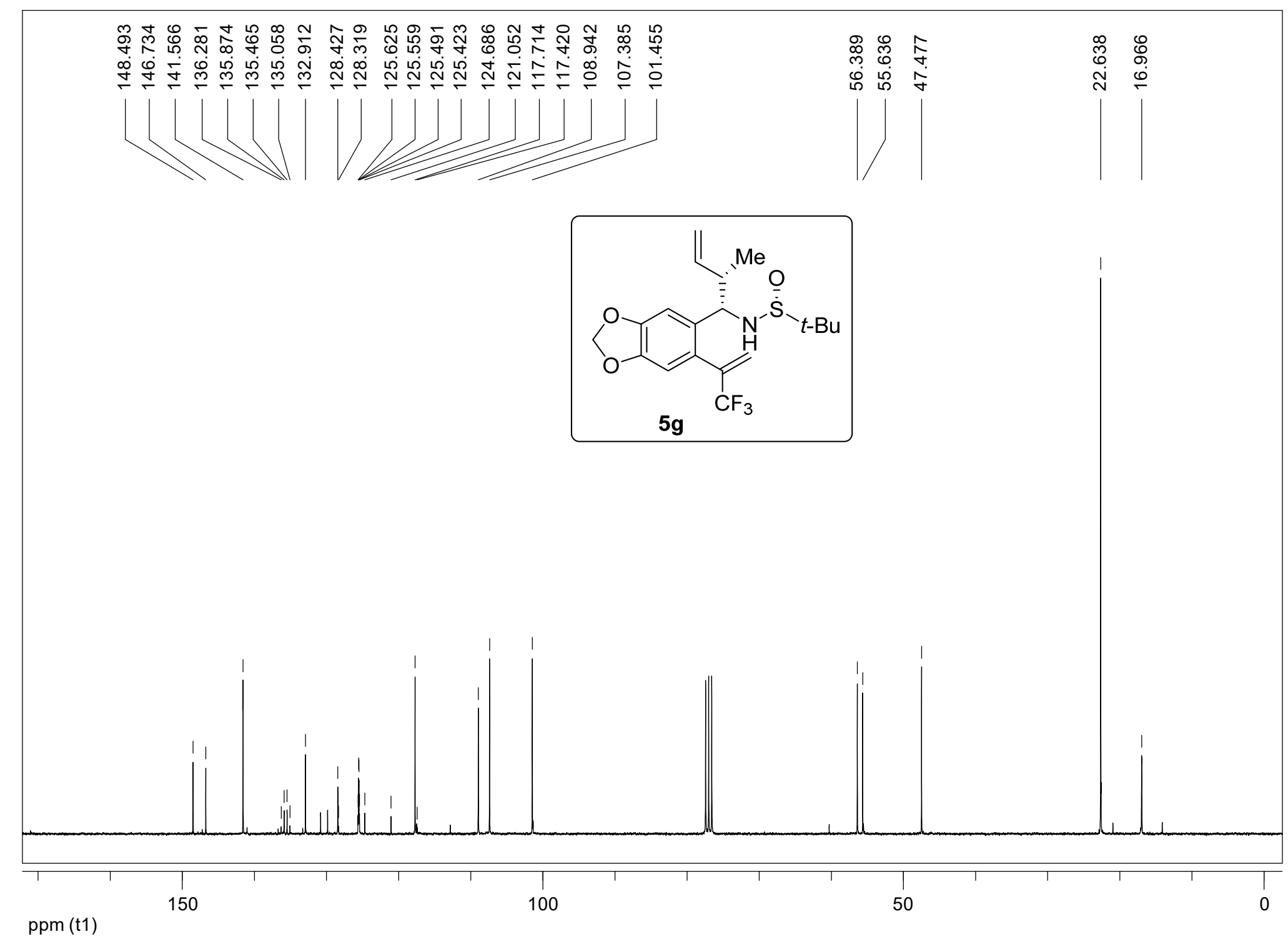




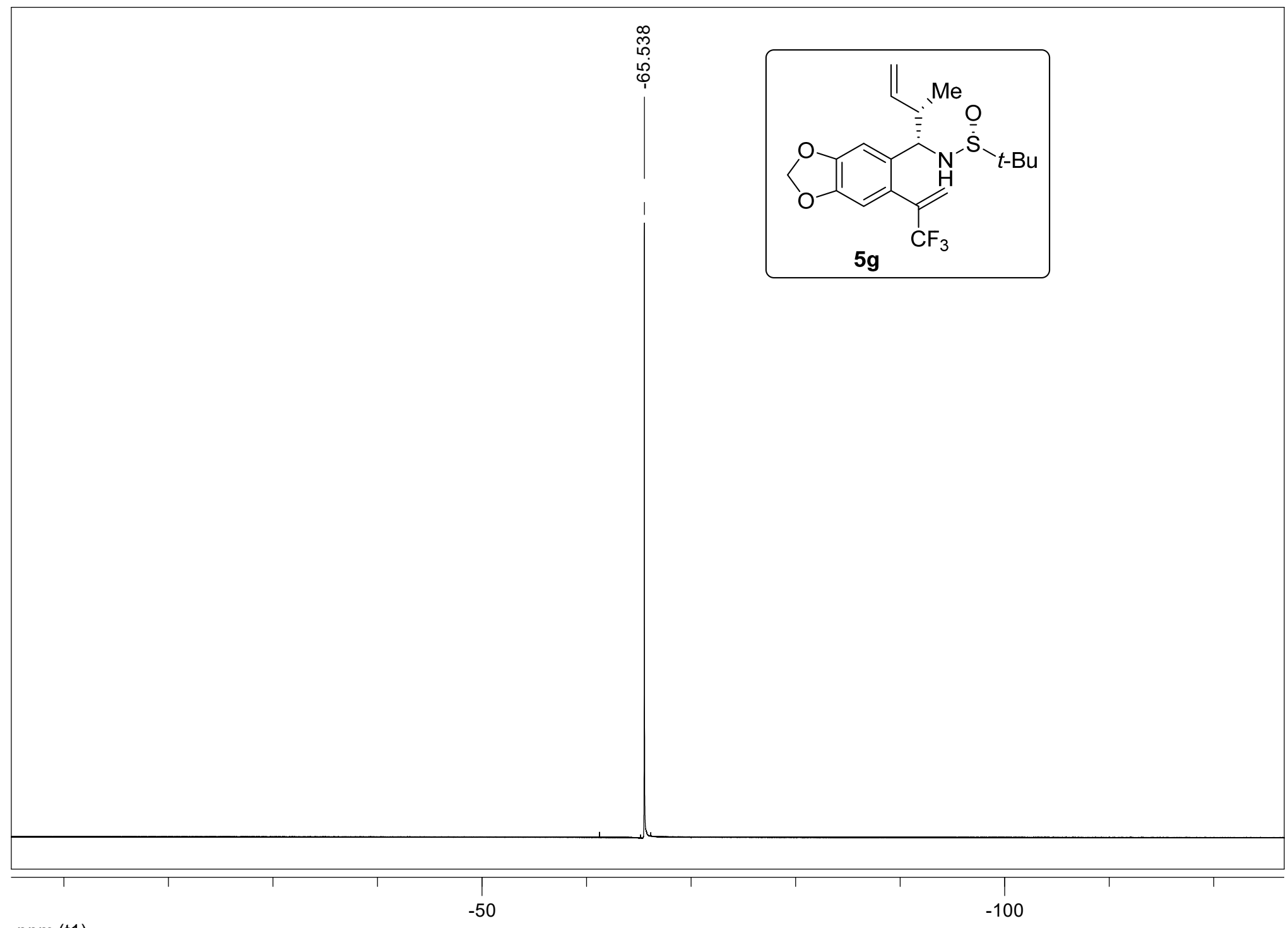

ppm (t1) 


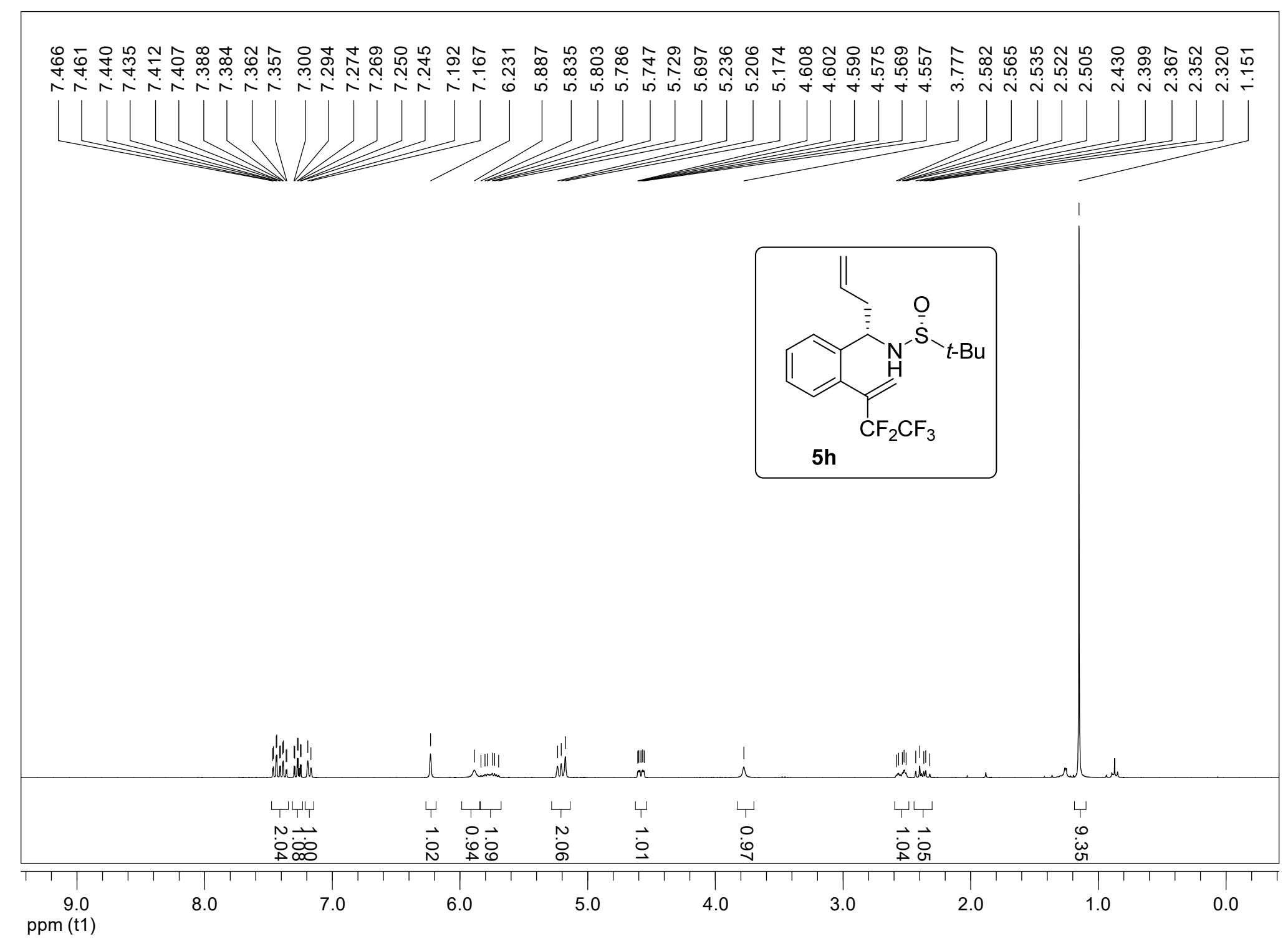




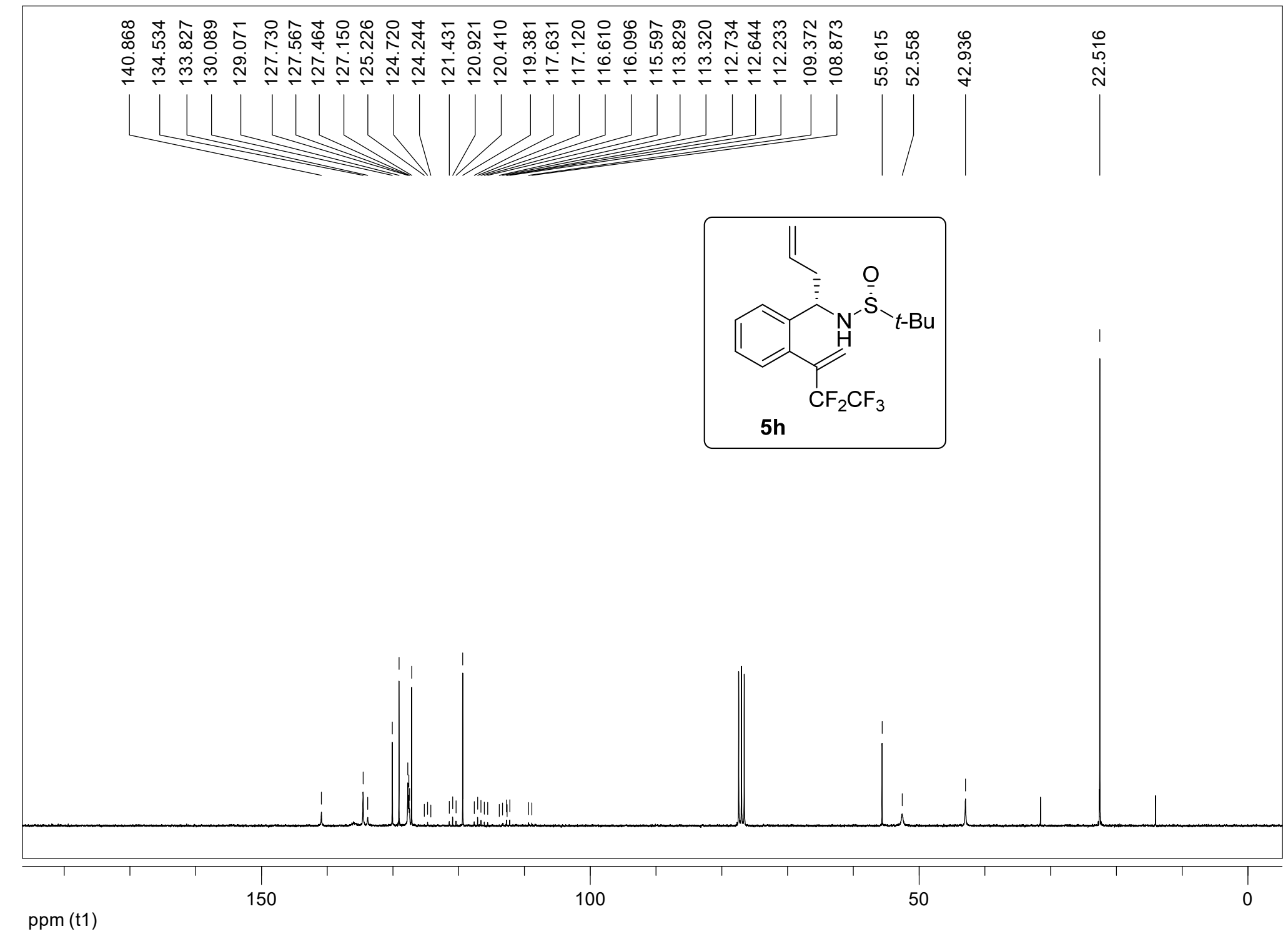




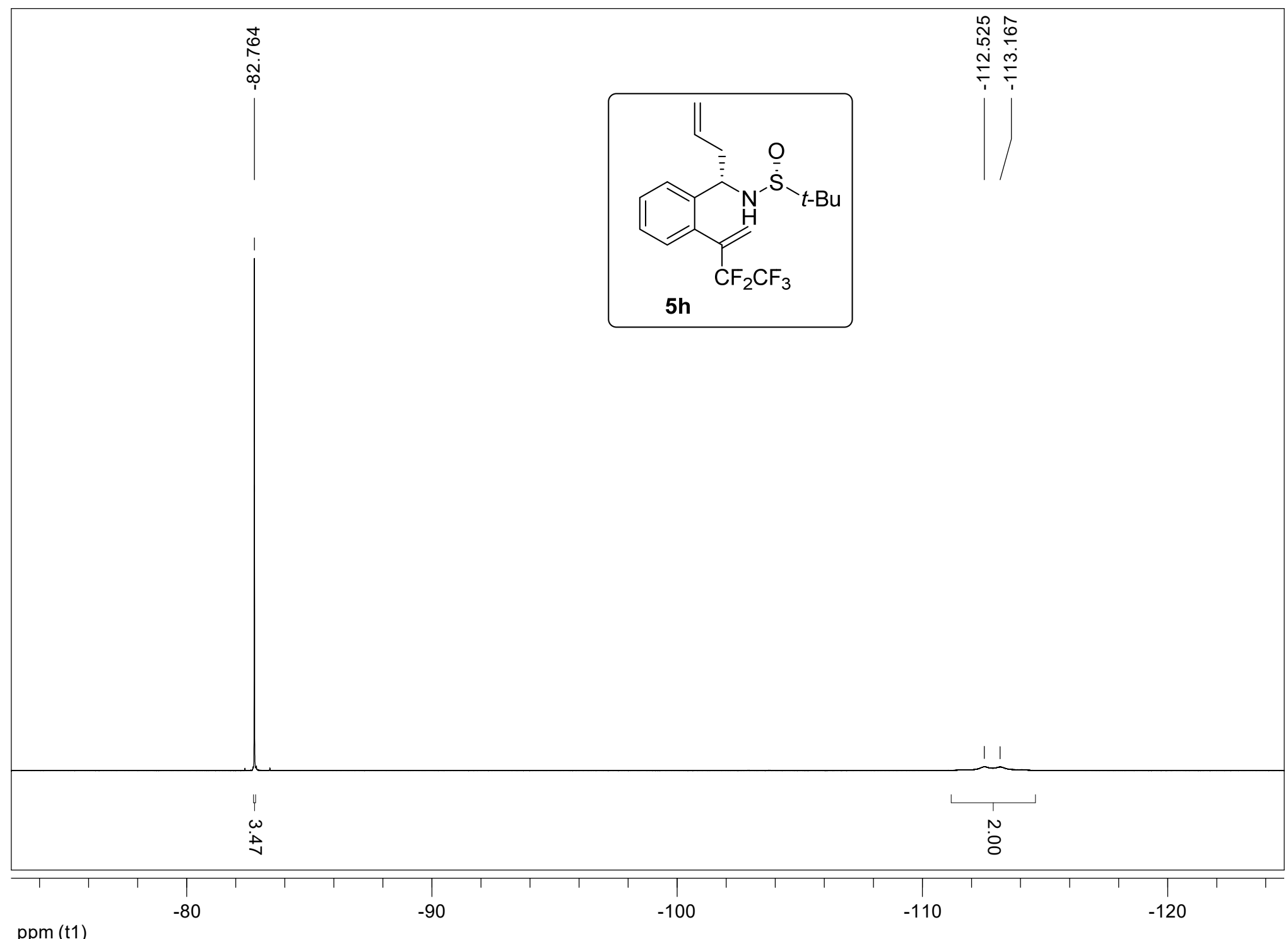




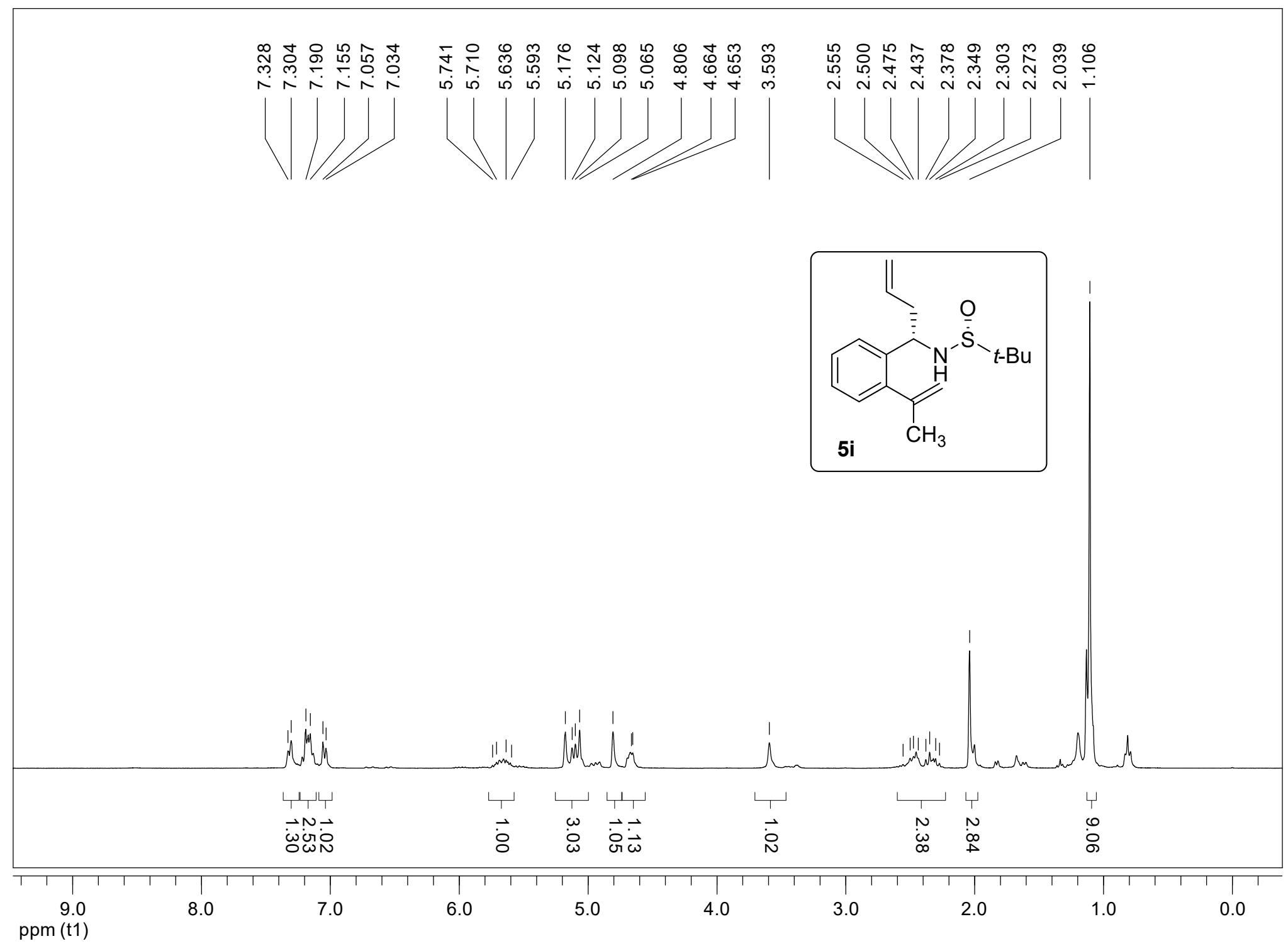




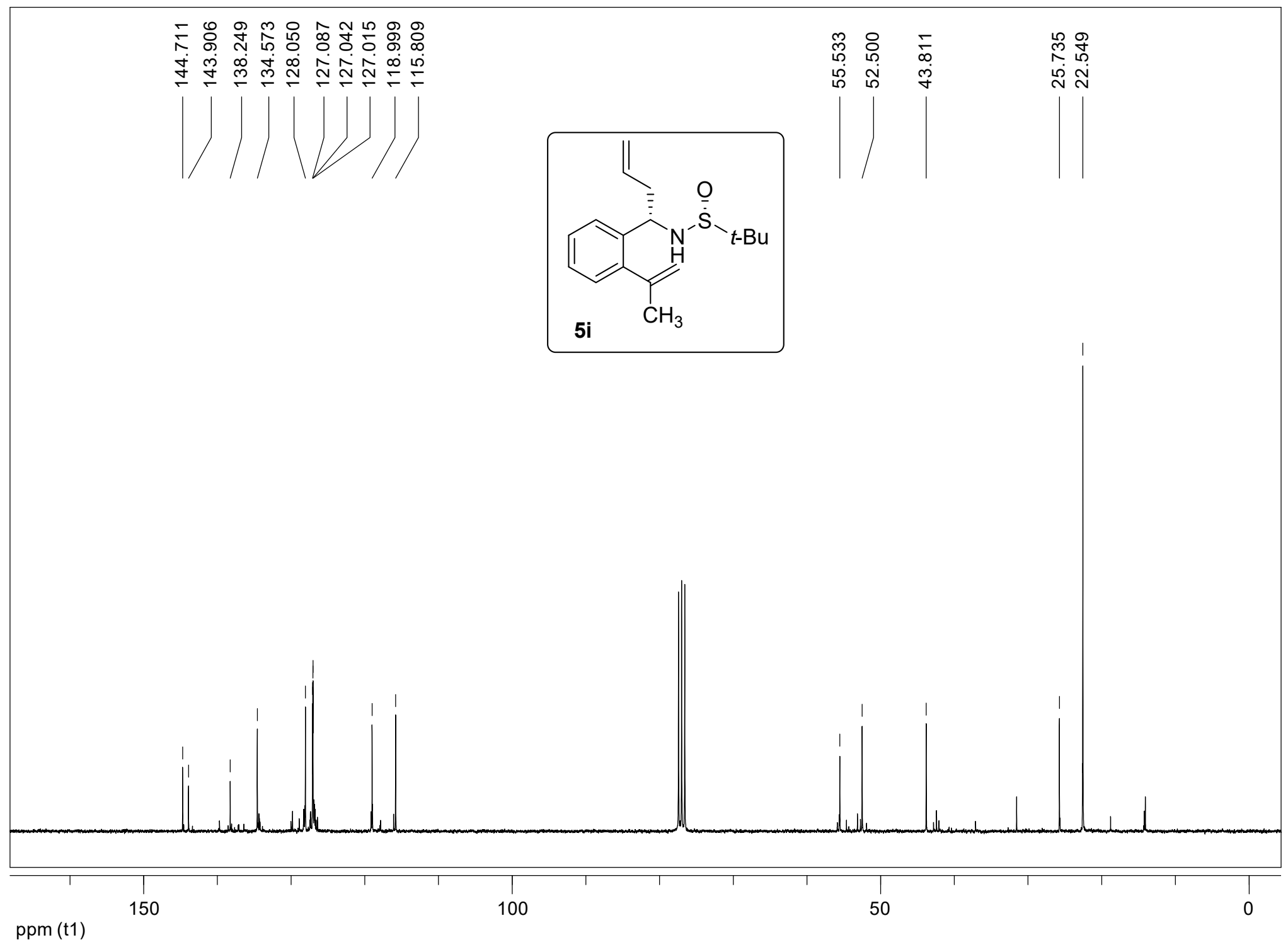




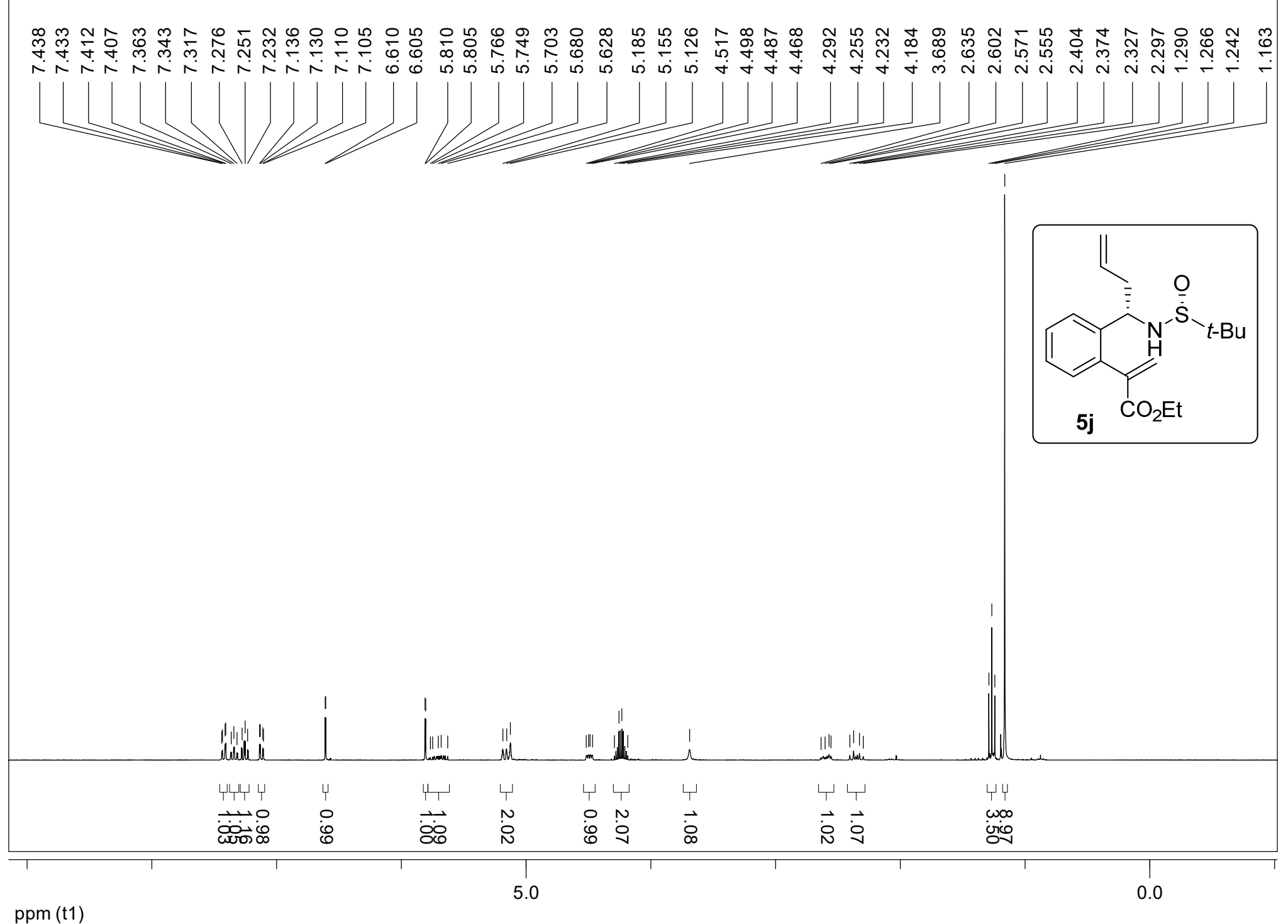




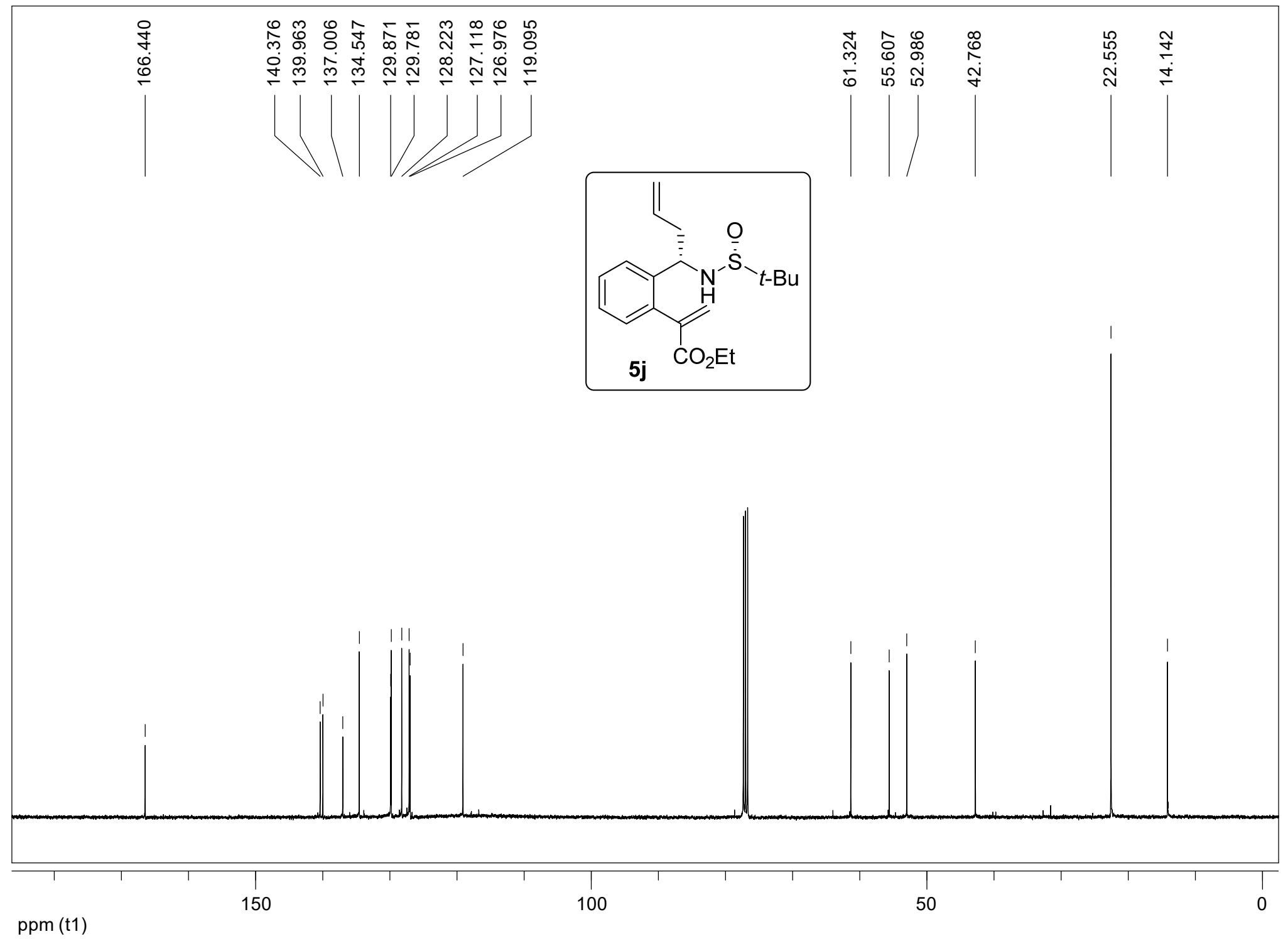




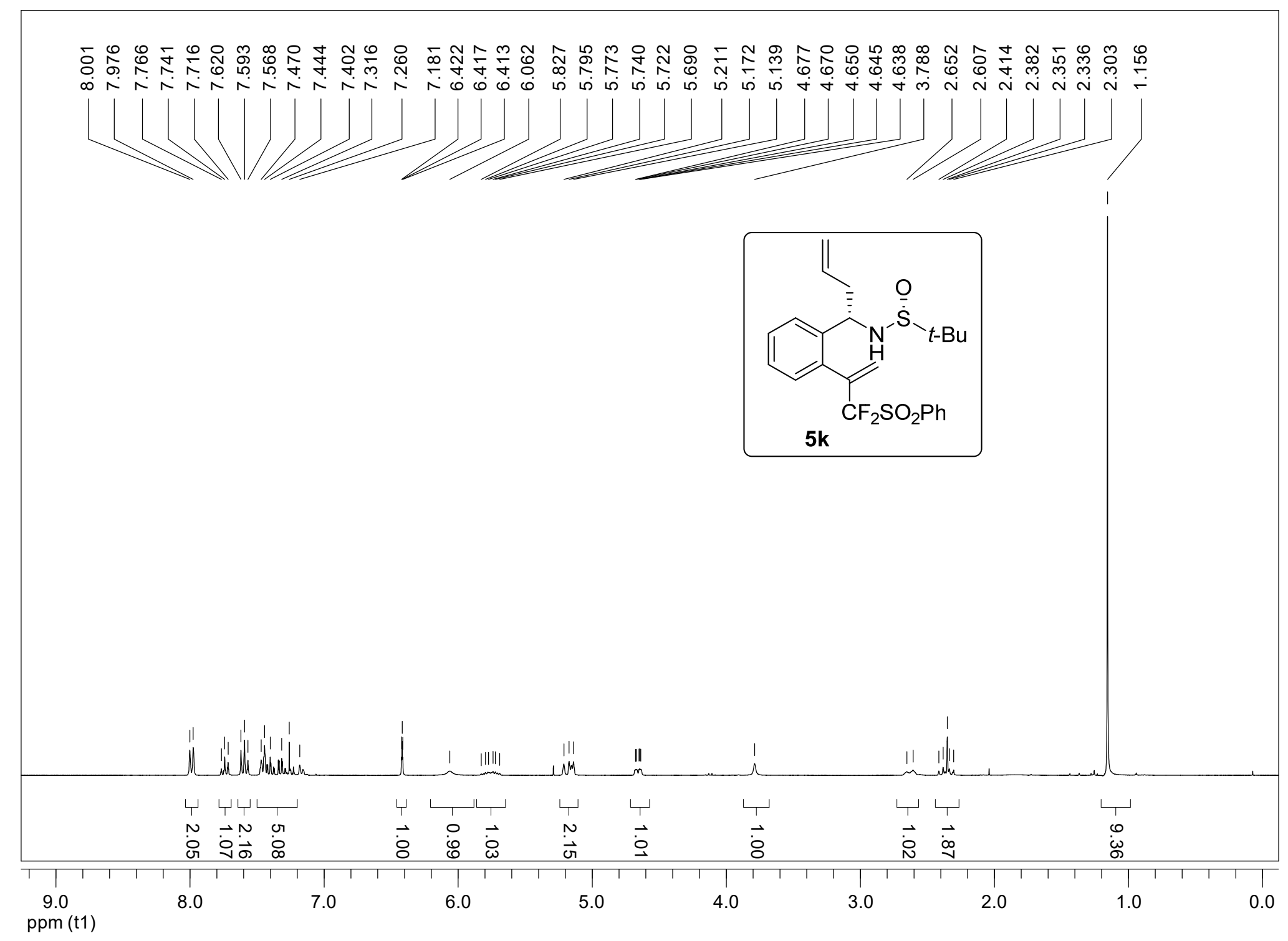




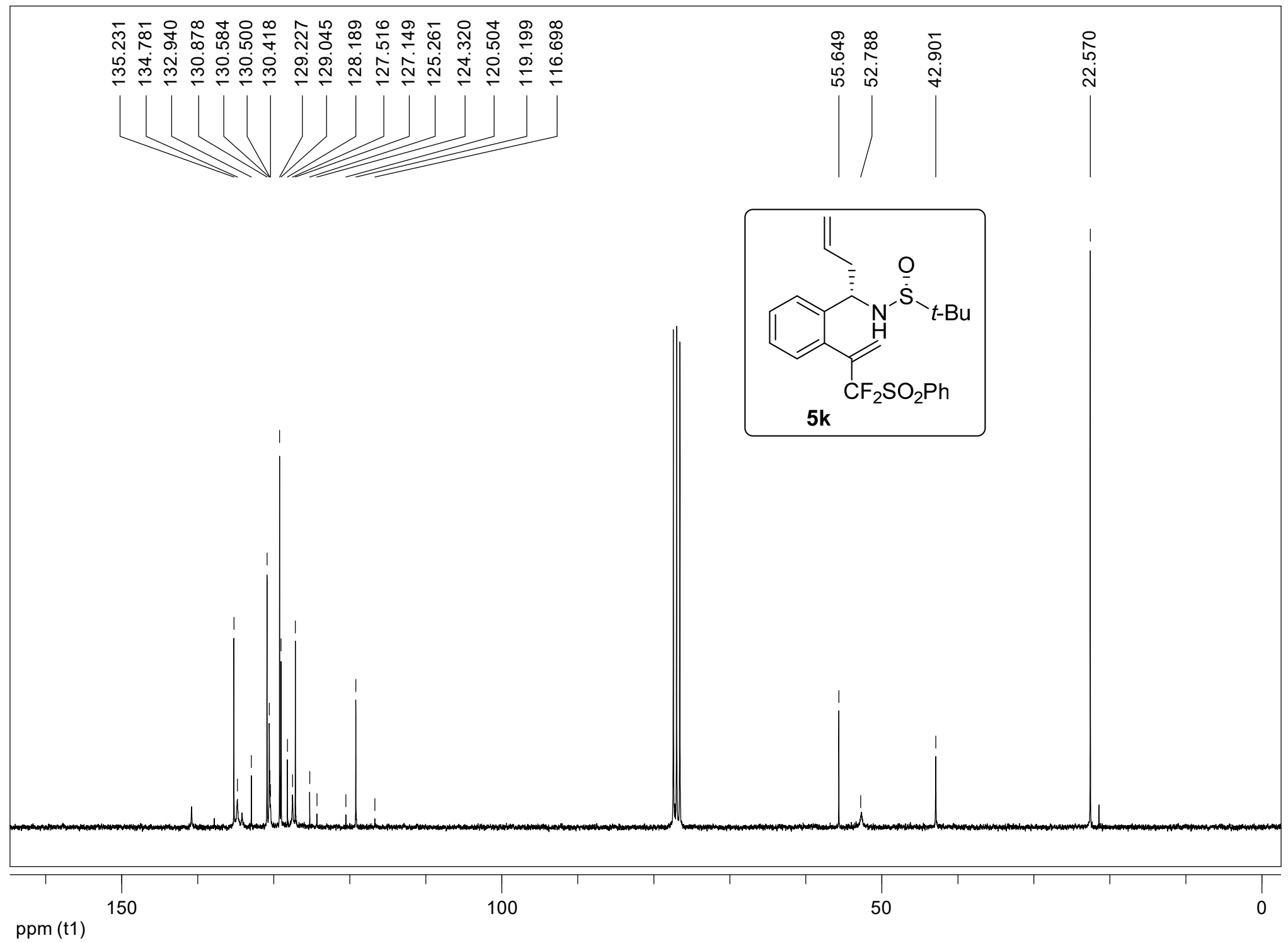




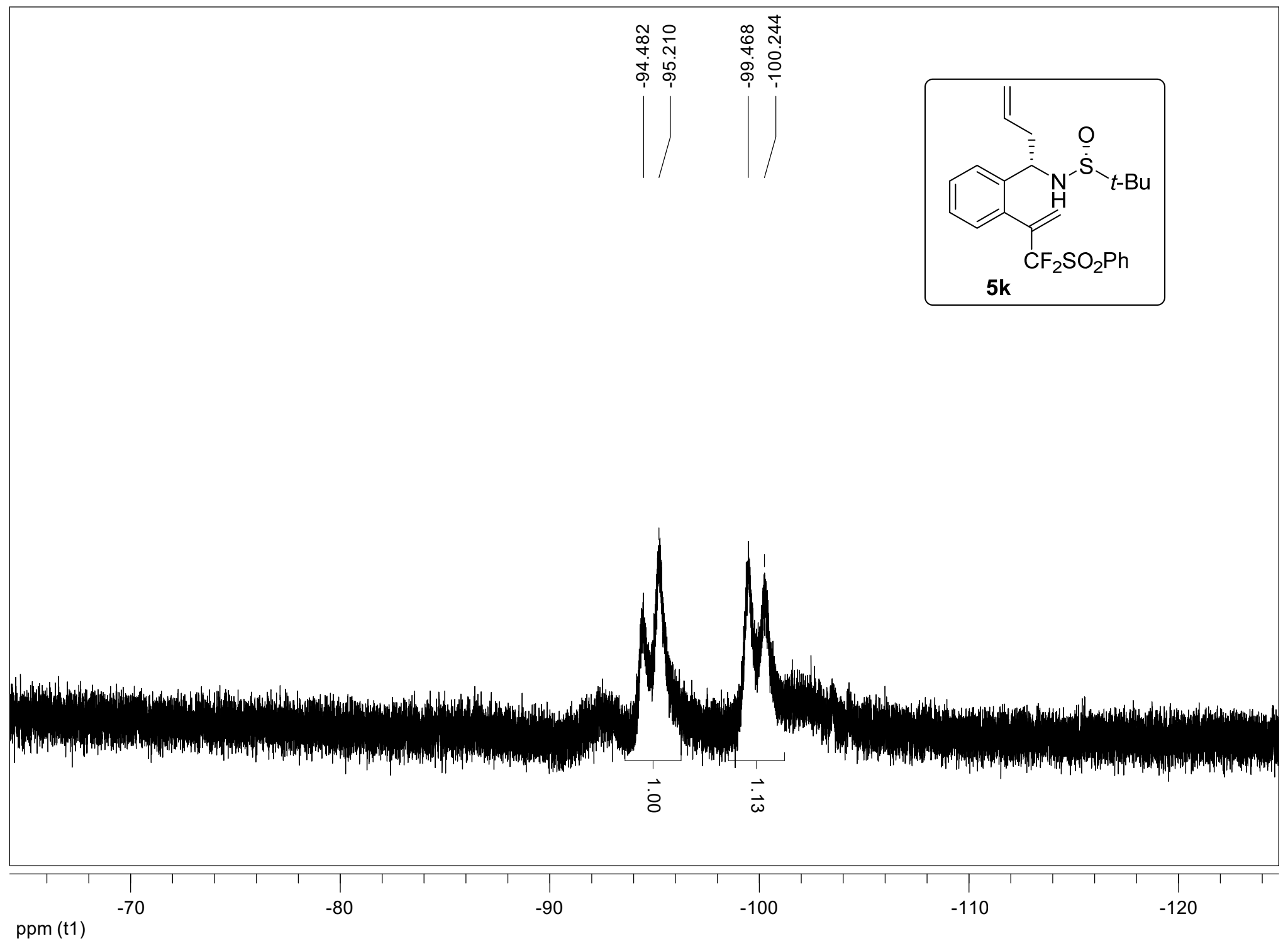




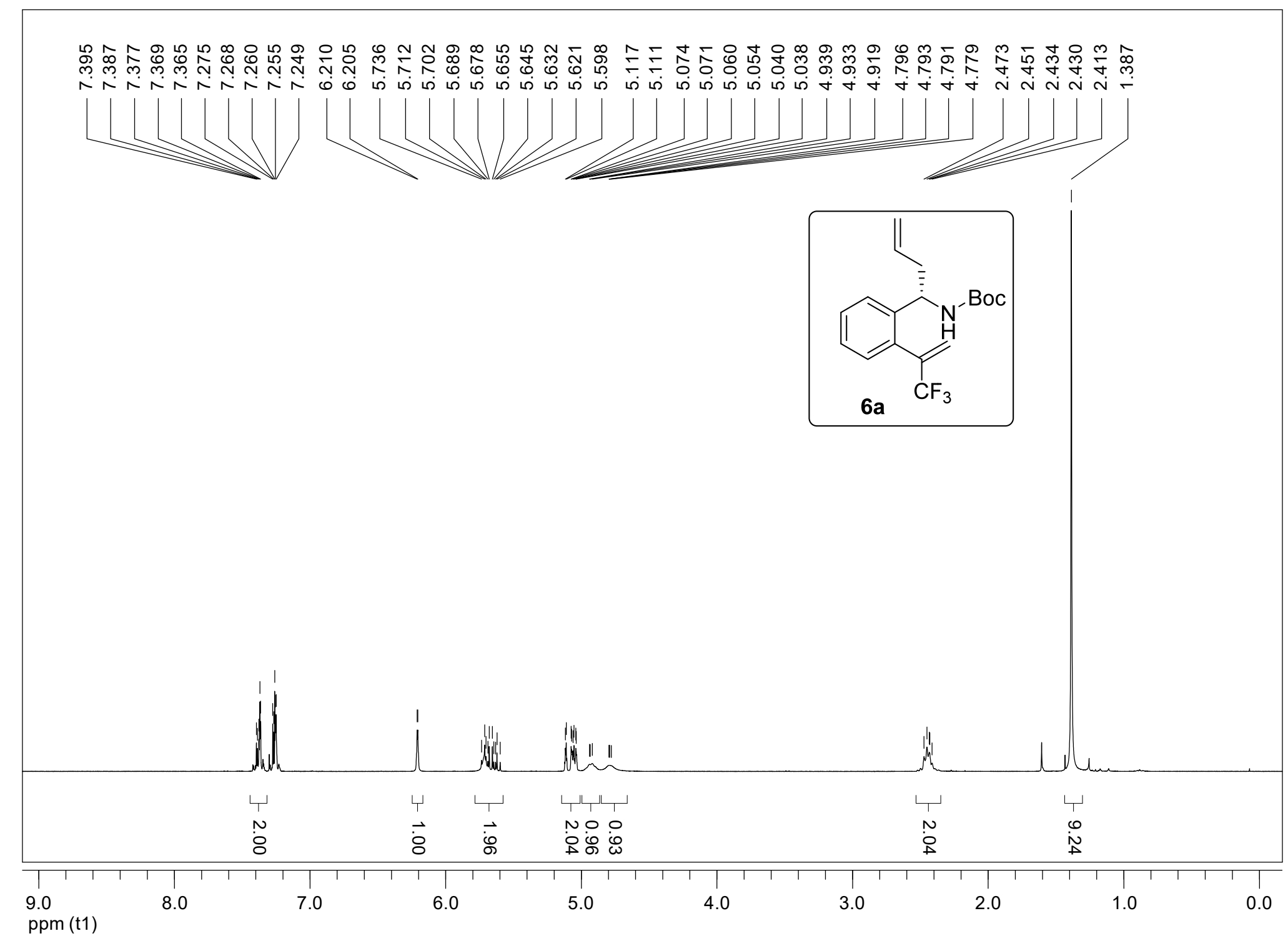




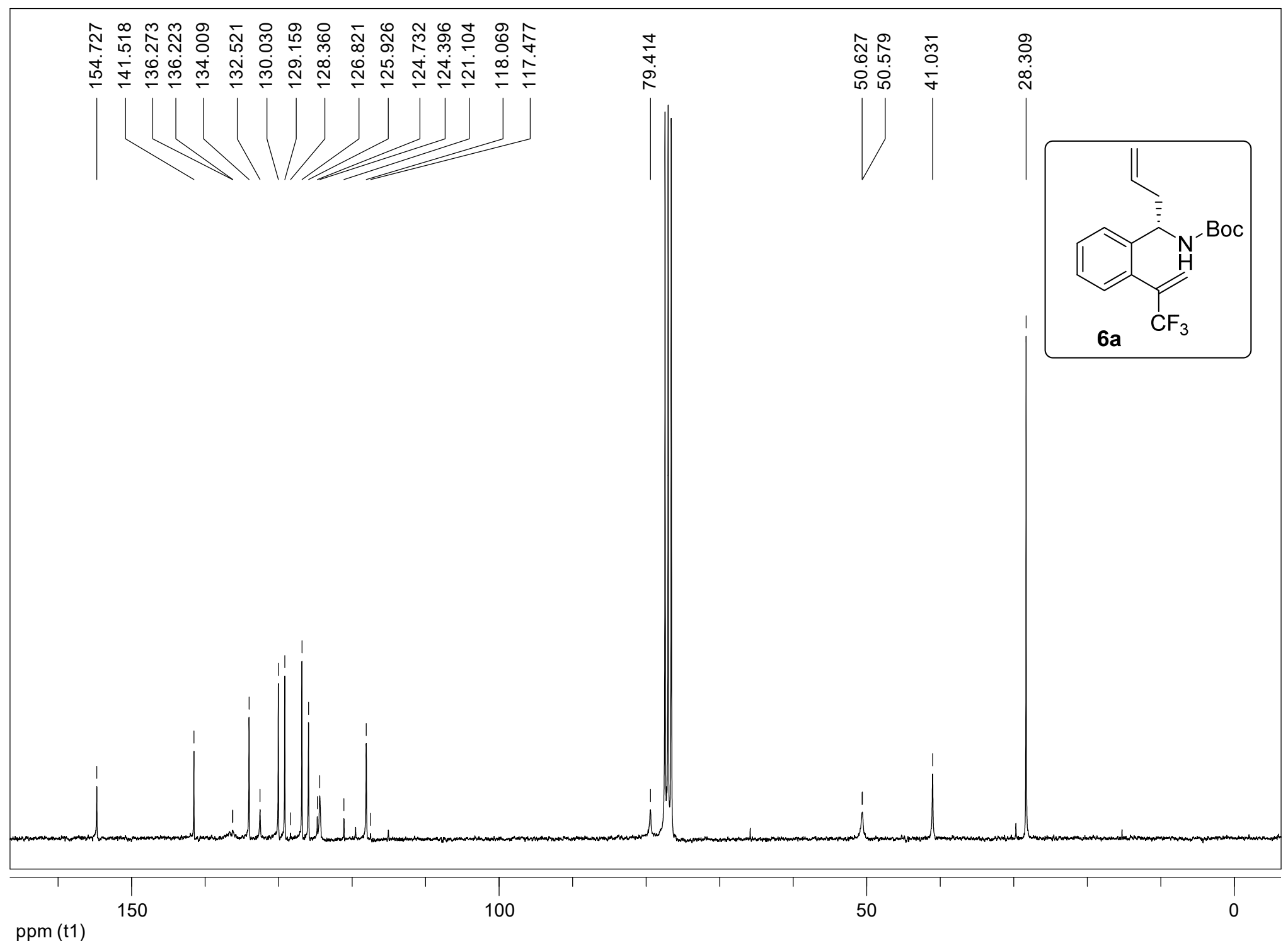




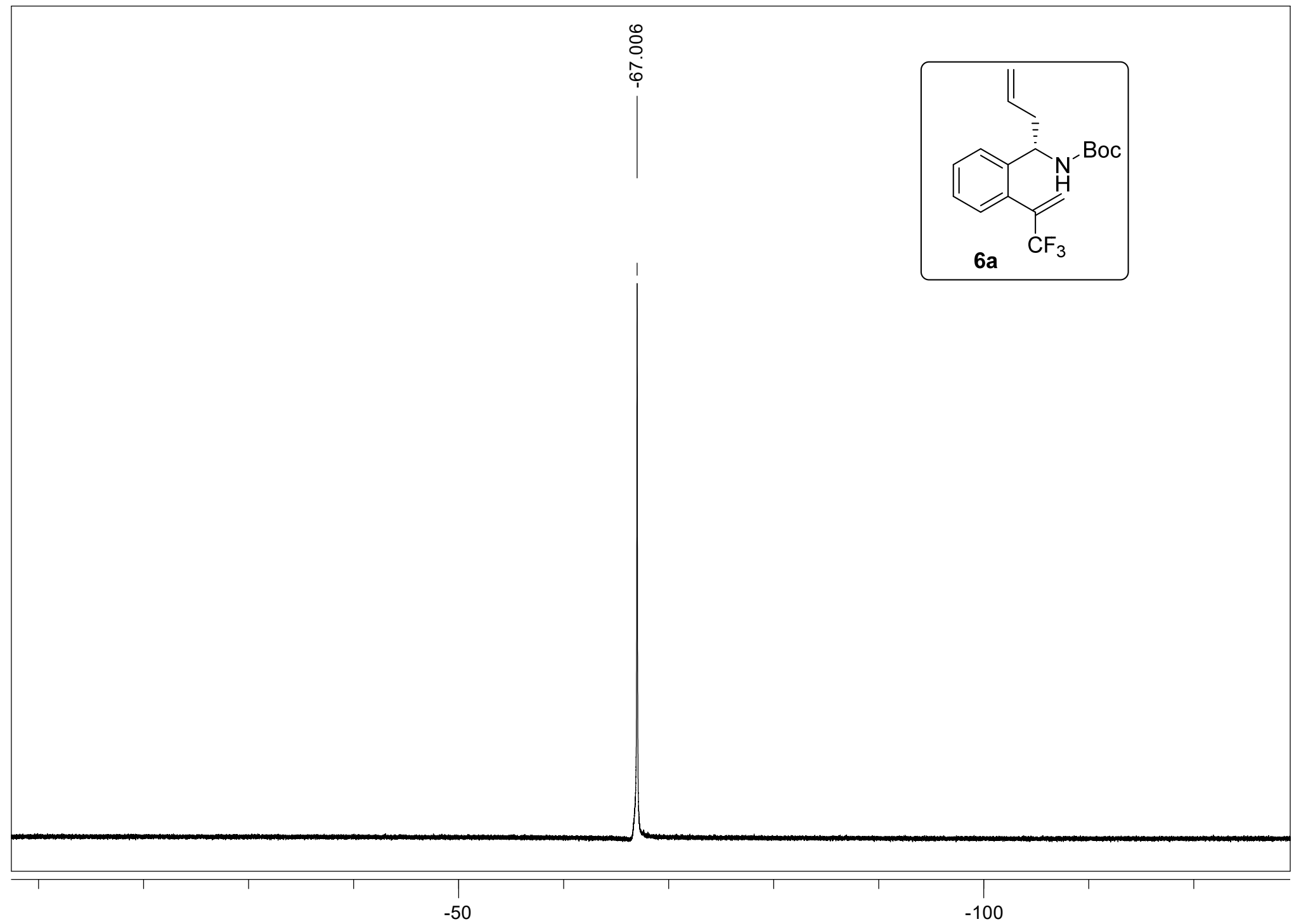

ppm (t1) 


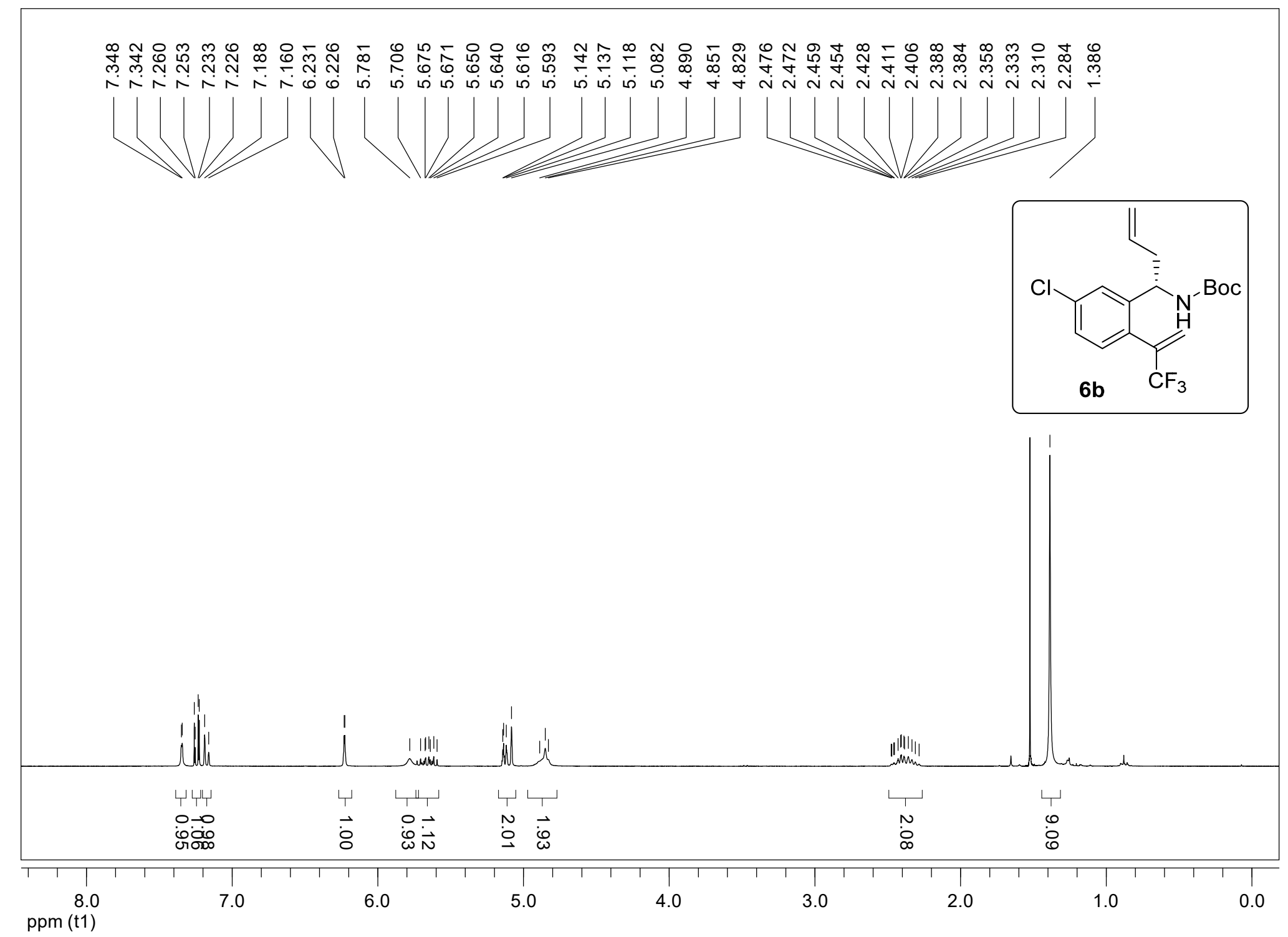




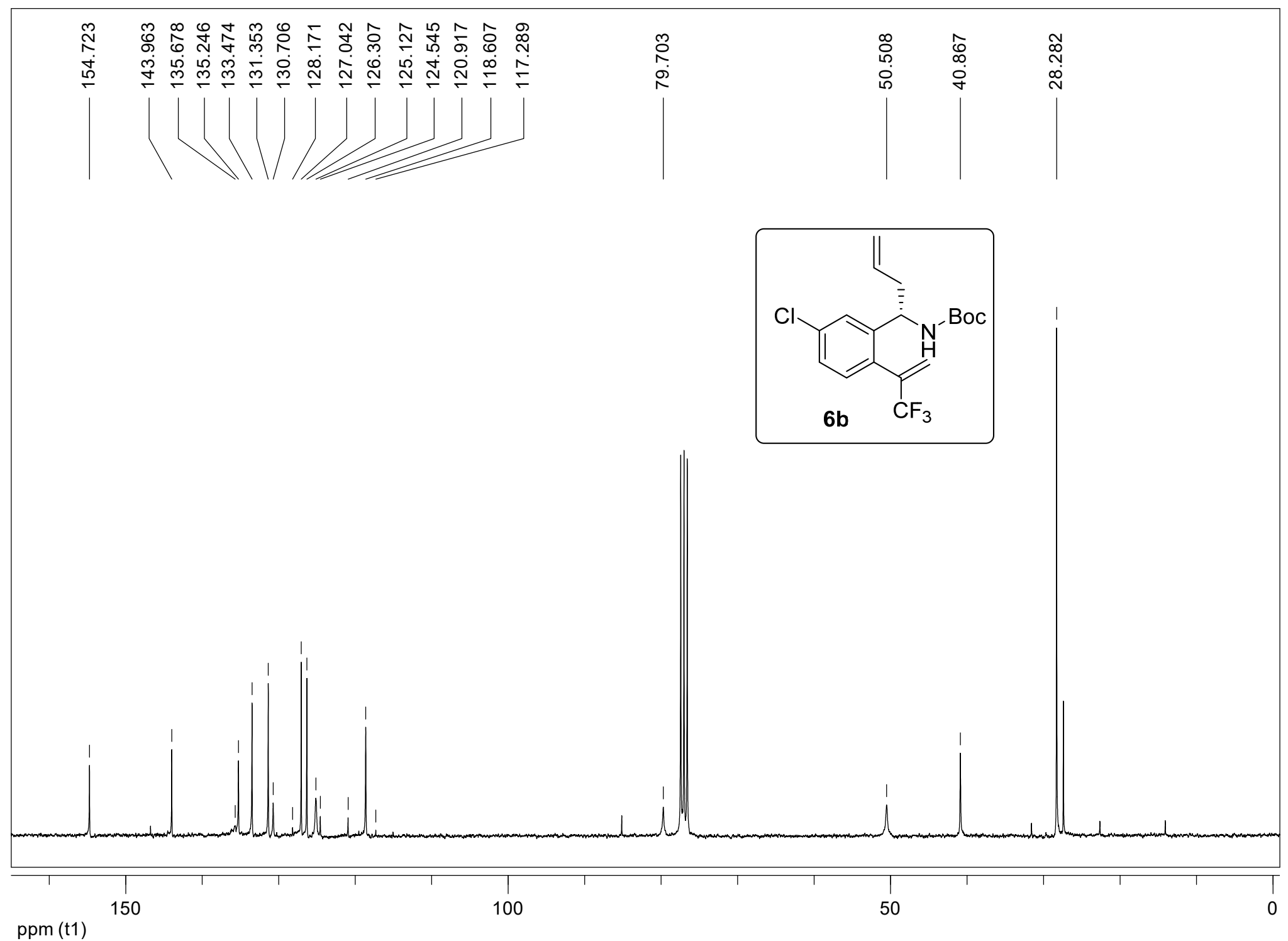




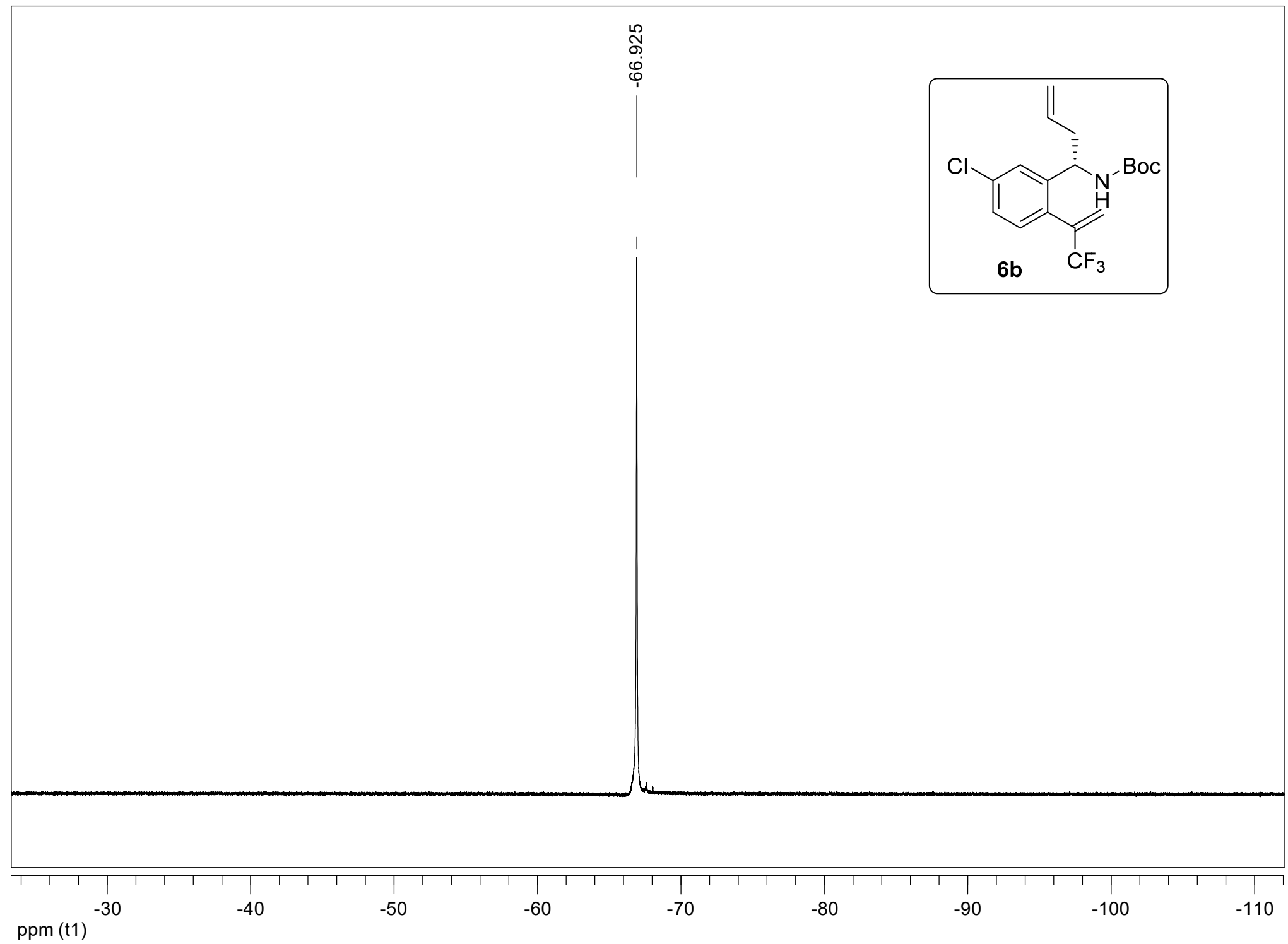




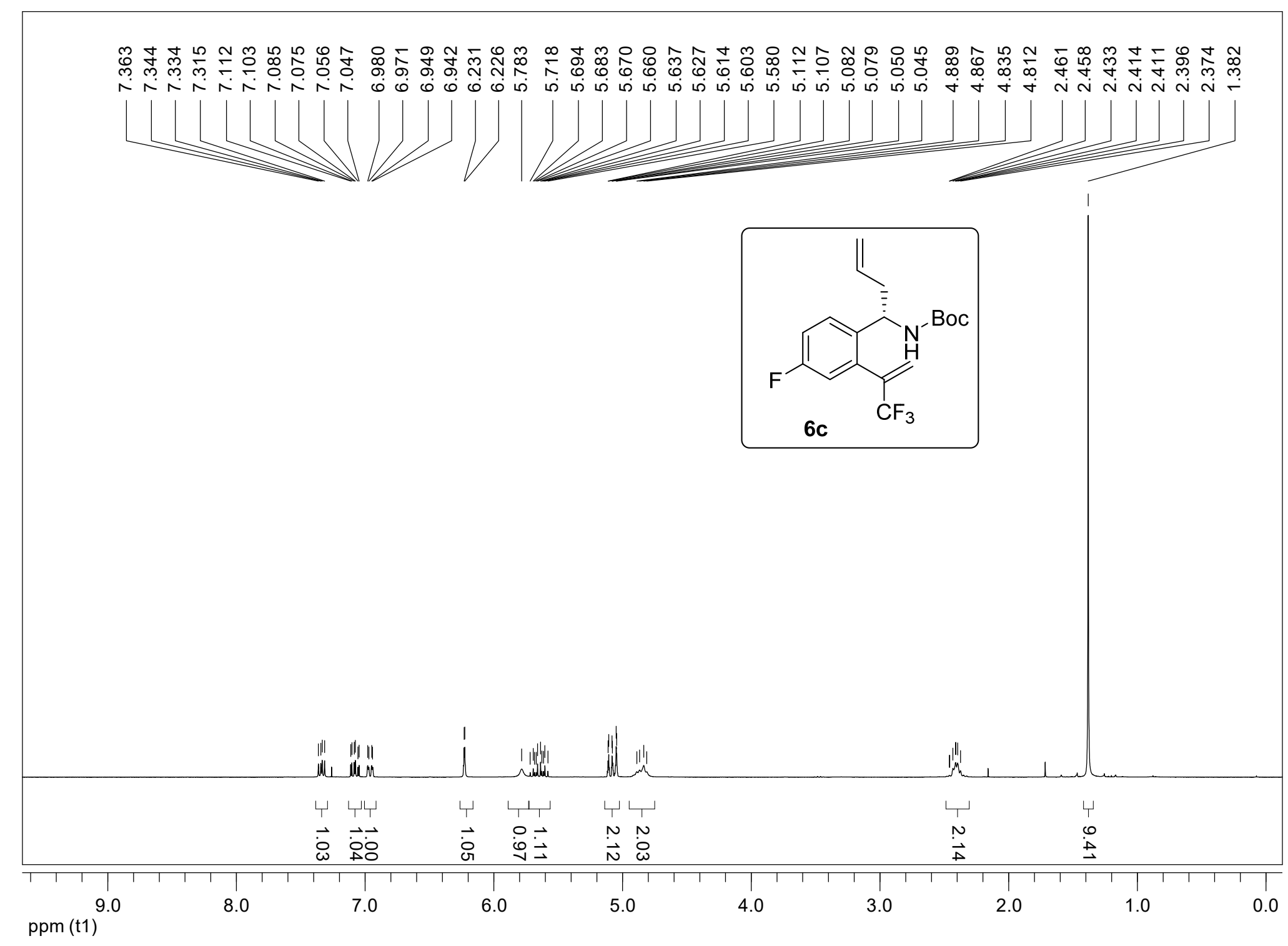




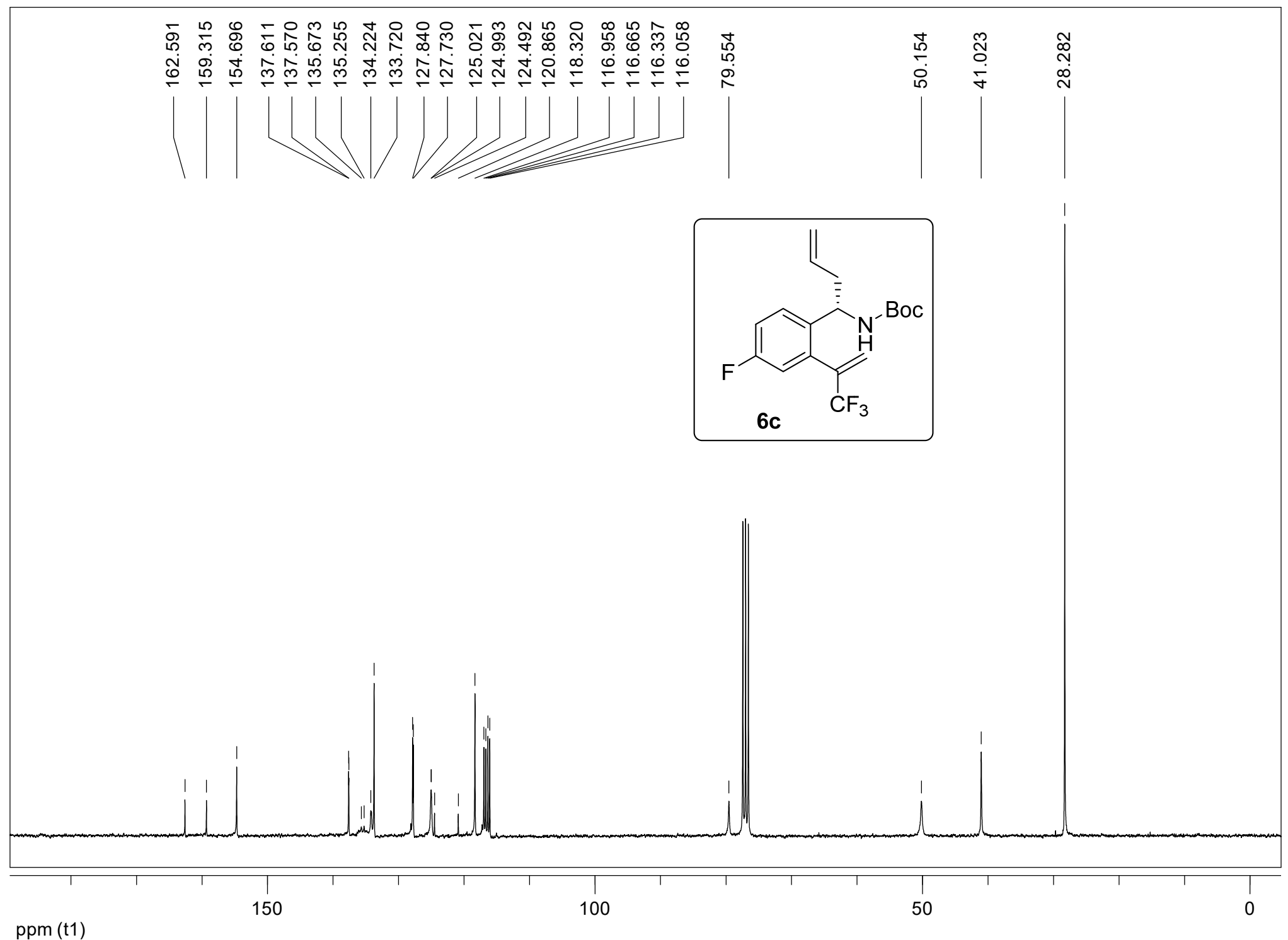




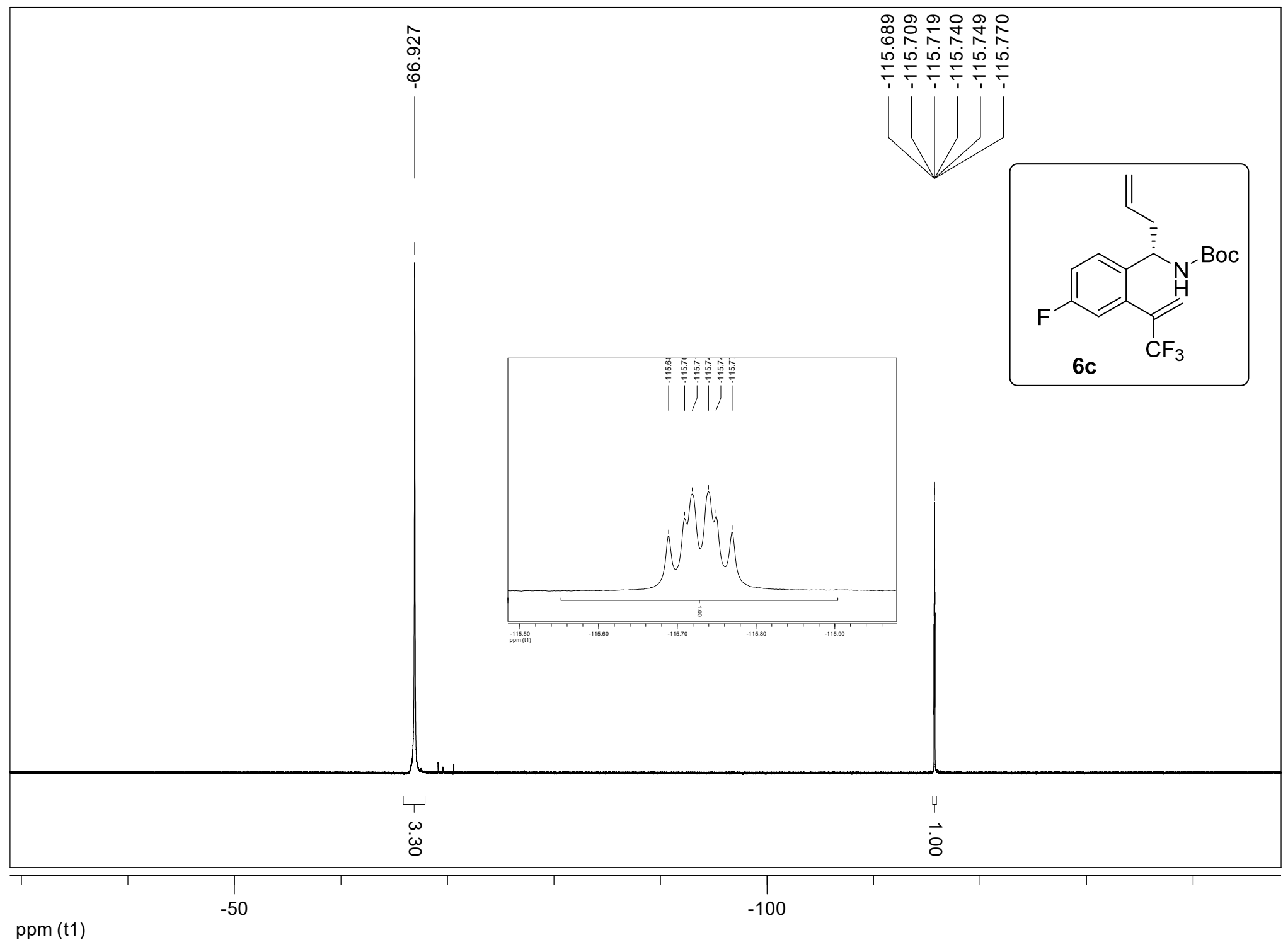




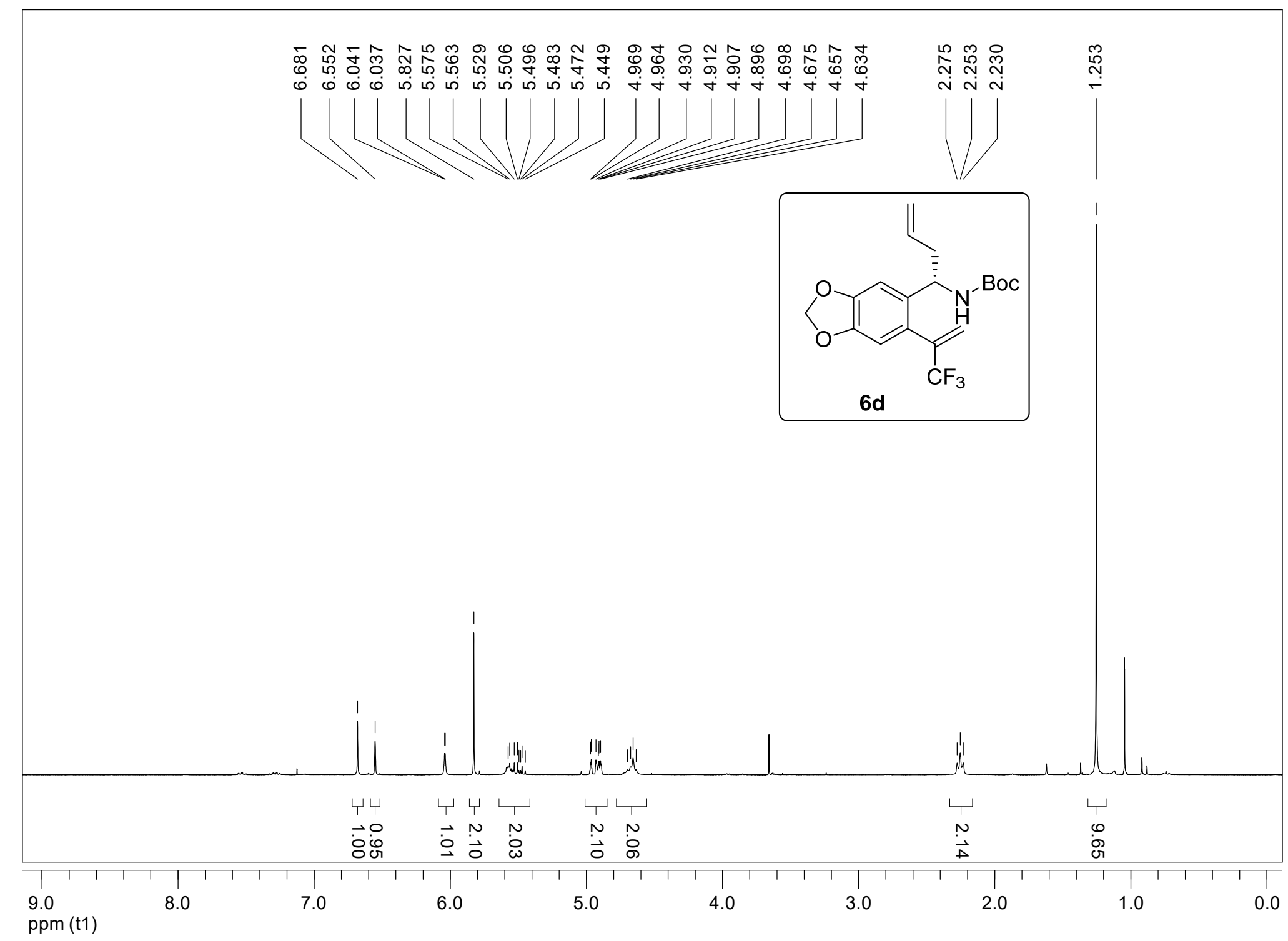




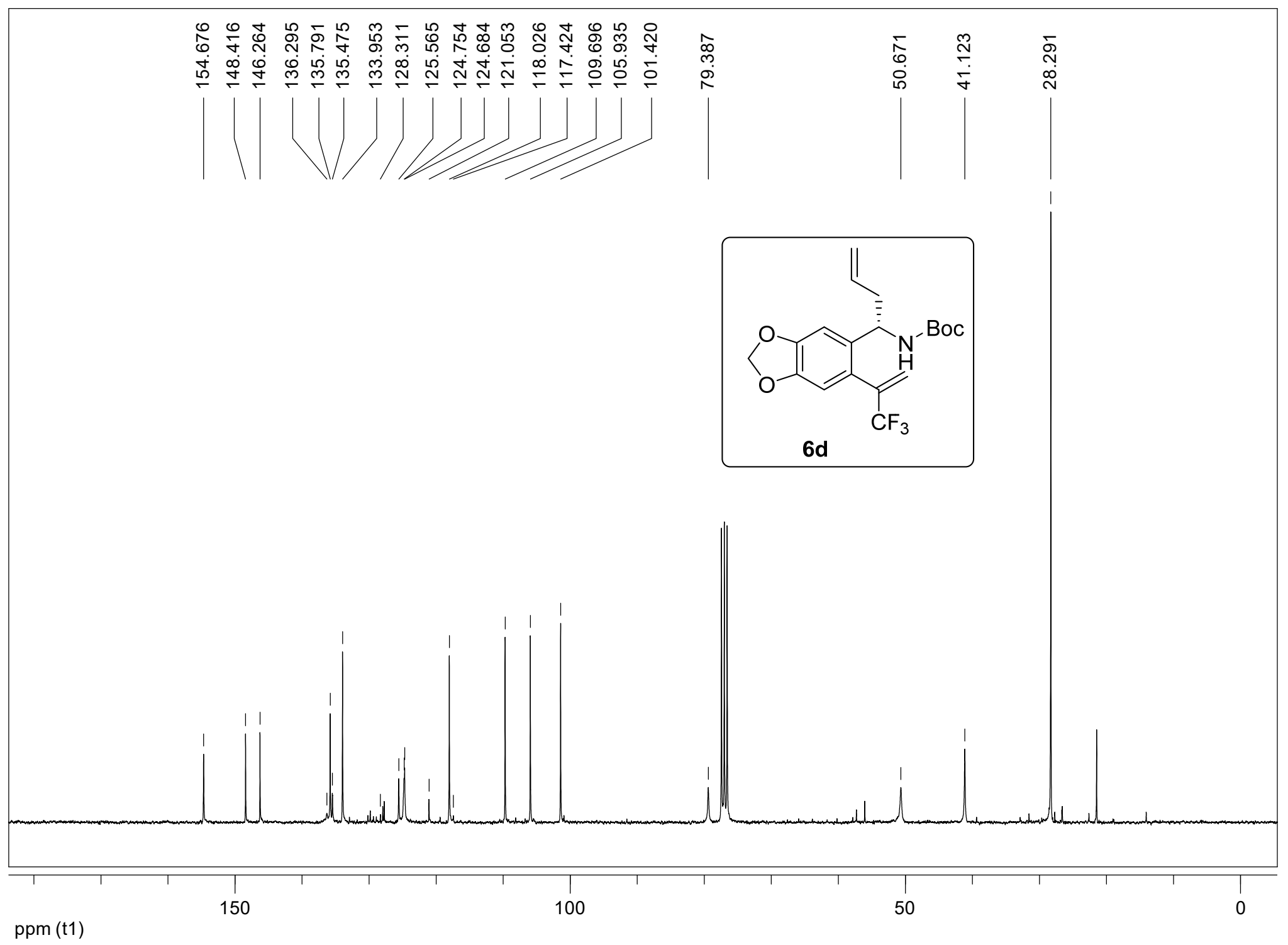




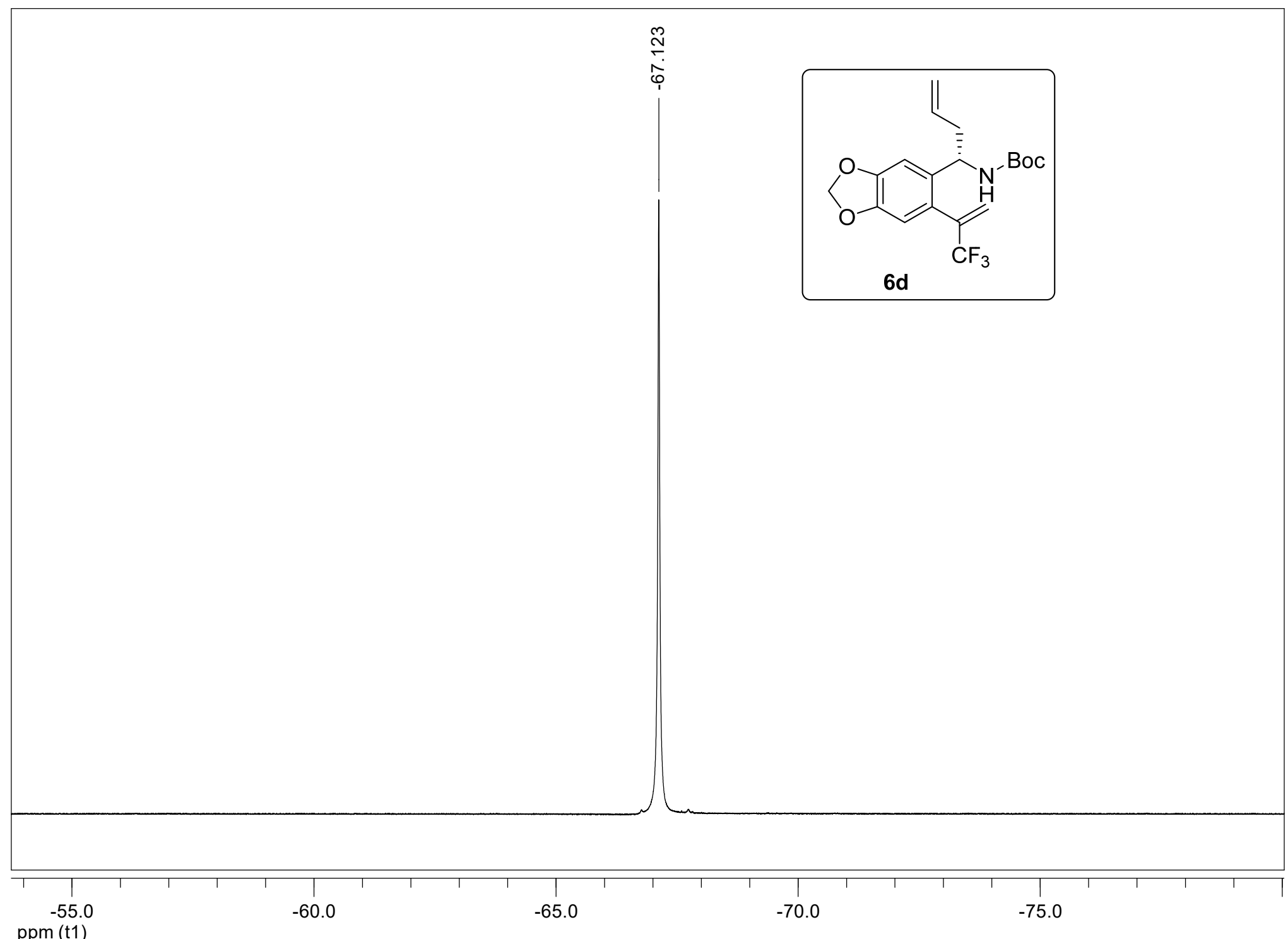




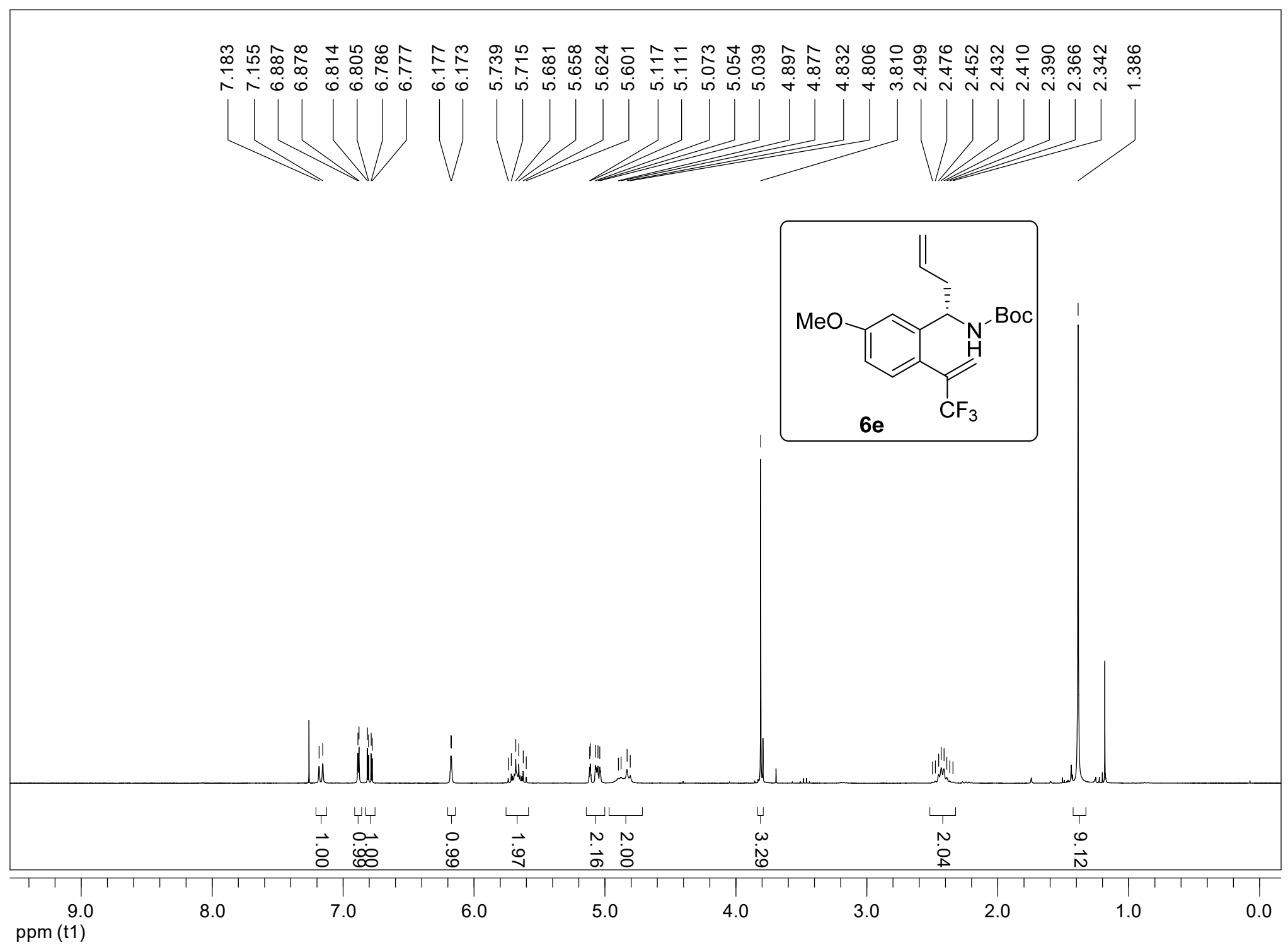




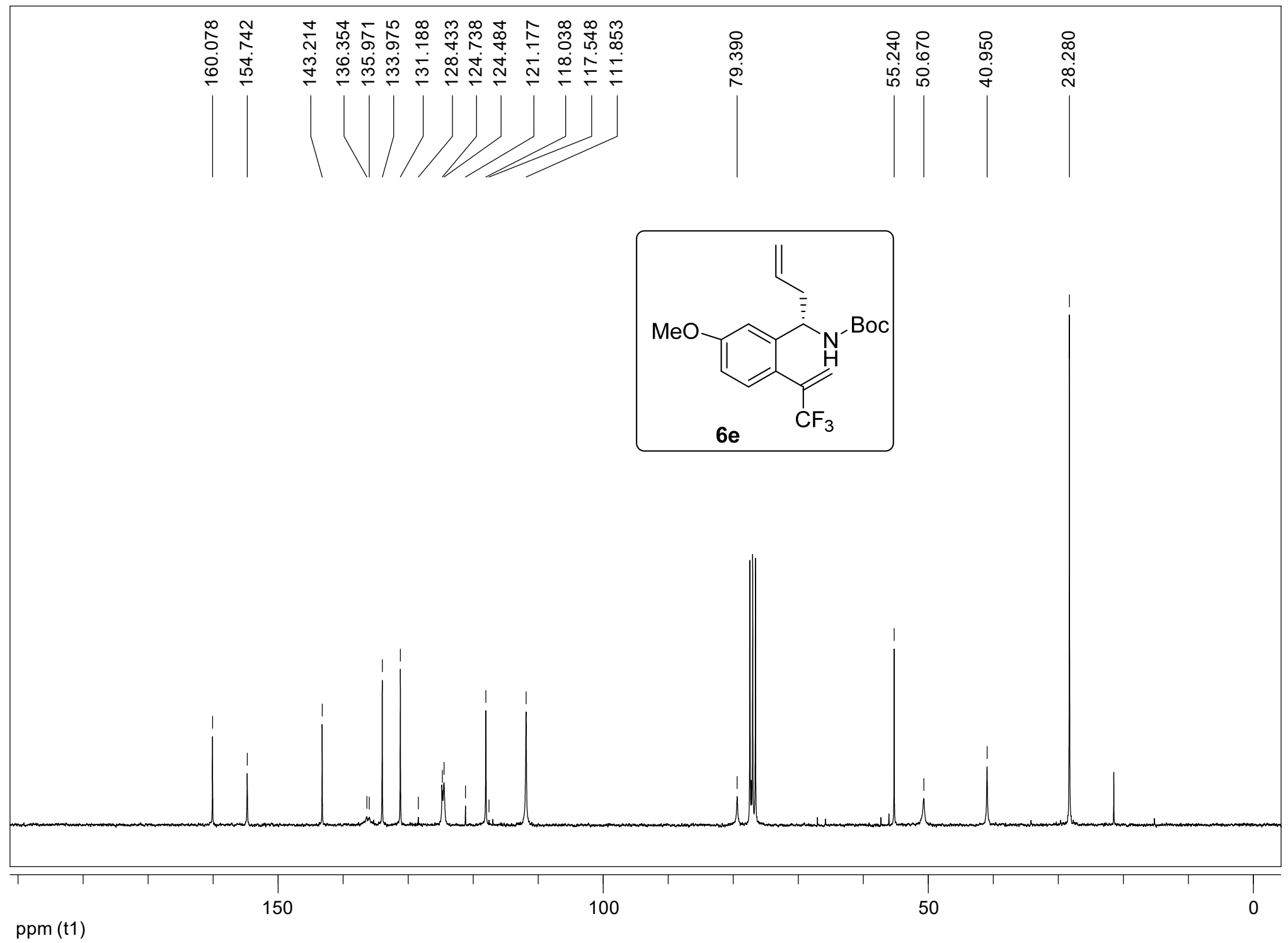




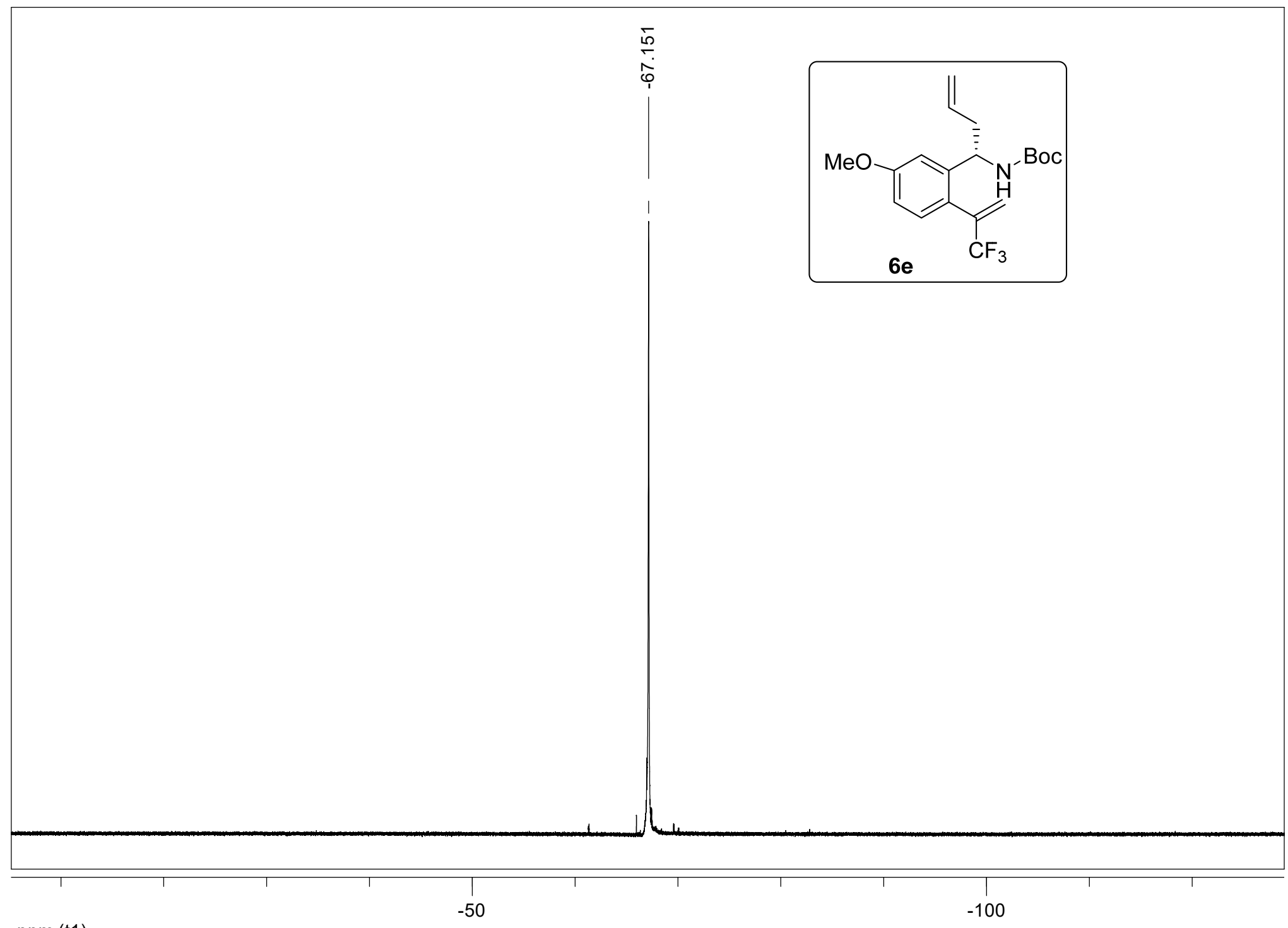

ppm (t1) 


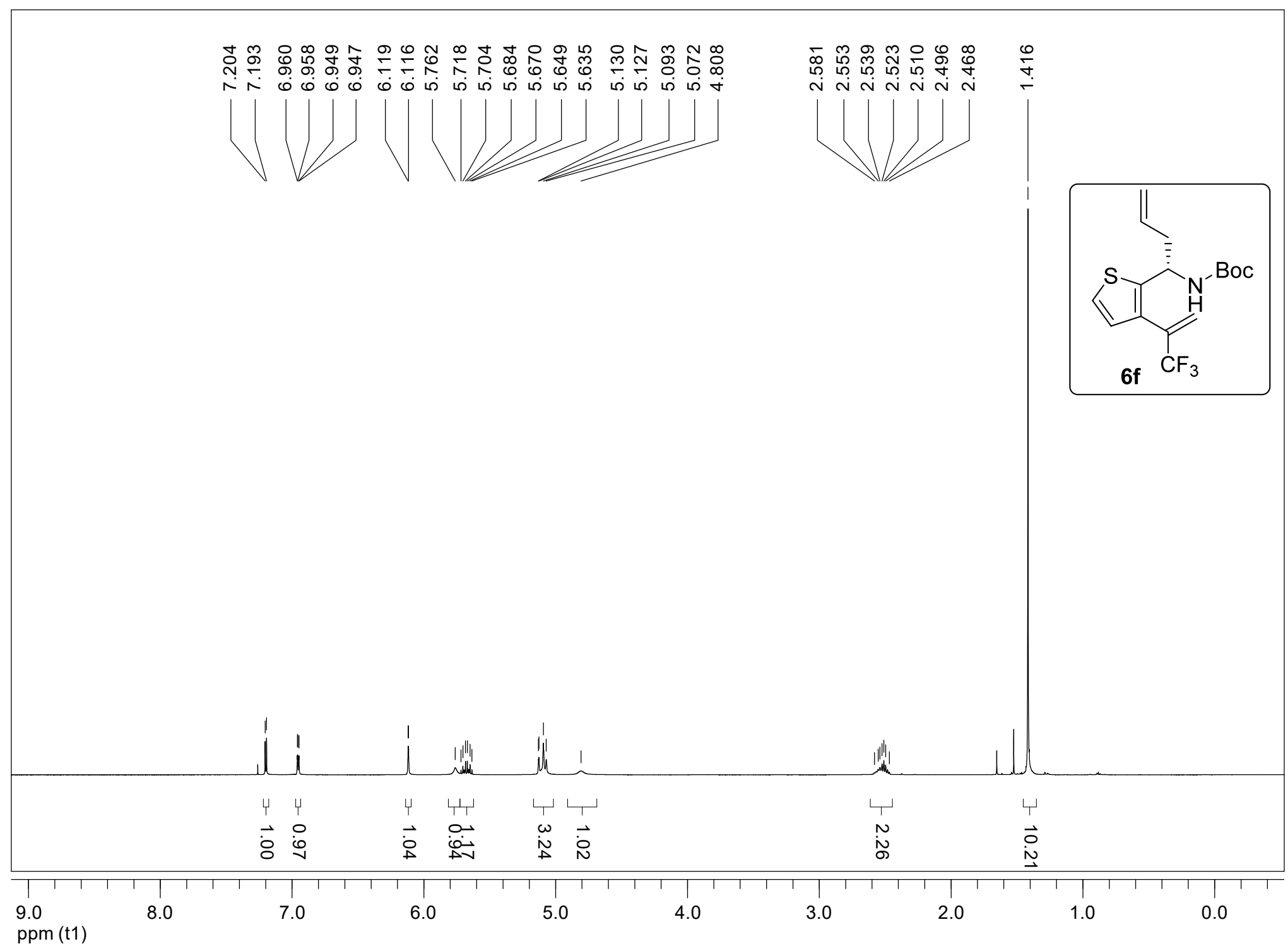




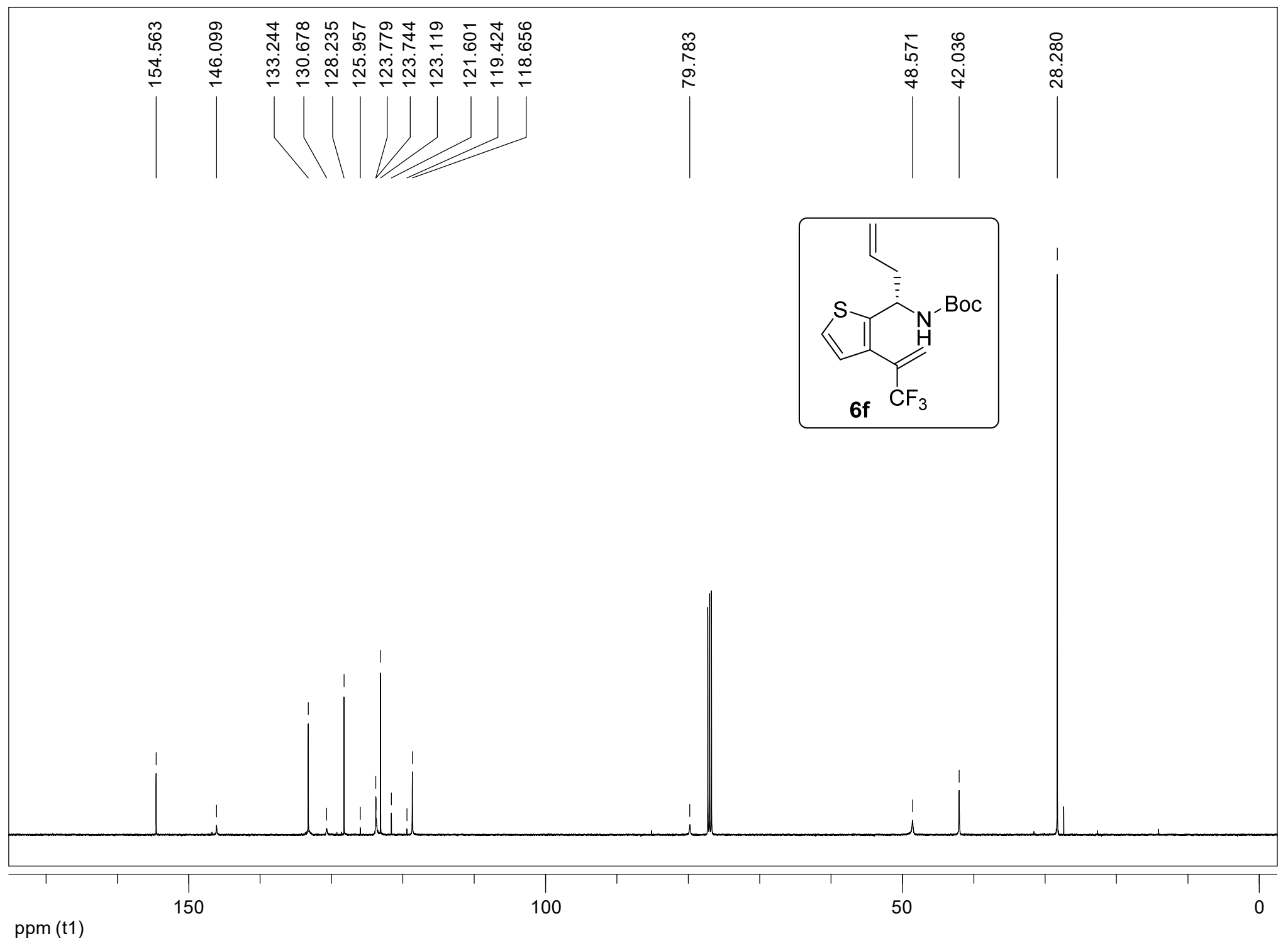




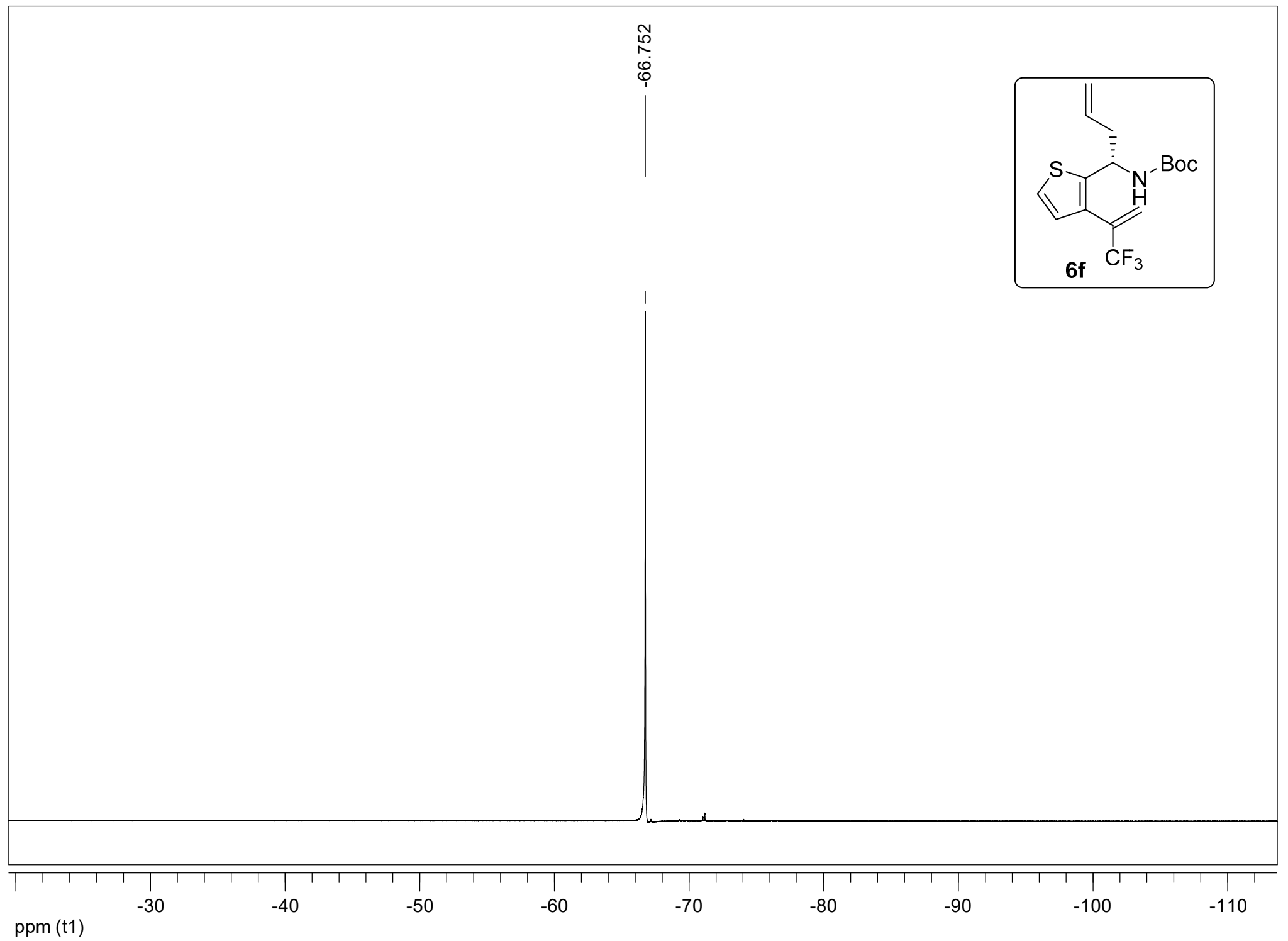




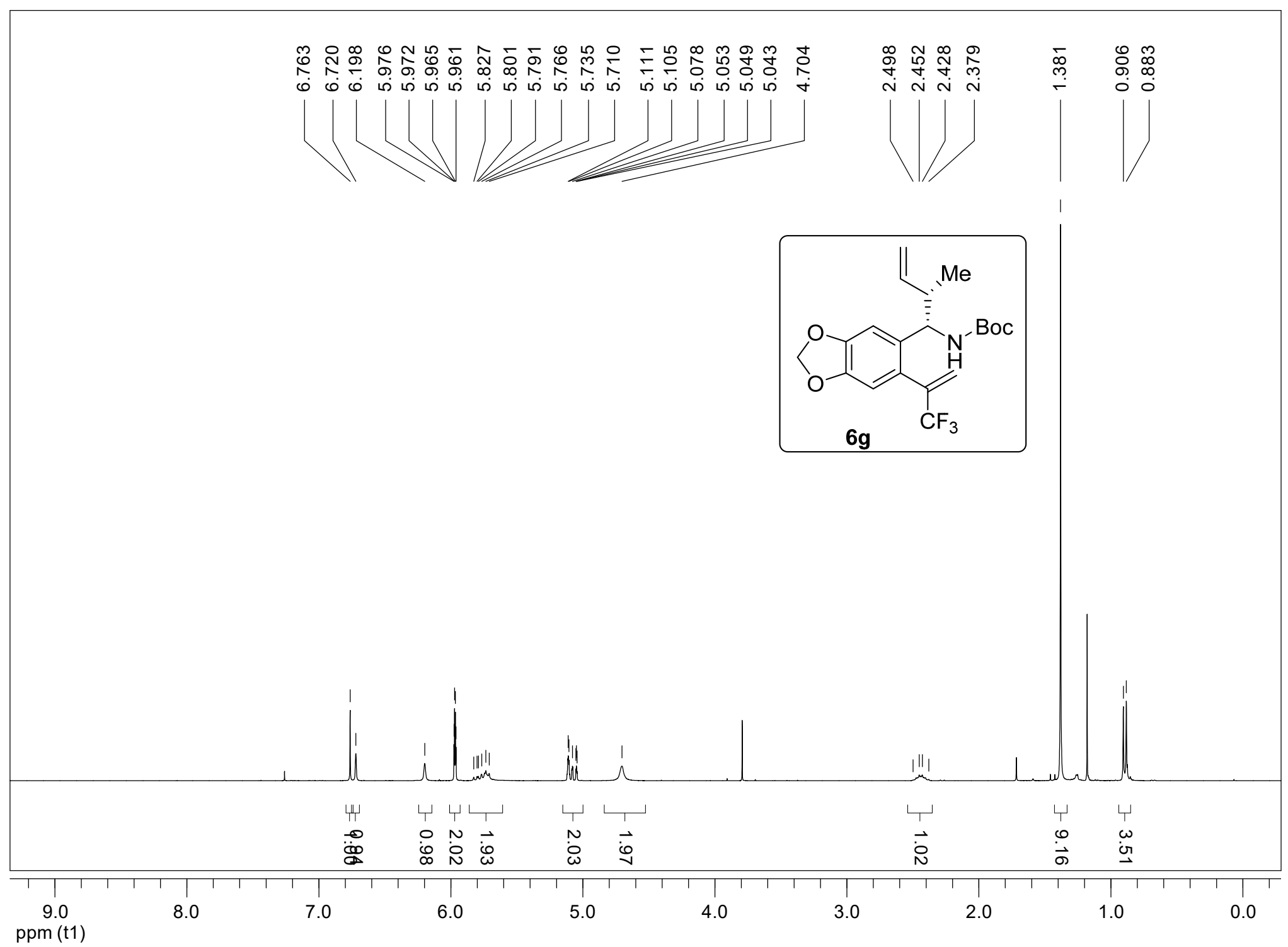




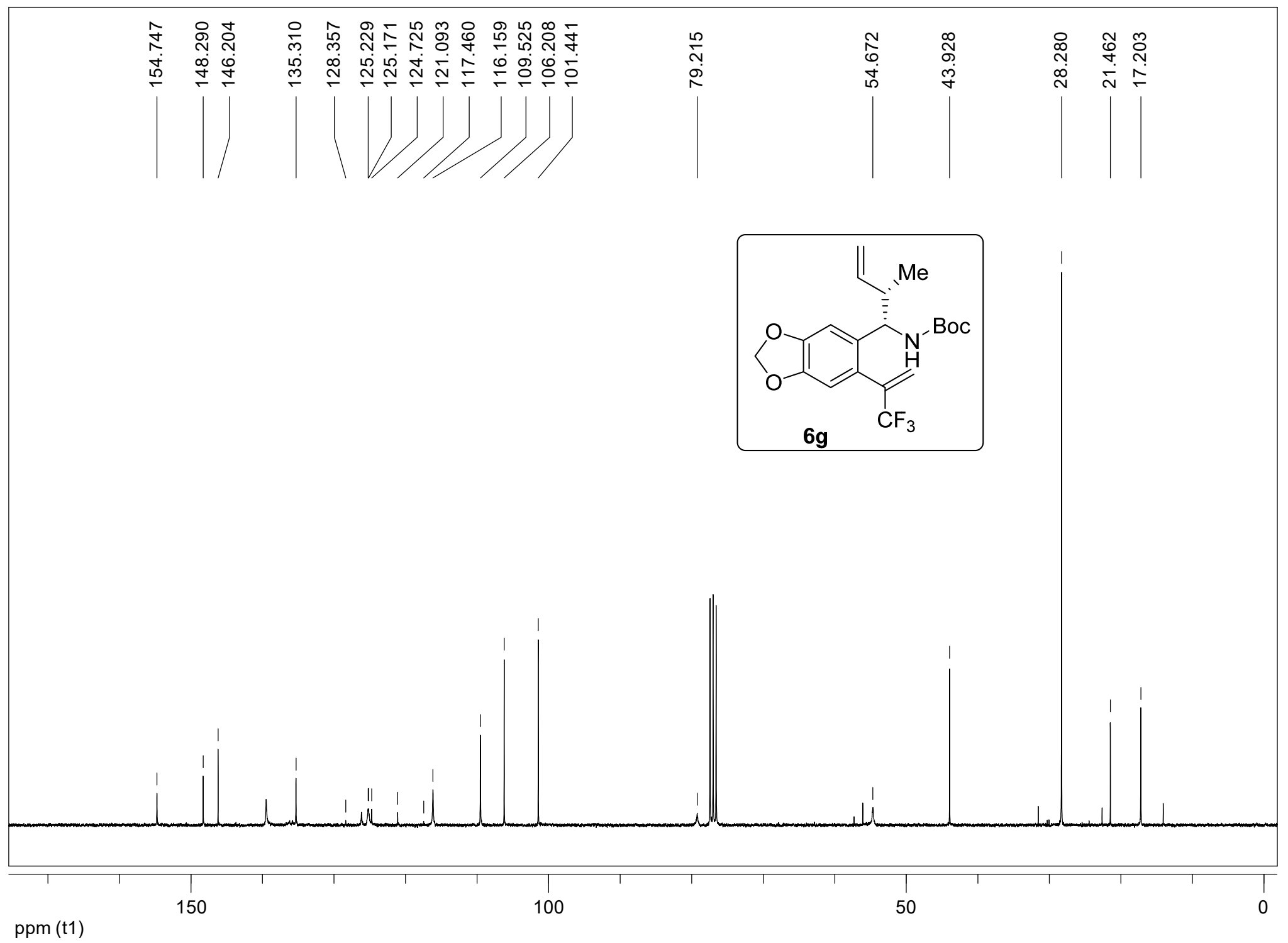




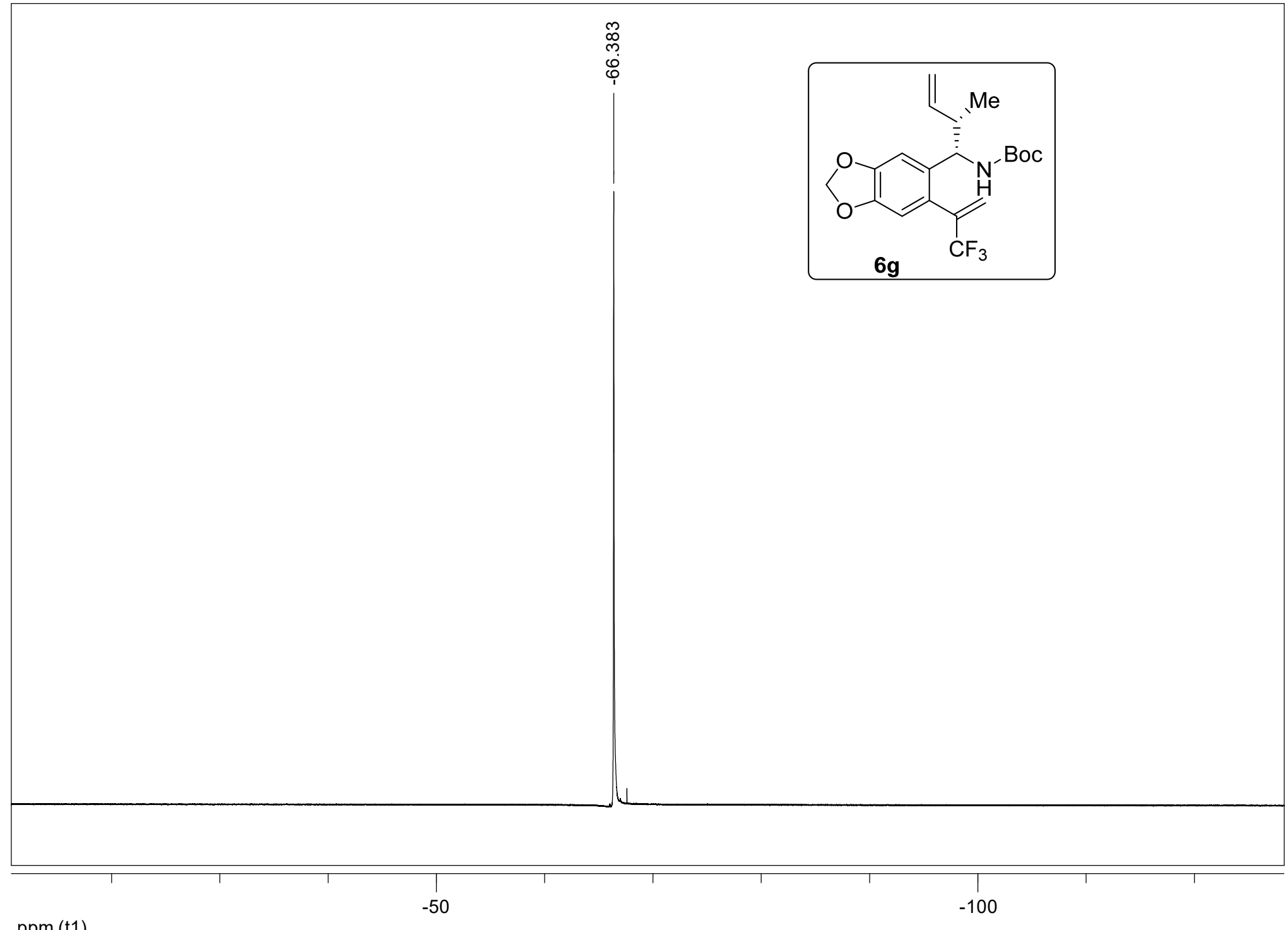

ppm (t1) 


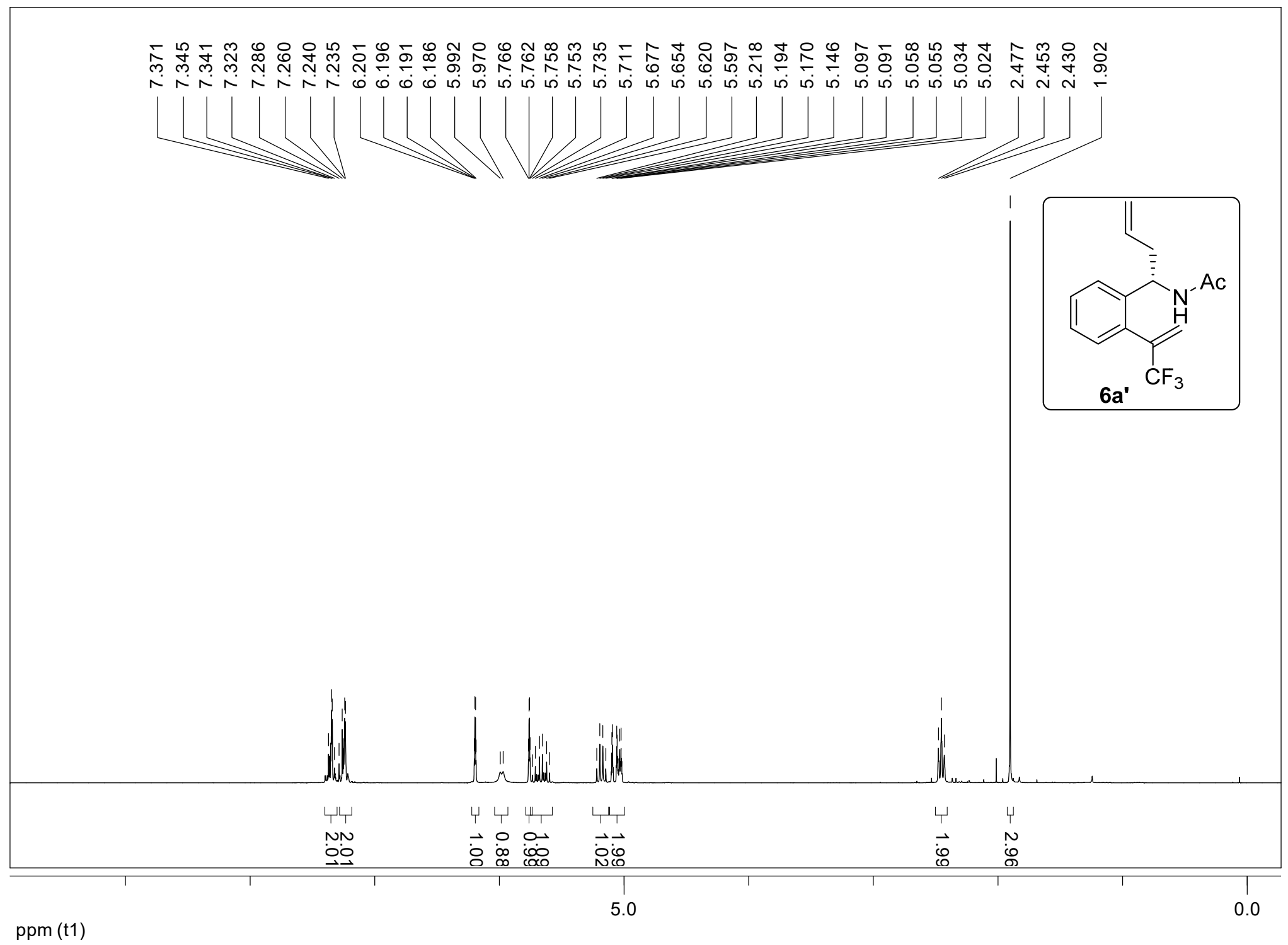




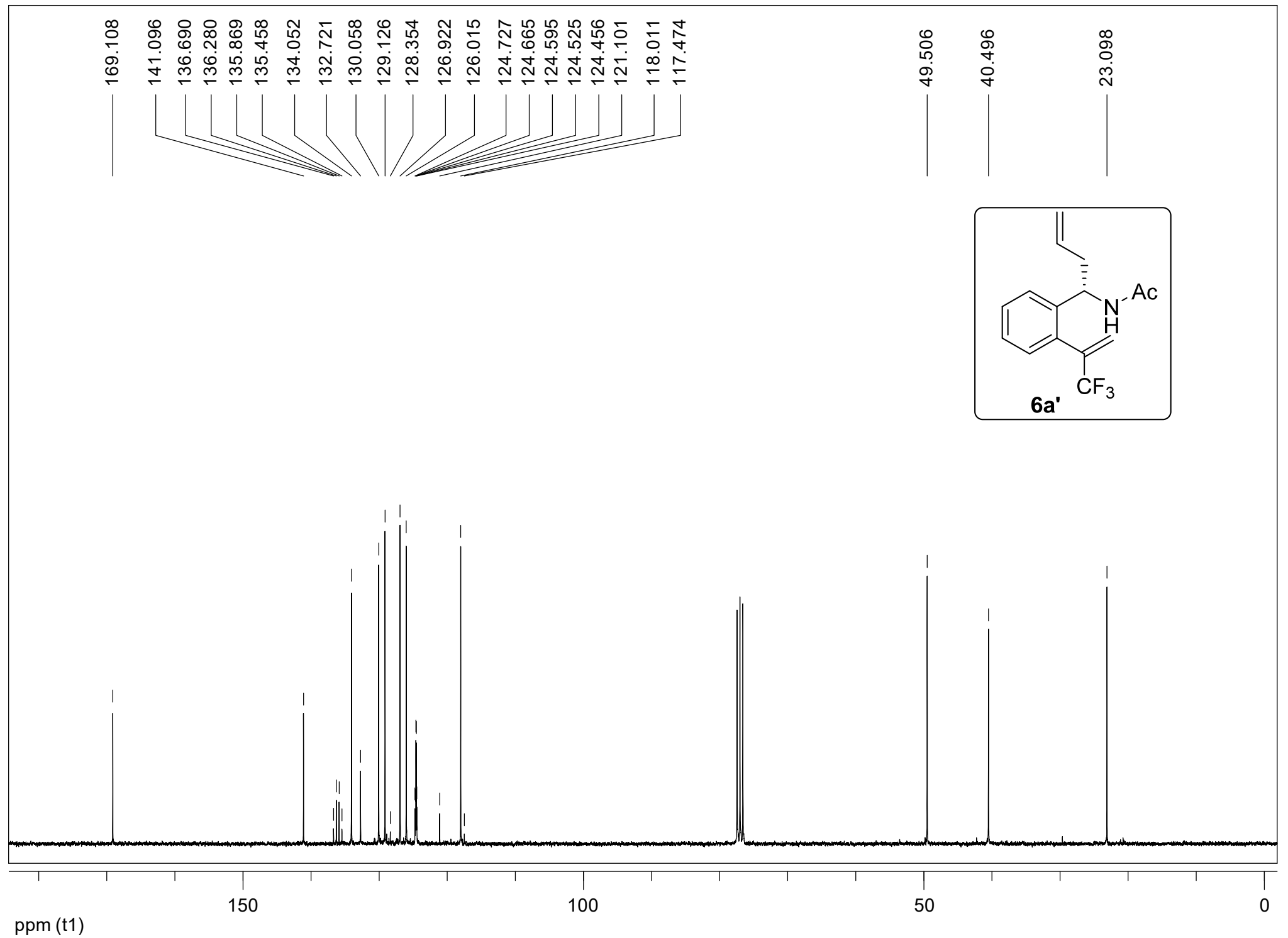




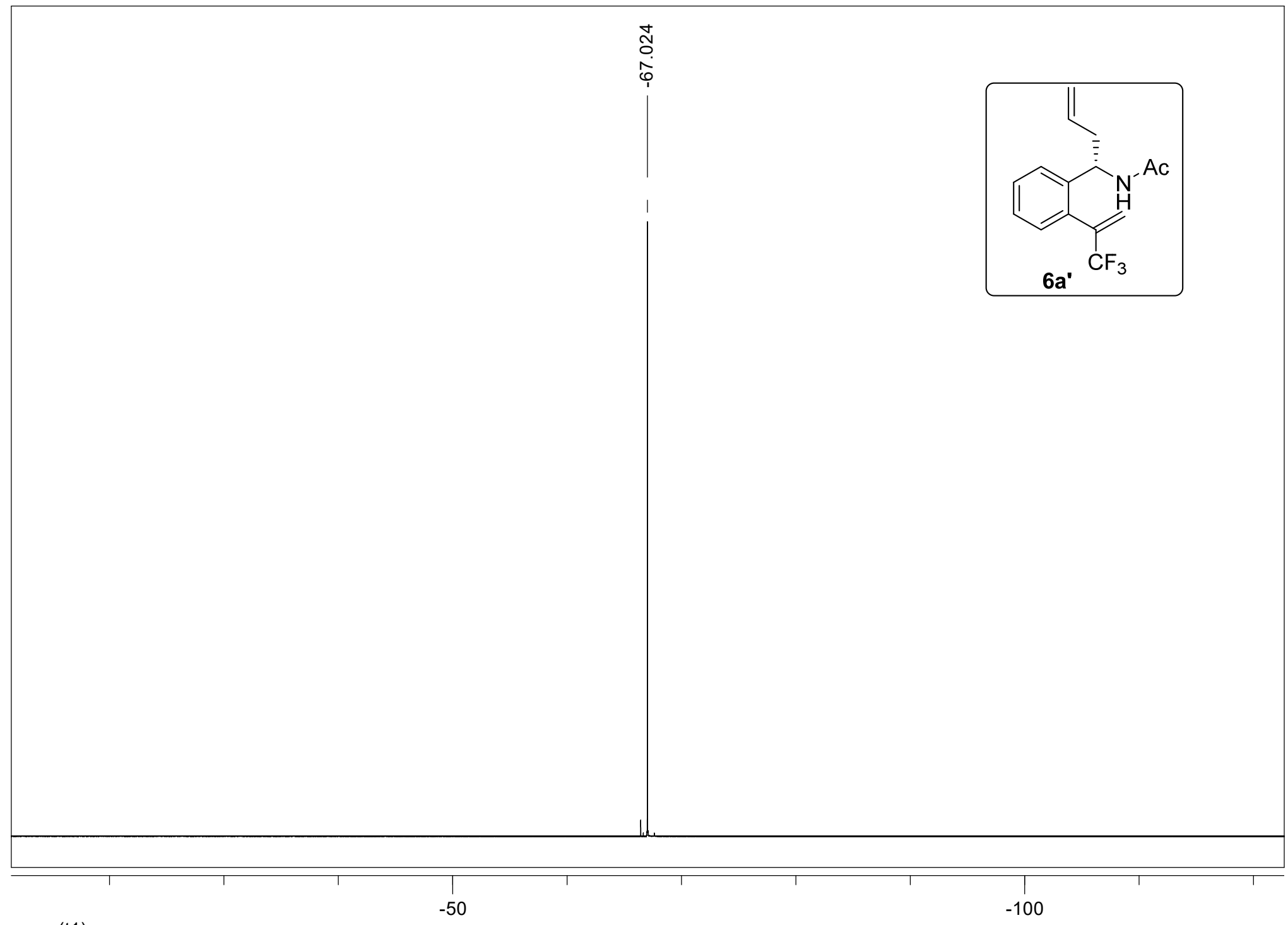

ppm (t1) 


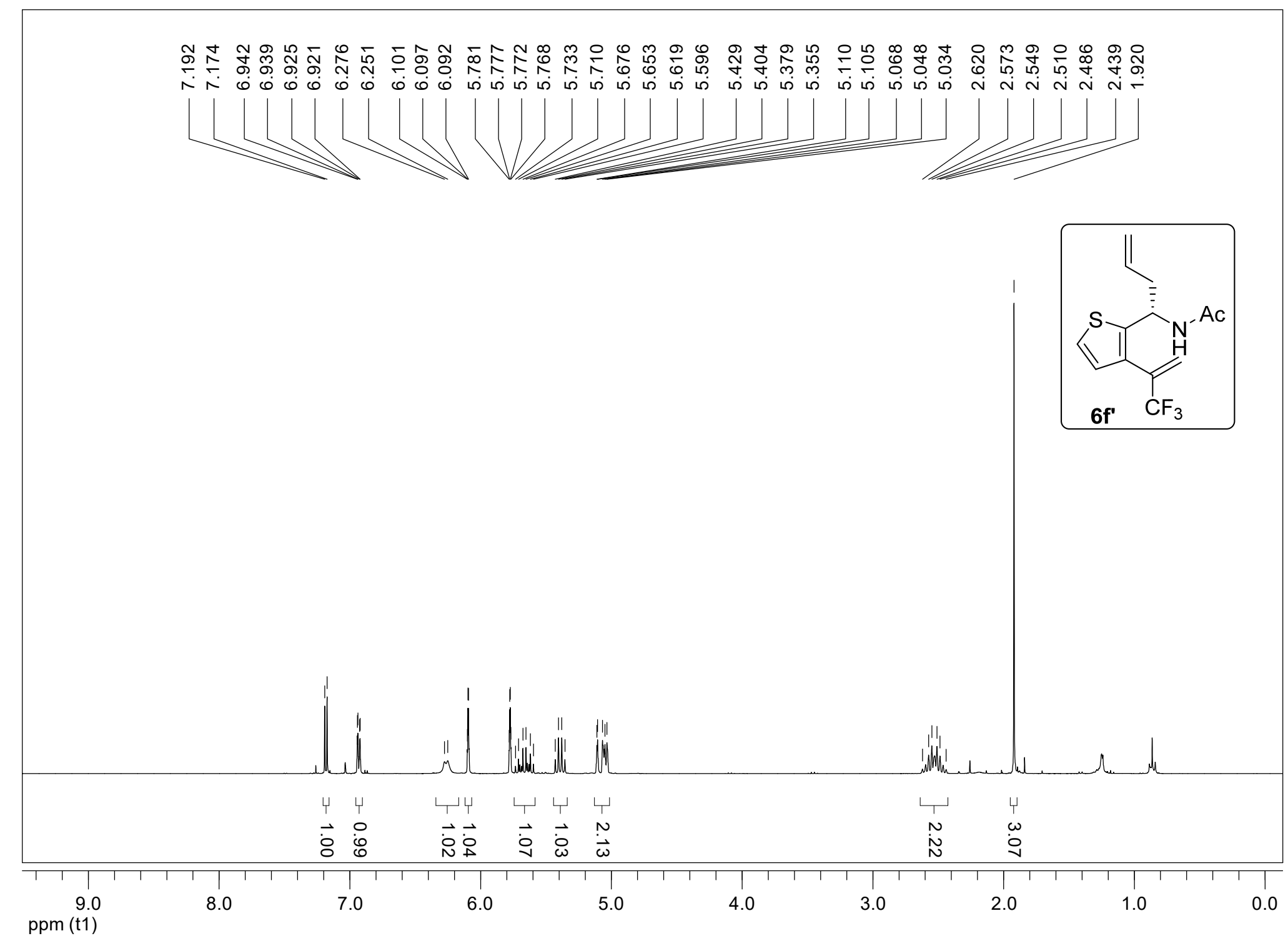




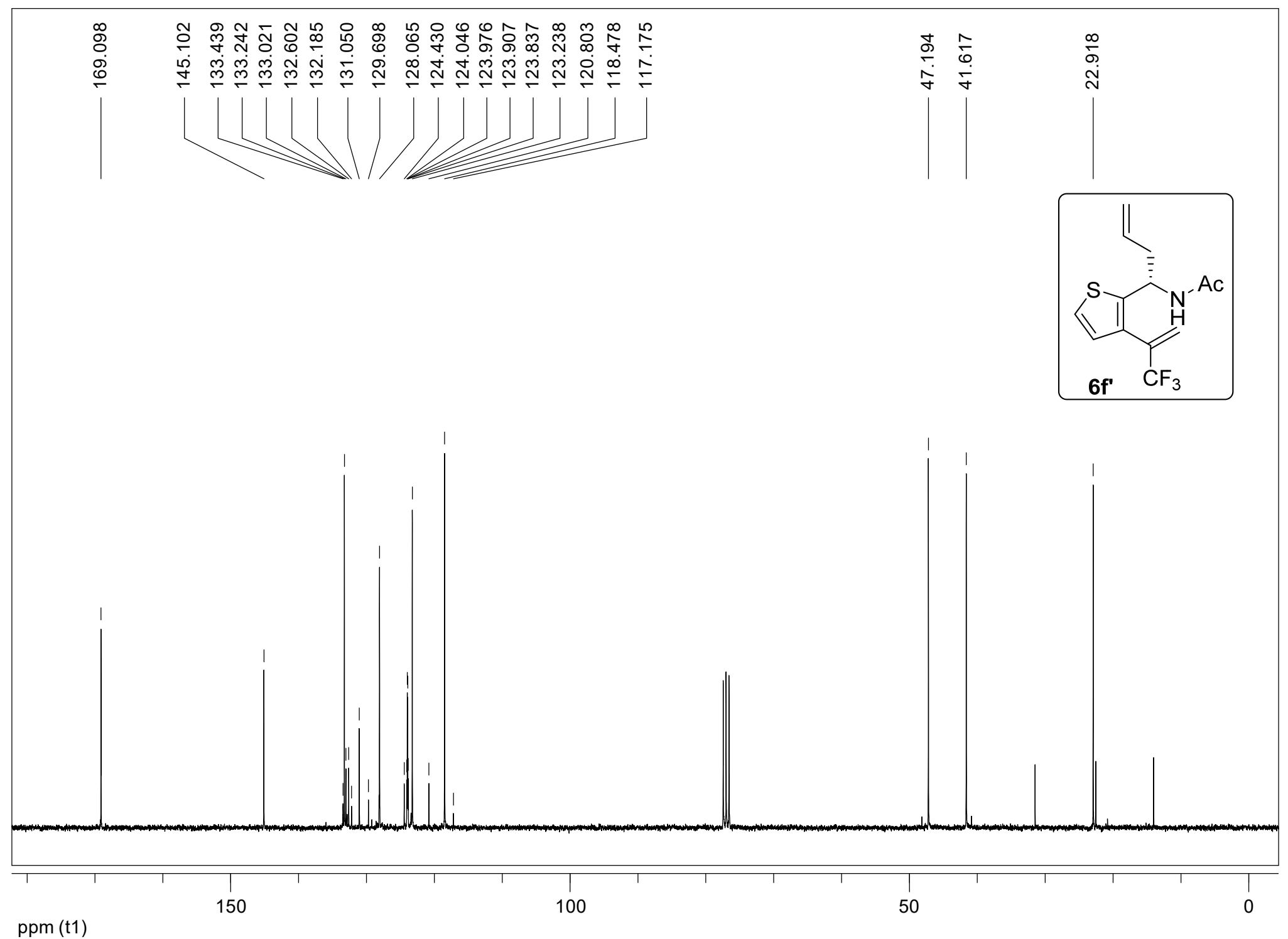




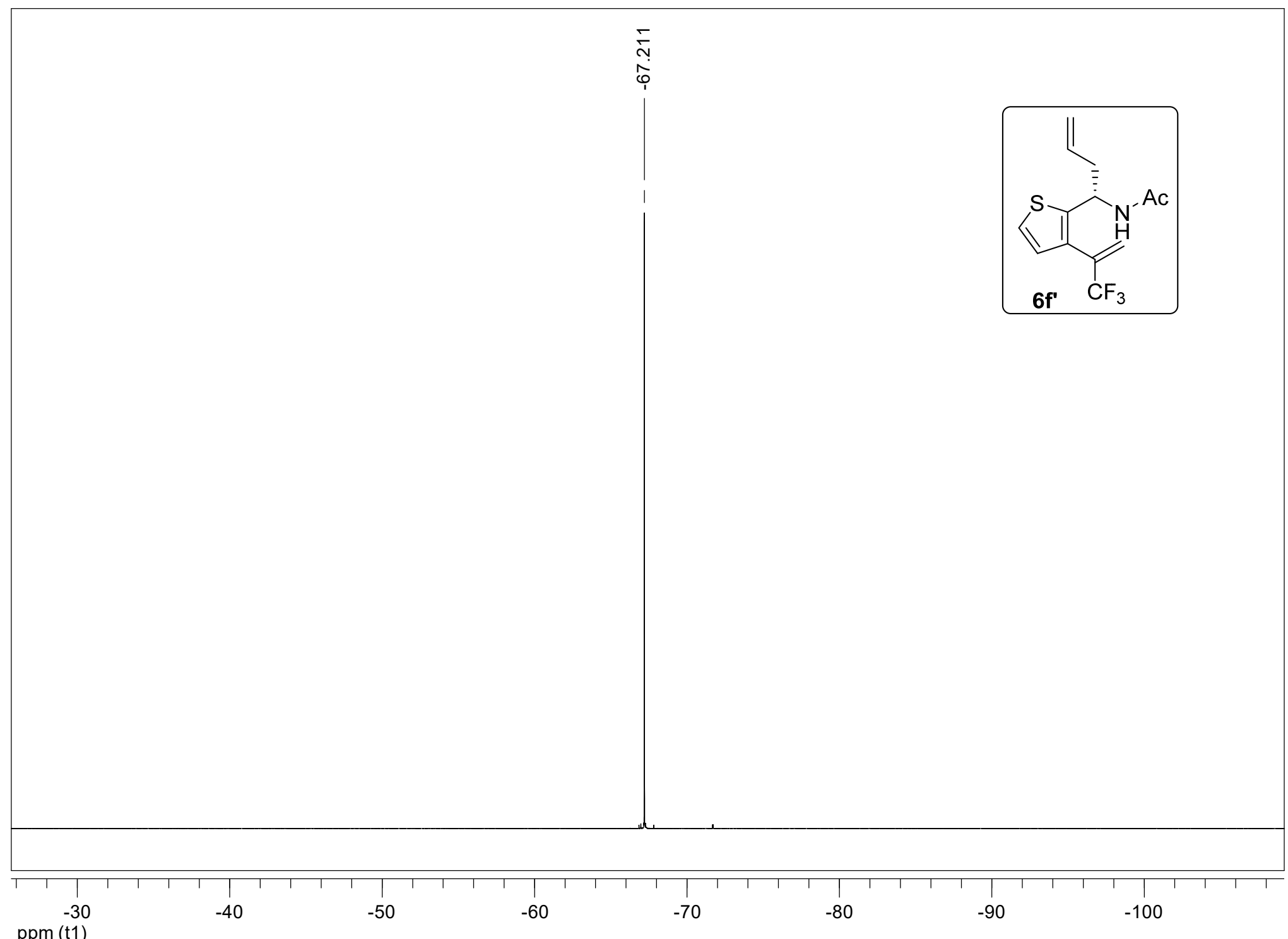




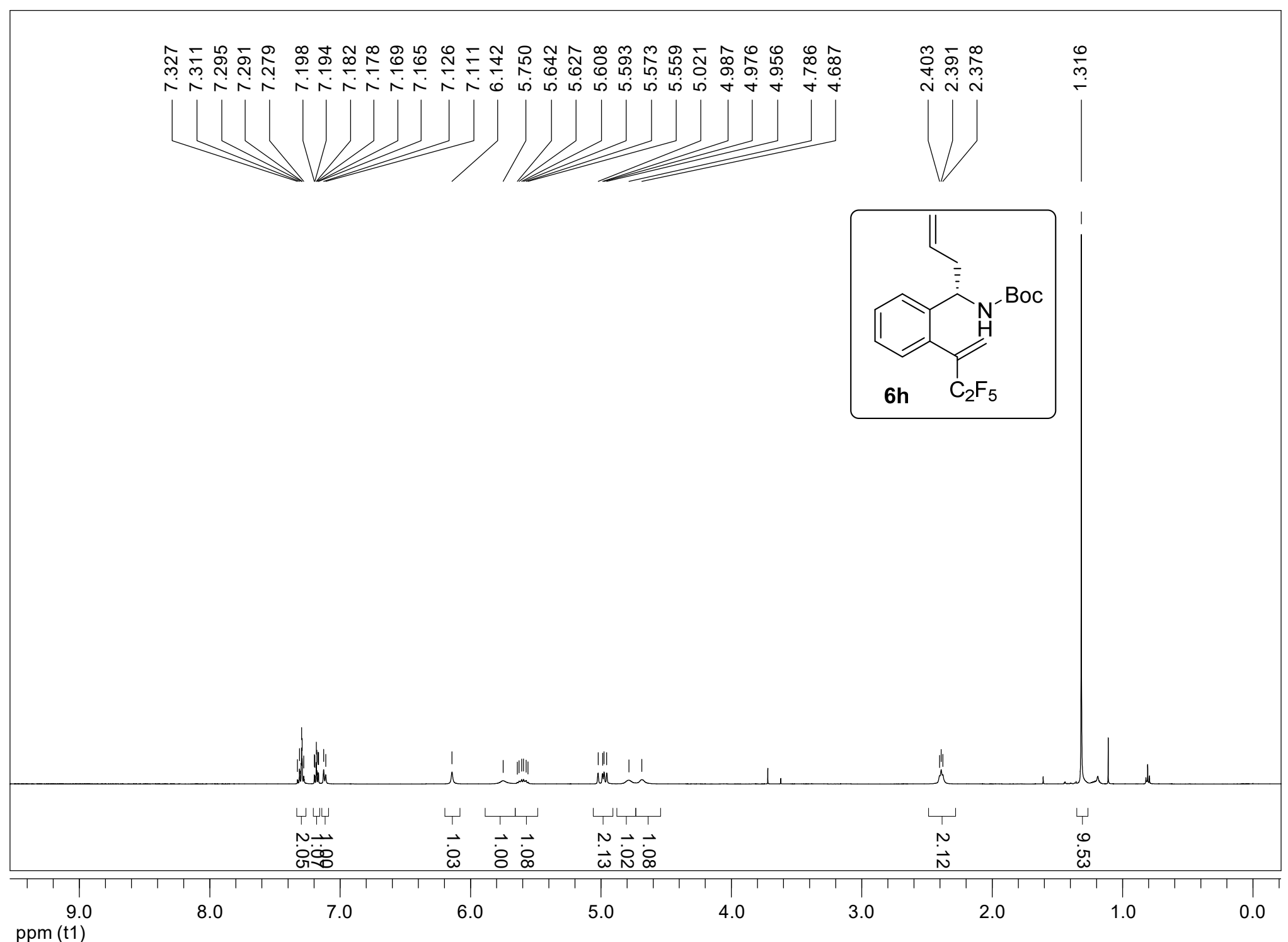




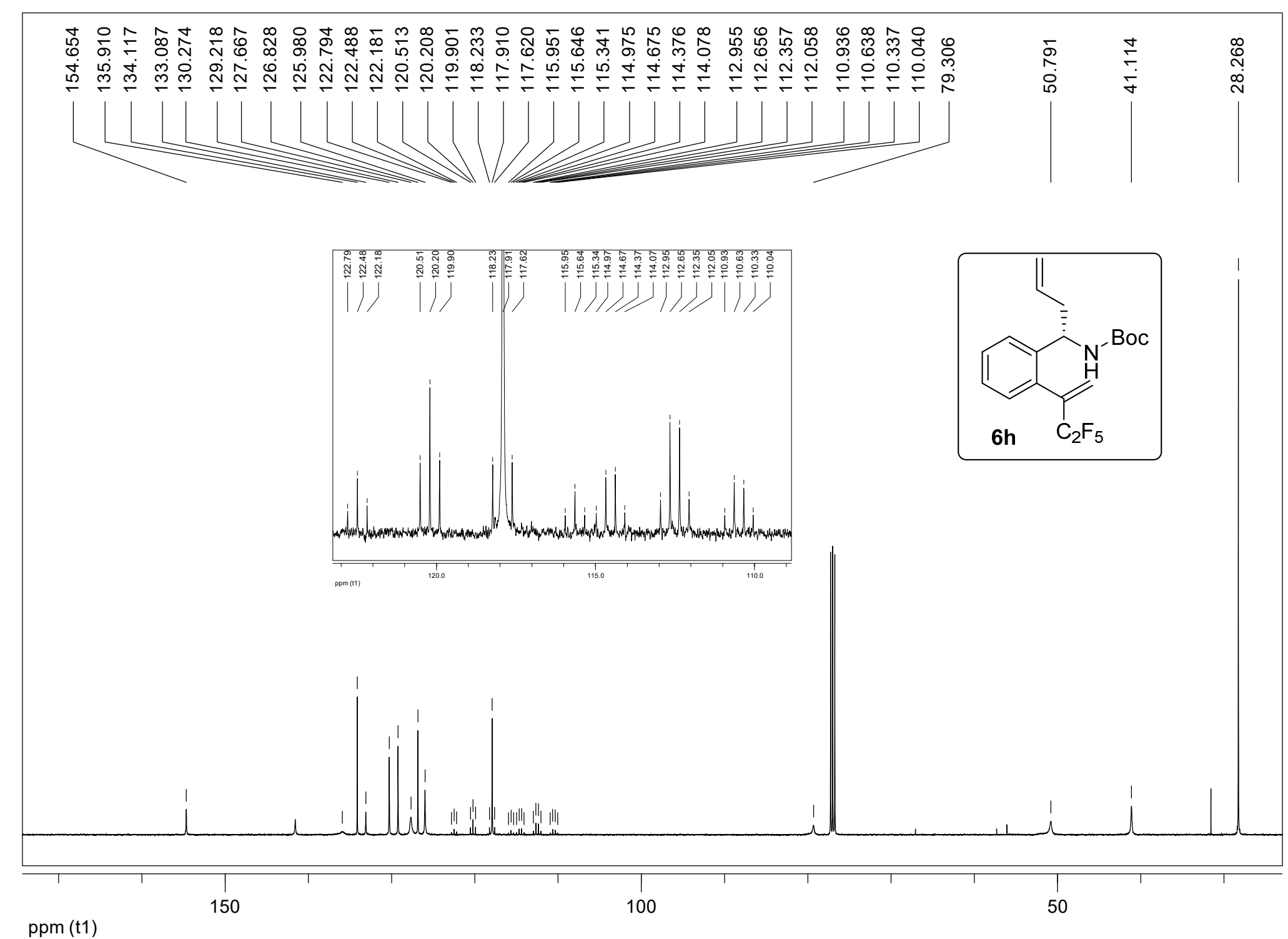




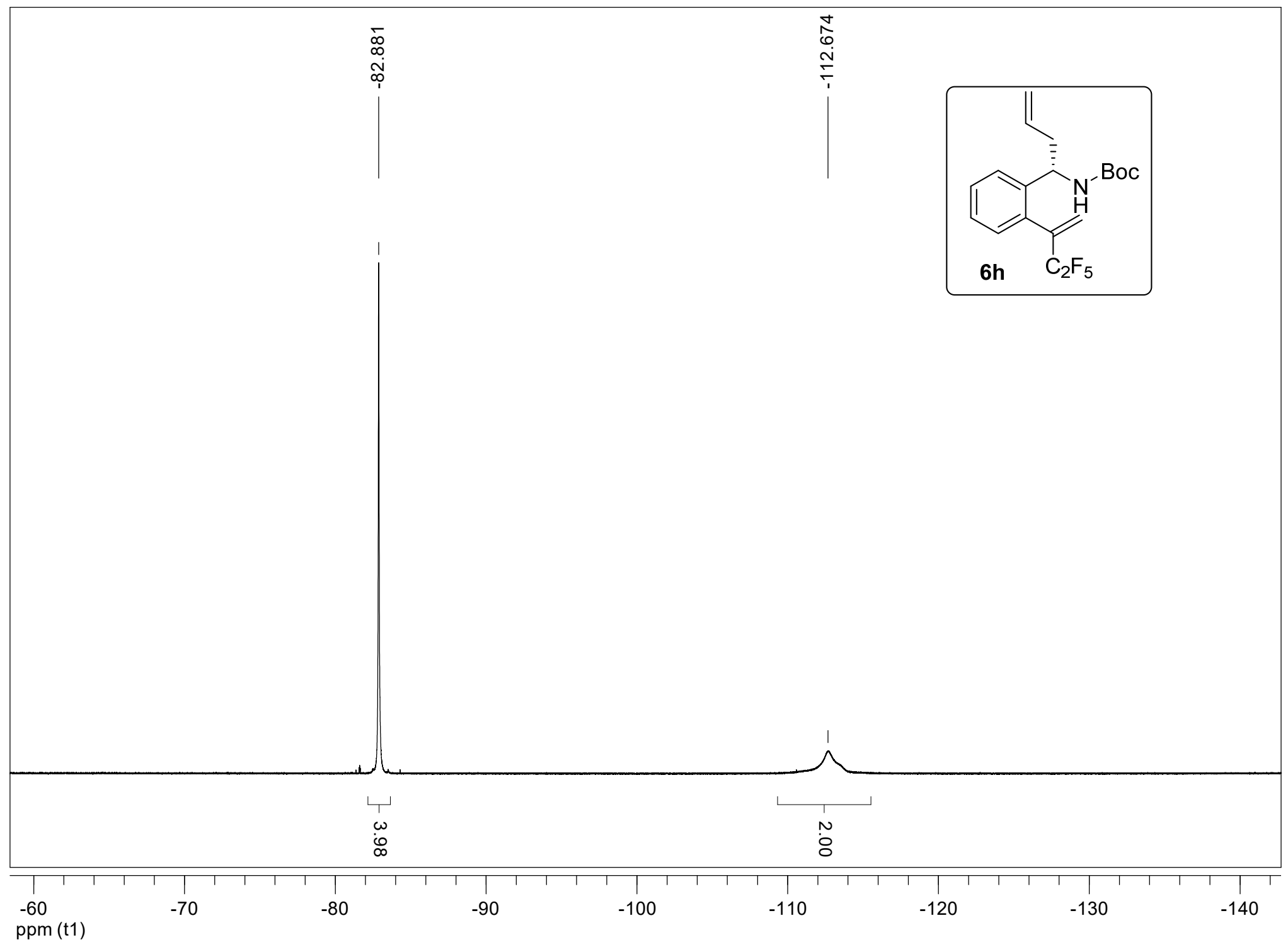




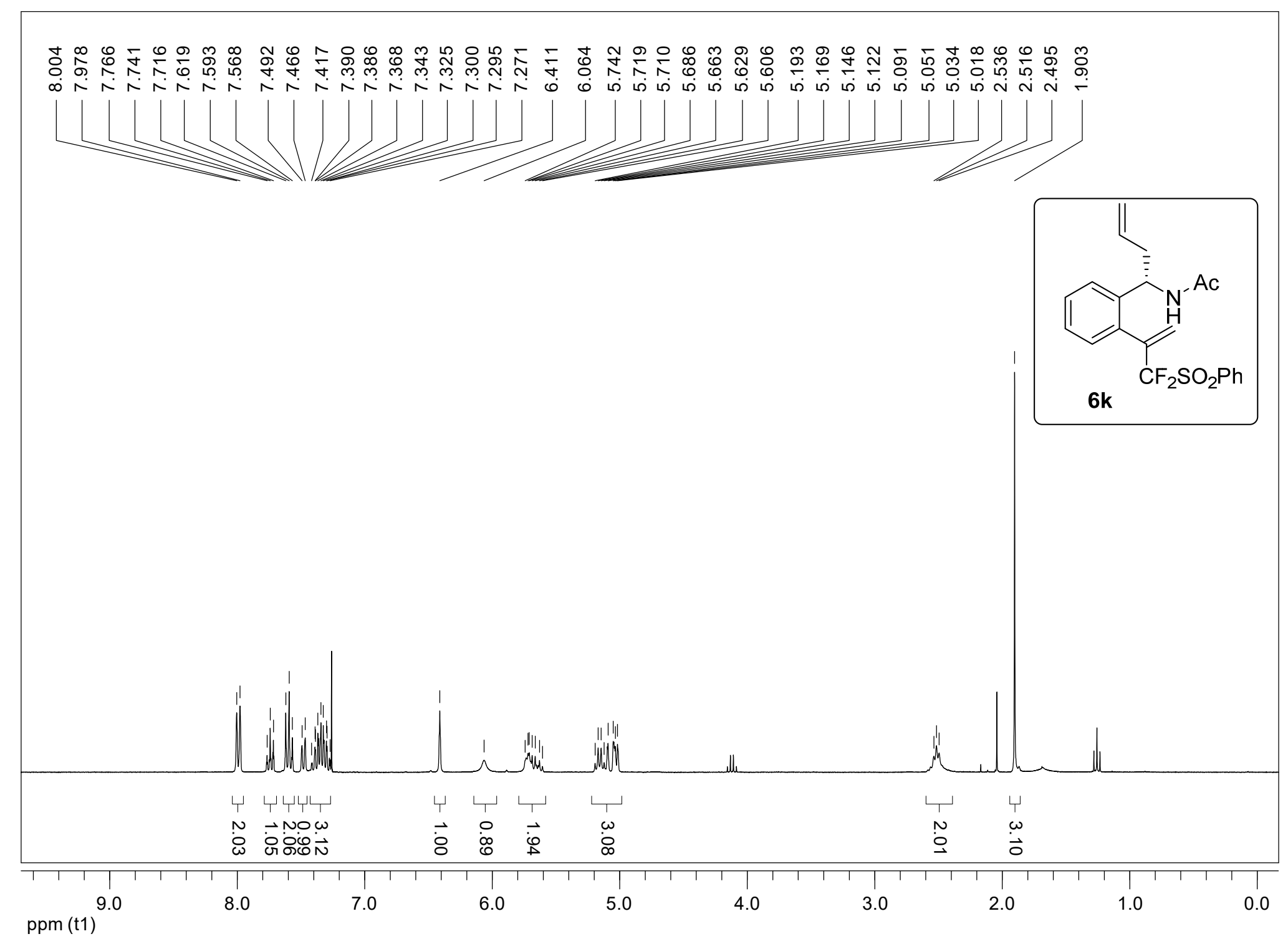




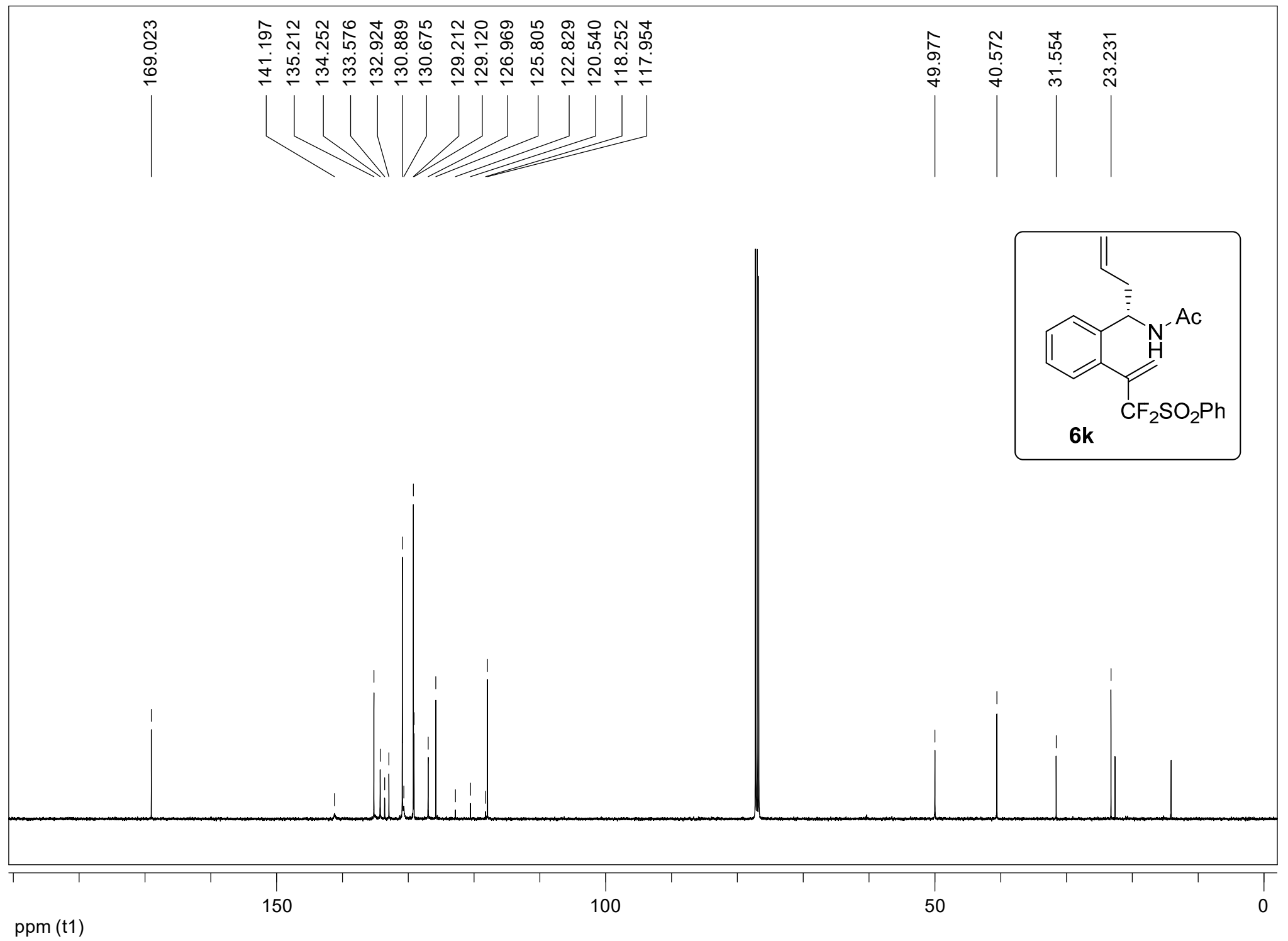




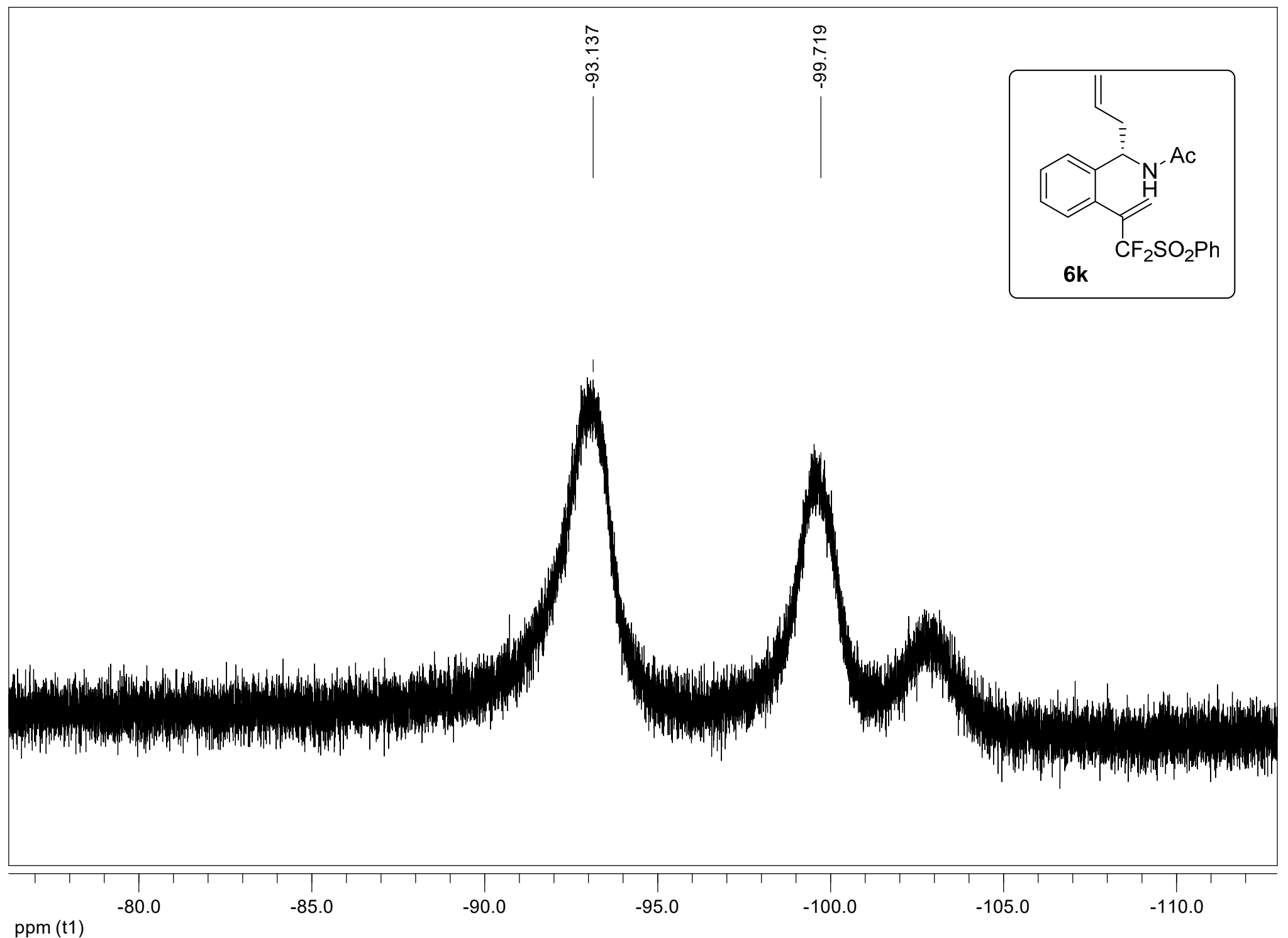




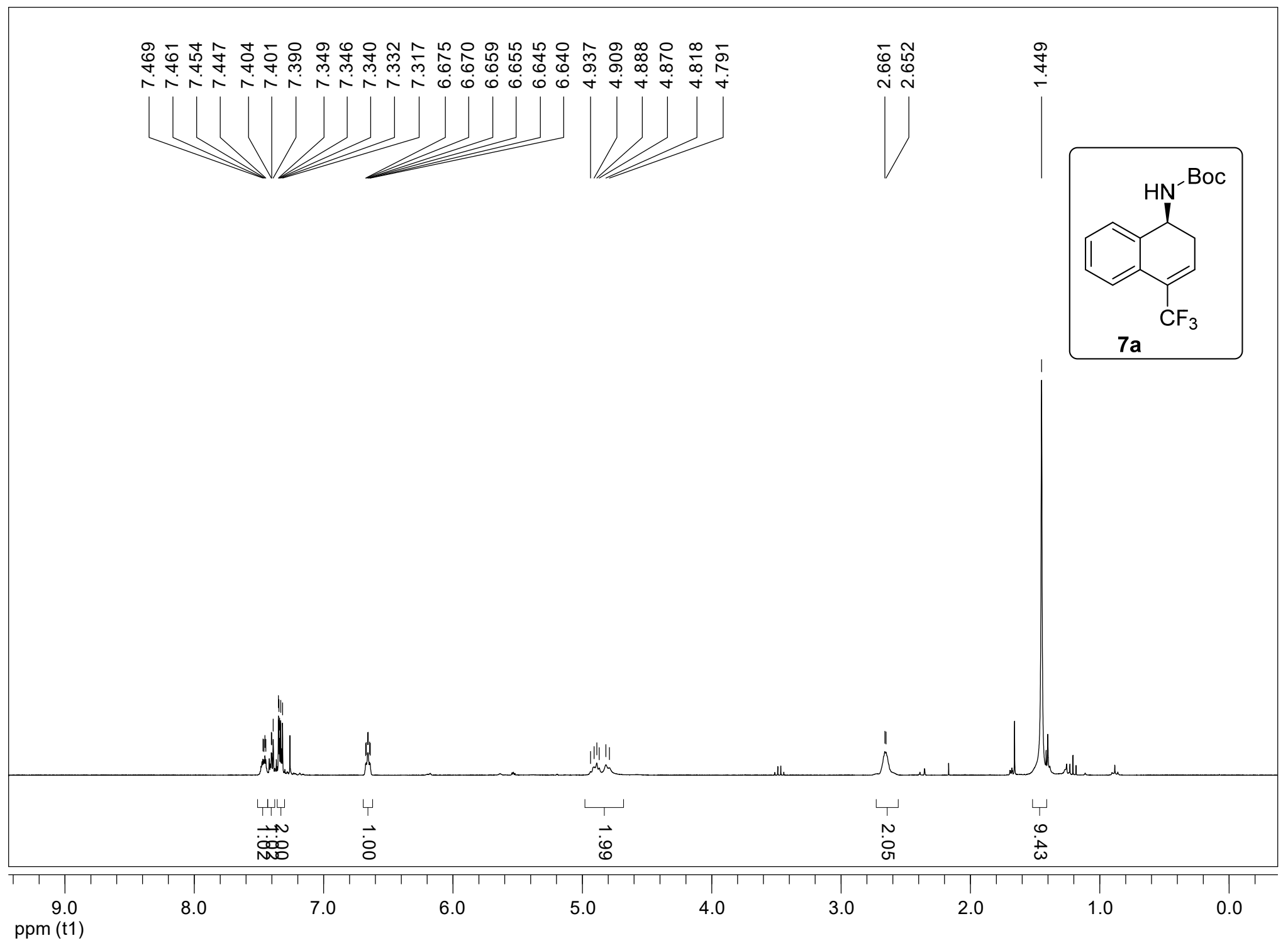




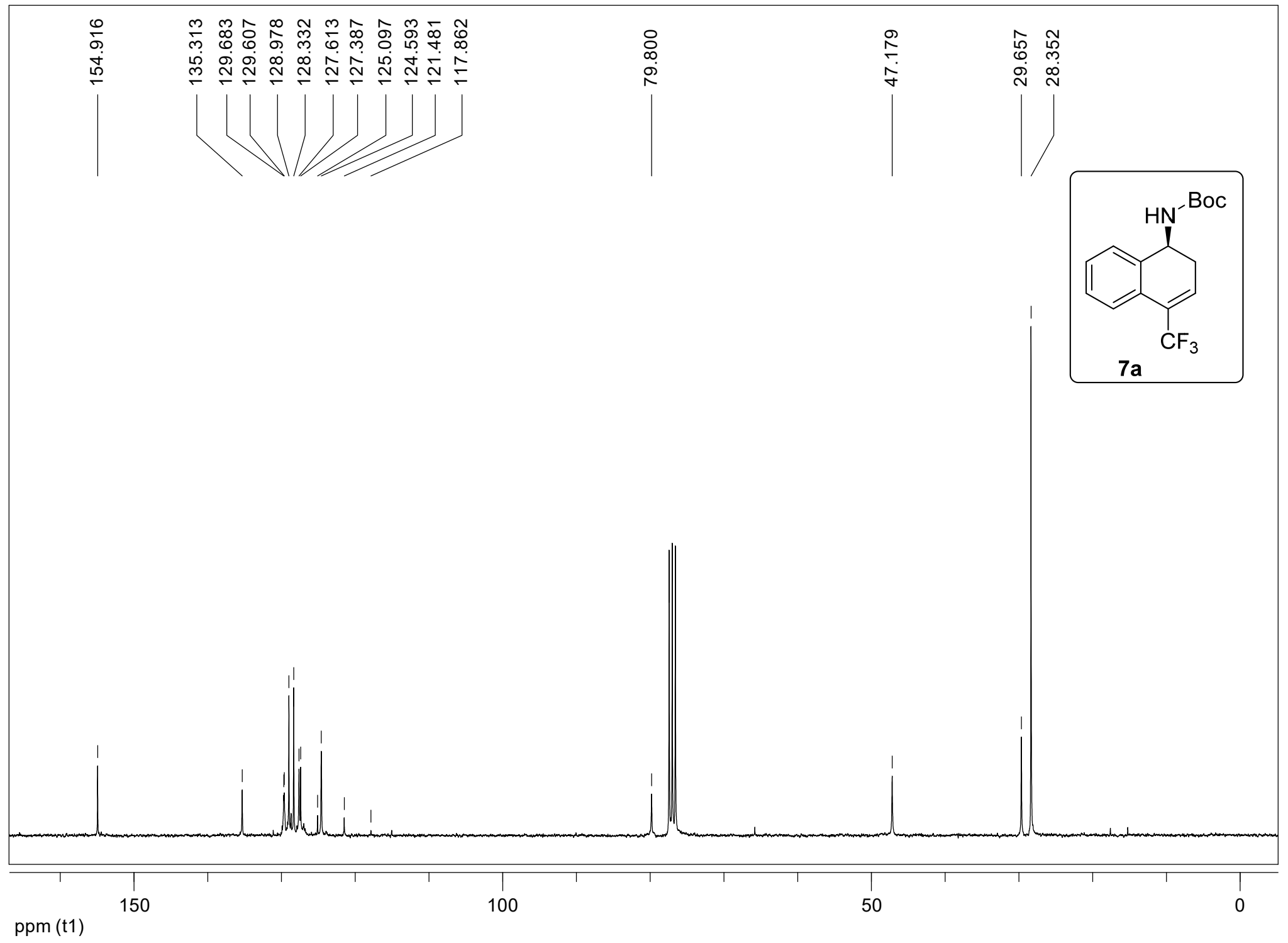




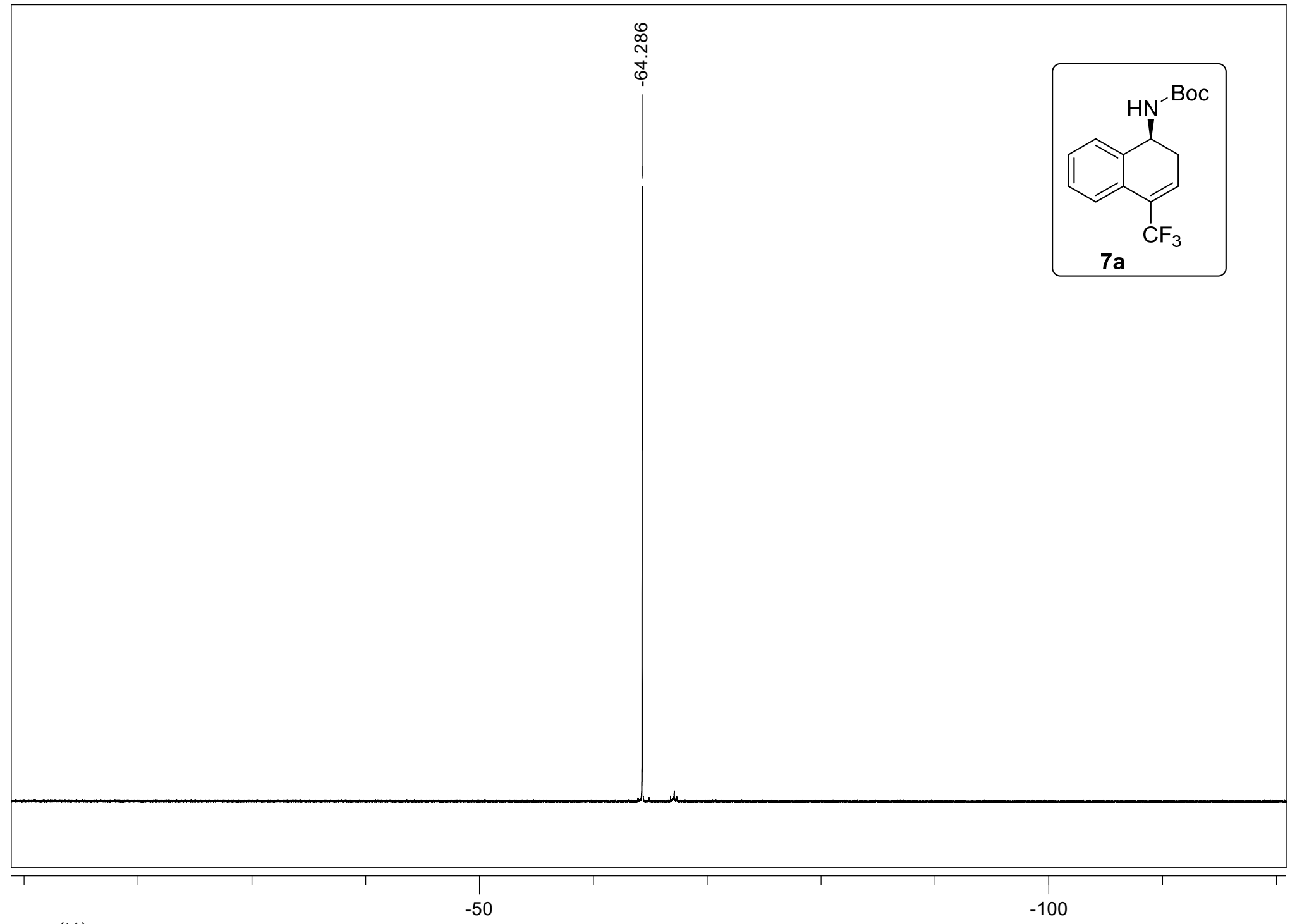

ppm (t1) 


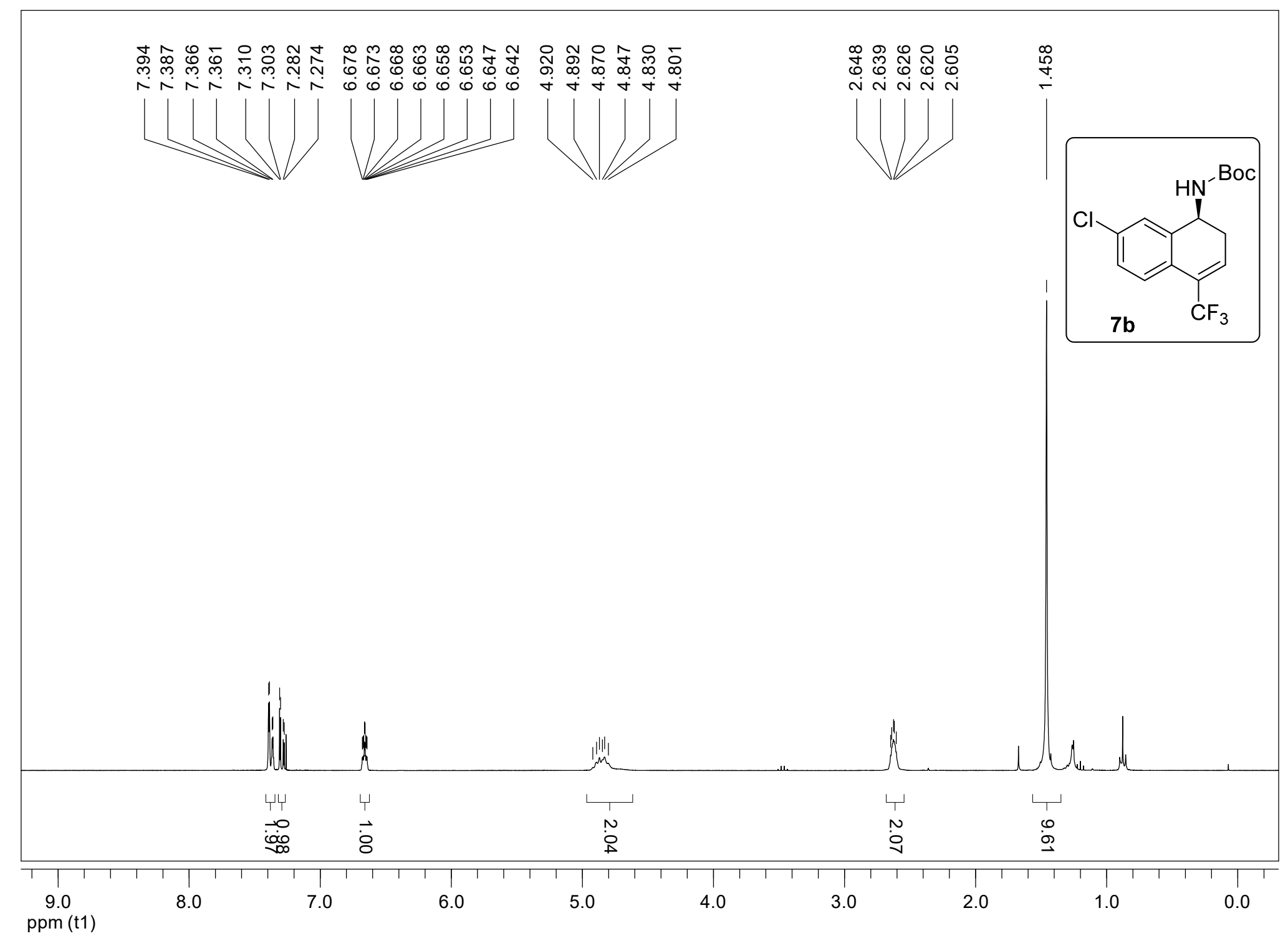




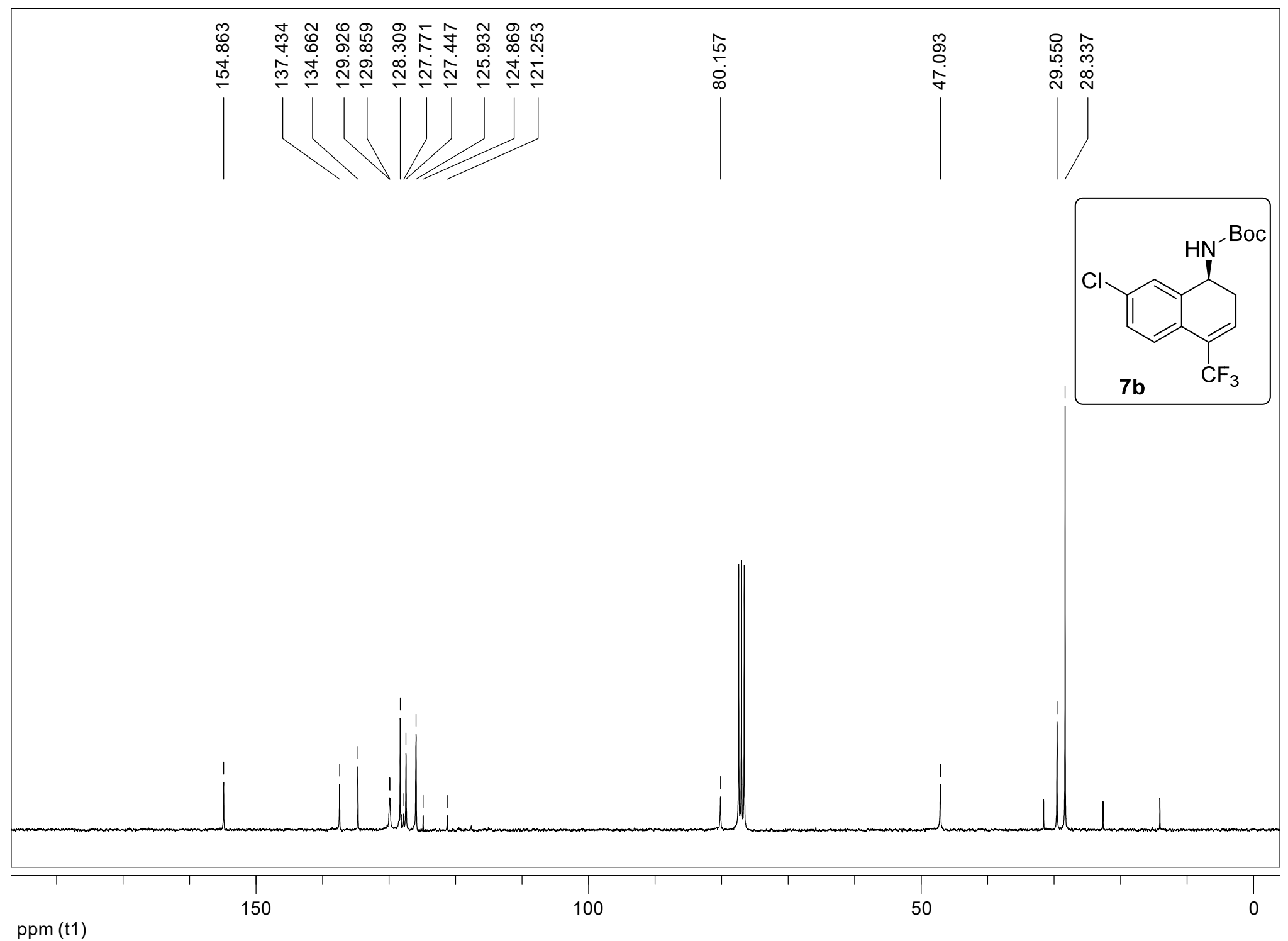




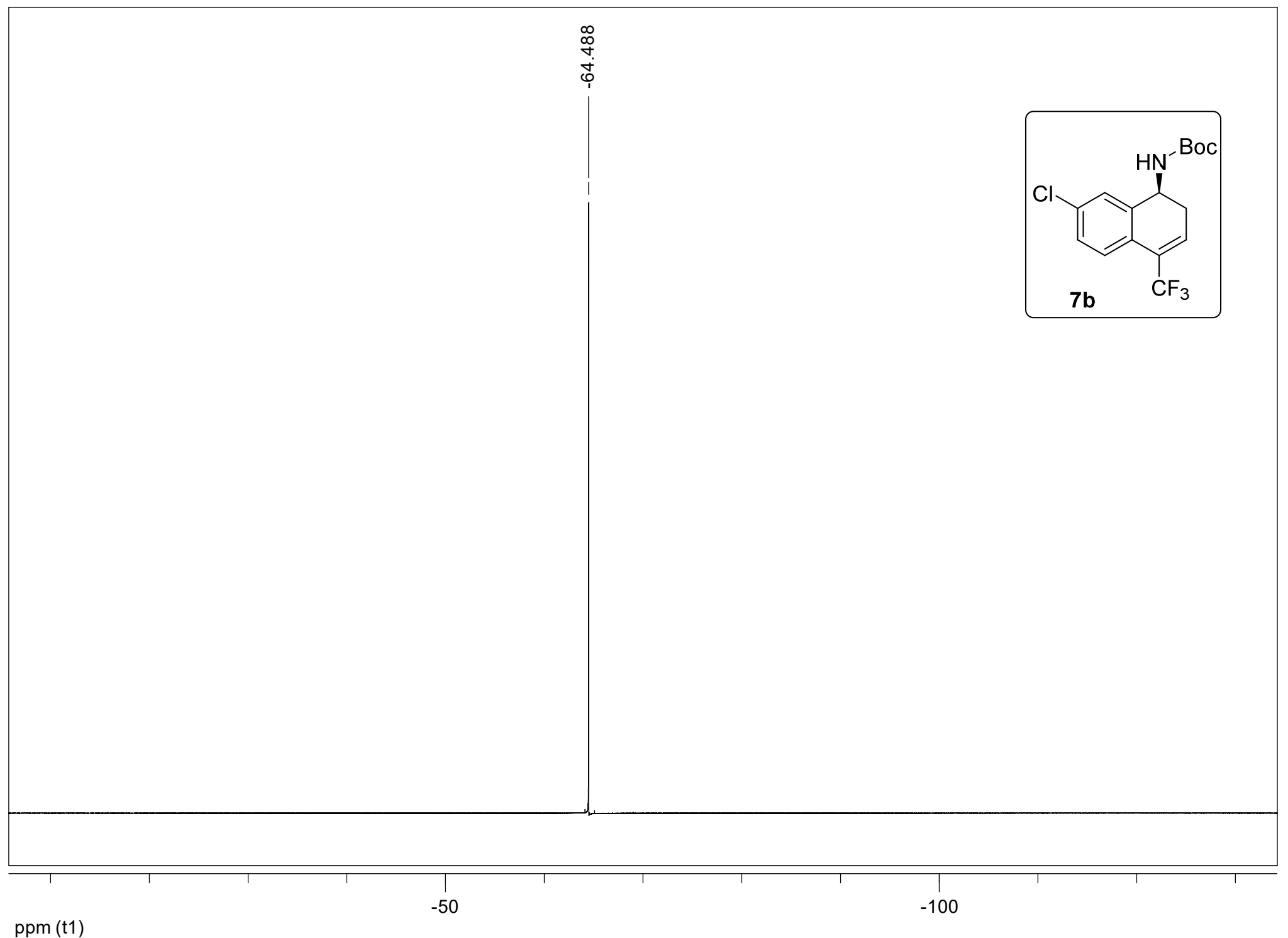




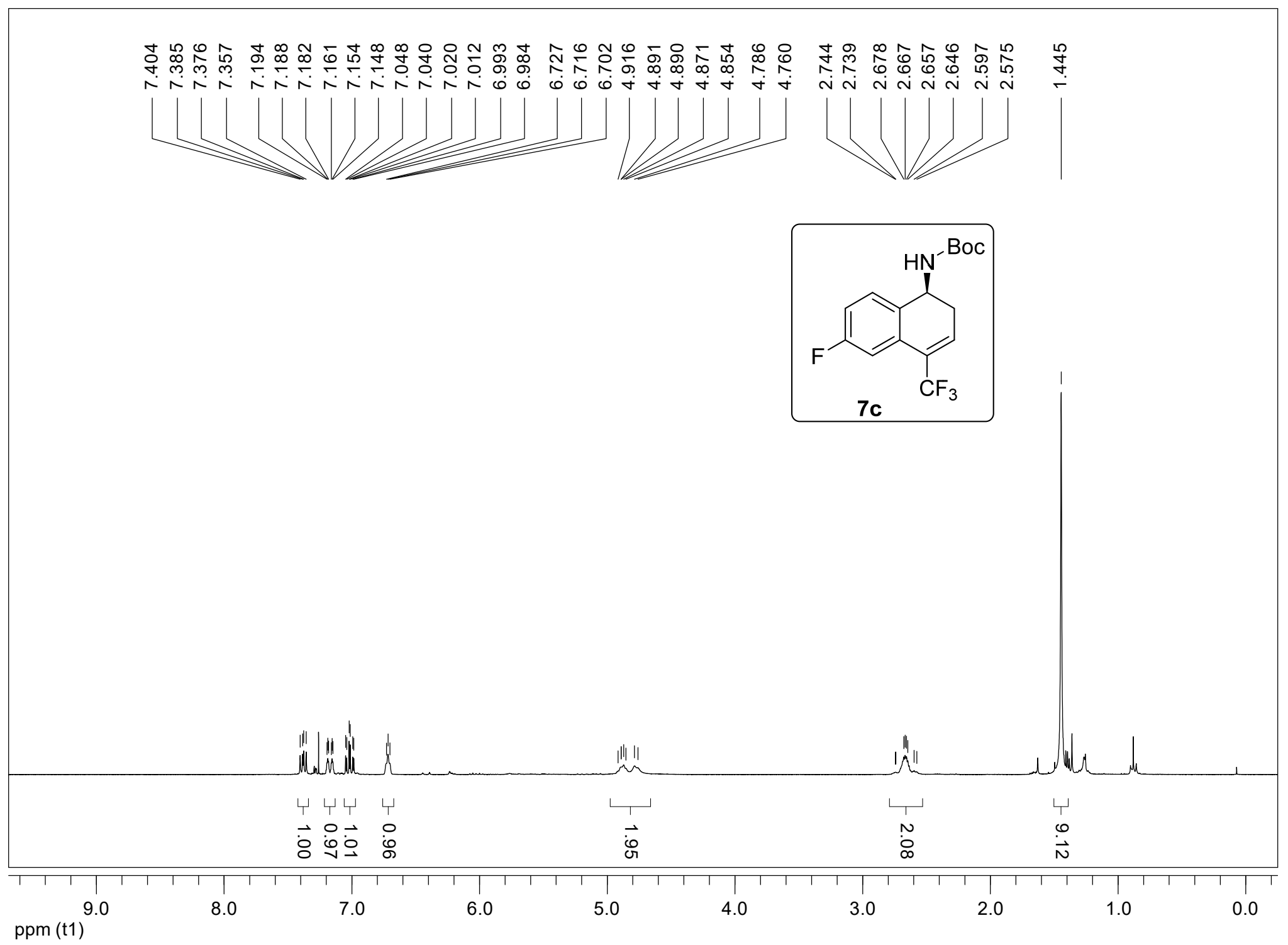




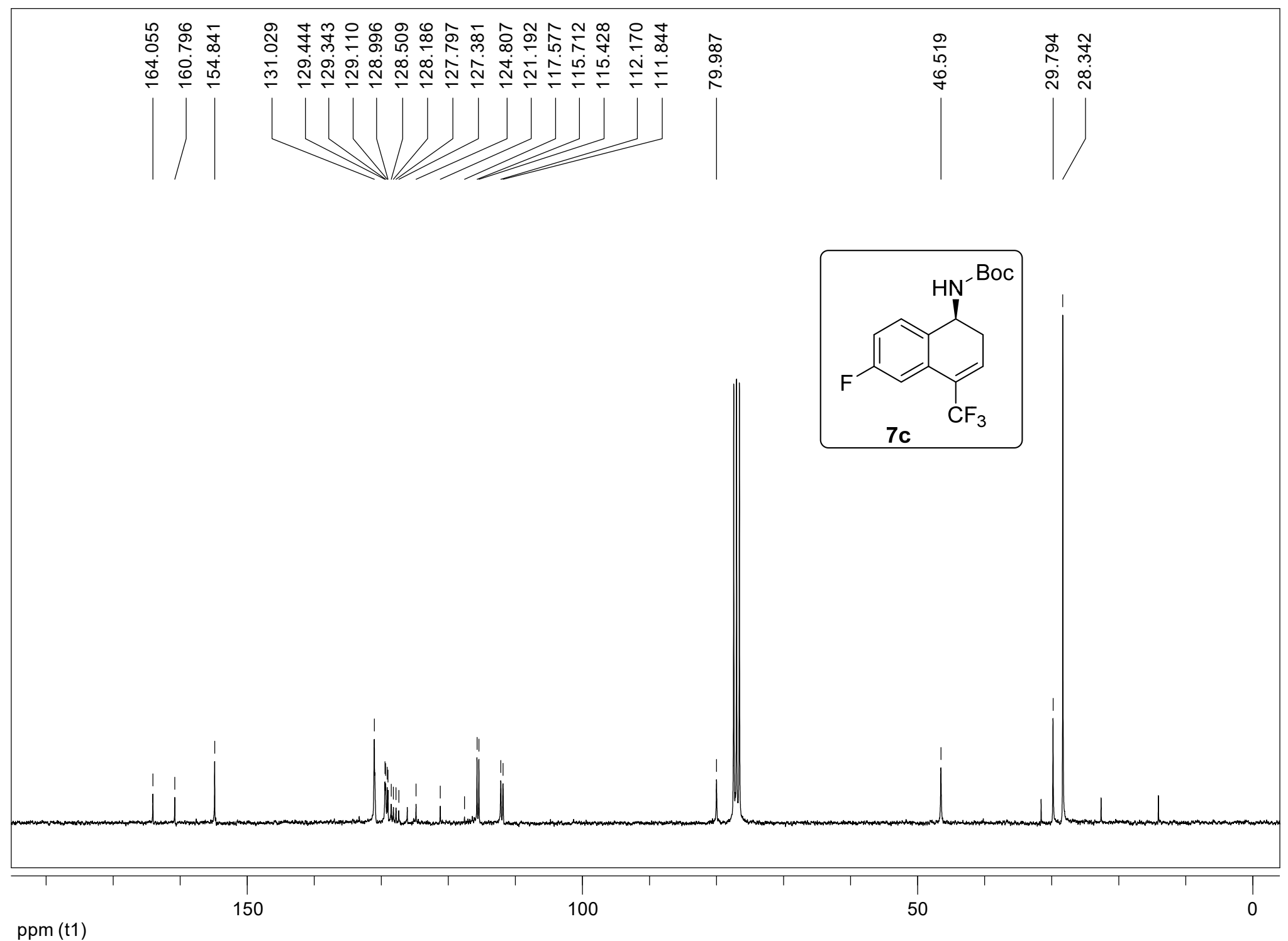




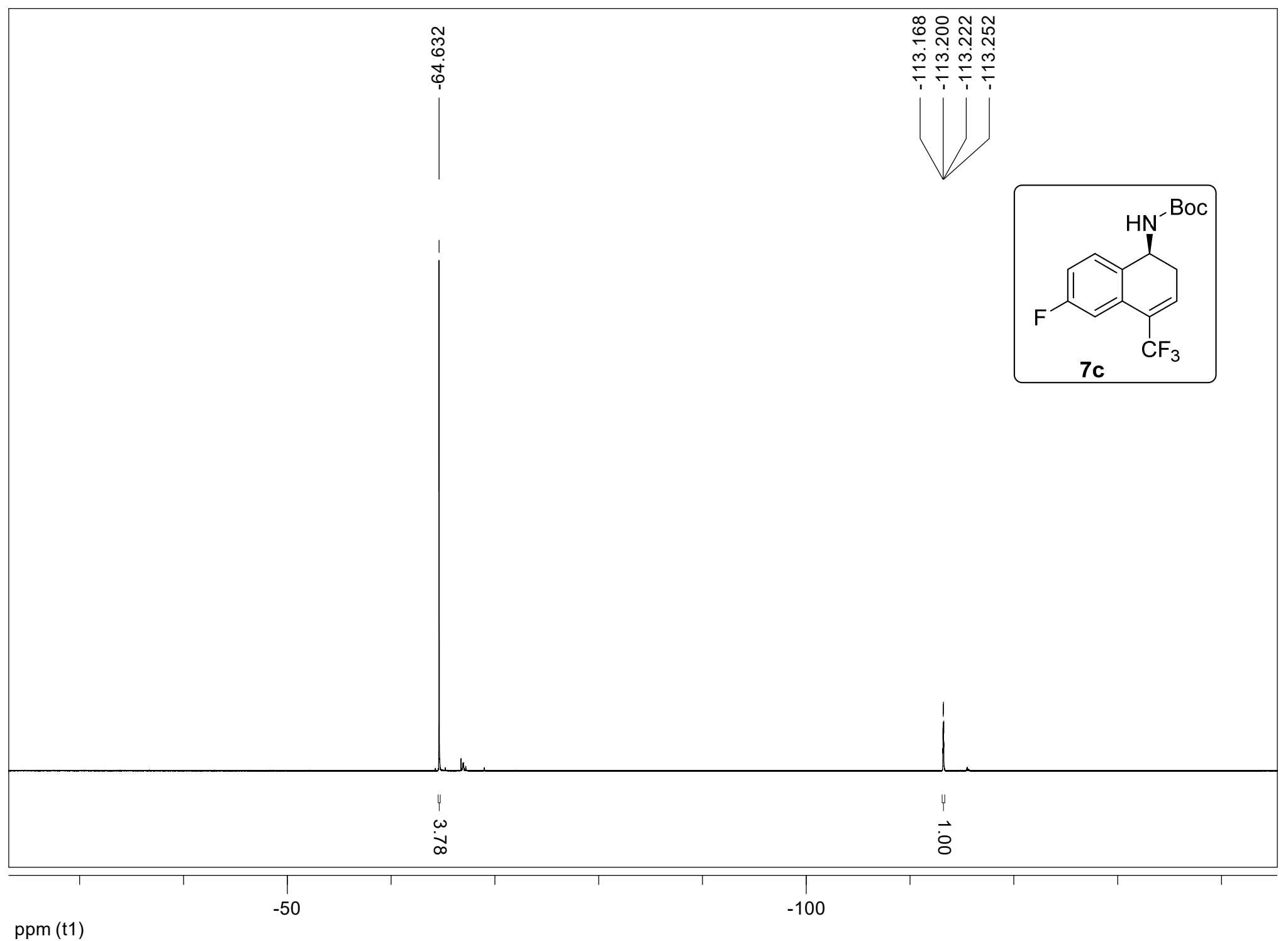




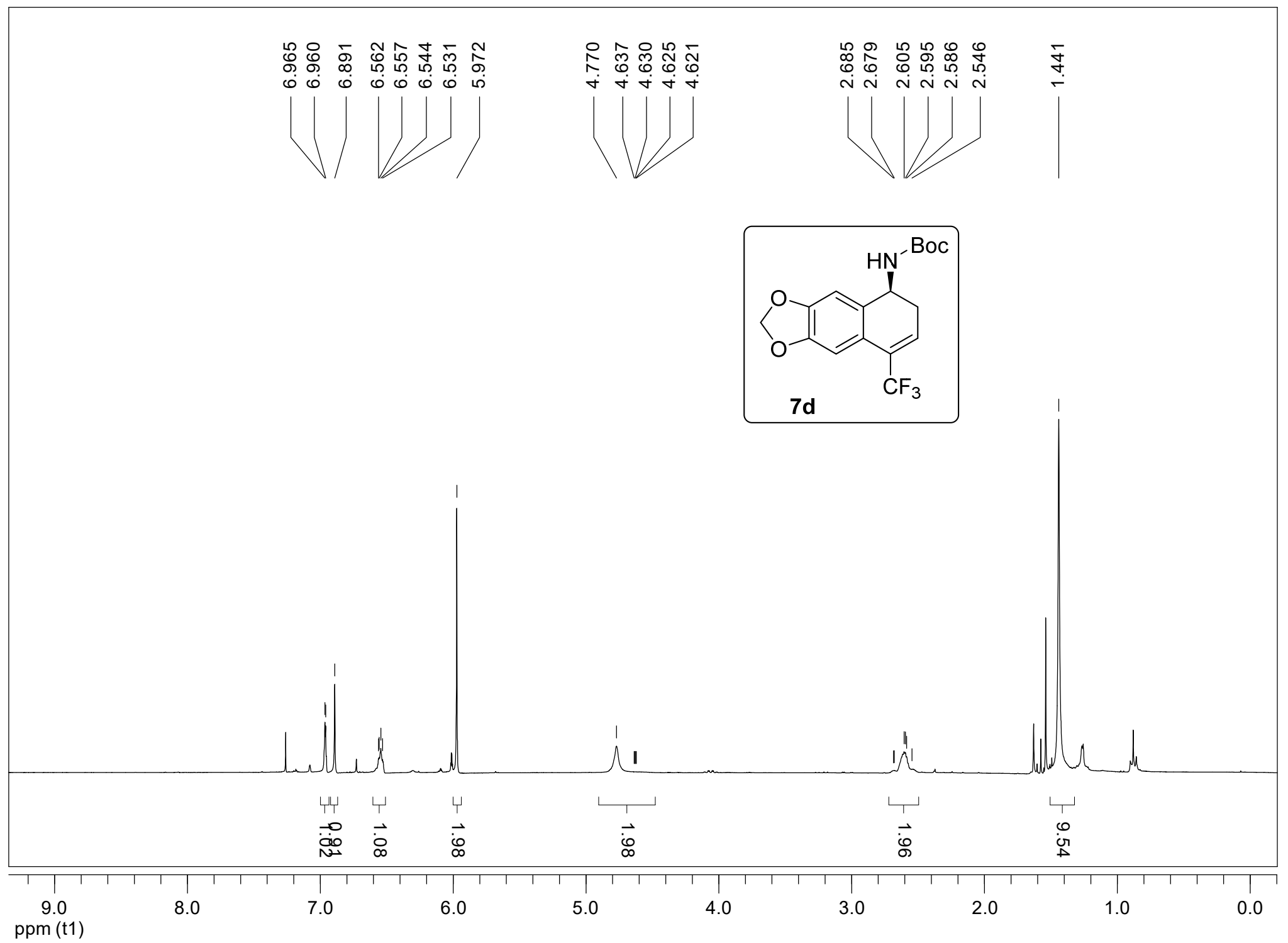




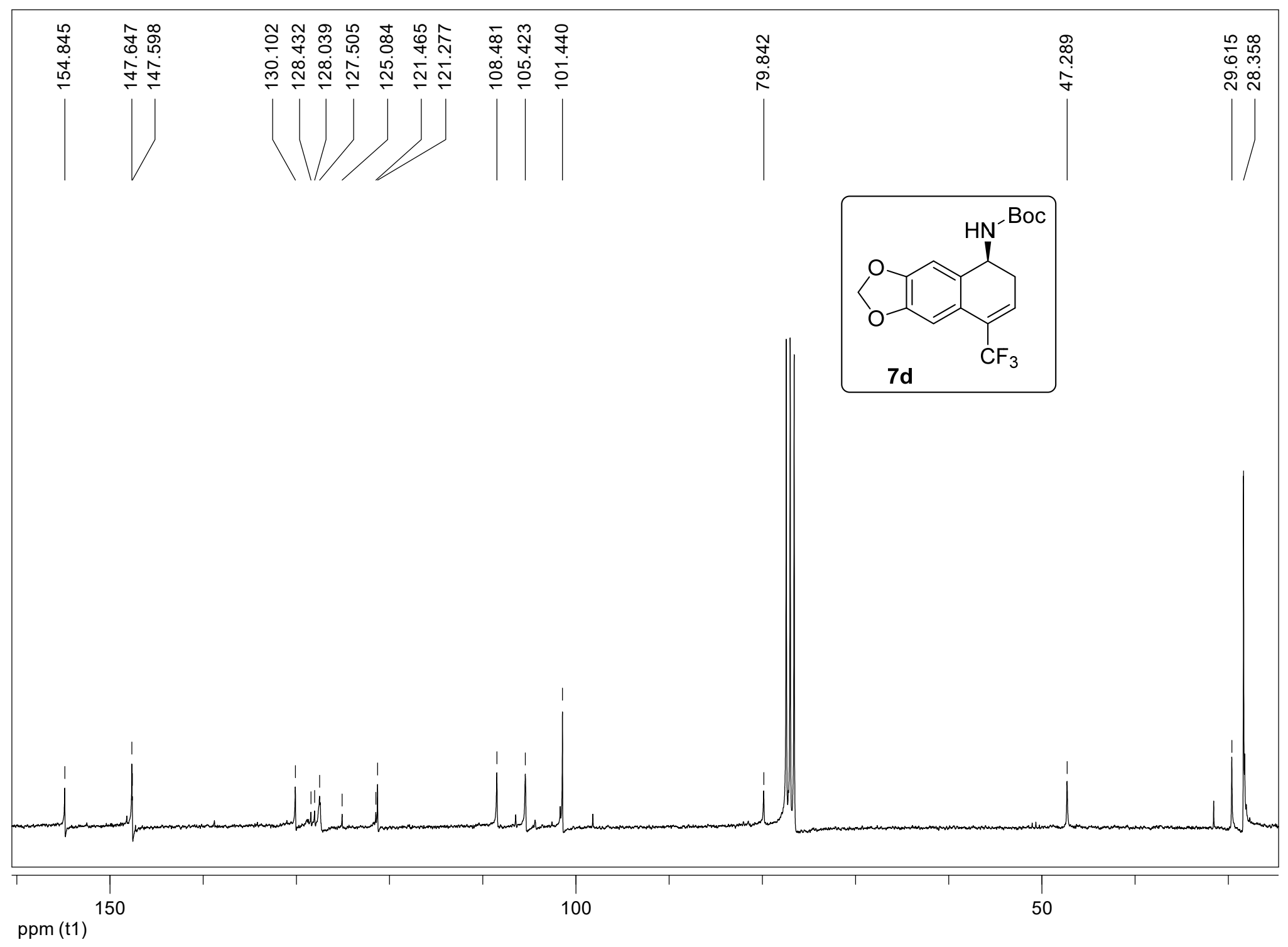




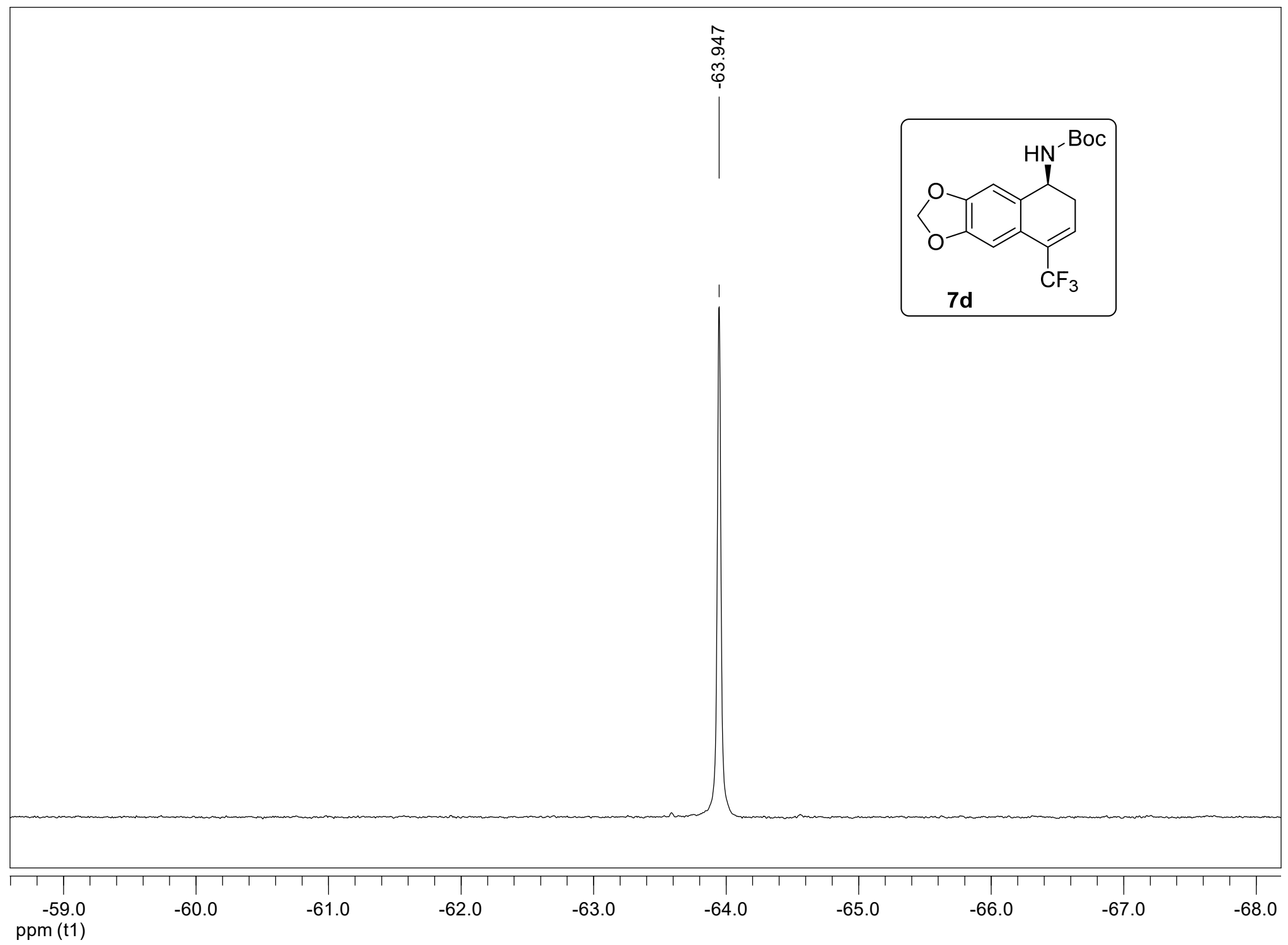




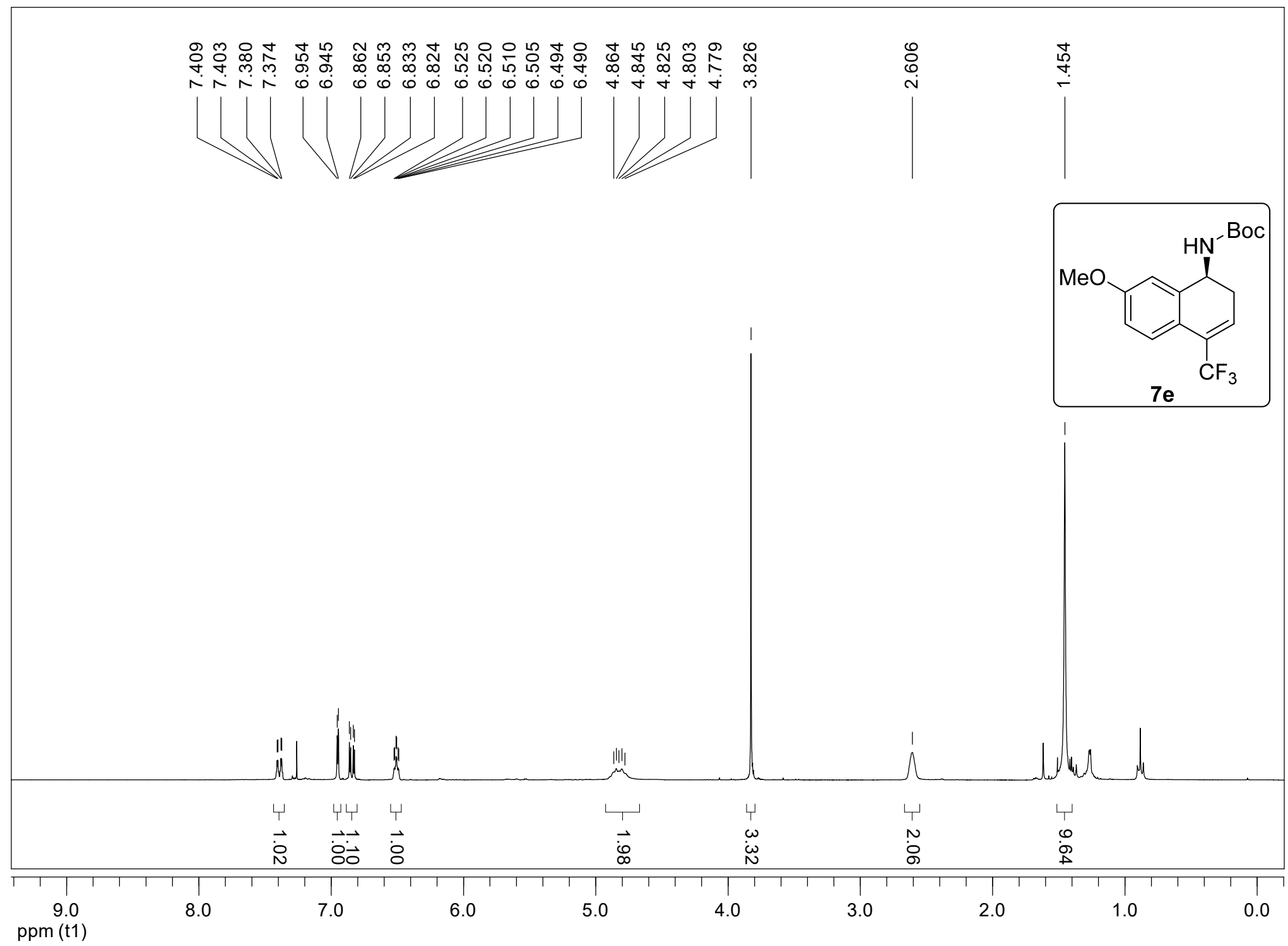




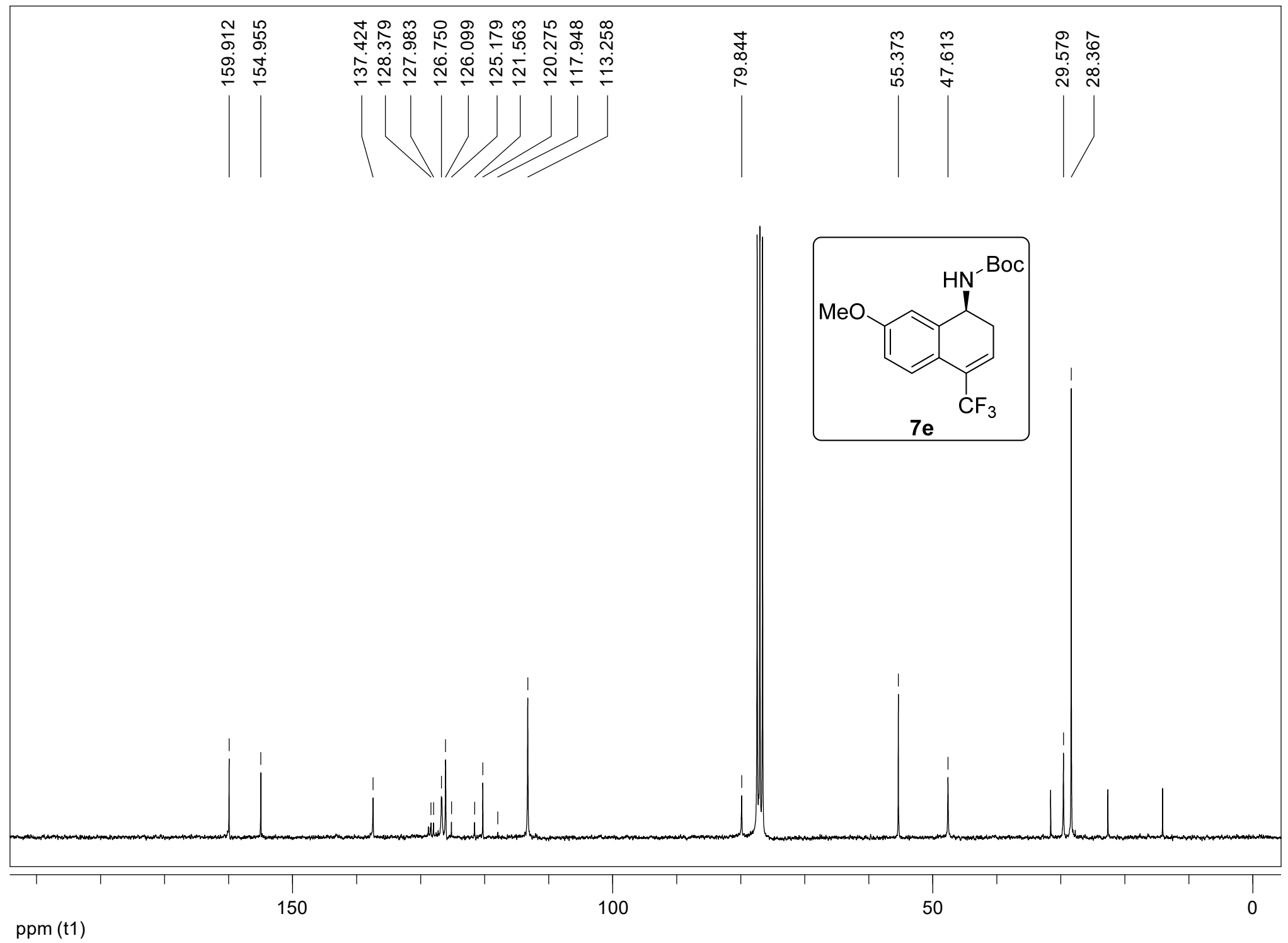




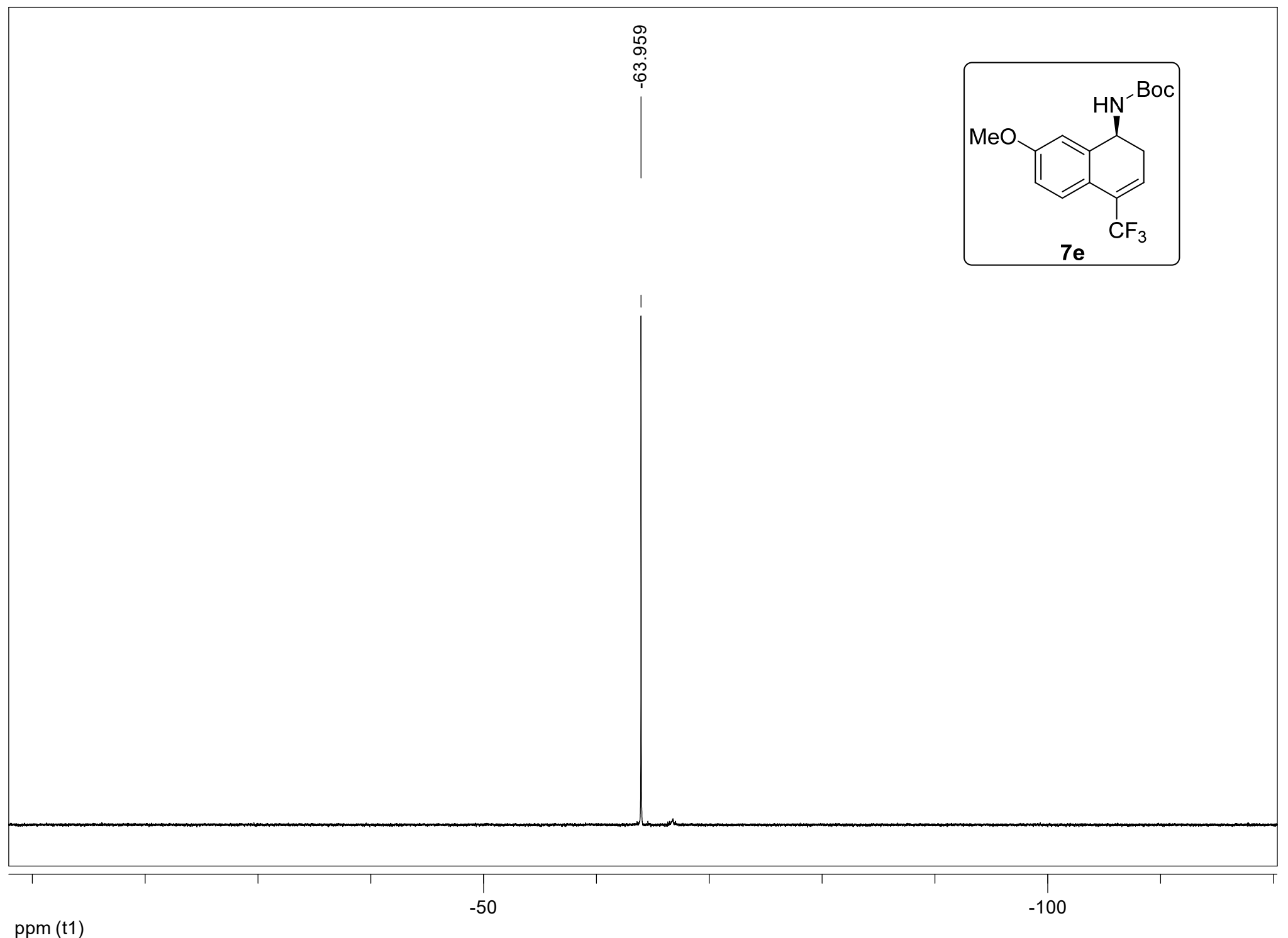




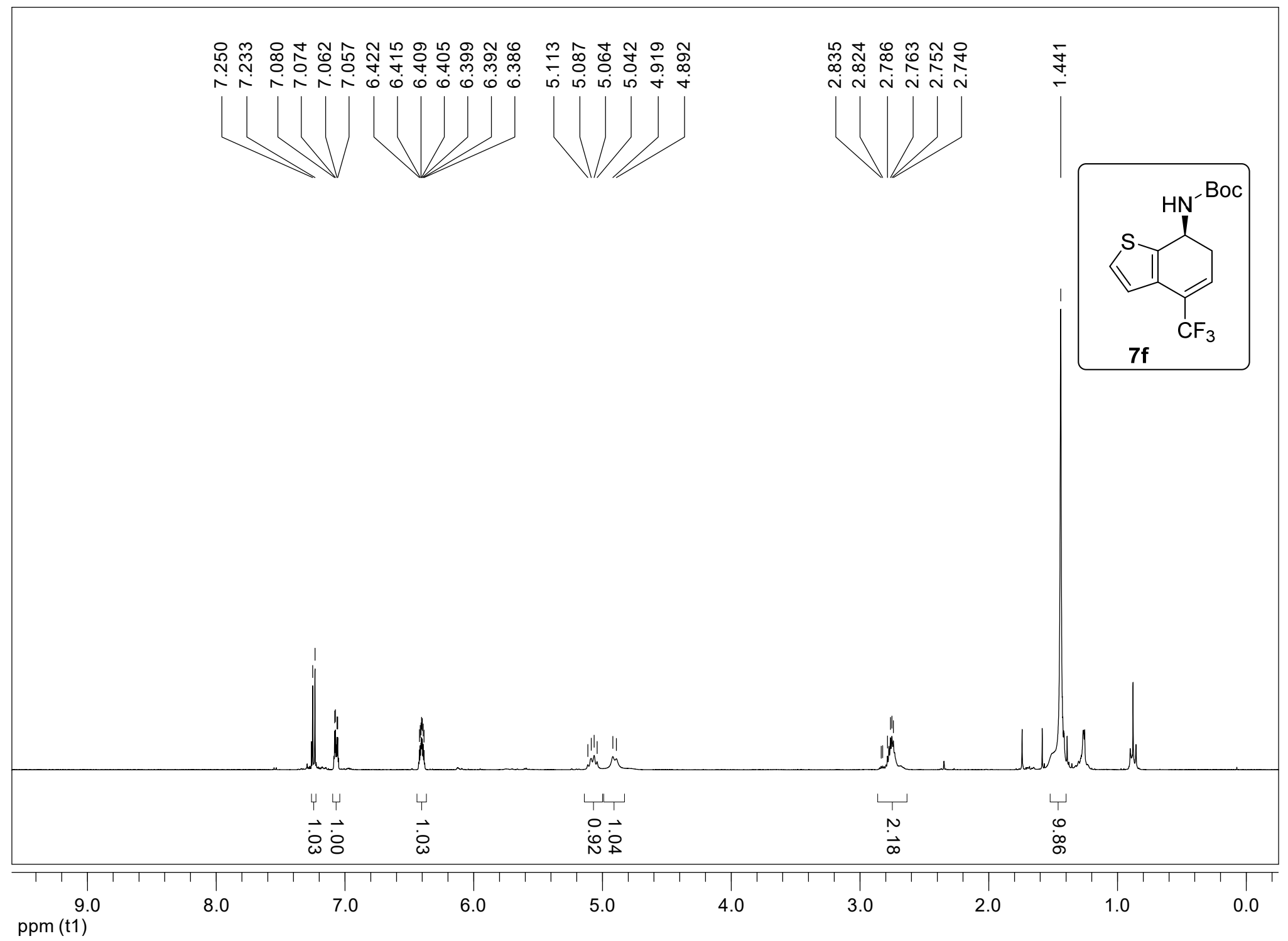




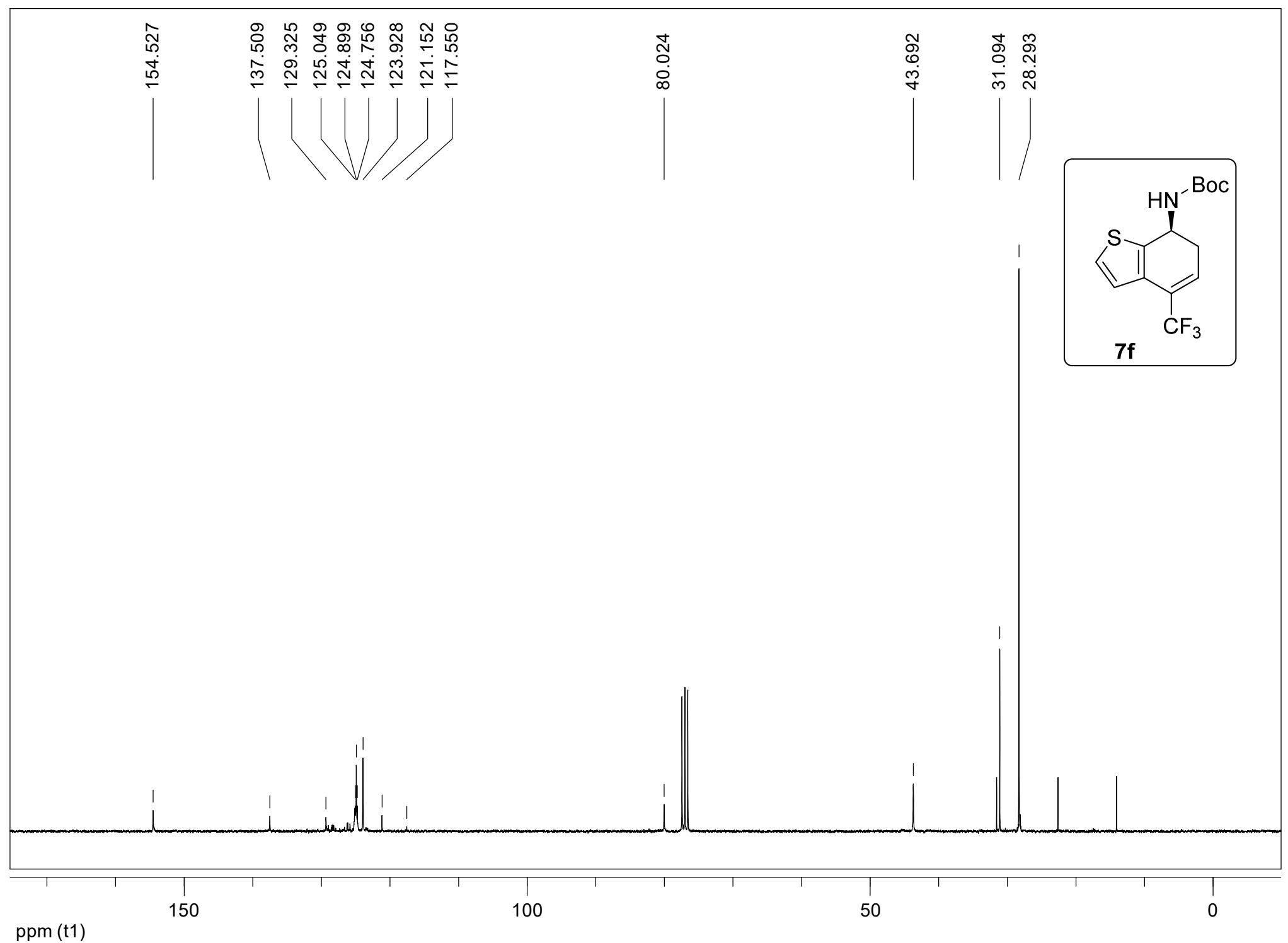




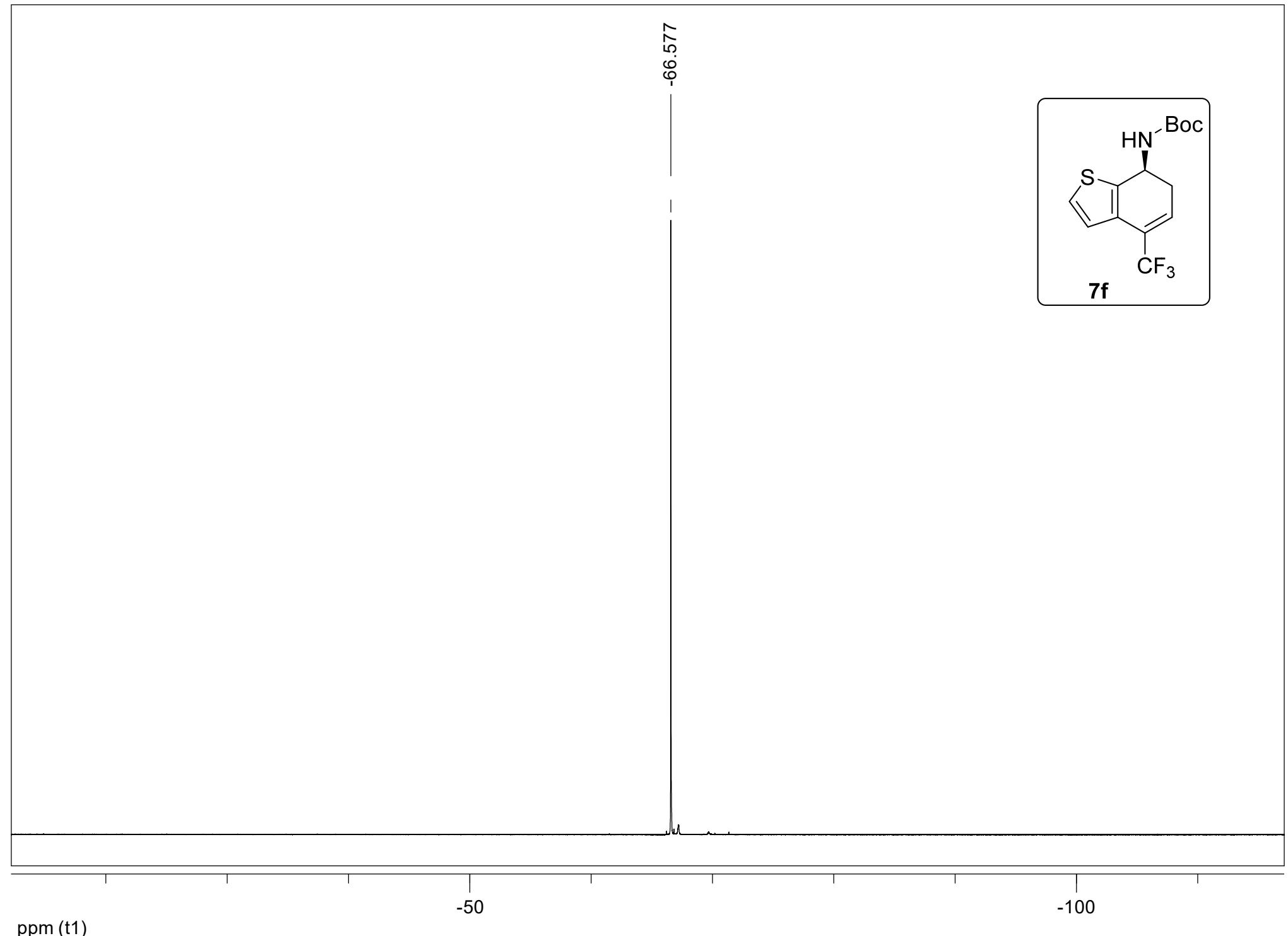

ppm (t1) 


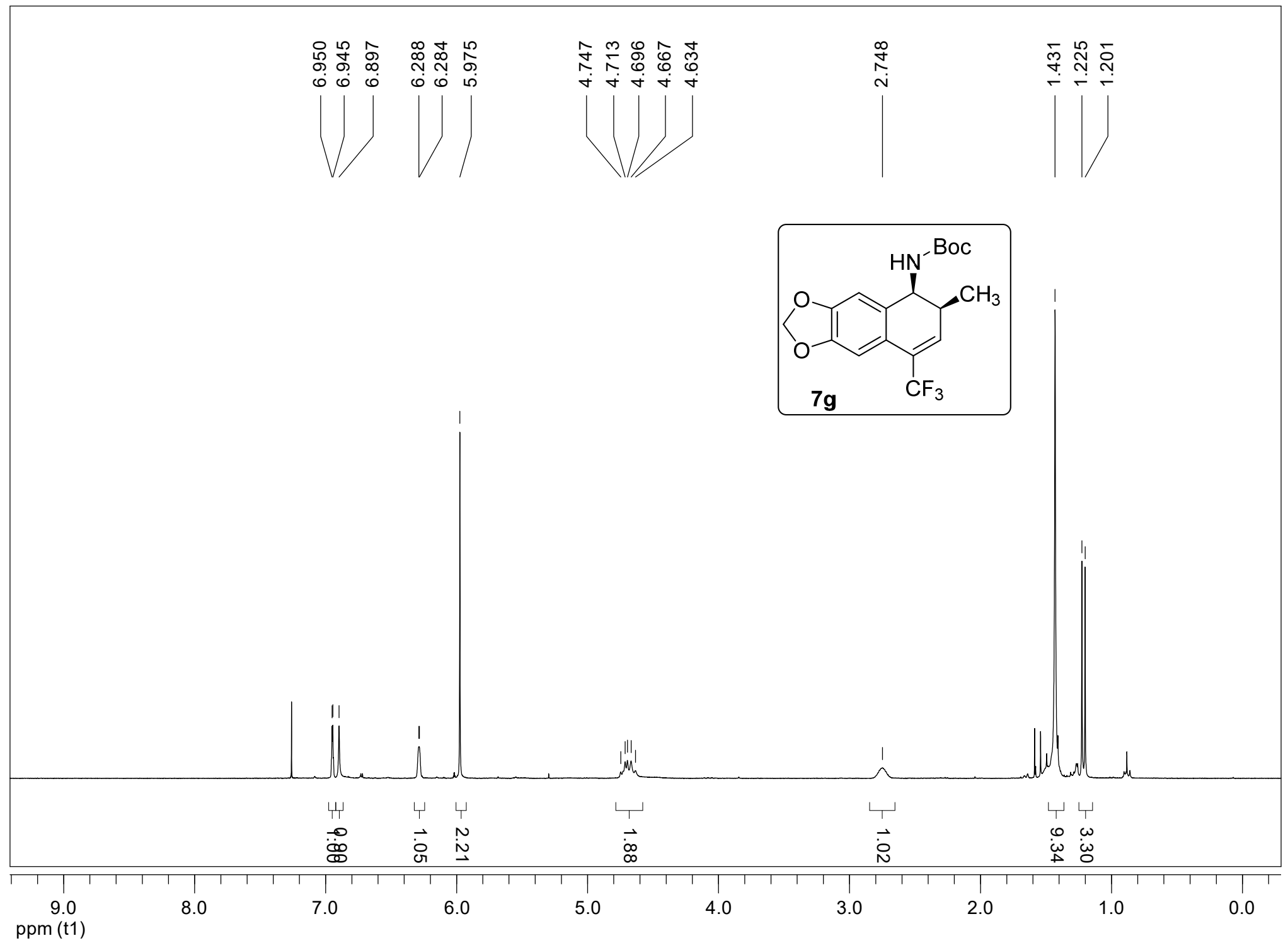




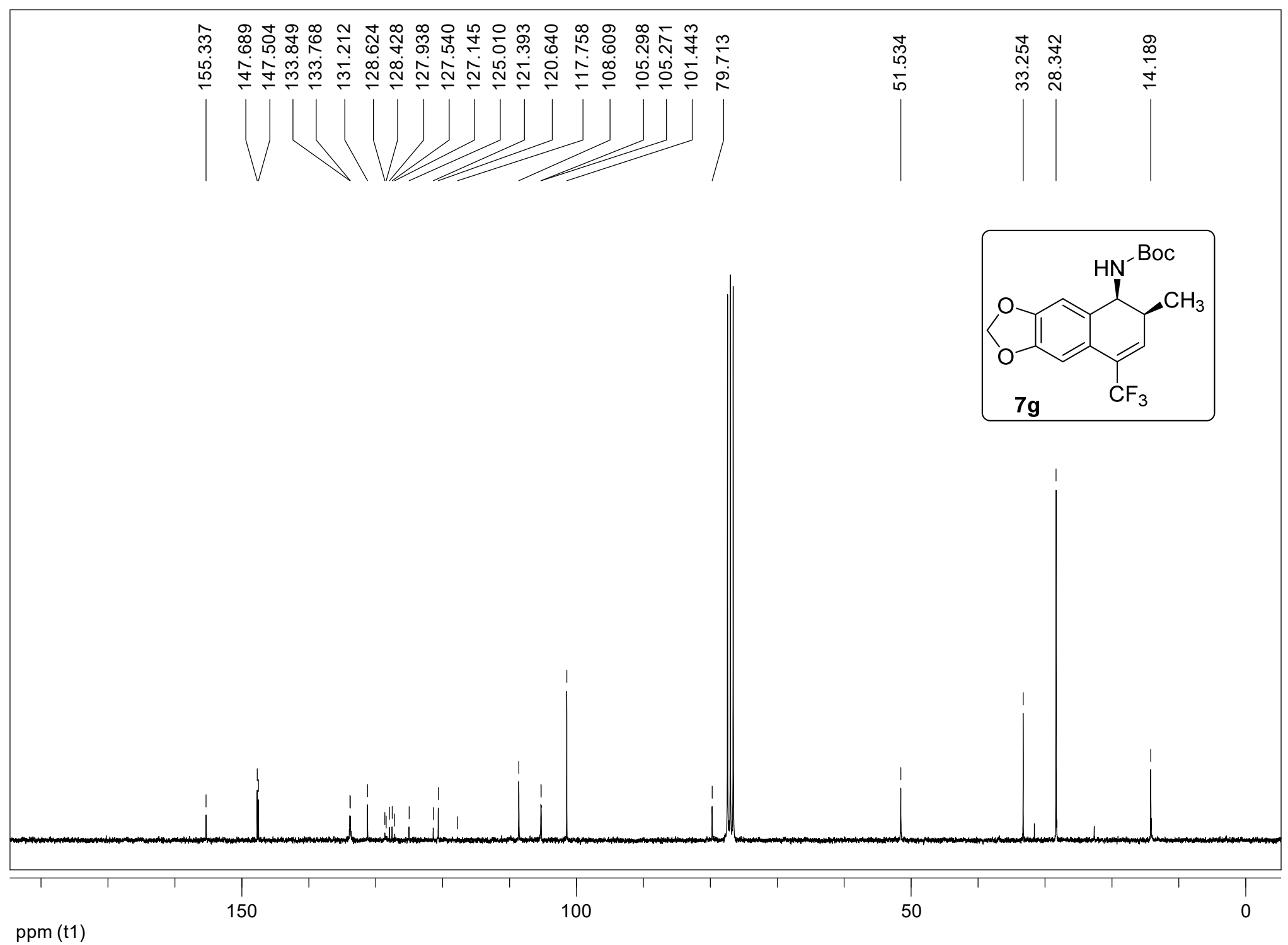




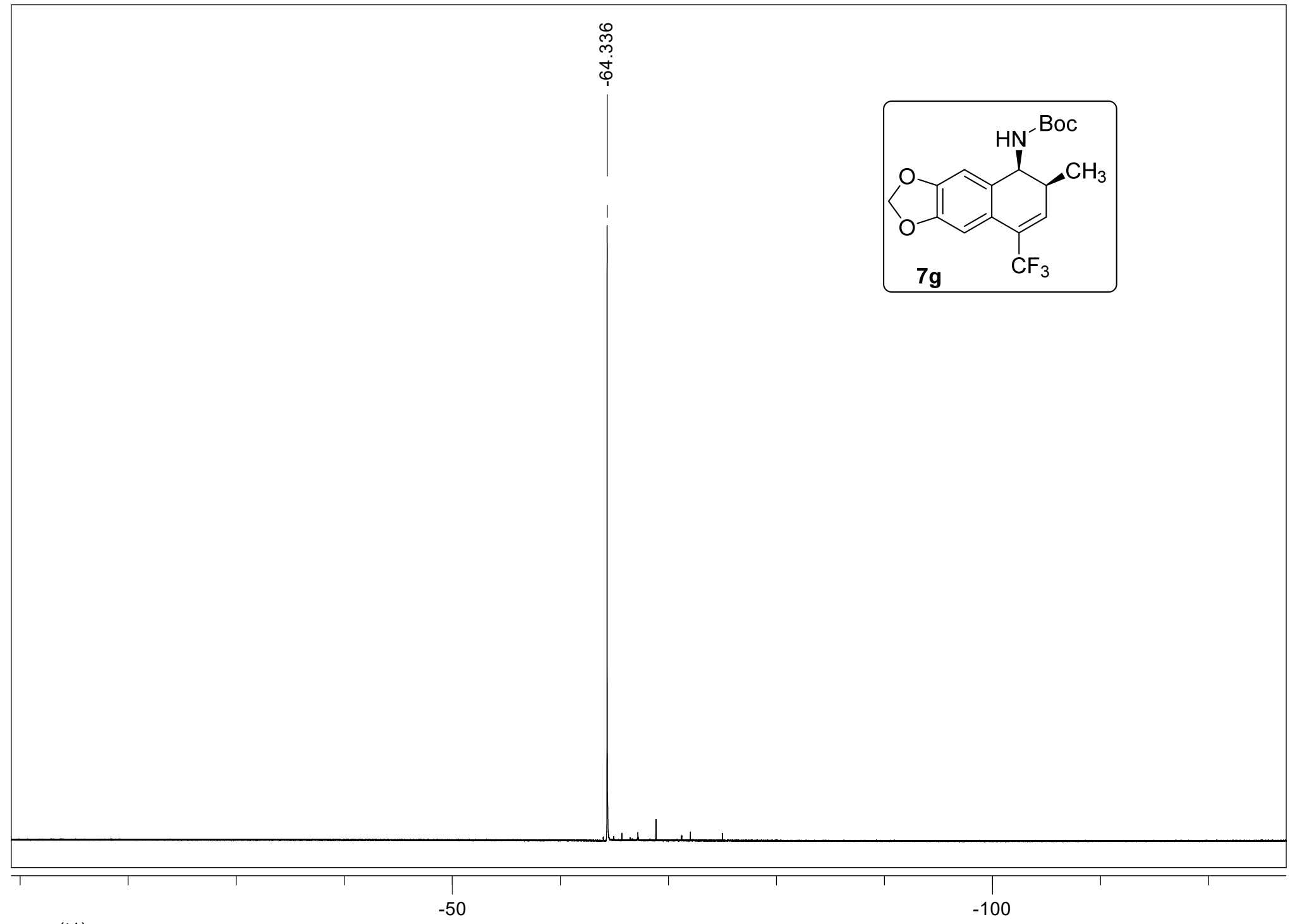

ppm (t1) 


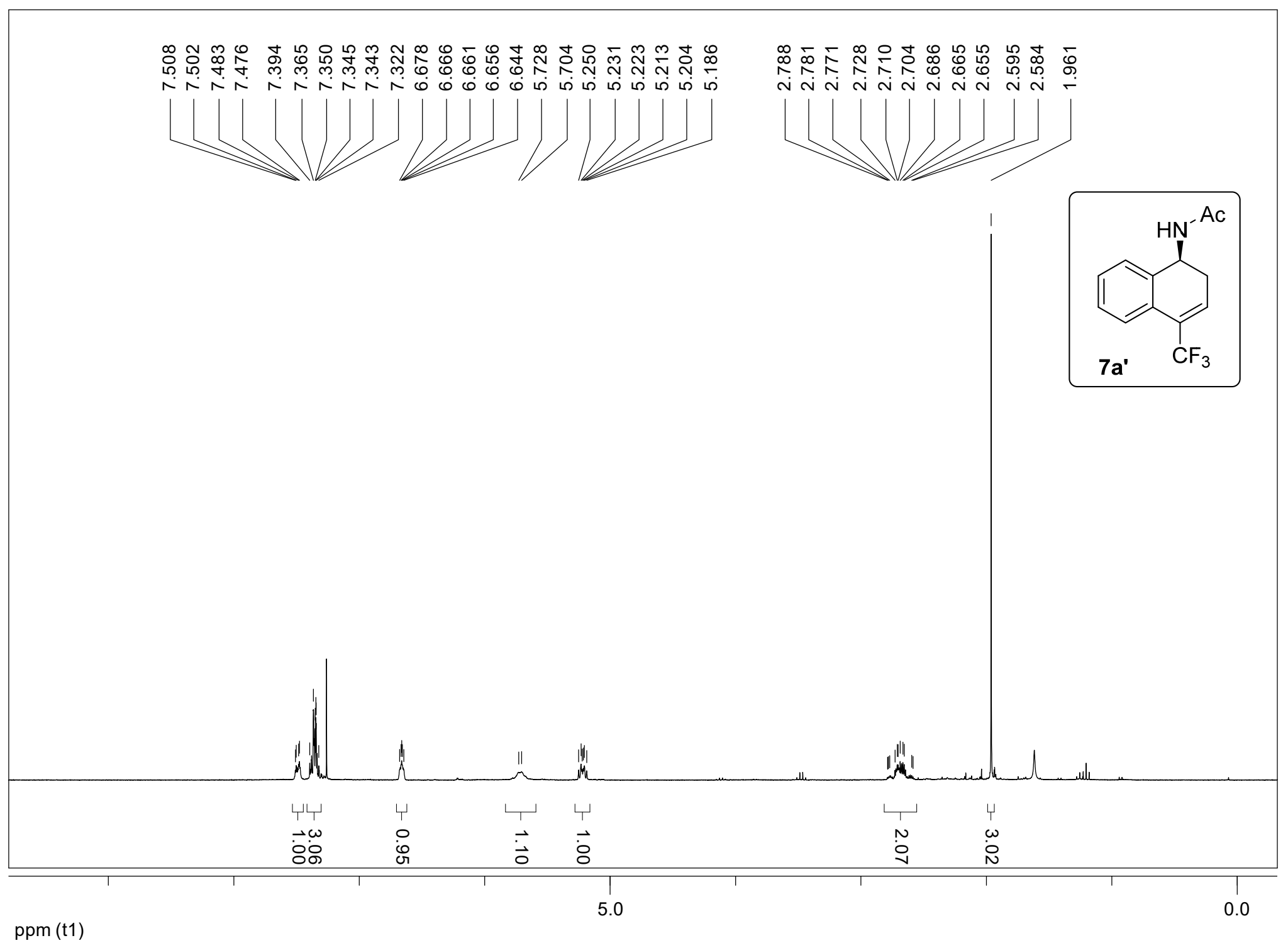




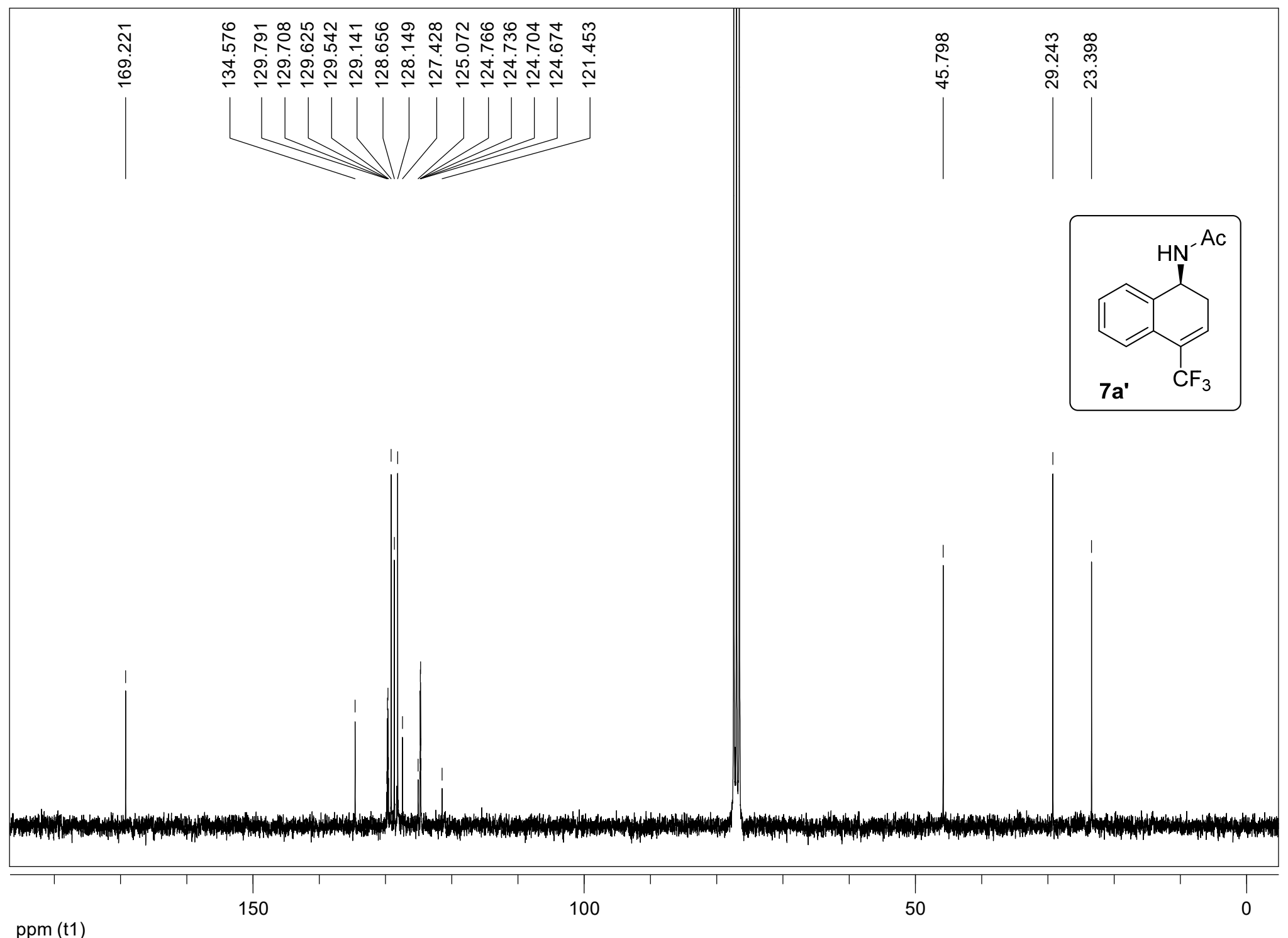




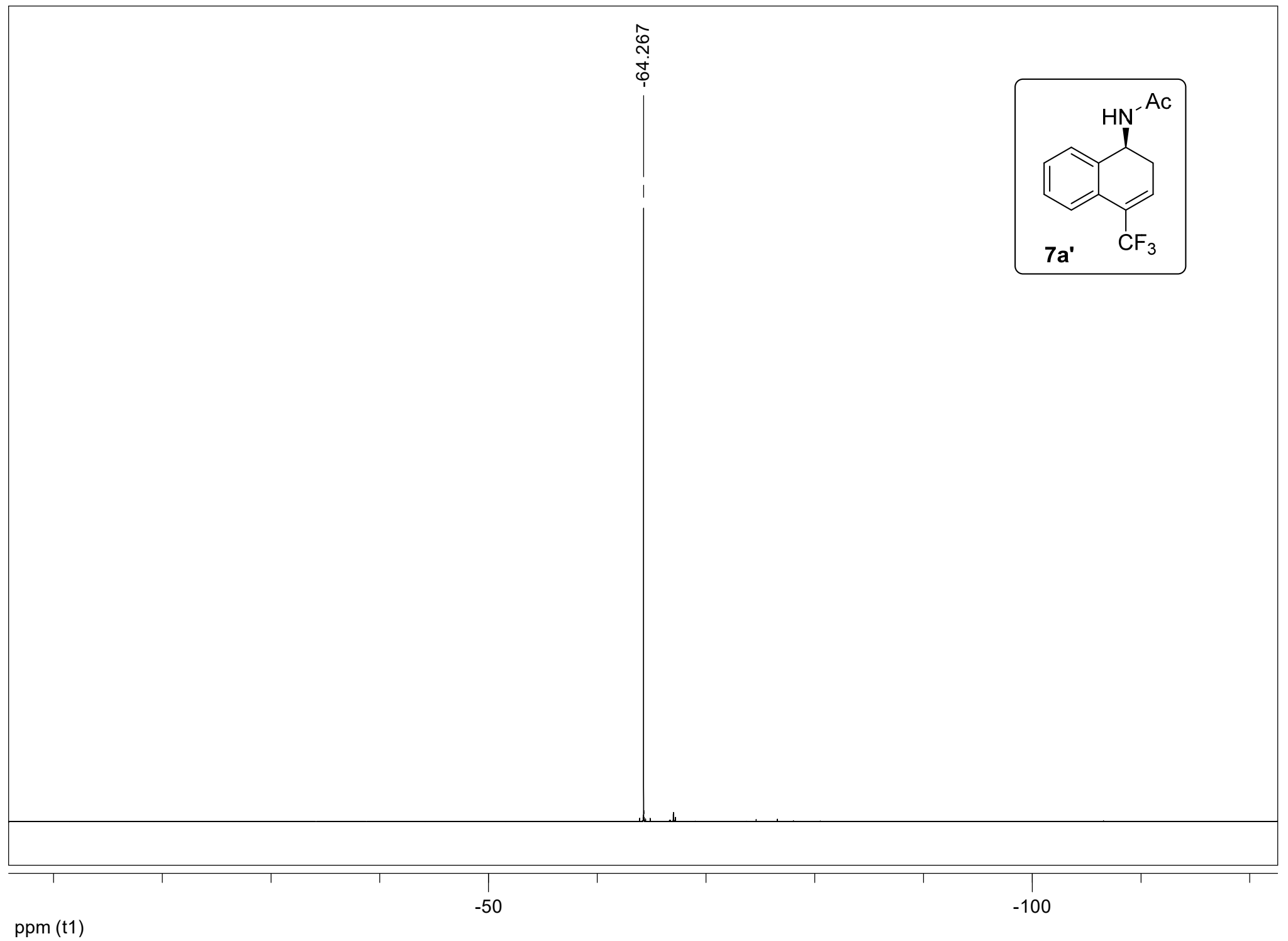




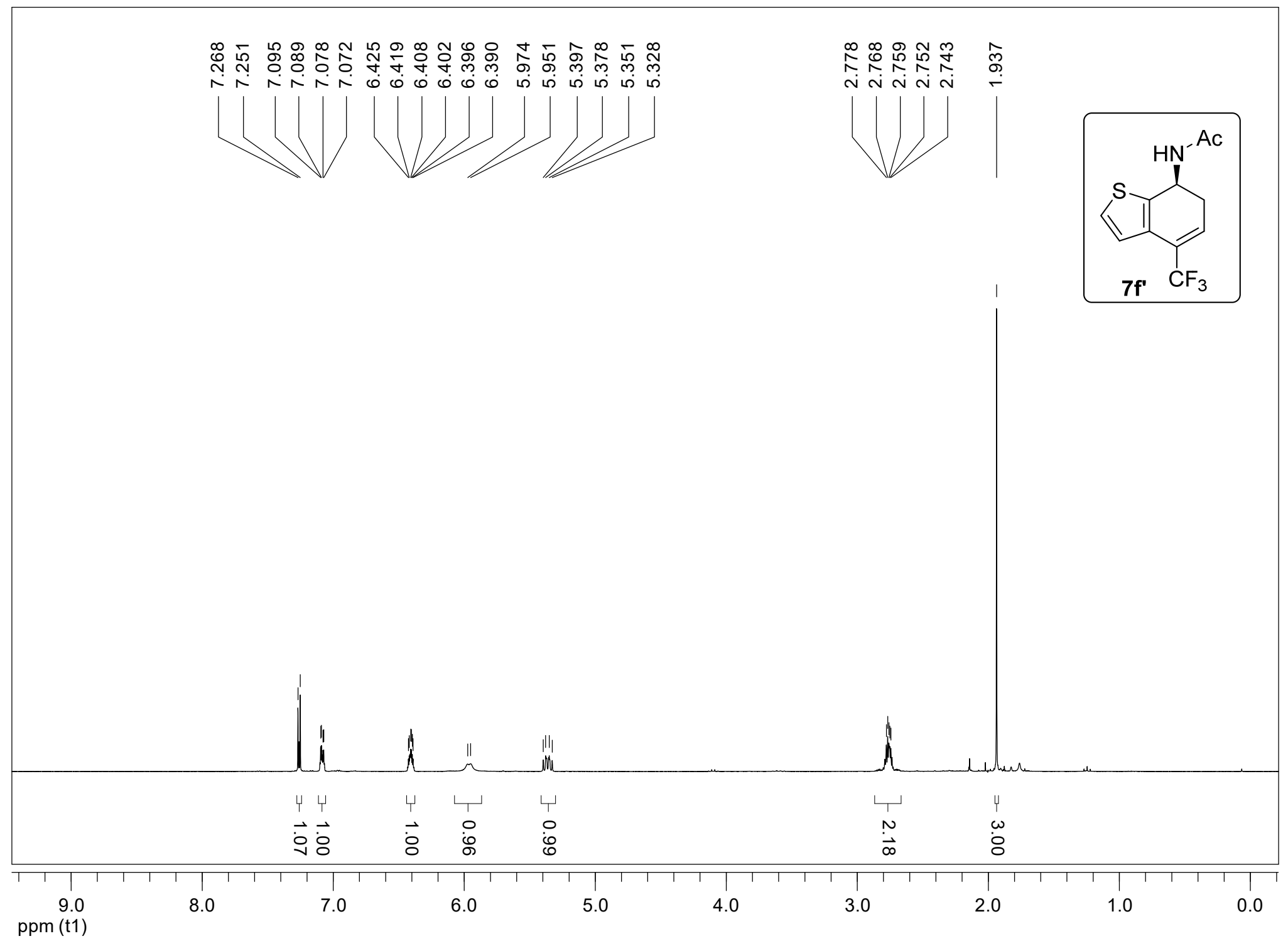




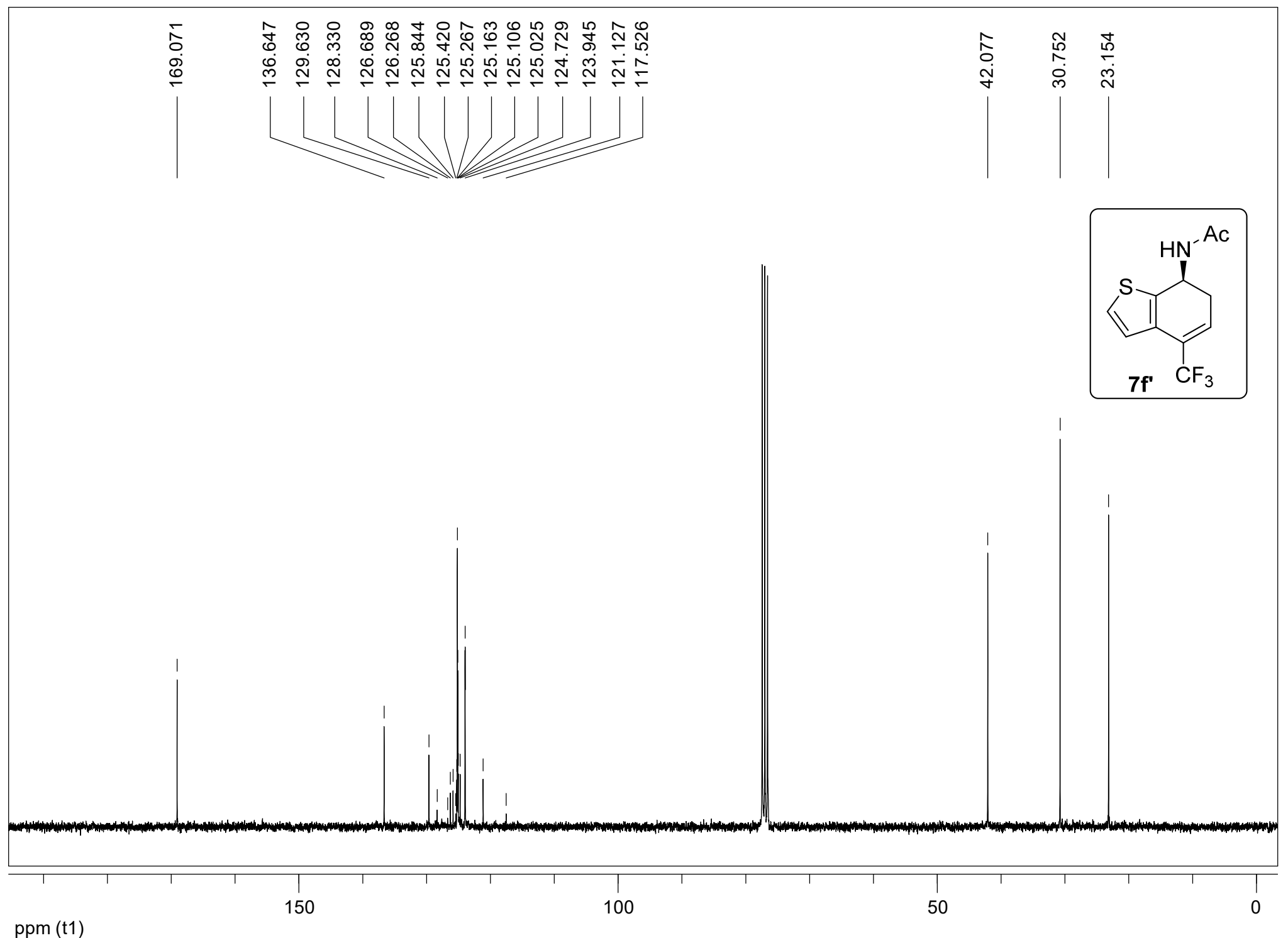




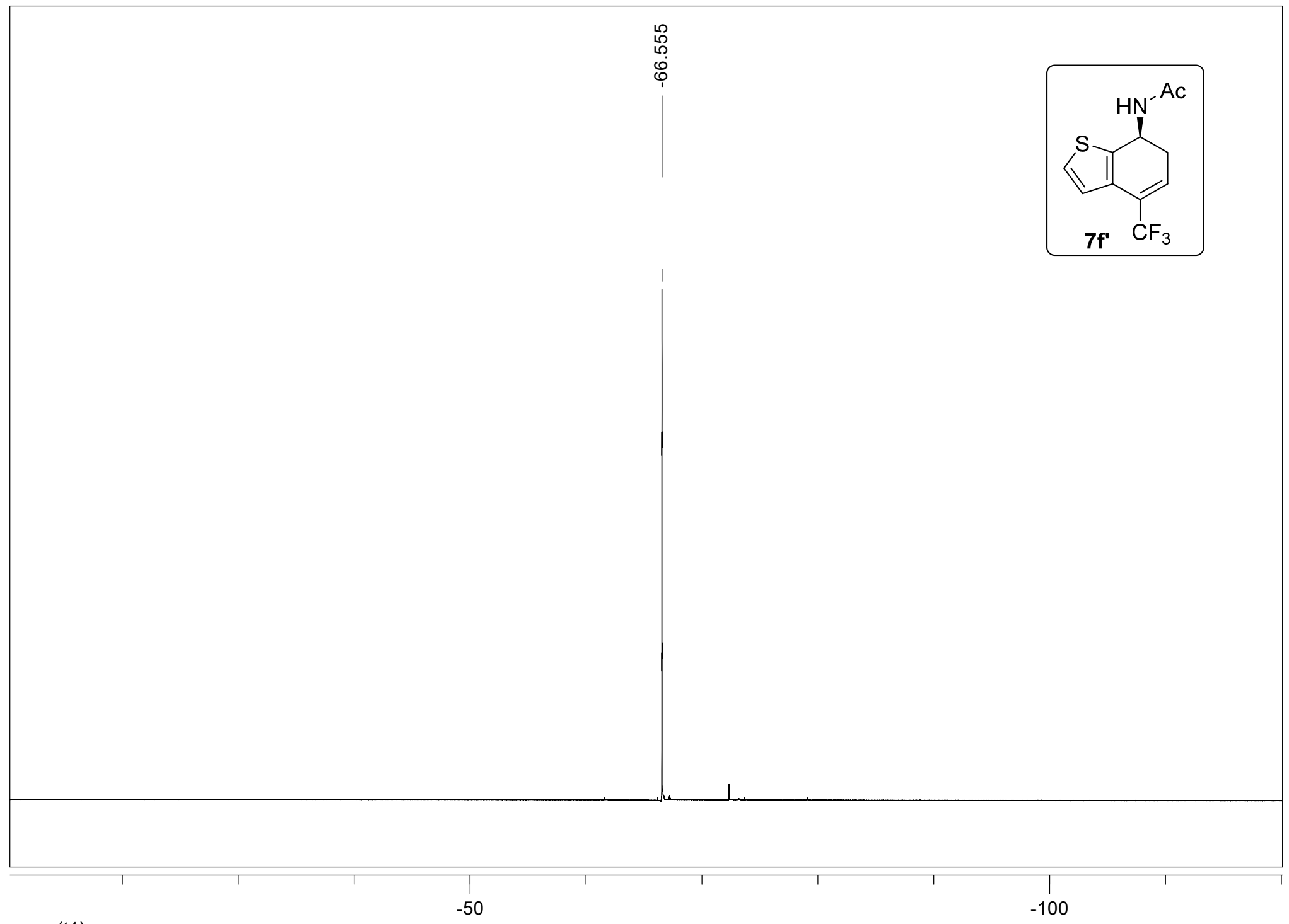

ppm (t1) 


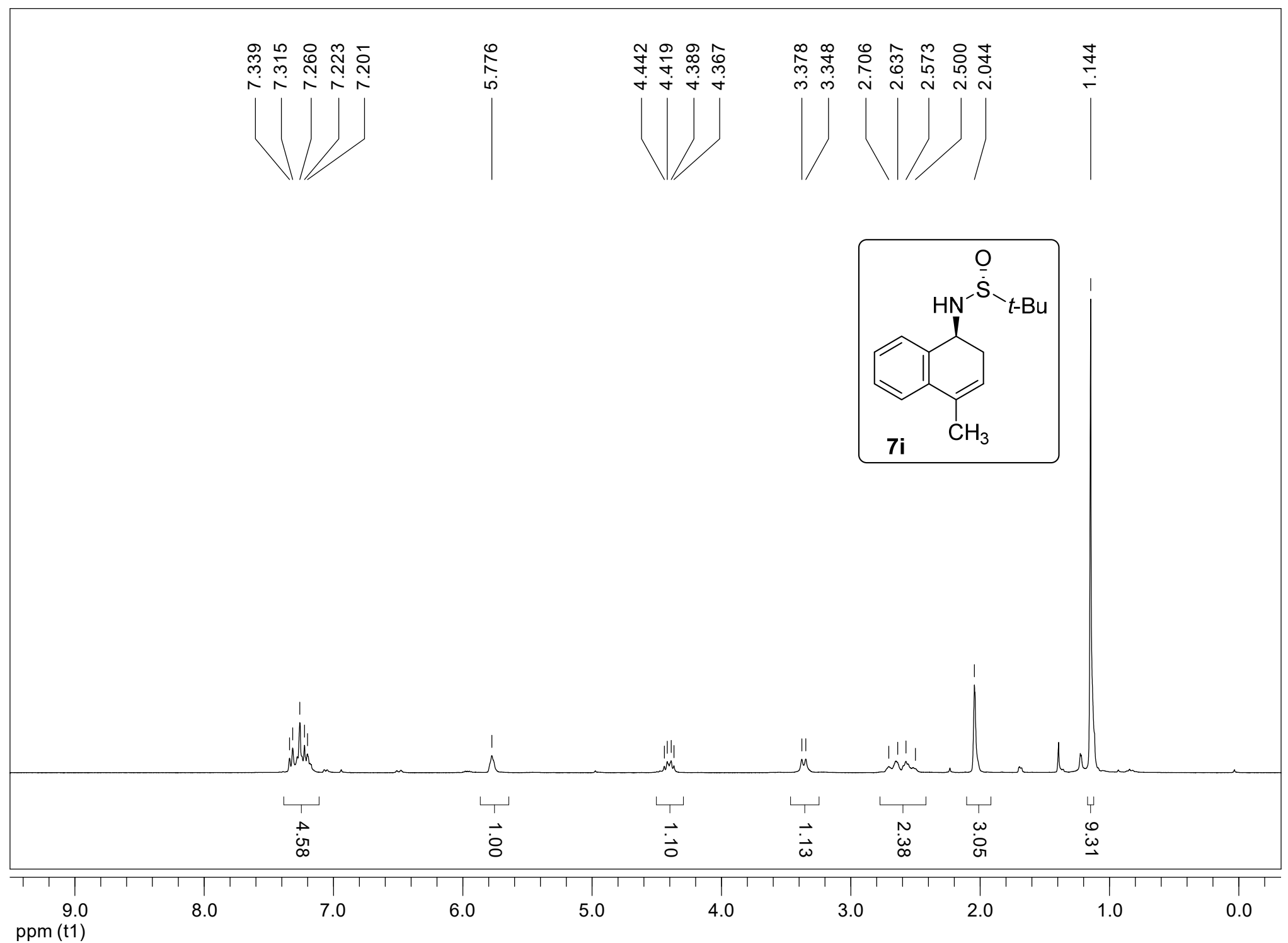




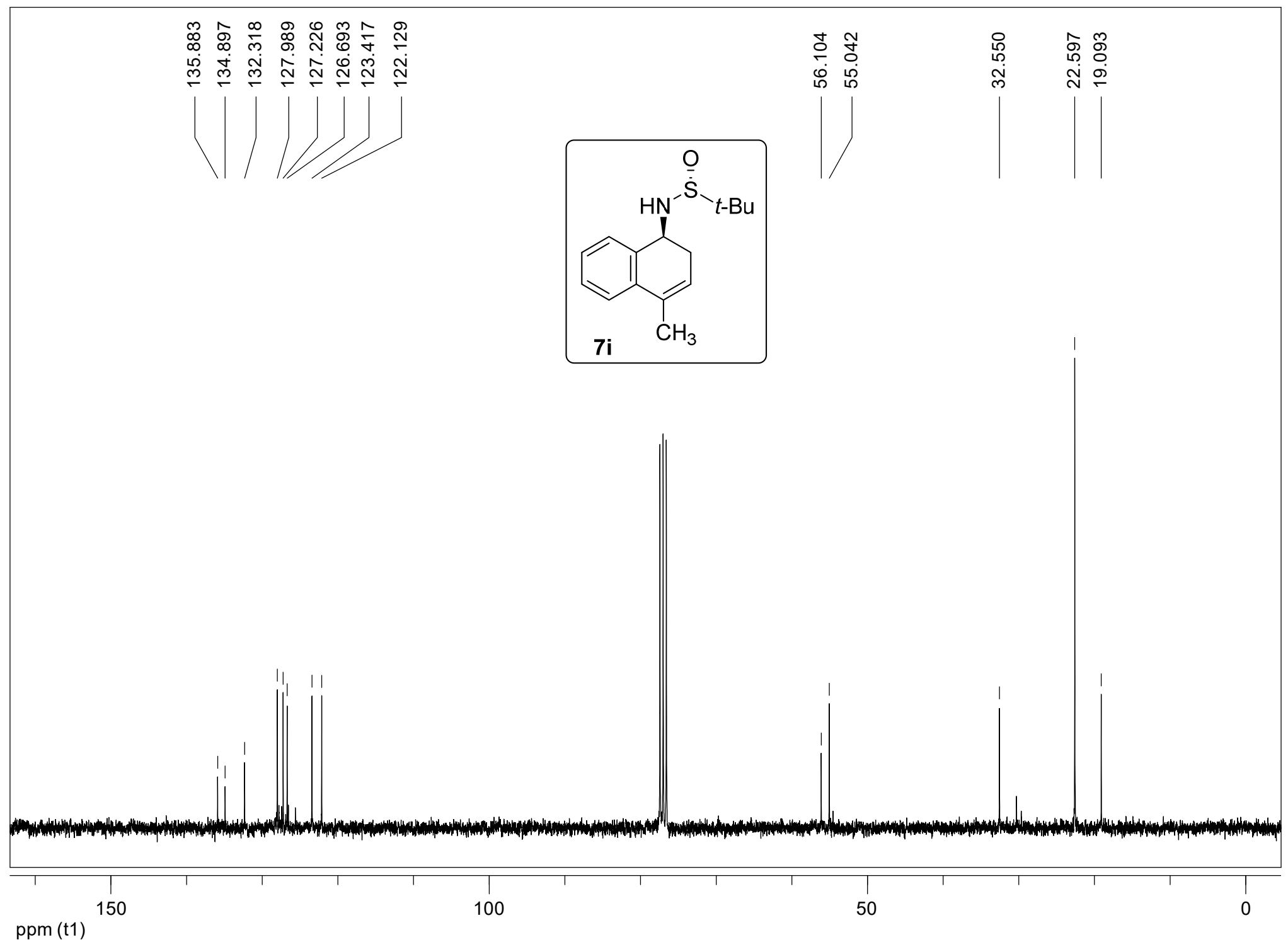




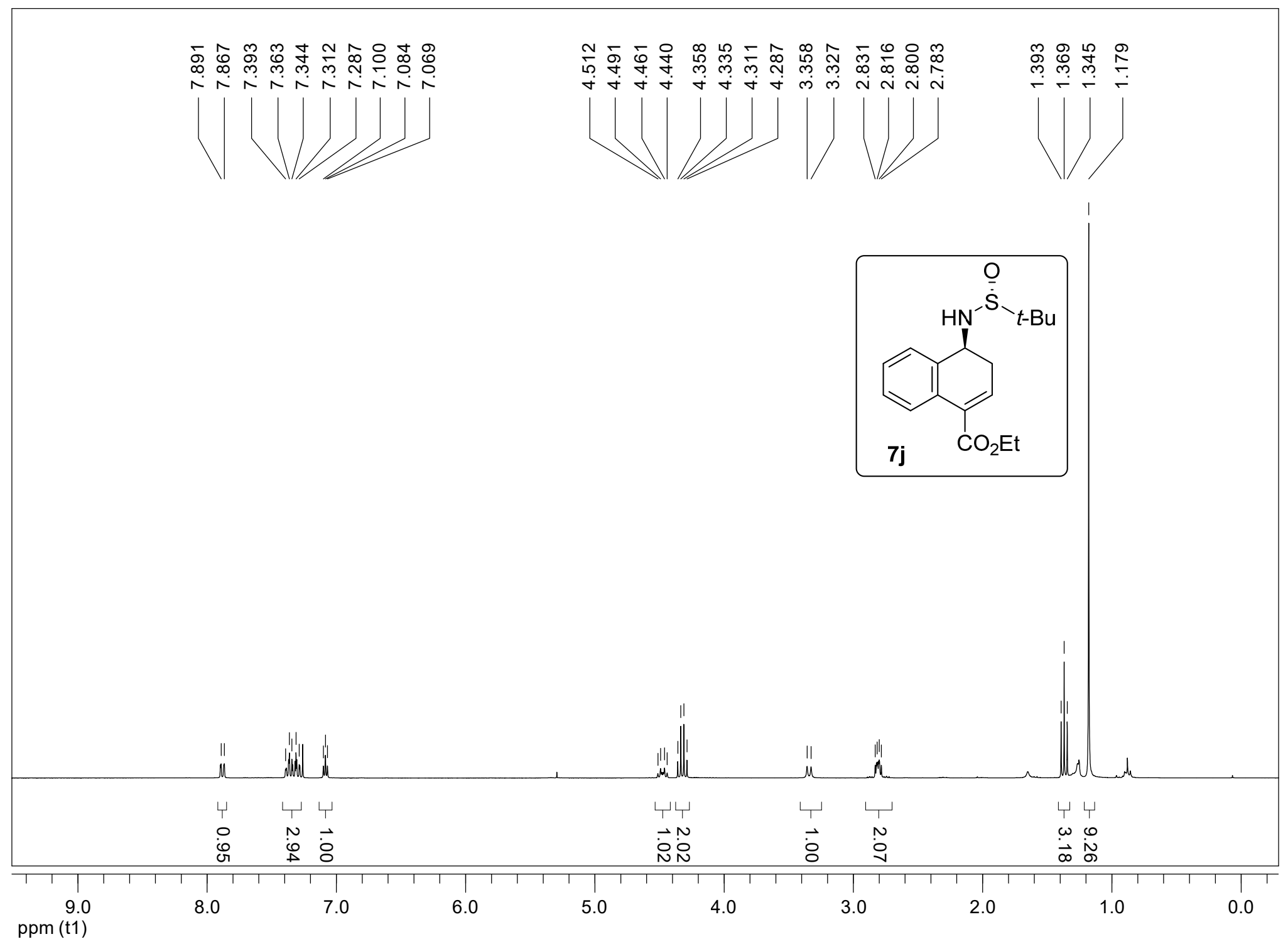




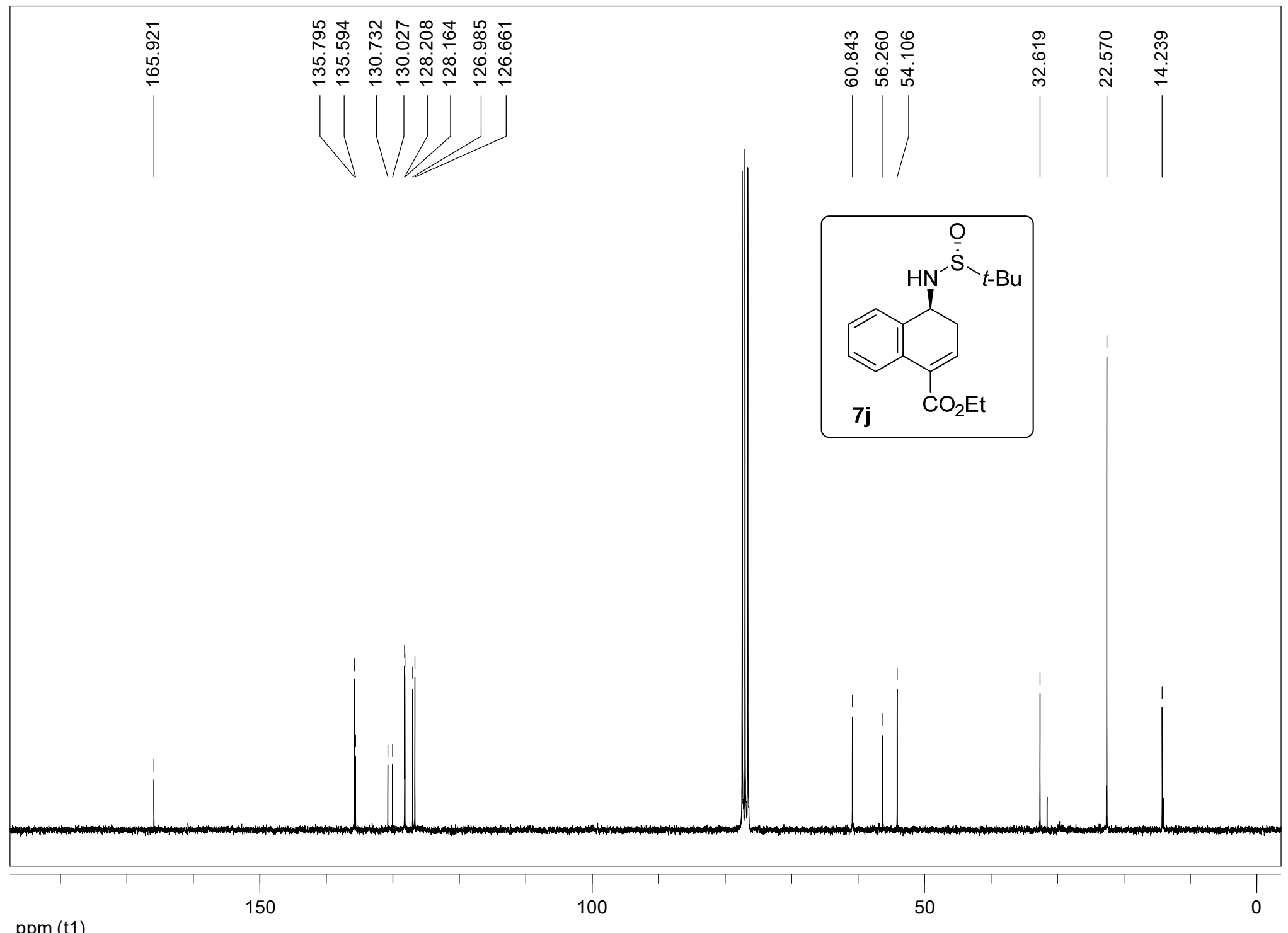

ppm (t1) 


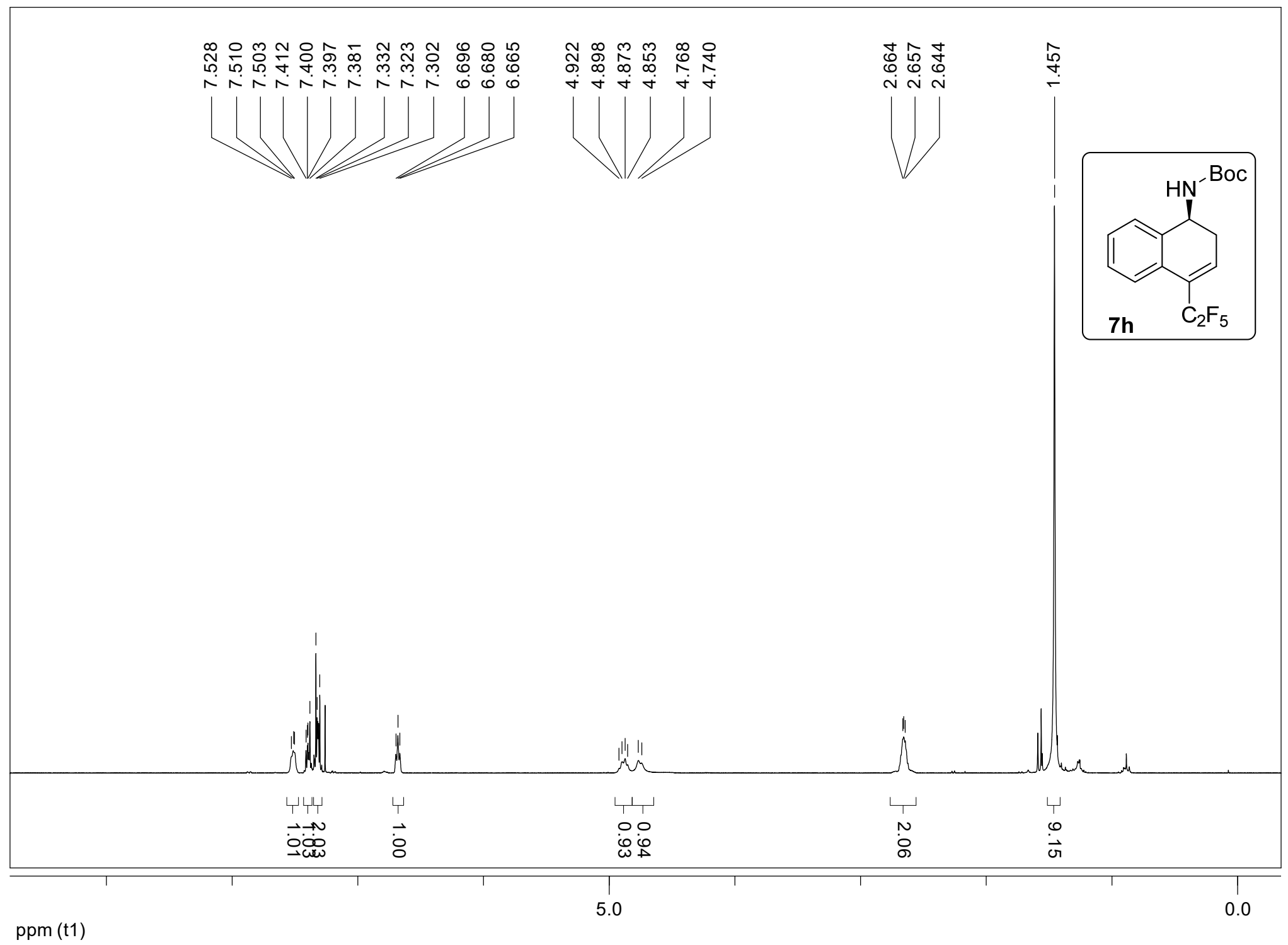




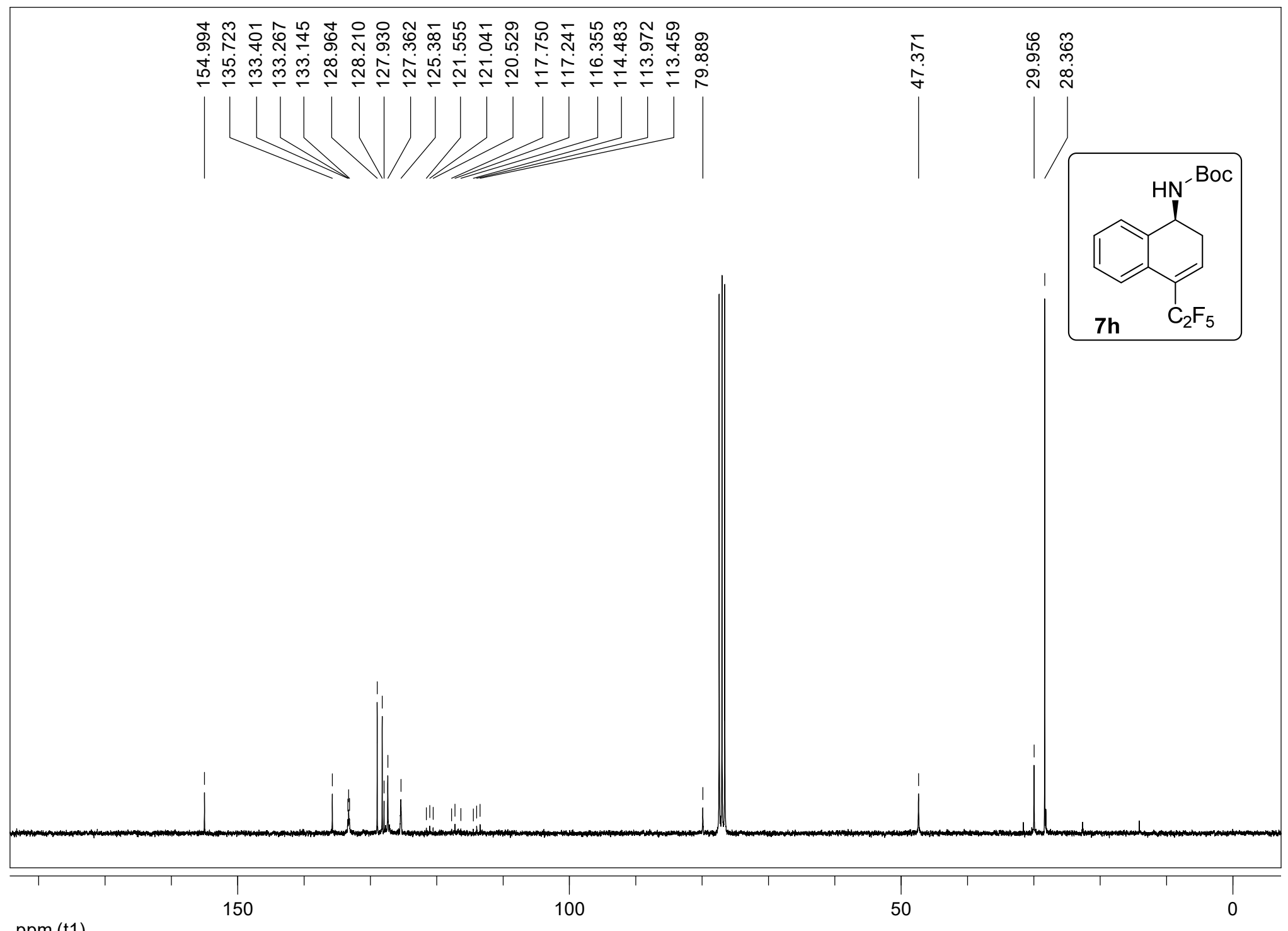

ppm (t1) 


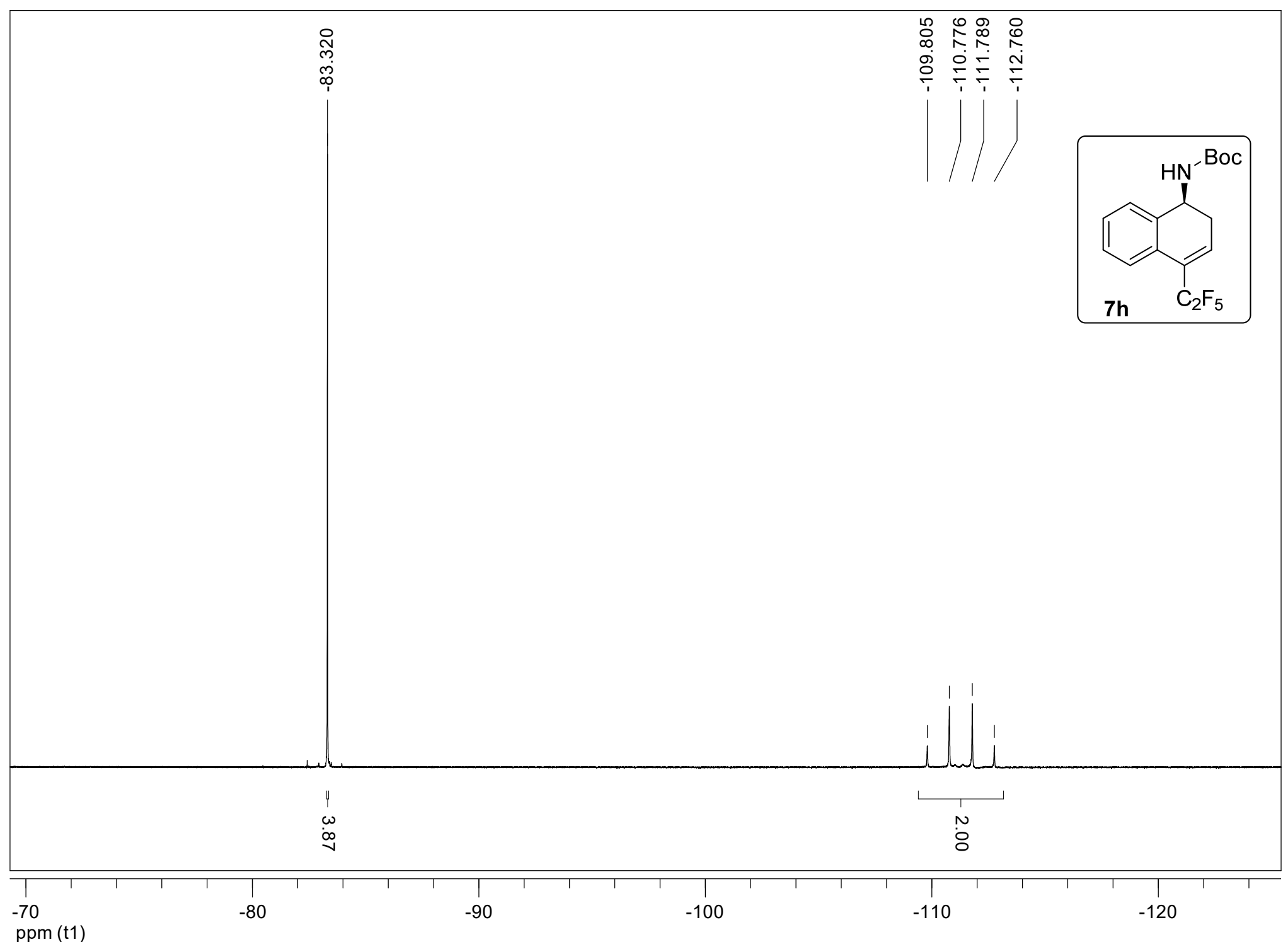




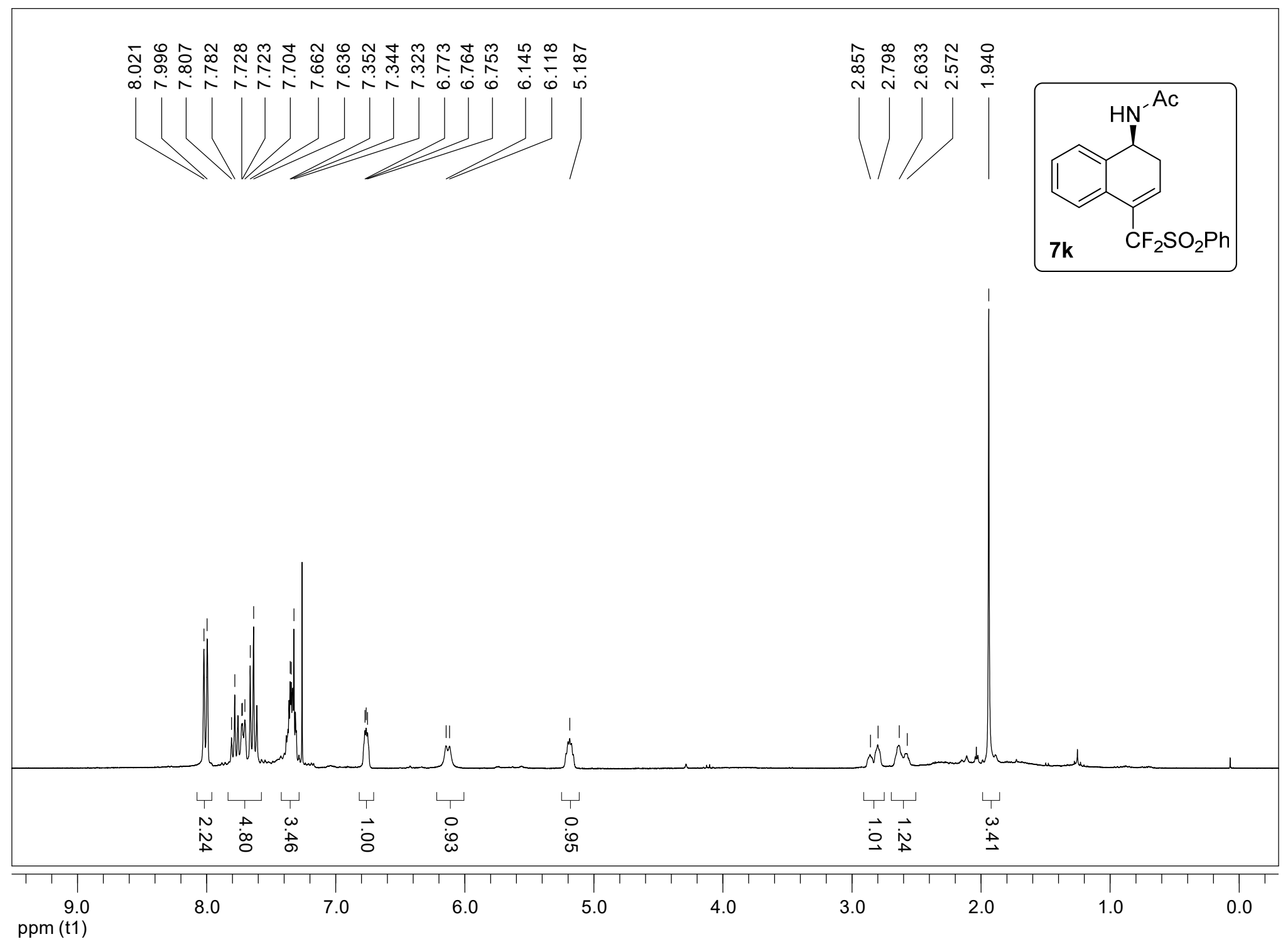




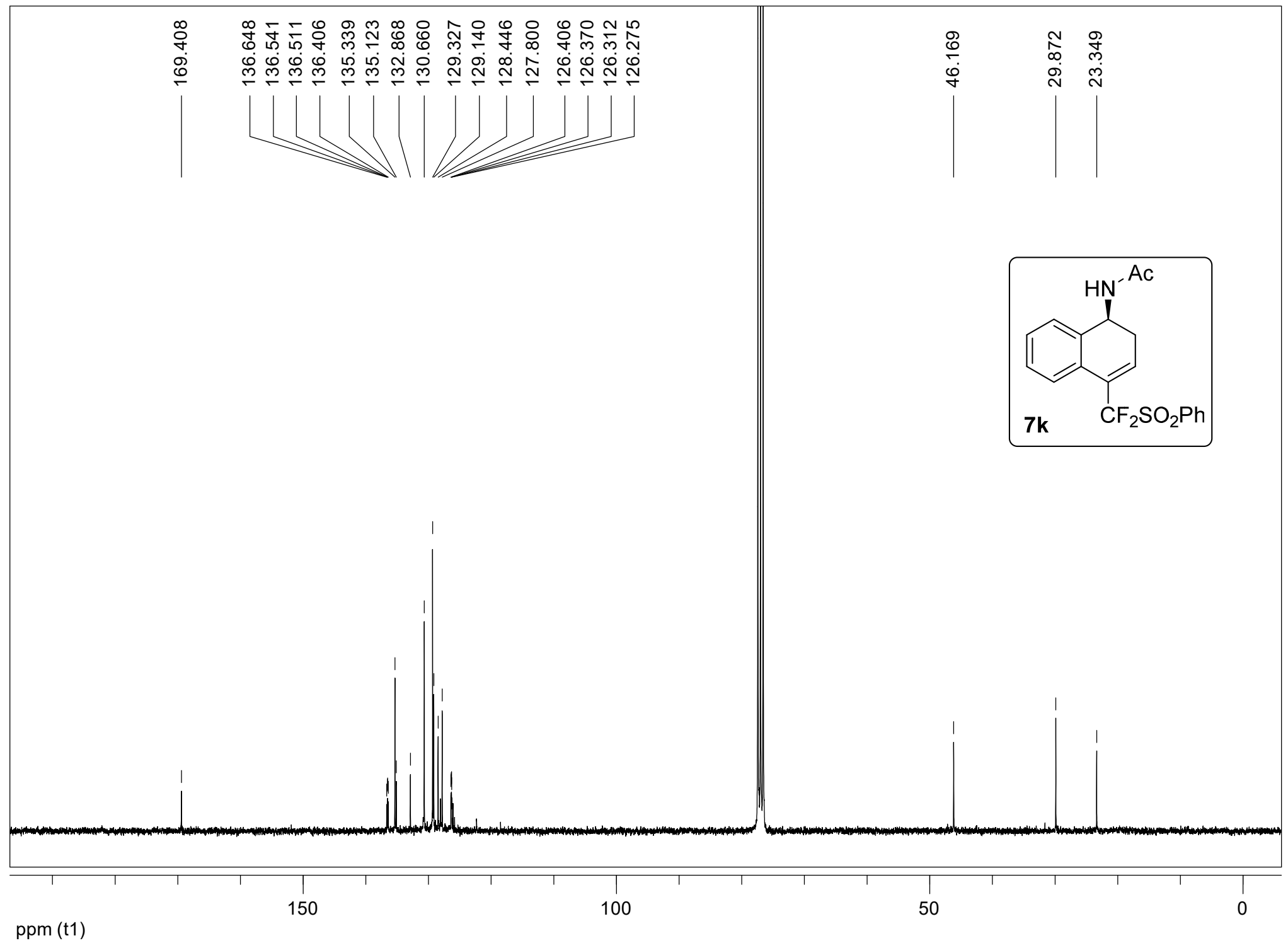




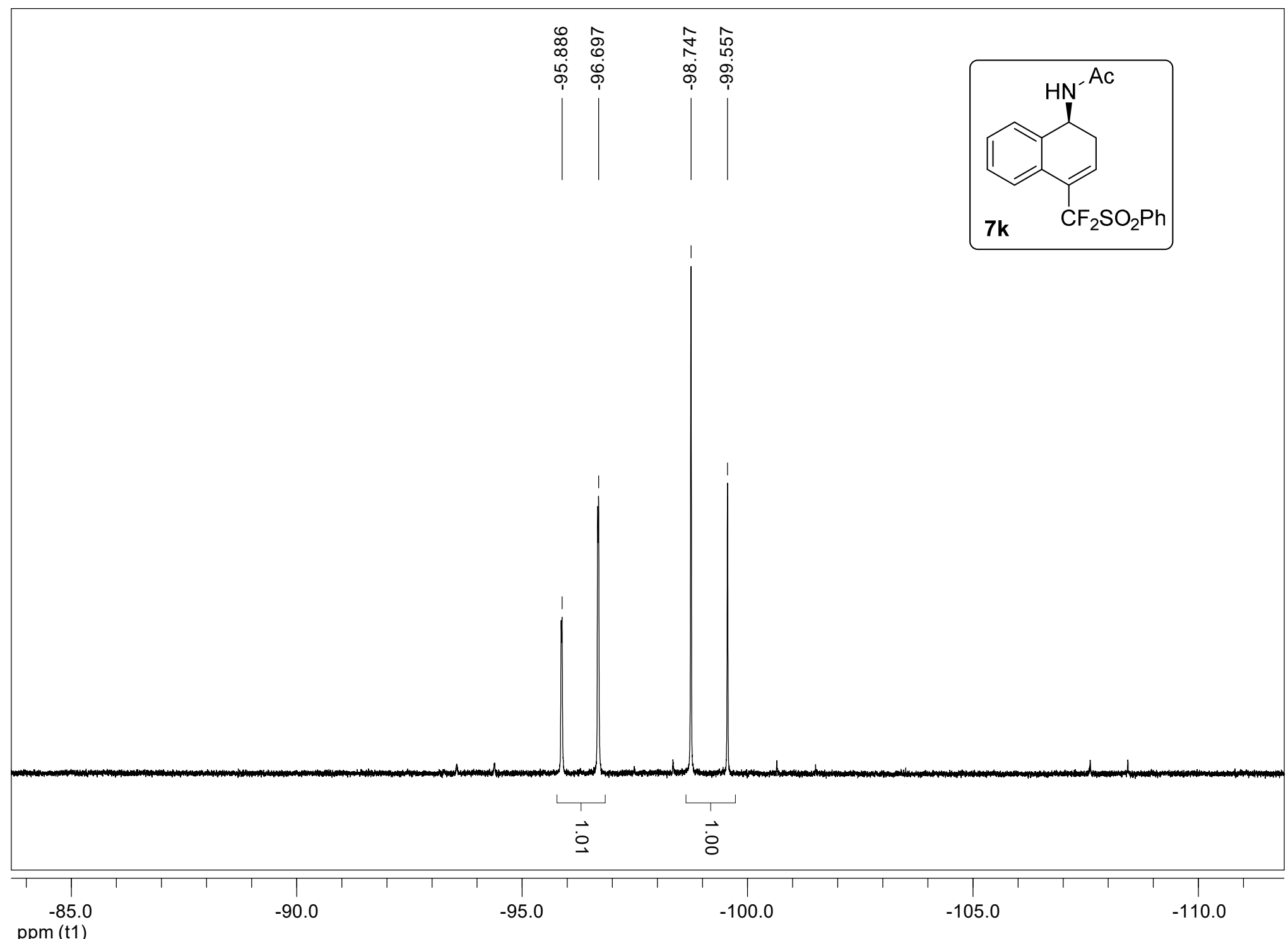




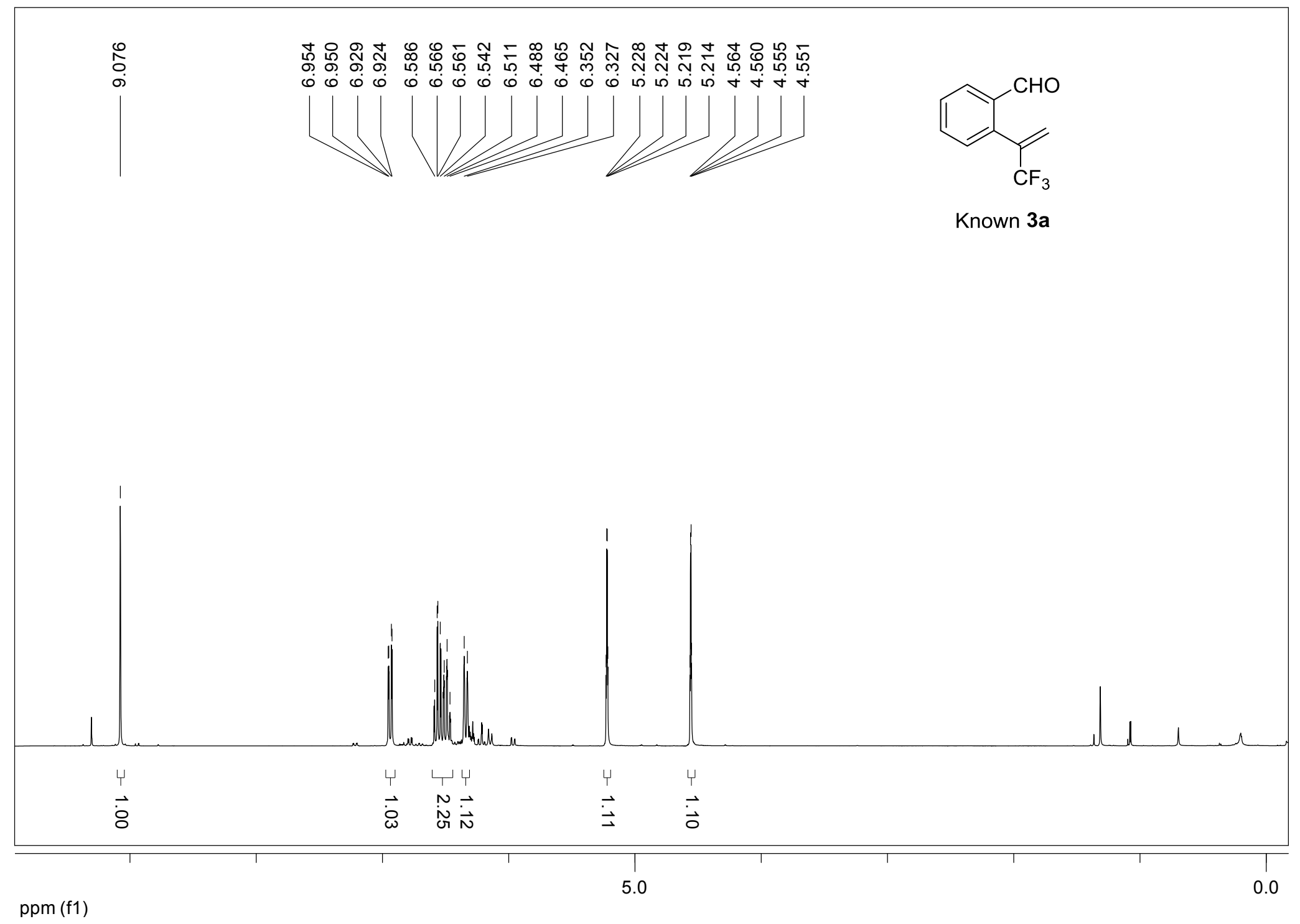




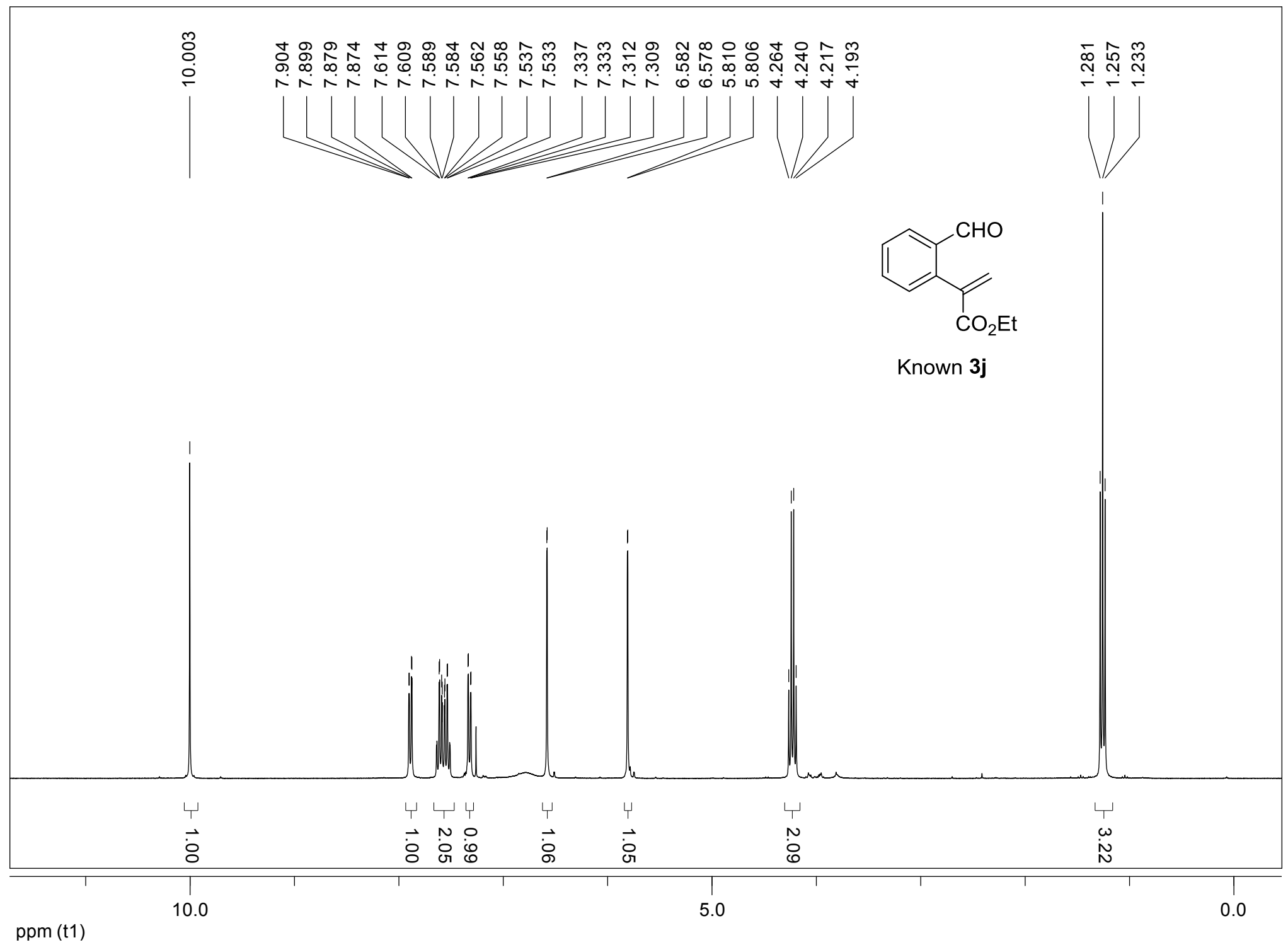




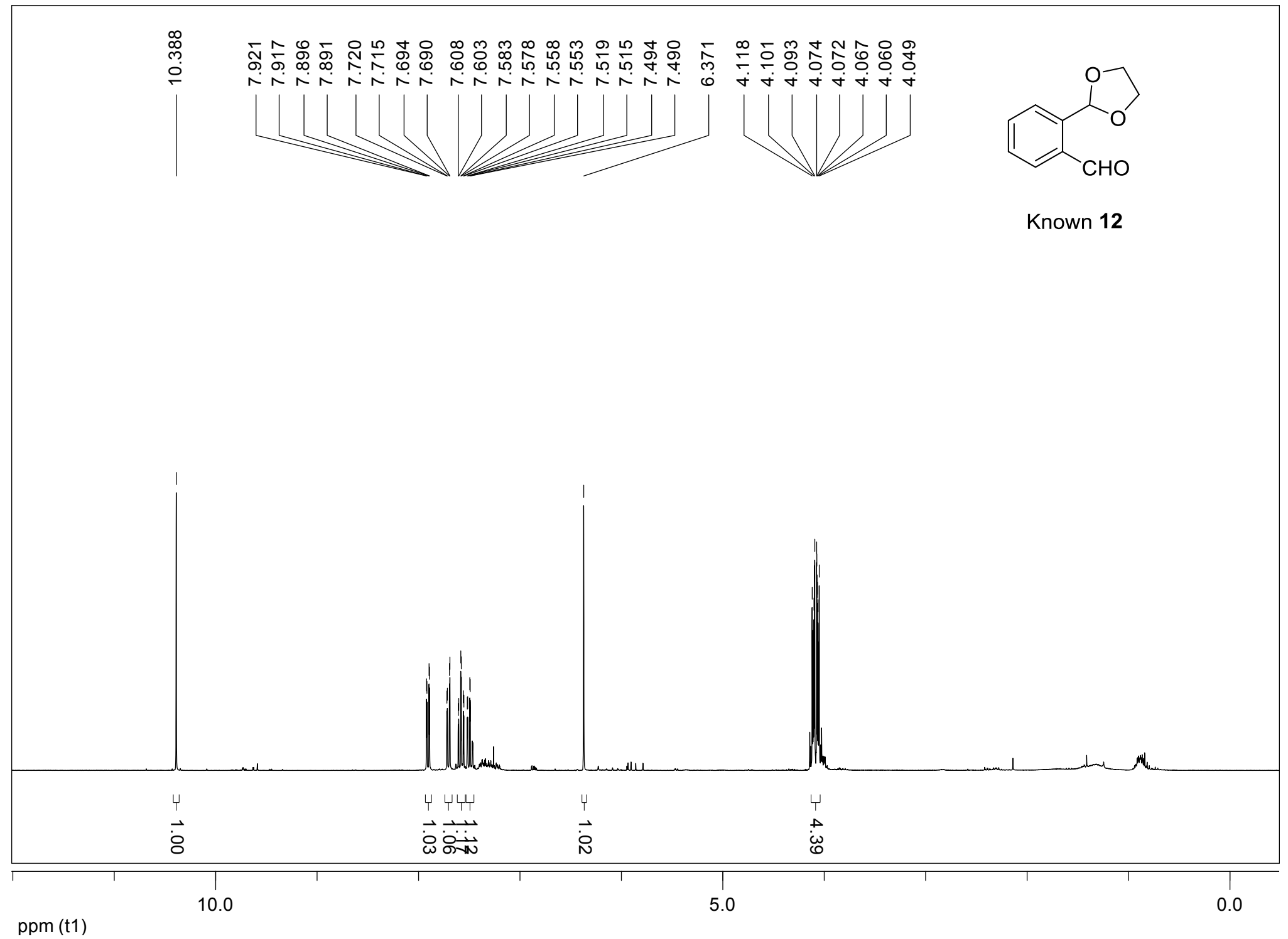




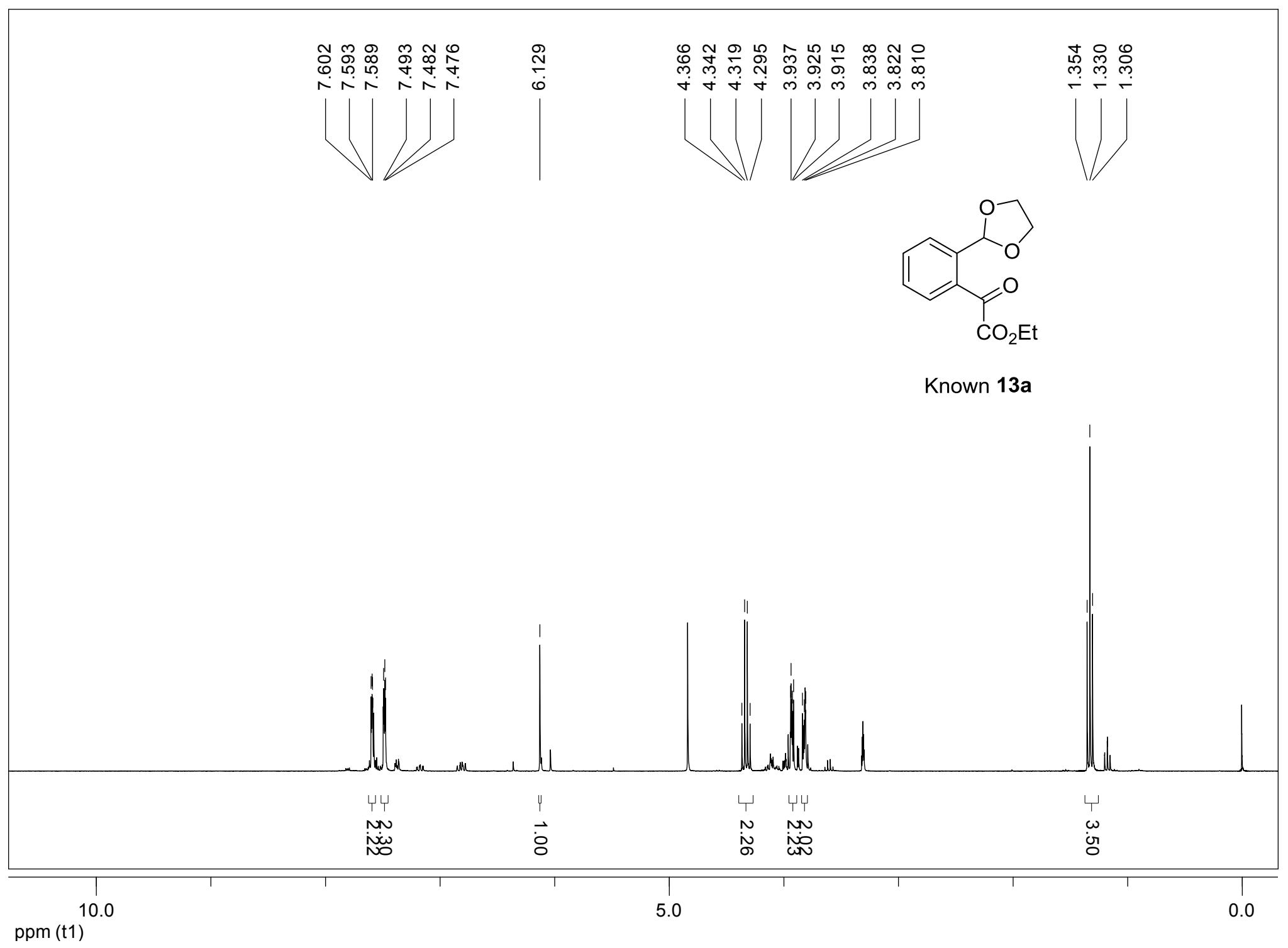



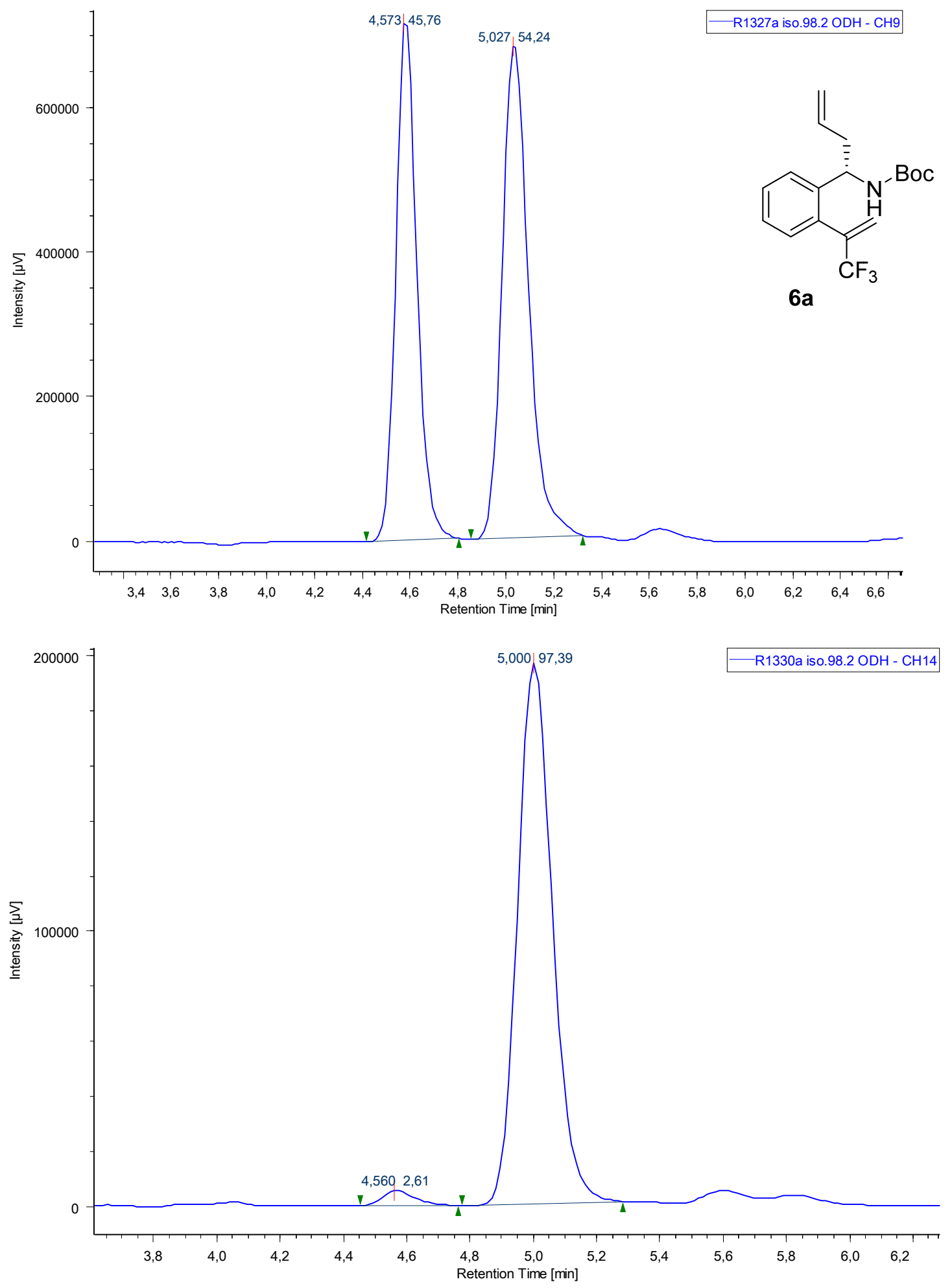

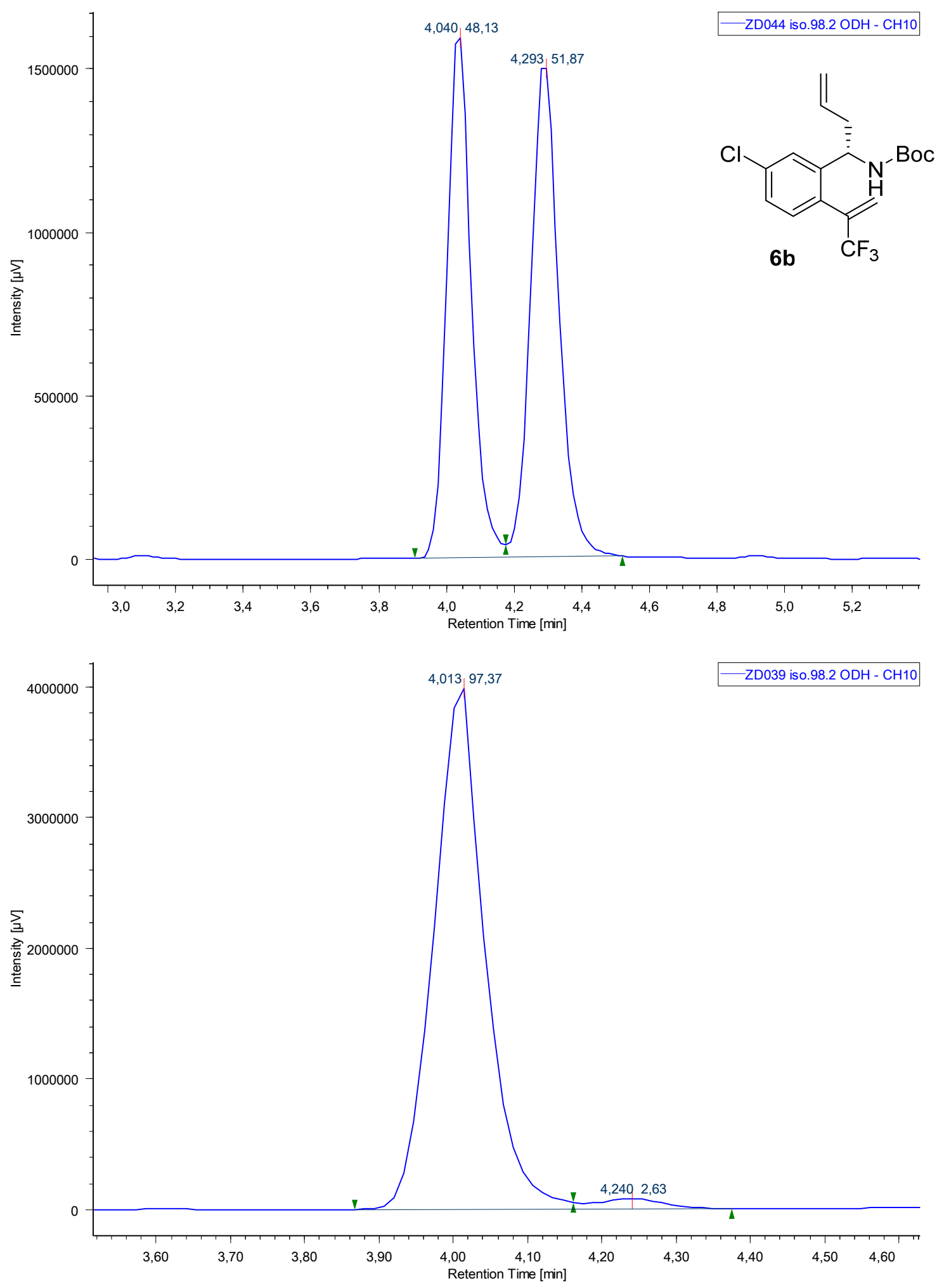

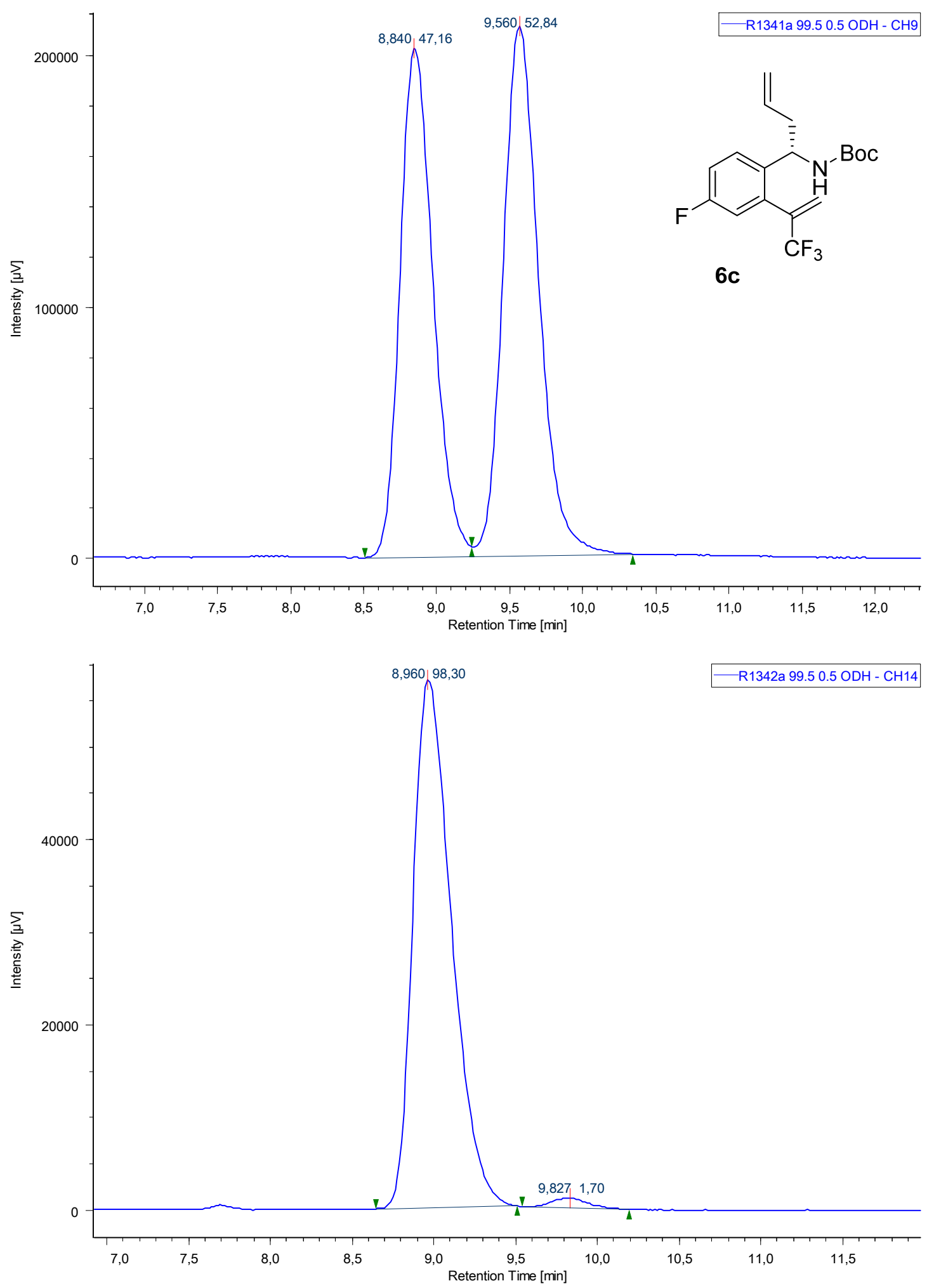

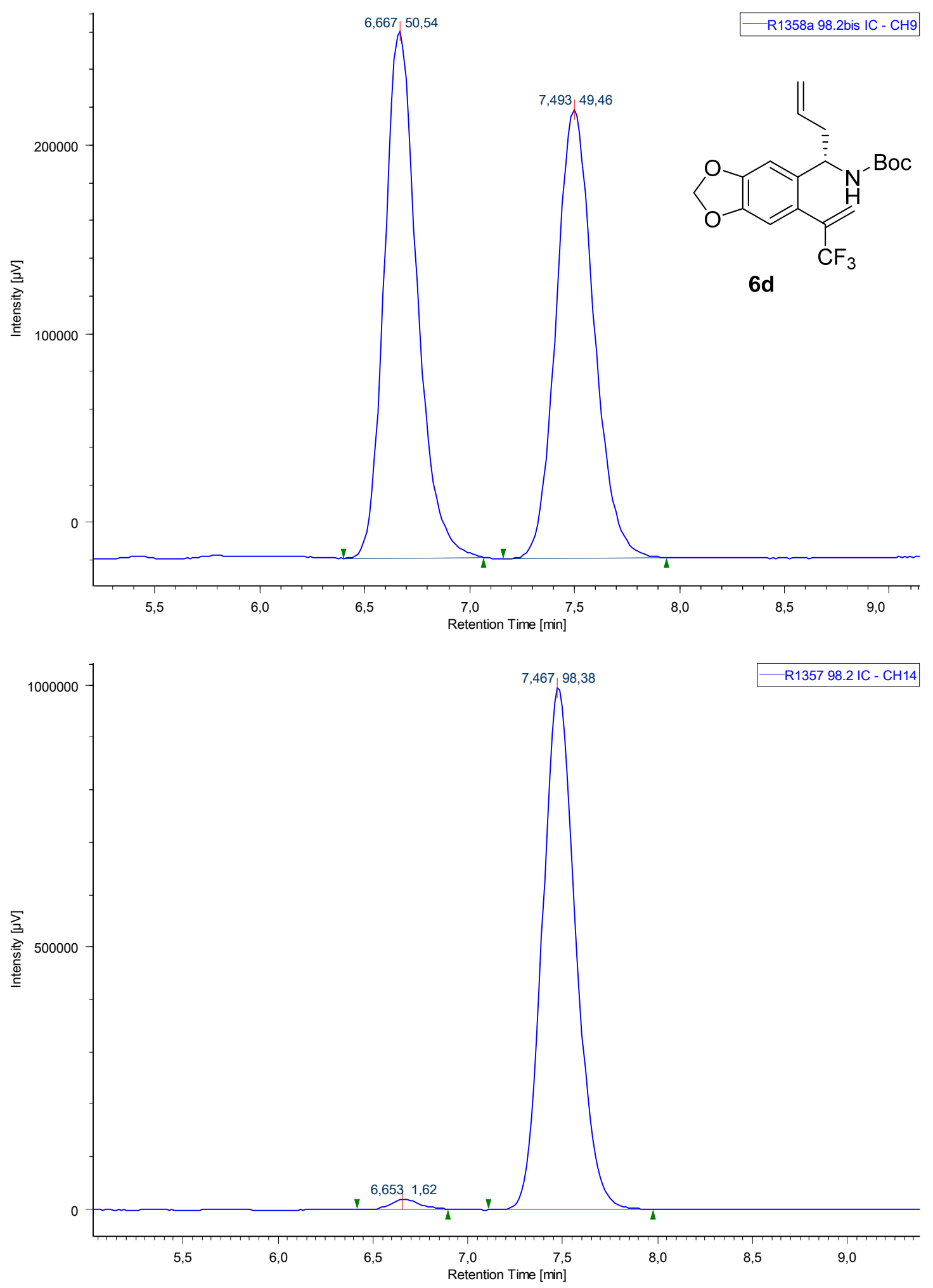

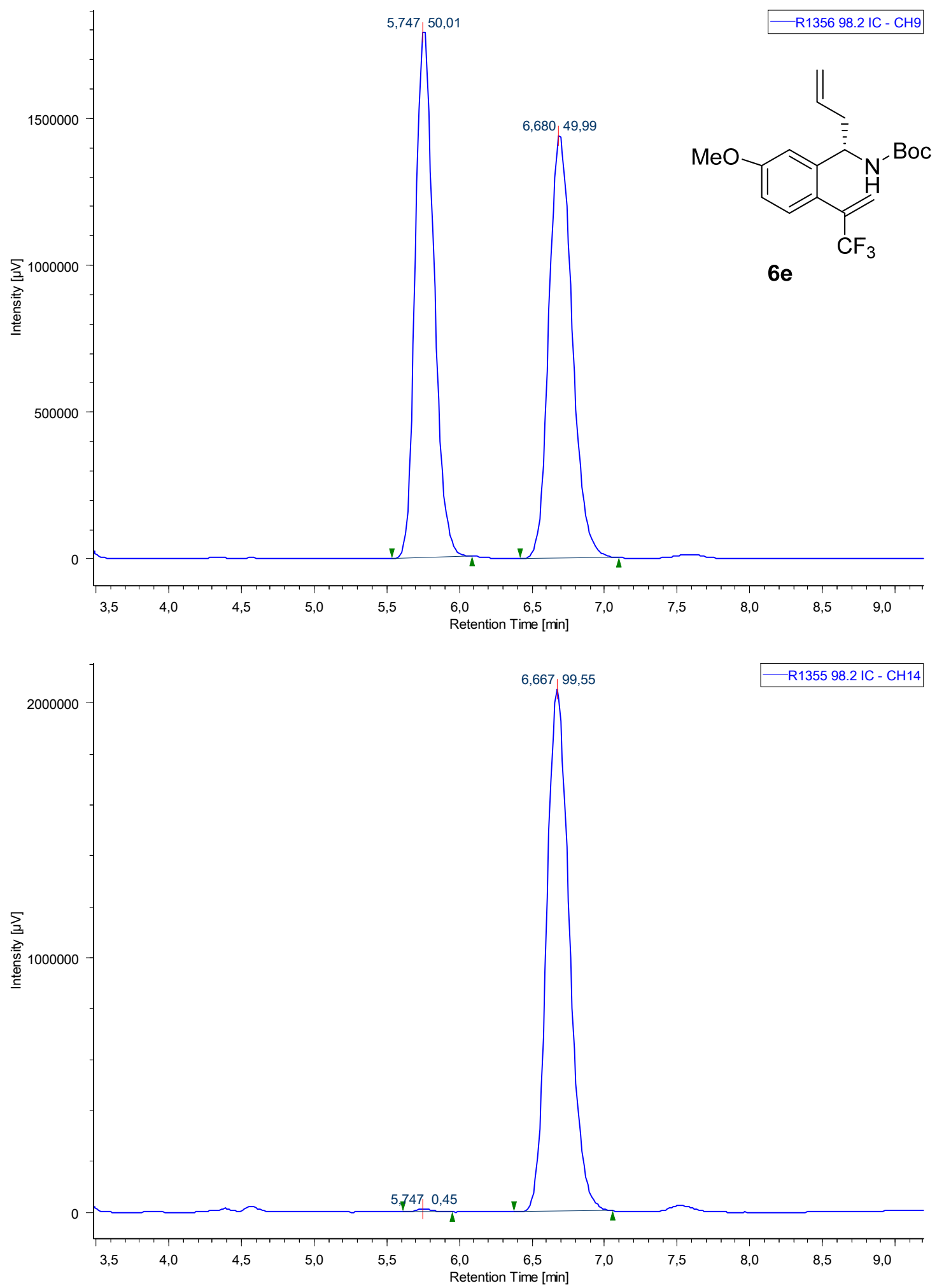

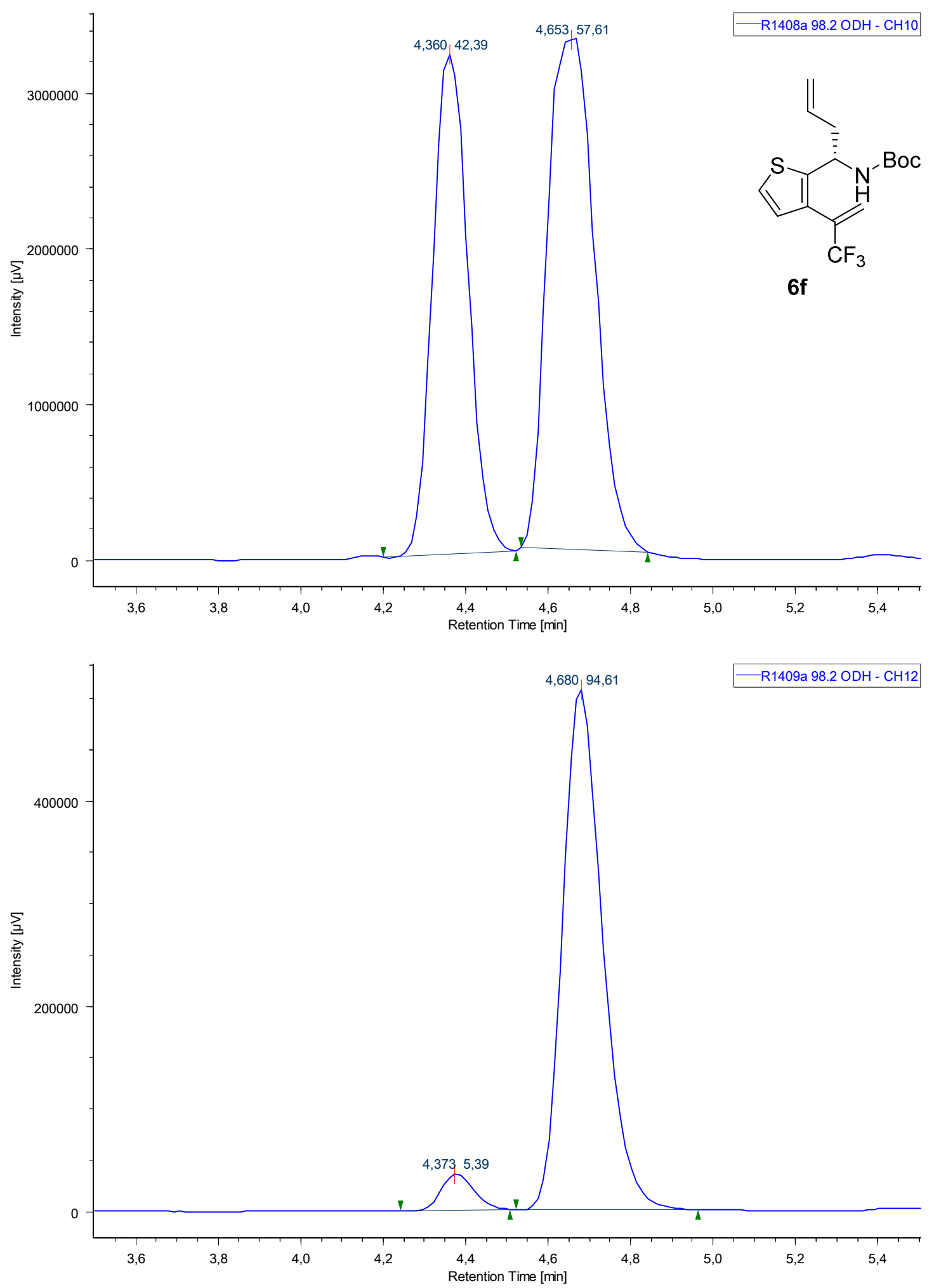

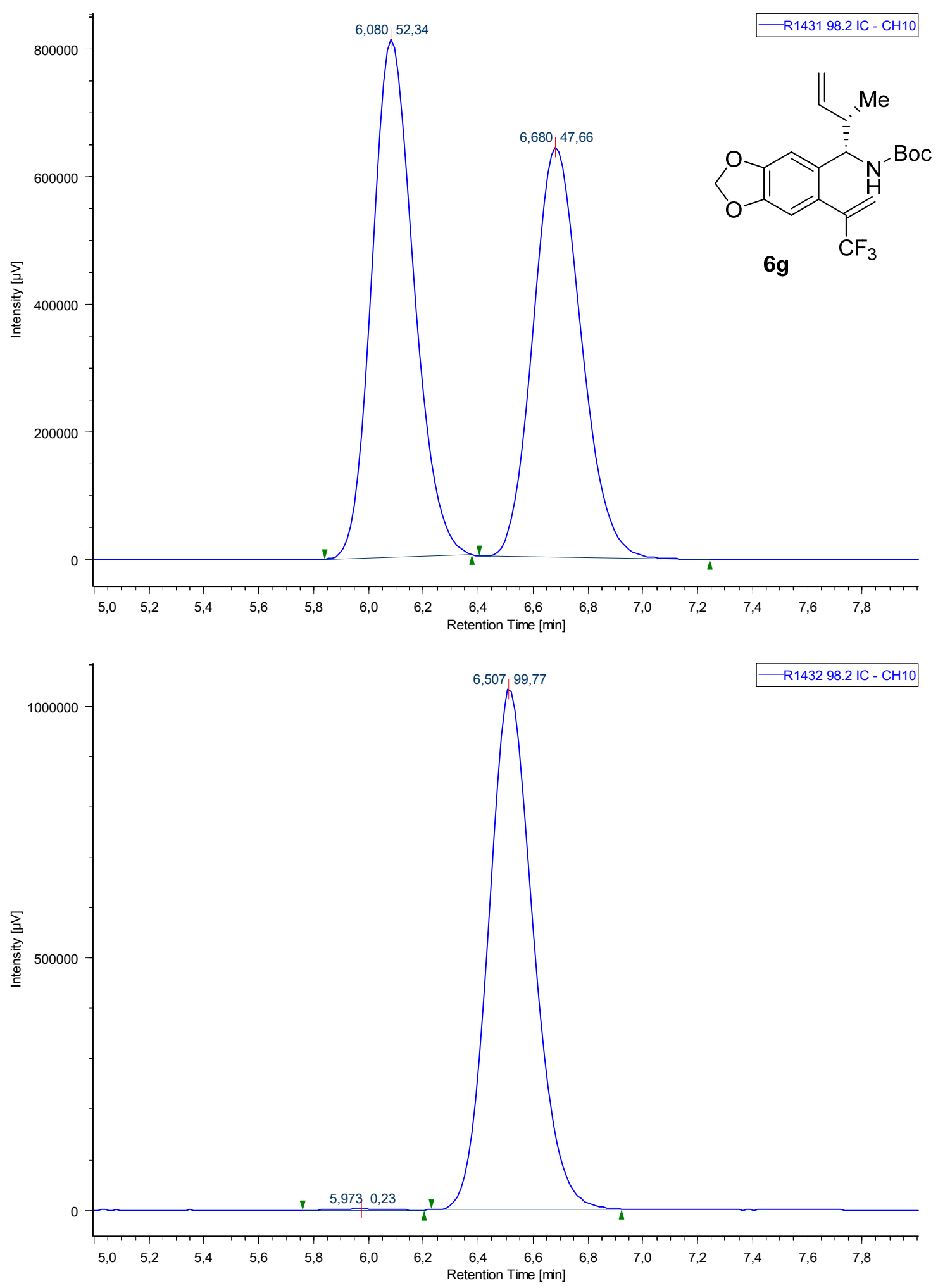

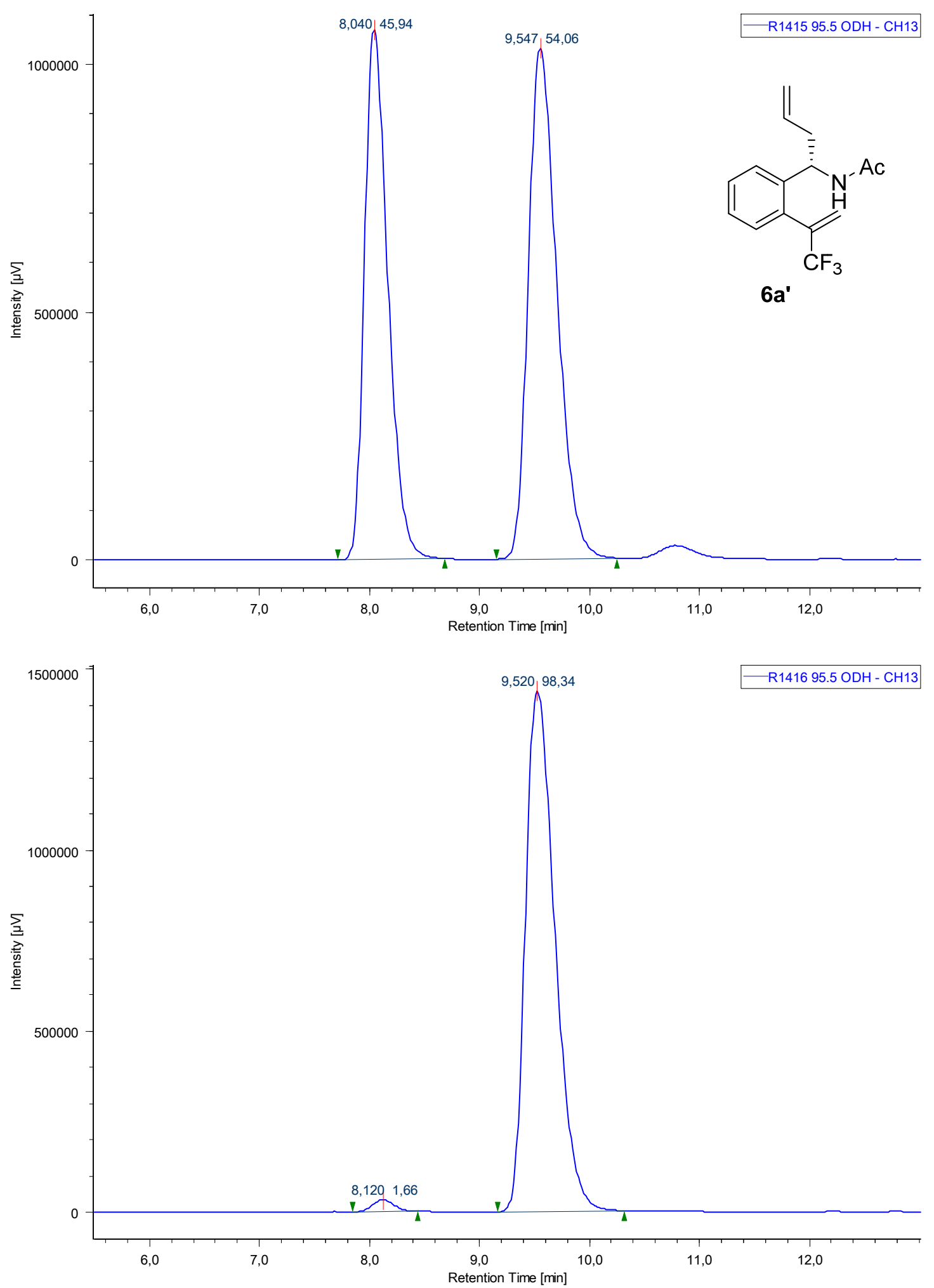

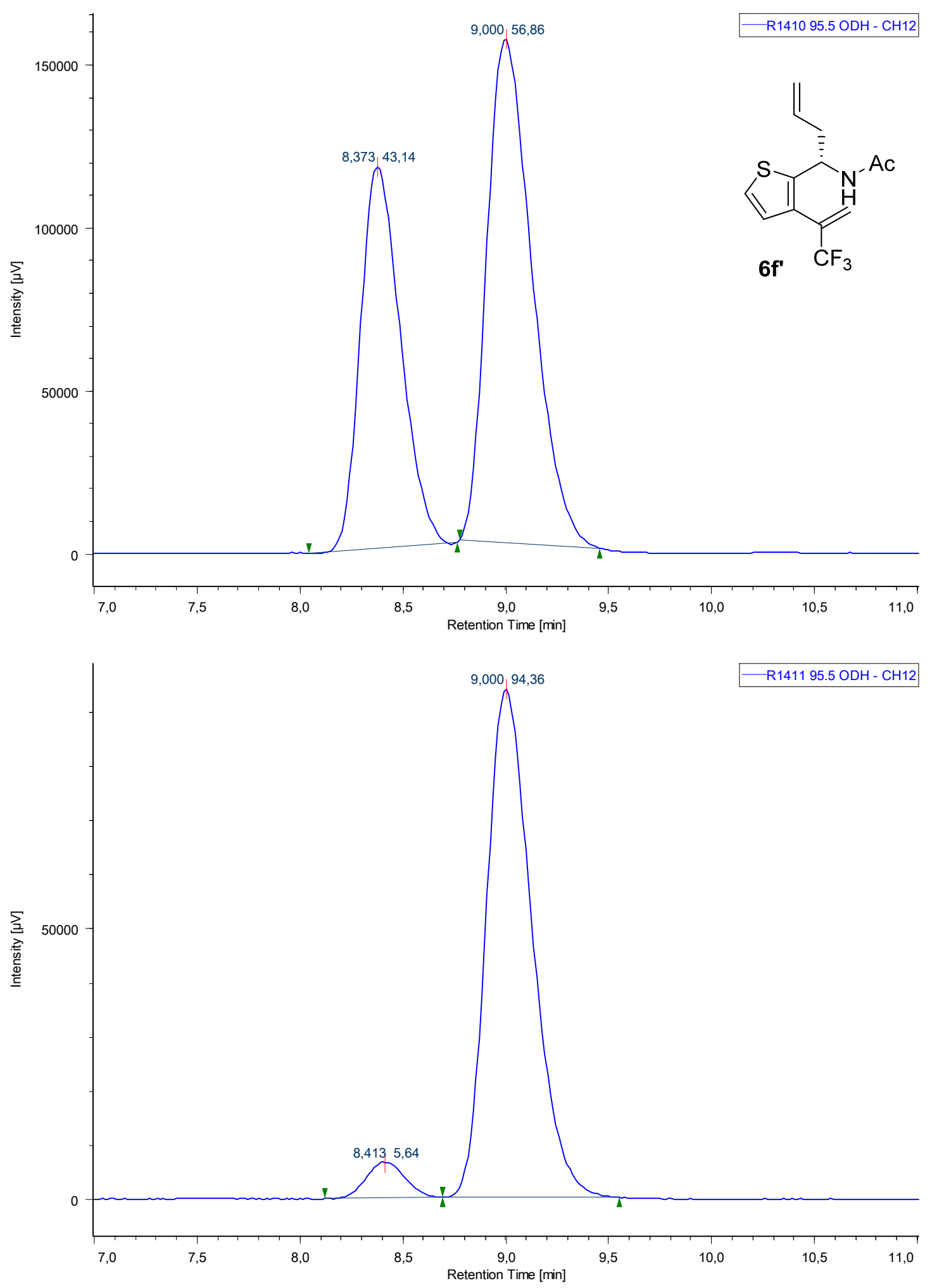

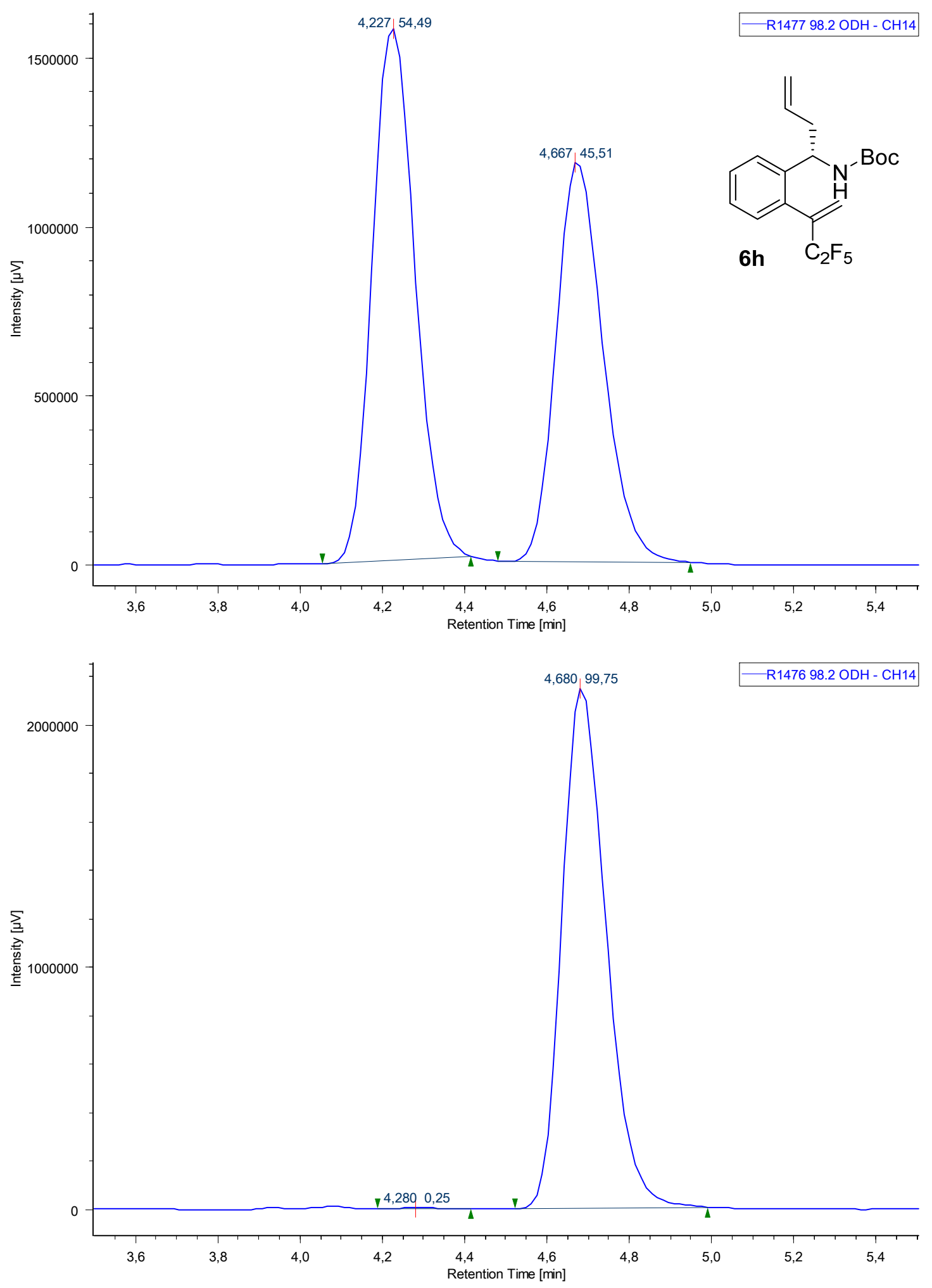

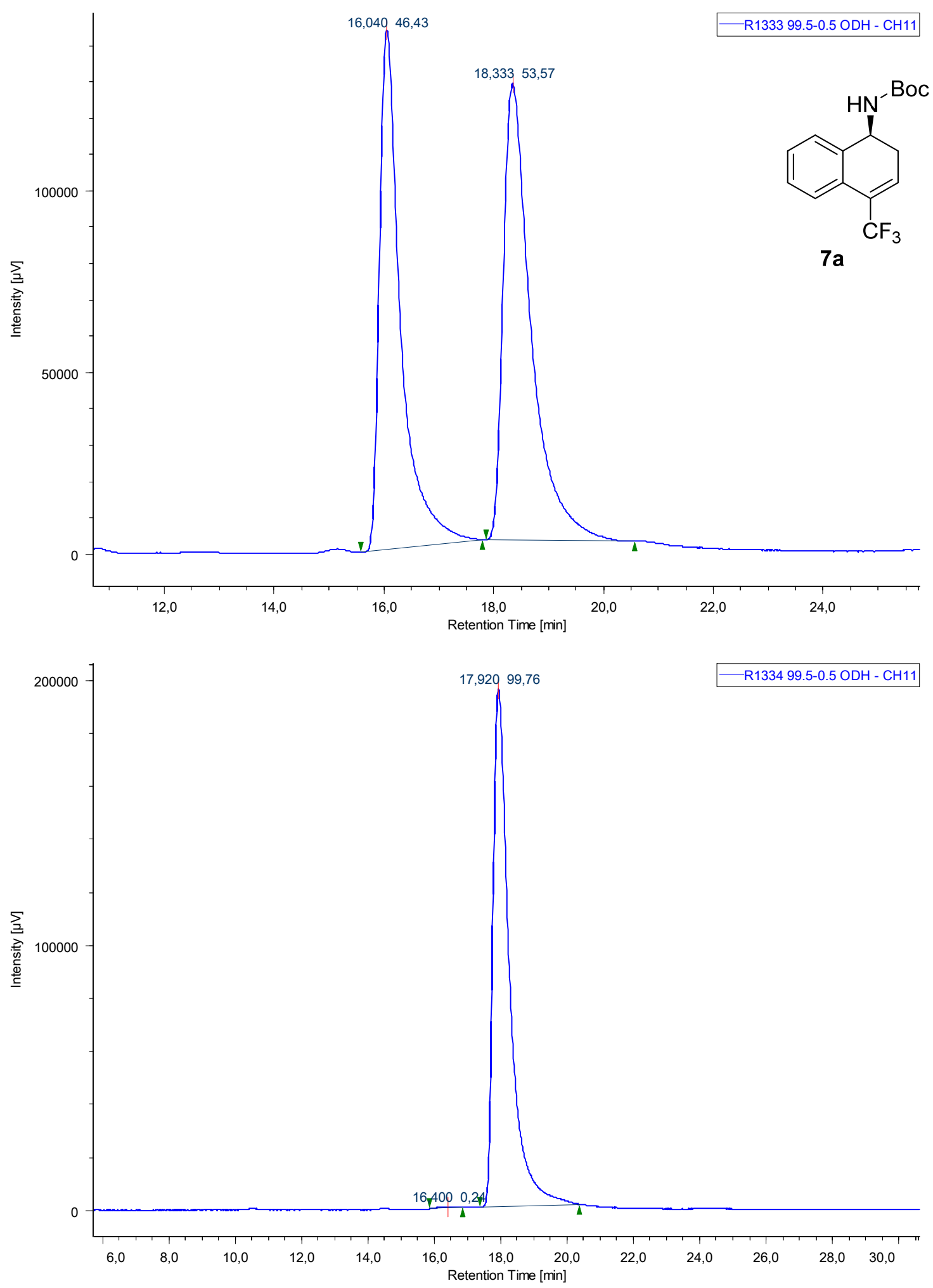

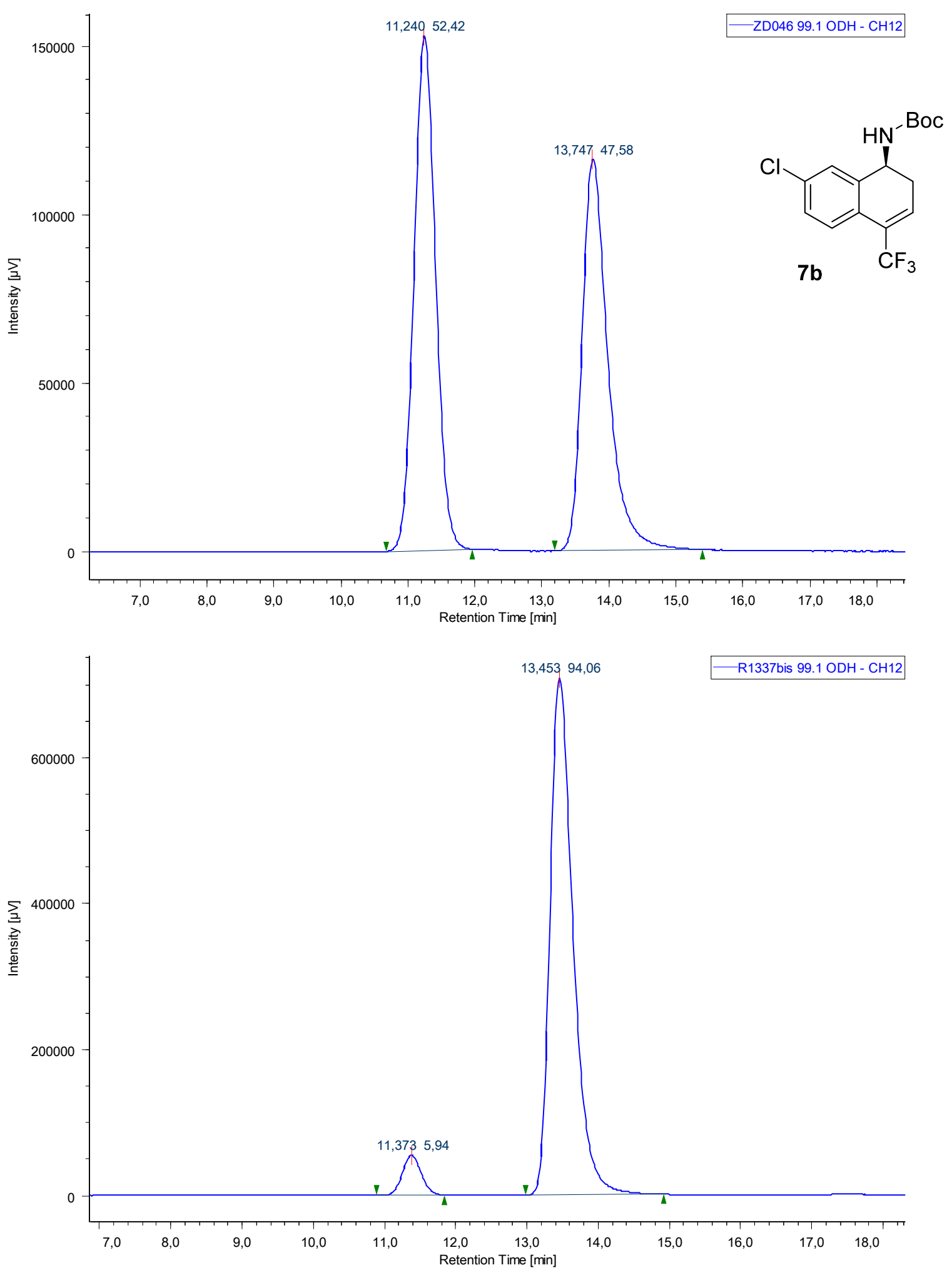

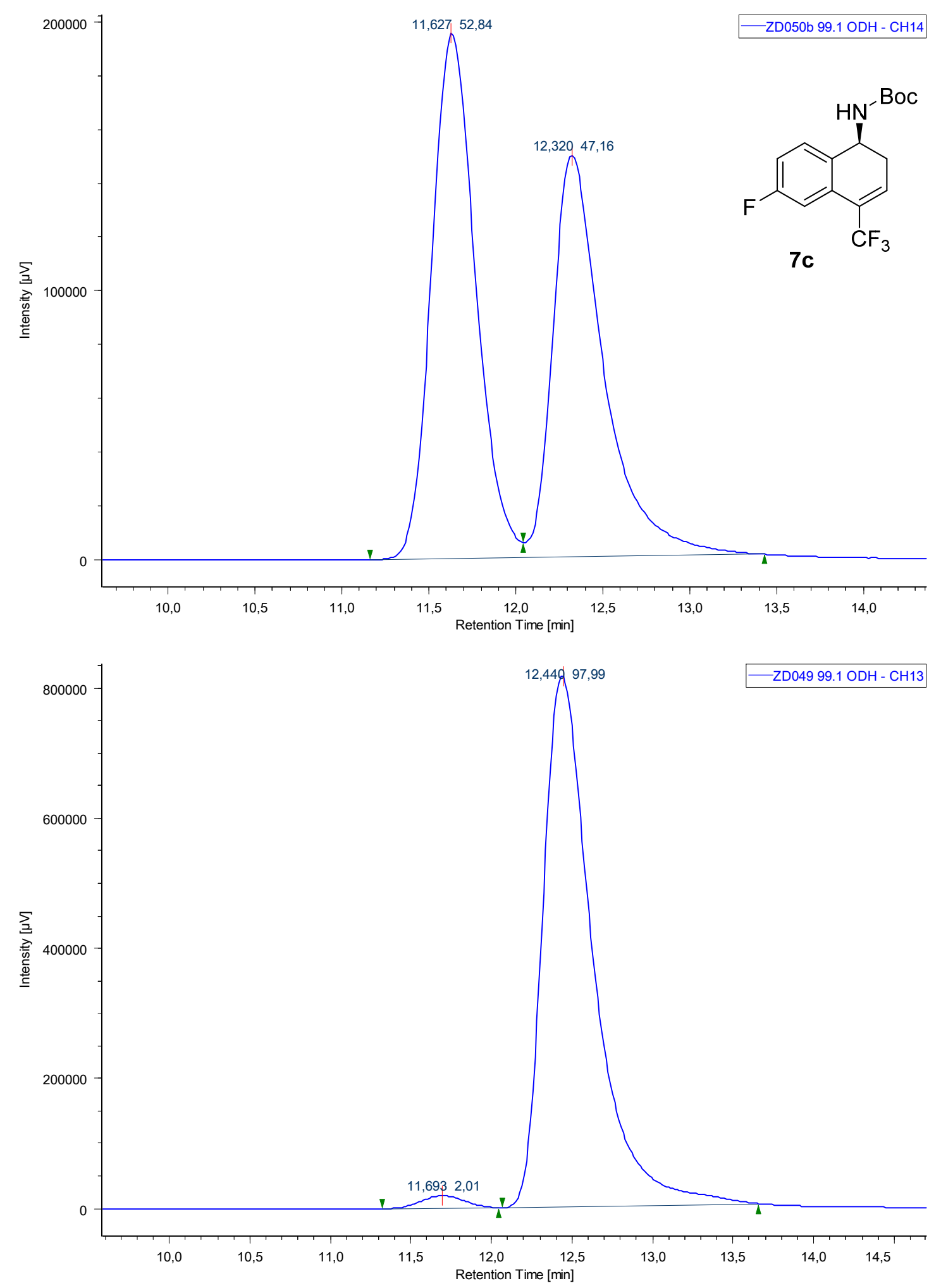

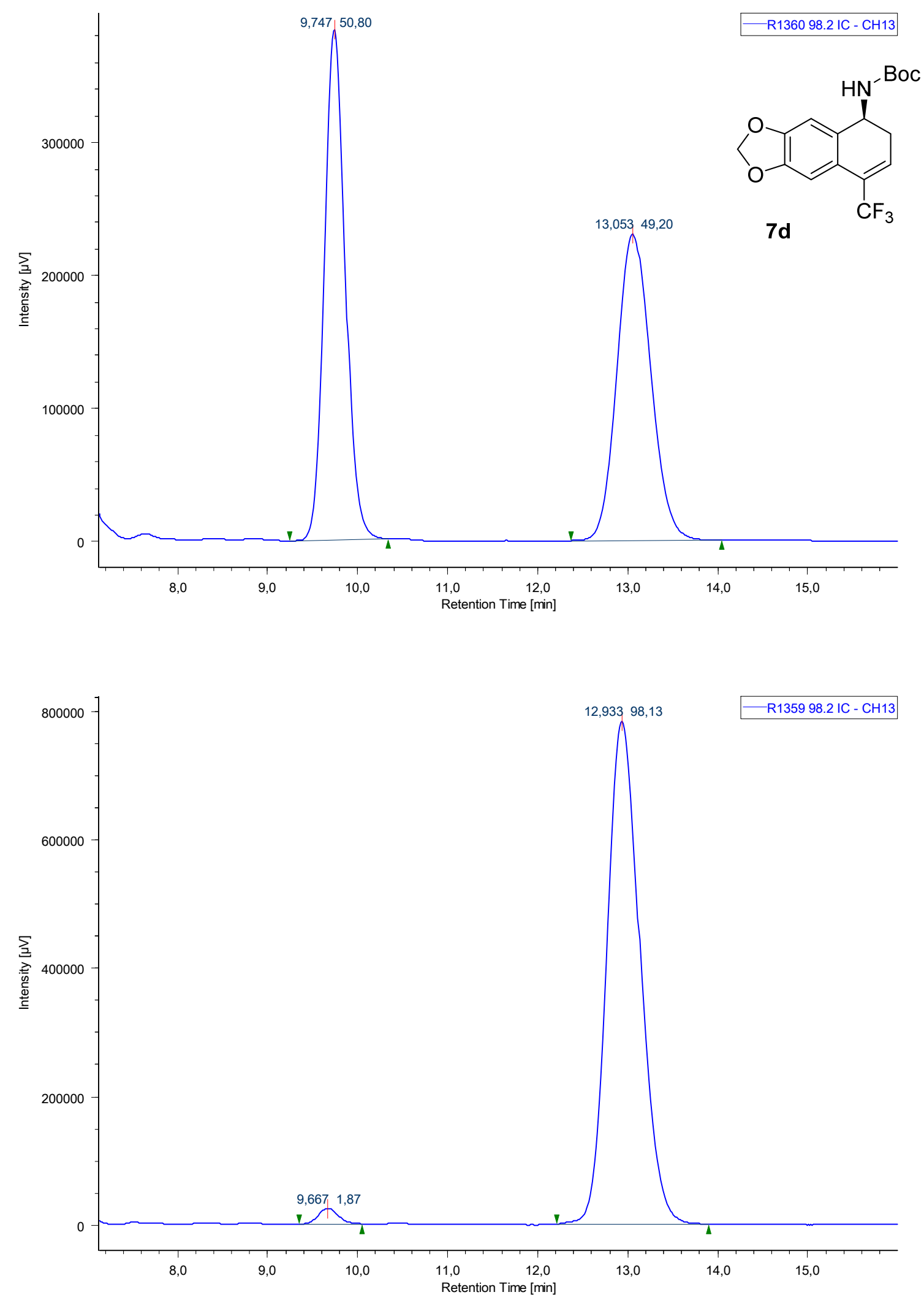

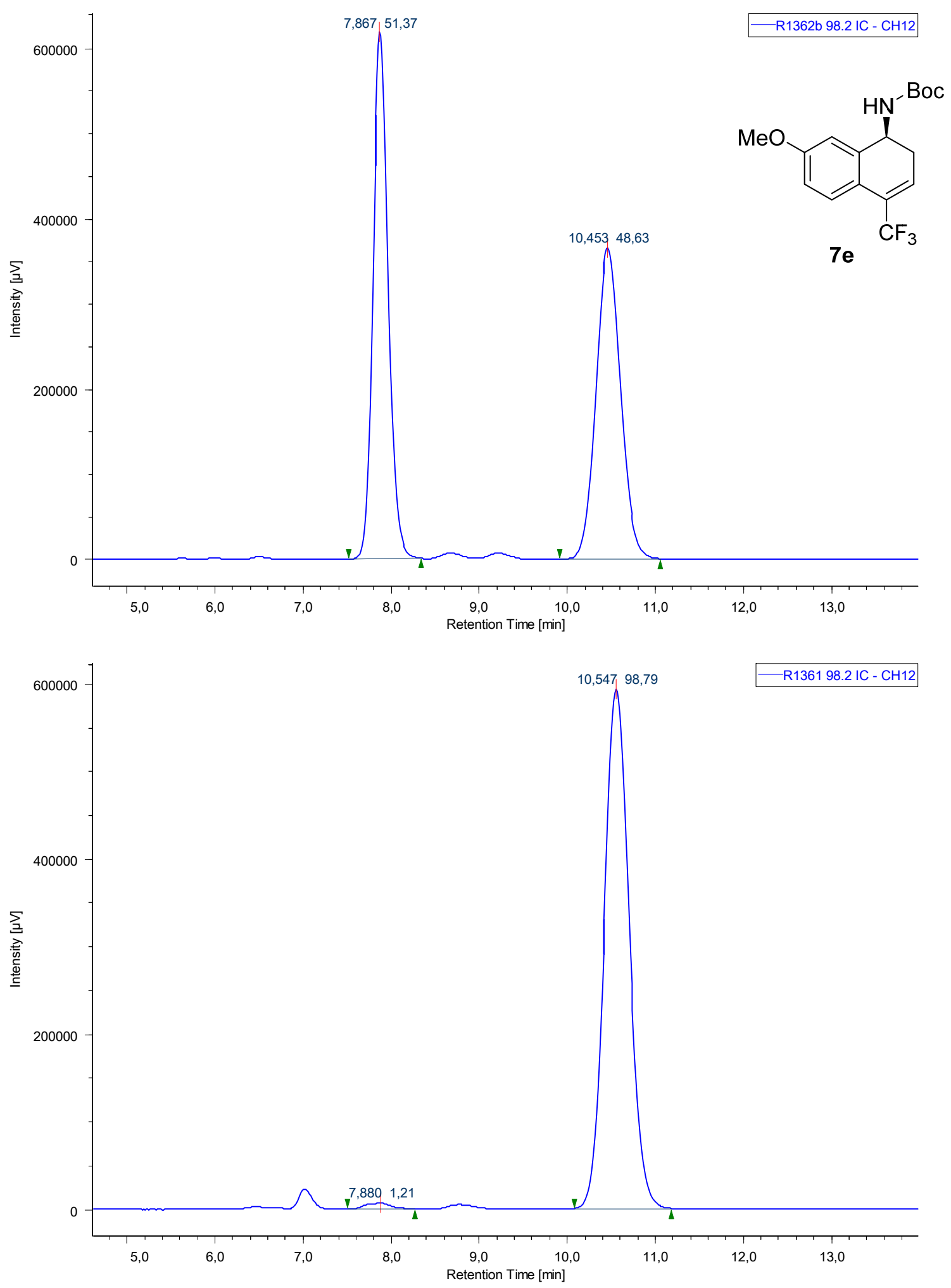

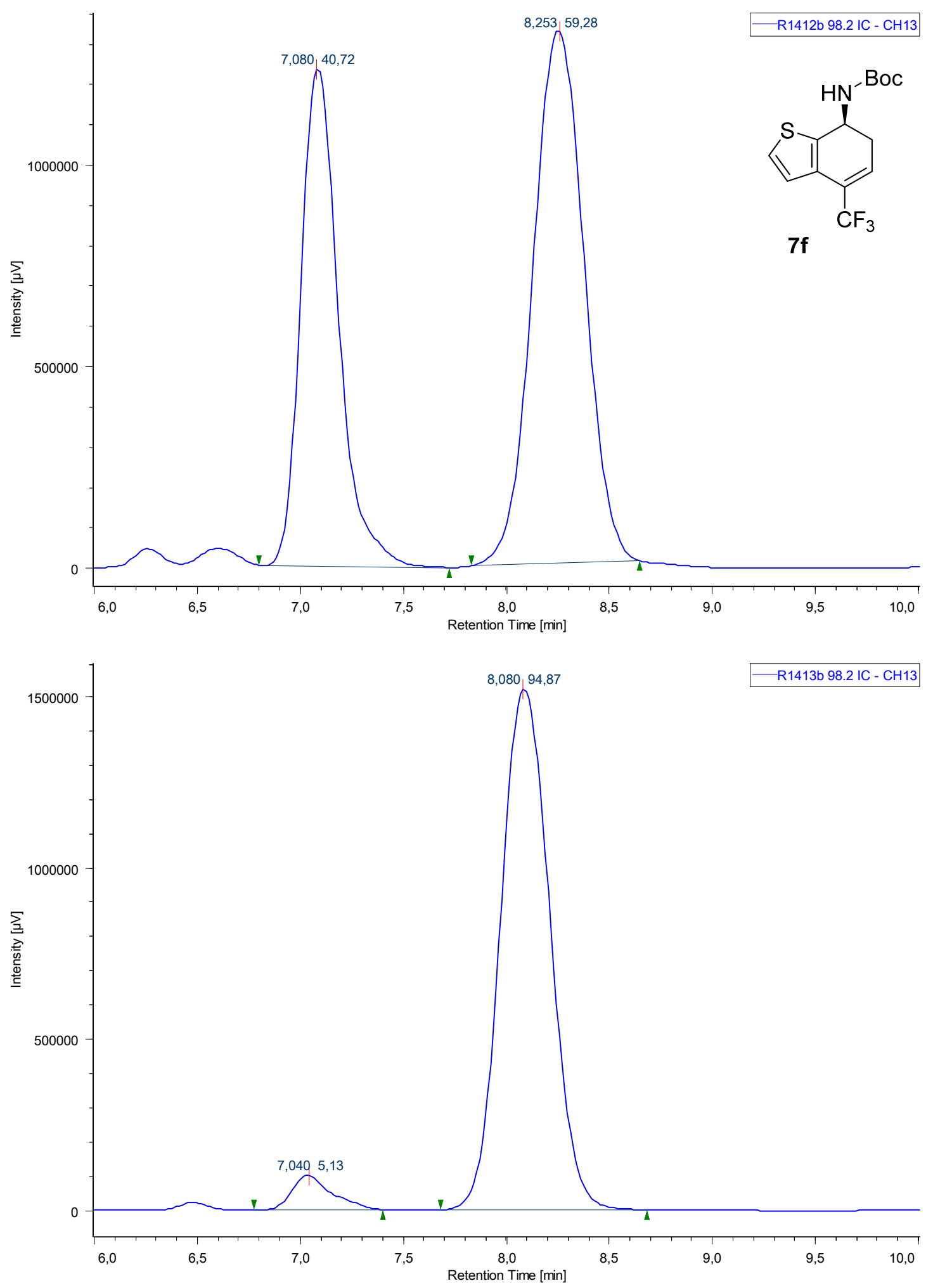

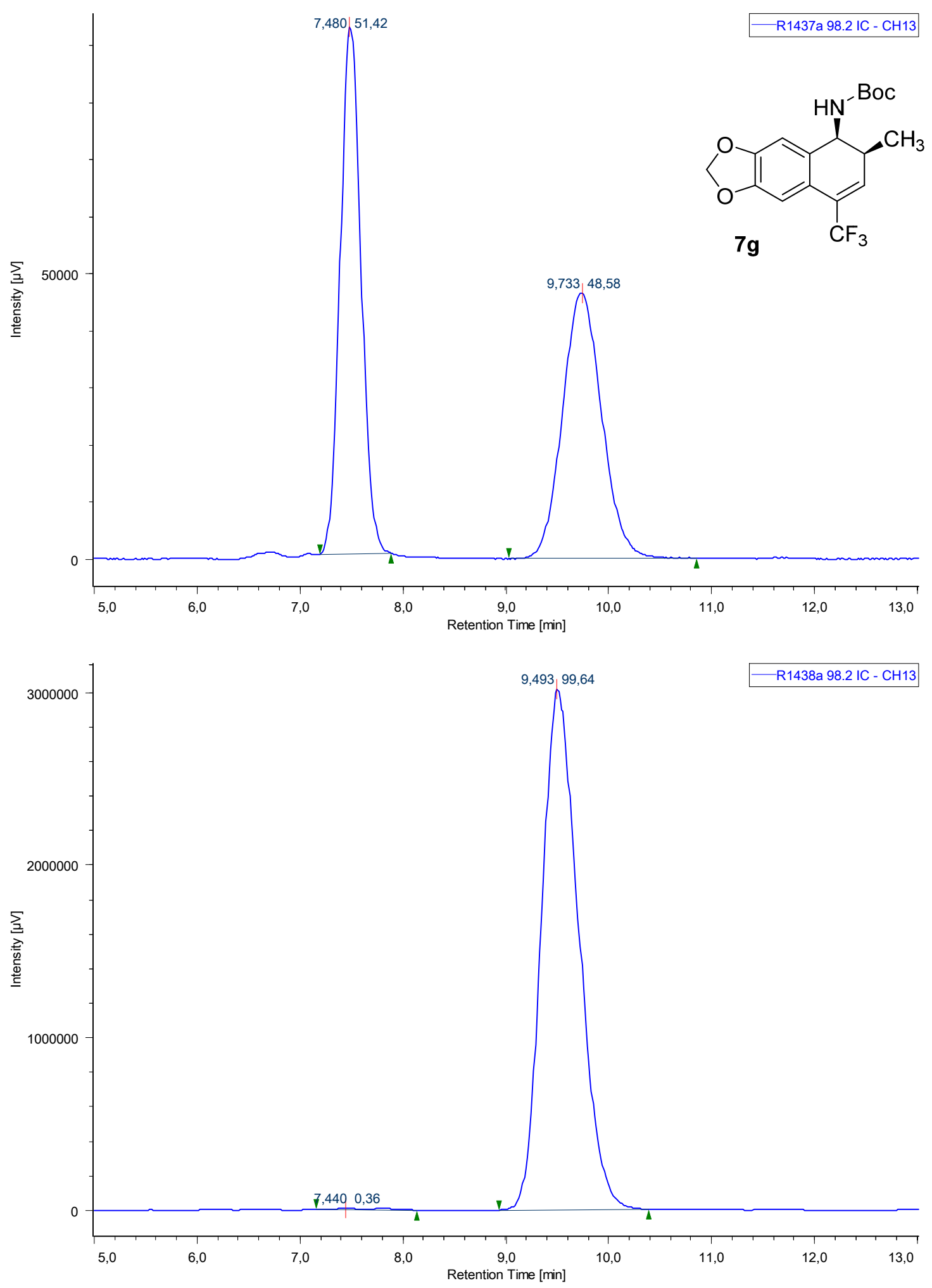

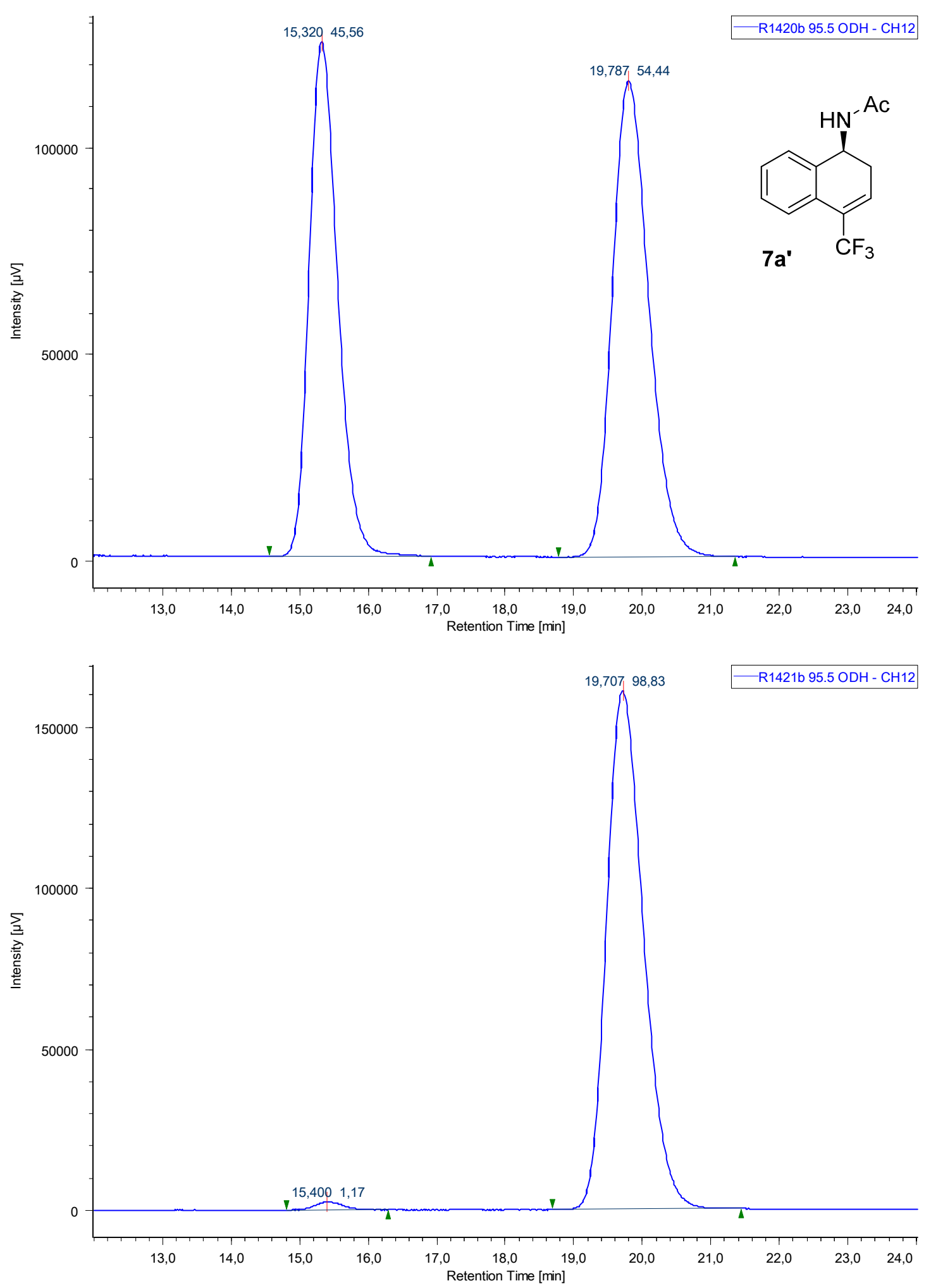

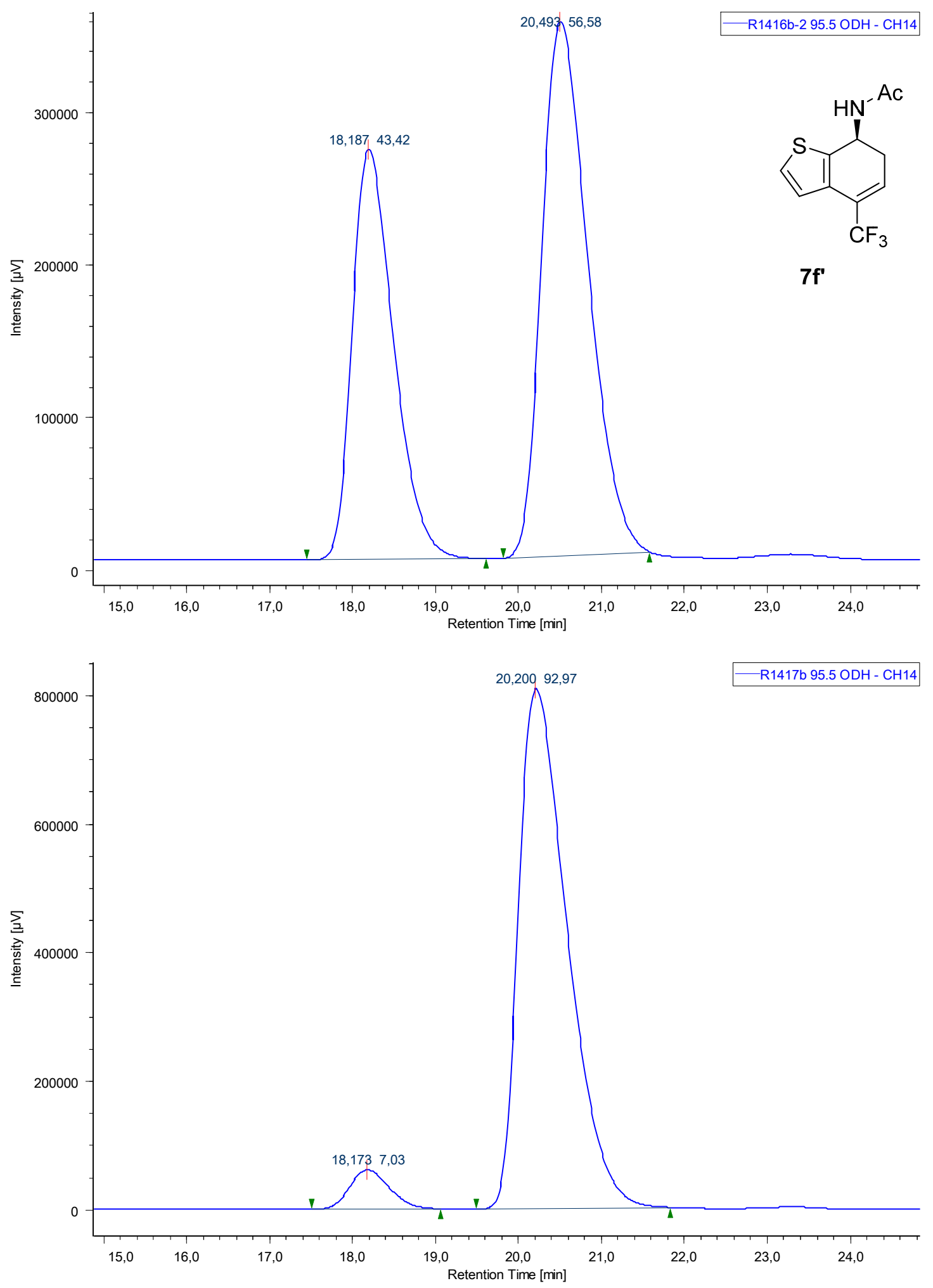

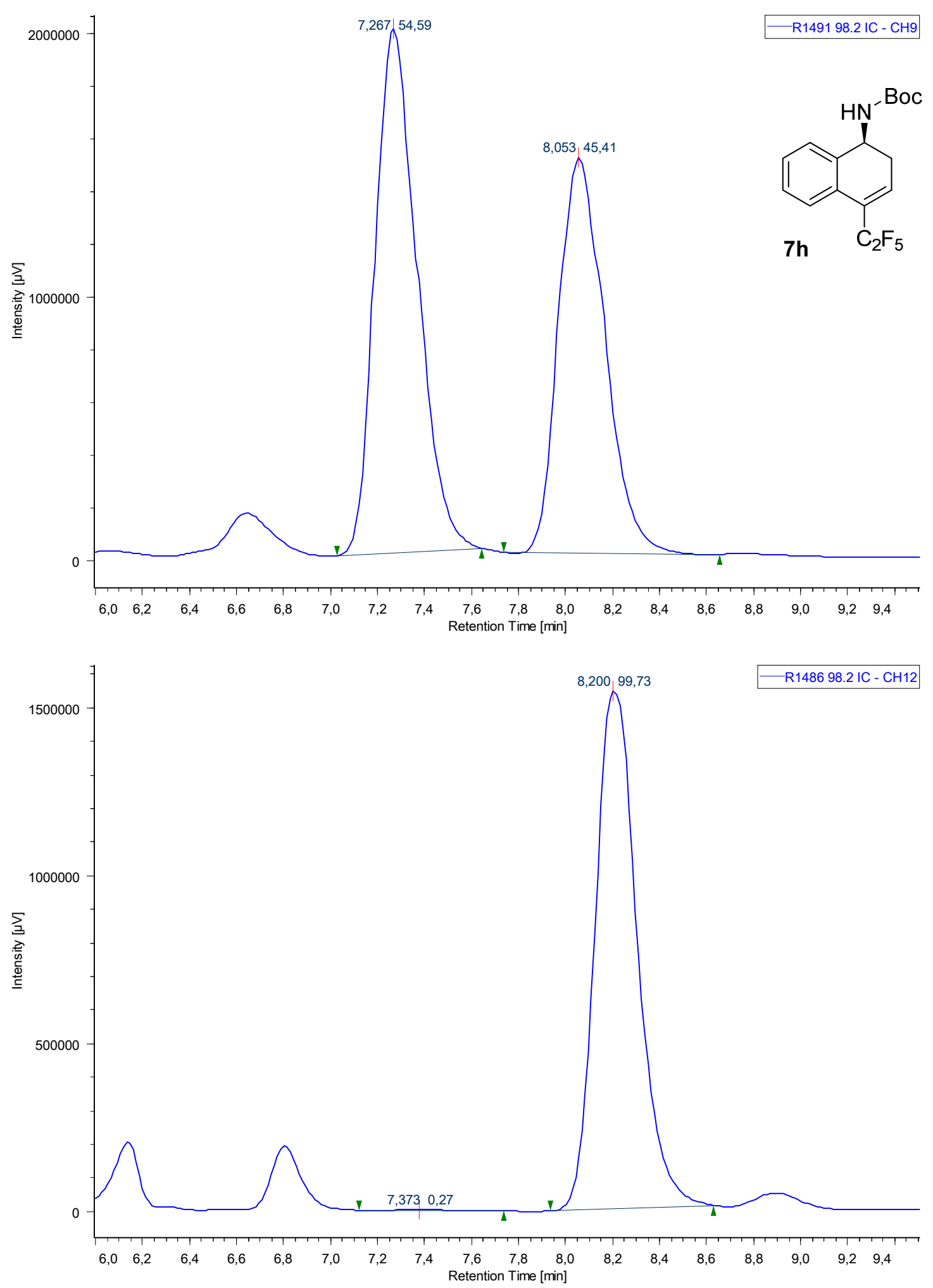


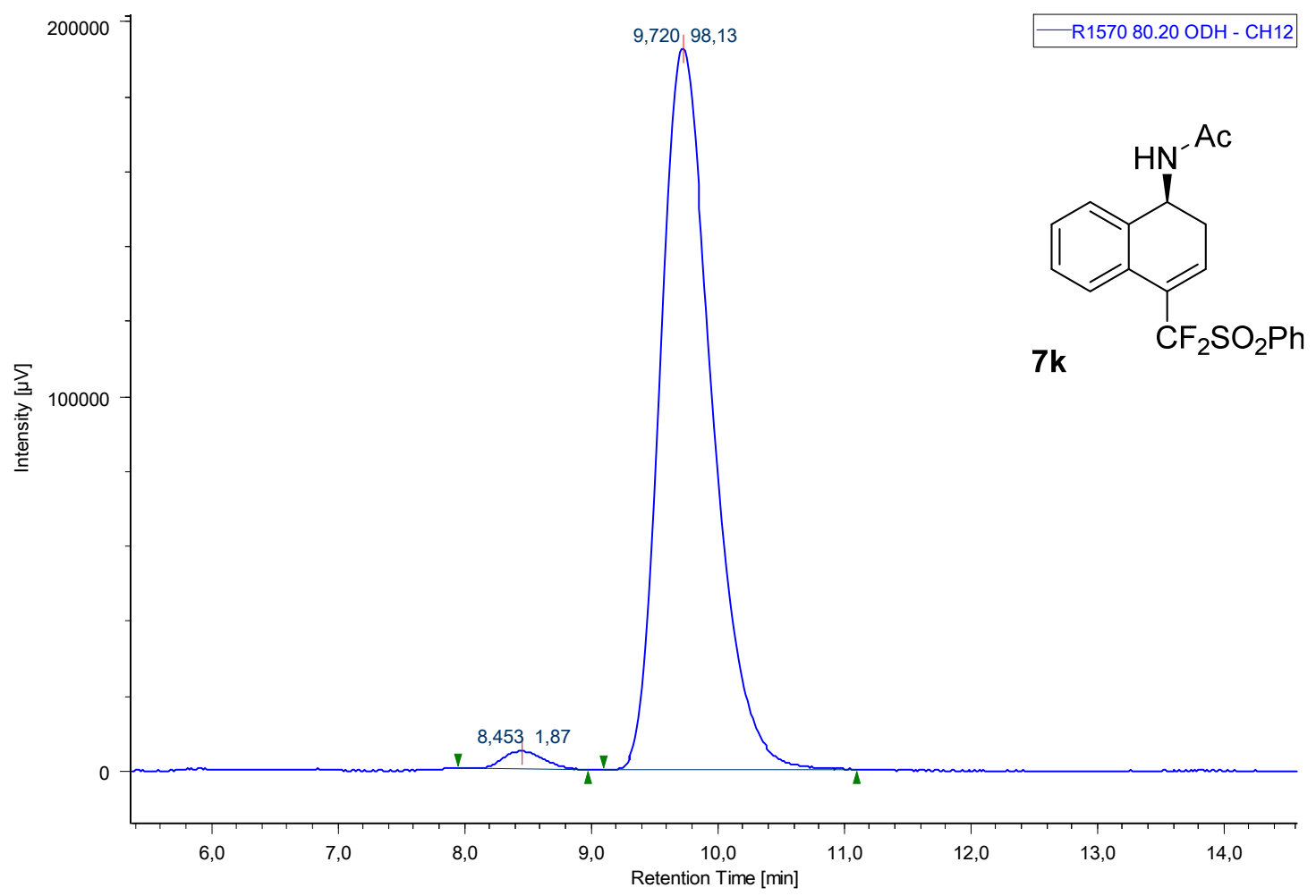

